\title{
Examination of the Feasibility for Demonstration and Use of Radioluminescent Lights for Alaskan Remote Runway Lighting
}

January 1984

Prepared for the U.S. Department of Energy under Contract DE-SC06-83RL 10312 with the State of Alaska, Department of Transportation and Public Facilities, Division of Planning, Research Section, and Contract DE-AC06-76RLO 1830 with Pacific Northwest Laboratory

Pacific Northwest Laboratory Operated for the U.S. Department of Energy by Battelle Memorial Institute 


\title{
DISCLAIMER
}

This report was prepared as an account of work sponsored by an agency of the United States Government. Neither the United States Government nor any agency thereof, nor any of their employees, makes any warranty, express or implied, or assumes any legal liability or responsibility for the accuracy, completeness, or usefulness of any information, apparatus, product, or process disclosed, or represents that its use would not infringe privately owned rights. Reference herein to any specific commercial product, process, or service by trade name, trademark, manufacturer, or otherwise, does not necessarily constitute or imply its endorsement, recommendation, or favoring by the United States Government or any agency thereof. The views and opinions of authors expressed herein do not necessarily state or reflect those of the United States Government or any agency thereof.

\author{
PACIFIC NORTHWEST LABORATORY \\ operated by \\ BATTELLE \\ for the \\ UNITED STATES DEPARTMENT OF ENERGY \\ under Contract DE-AC06-76RLO 1830
}


EXAMINATION OF THE FEASIBILITY FOR DEMONSTRATION AND USE OF RADIOLUMINESCENT LIGHTS FOR ALASKAN REMOTE RUNWAY LIGHTING

\title{
FINAL REPORT
}

by

\author{
G. Jensen \\ L. Perrigo \\ PNL \\ L. Leonard \\ L. Hegdal \\ DOT\&PF \\ Work supported by \\ the U.S. Department of Energy \\ under Contract DE-SC06-83RL 10312 \\ with the State of Alaska \\ and \\ Contract DE-AC06-76RL0 1830 \\ with Pacific Northwest Laboratory \\ Operated for the U.S. Department of Energy \\ by Battelle Memorial Institute
}

\author{
January 1984 \\ Prepared for: \\ STATE OF ALASKA \\ DEPARTMENT OF TRANSPORTATION AND PUBLIC FACILITIES \\ DIVISION OF PLANNING \\ RESEARCH SECTION \\ 2301 Peger Road \\ Fairbanks, Alaska 99701-6394
}




\section{NOTICE}

The contents of this report reflect the views of the author who are responsible for the facts and the accuracy of the data presented herein. The contents do not necessarily reflect the official views or policies of the Alaska Department of Transporta* tion and Pullic facilities. This report does not constitute a standard, specification or regulation. 


\section{ACKNOWLEDGMENTS}

This report was written to address the development of radioluminescent (RL) airfield lighting at civilian airports in Alaska. For this reason, much of the development concurrently taking place for the military sector is not discussed or is oniy briefly treated. The authors wish to point out, however, that the overall development of the RL airfield lights has been and continues to be a cooperative effort of several agencies, both civilian and military. This cooperative effort is directed by the U.S. Department of Energy (DOE) Defense Byproducts Production and Utilization Program with the advice of a Technical Working Group. We wish to thank the individuals which have contributed so much to this team effort and specifically acknowiedge the contribution of each:

Program Manager:

Technical Working Group:
W. C. Remini, U.S. DOE, Washington, D.C.

D. R. Brown, U.S. DOE, Oak Ridge Operations Office

K. W. Haff, ORNL Project Manager

Lt. Col. L. T. Everett, Field

Demonstration Test Director

F. N. Case, ORNL Principal Investigator

T. Hardy, USAF Project Manager

J. A. Tompkins, ORNL Co-Principal I nves ti gator

L. E. Leonard, State of Alaska Project Manager

G. A. Jensen, PNL. Project Manager

In addition, the authors wish to acknowledge the yeoman service performed by the following individuals without whose efforts this project would never have progressed at such a rapid rate:

Co1. R. E. Hodge, USAF

Maj. E. Hobbs, USAF

R. G. Moles, PNL

Capt. J. Sikes, USAF
Maj. L. Hult, USAF

W. Grimm, USAC

CWO-III R. Warenburger, North Carolina Army Air National Guard 


\section{CONTENTS}

1.0 INTROOUCTION , . . . . . . . . . . . . 1

1.1 SCOPE OF WORK . . . . . . . . . . . . 1

1.2 REPORT DRGANIZATION * * * * * * * * * * * 2

1.3 STUDY METHOOOLOGY . . . . . . . . ,

2.0 BACKGROUNO AND STATE-OF - THE-ART * * * * * * . 7

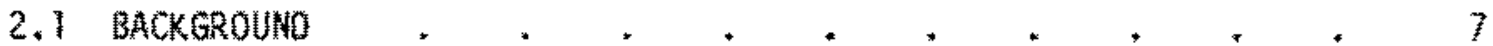

2.2 STATE-OF *THE-ART ASSESSMENT * * * * * * * 7

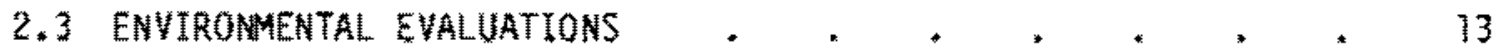

2.4 LICENSING REQUREMENTS * * * * * * * * 25

2.5 INSTITUTIONAL ISSUES AND EDUCATION . * . . . *. .31

3.0 ENGINEERING EVALIIATIONS ANO DESIGN CONSIDERATIONS . * . . 37

3.1 AIRFIELL LIGHTING RESPONSIBLLITY * * . . . * * 37

3.2 OESIGN DEVELOPMENT * . . * . * . . . . 38

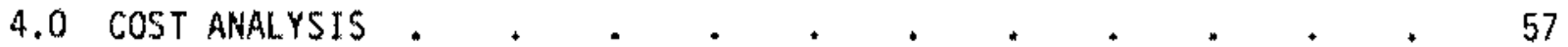

4.1 COST OF MANUFACTURE . . . * * . . . 57

4.2 MAINTENANCE * * . * . * . * , * 63

4.3 PRELIMINARY LCC ANALYSIS AND COST-BENEF IT CALCULATIONS
COMPARIAG CONVETIONAL SYSTEMS * * * * *, 65

5.0 Conclustons......++++++57

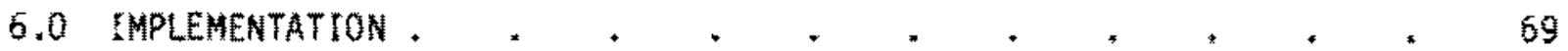

7.0 REFERENCES * * . * * *.*.*.* 71

8.0 PATENTS * * * . . . * . * * * 75

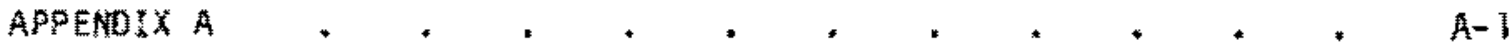

APPENDIX B * * + * * * * * * * B-1

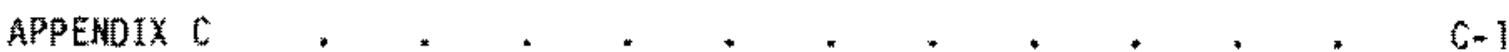

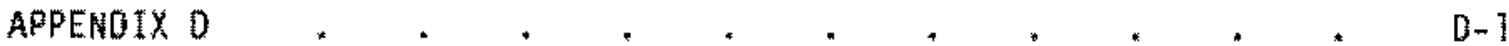

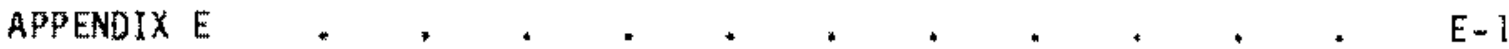

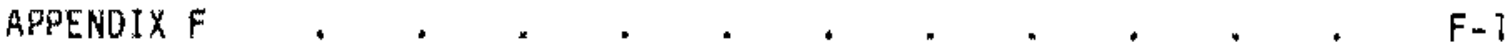

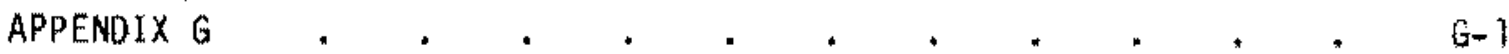

APPENDIXH 
l 


\section{TABLES}

2.1 Possible I sotopes for Self-Powered 111 uminators and Their

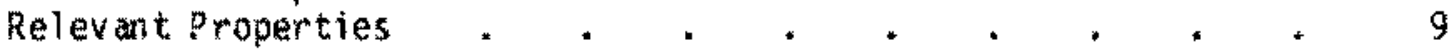

2.2 Existing or Experimental Uses for Isotopes in Self-powered Lights 9

2.3 Computer Dose Commitments Due to Inhalation of Tritun Following a Major Accident * + * * * * * * * 26

4.1 Cost Table . . . . . . . . . . . 64 
3

$*$

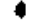




\section{FIGURES}

1.) Work Path Diagram . . . . . . . . . . 5

2.1 Technical Principle (cas-Tritium or Krypton-Bj, Solid -

Promethiun) * * * * * * * * 8

2.2 Integral Air Concentrations on Centerline of Runway . . . 20

2.3 Integral Air Concentrations $20^{\circ}$ Off Centerline of Runway * . 21

2.4 Integral Air Concentrations $45^{\circ}$ off Centerline of Runay , * 22

2.5 Integral Air Concentrations $60^{\circ}$ off Centerline of Runway . . 23

2.6 Integral Air Concentrations $90^{\circ}$ Off Centerline of Runway * . 24

3.1 R! Wand, . . . . . . . . . . 39

3.2 Bogue Field RL Lights and Fixture * * . * * 4

3.3 Prototype Light Flxture . . * * * . 42

3.4 R. Runway Lighting Configuration as used "Brinfrost 83 and

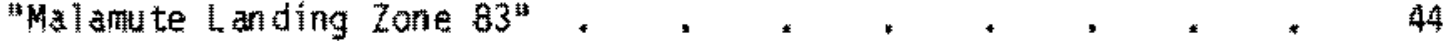

3.5 RL Yisual Approach 5lope Indicator (VASI) . . . . . . . 45

3.6 Wind Direction Indicator Used at "Malamute 83" Tests . . . 47

3.7 Conceptual RL Rumway Lighting Configuration Based on MAC 55-130 49

3.8 Tritiun Tuoe for Second Generation Units * . * . . 50

3.9 Redes lgned Panels in panel Array . * * . . * * 51

3.10 Second Generation panel . . * . . . . * 53

3.11 Edge Light - Taxiway Light . . . . . . . . . 55

3.12 panel Arrays . * * . . * * . * * * 56

4.1 Military MAC 55-130 Configuration . . . . . . . 60

4.2 Civilian-Style RL Lighting System , . * . . . . 61

4.3 Minimal Civillan-Style RL Lighting system . . . . * 62 
. 
EXNINATION OF THE FEASIGILITY FOR DEMONSTRATION AHD USE OF RADIOLUMINESCEHT LIGHTS FOR ALASKAN REMOTE RUWWY LIGHTING

\subsection{INTRODUCTION}

In March 1983, the State of Alaska, Departitent of Transportation and Public Facilities (Alask DoT\&PF) authorized and funded a study by the pacific Northwest Laboratory (PML) $)^{(a)}$ to examine the feasibility for denonstration and use of radialuminescent lights (RL lights) for remote Alaskan runway lighting applications. Radioluminescent lights have been under development by the U.S. Depar tment of Energy (DOE) and the Department of Defense (DoD) for a variety of purposes. Previously, the lights have used the beta energy emisstion from tritium, krypton-85, and promethium decay to excite a phosphor to produce light for emergency and instrument lighting. Recent developments using the f sotopes tritium and krypton-85 at oak Ridge National Laboratory (ORNL) $^{(b)}$ and advanced phosphor technology have produced lights sultable for applications where more intense lifht is required, such as rimway narking. This report exanines the feasibility of such applications for rural Alaskan airports.

\section{I SCOPE OF WORK}

The scope of the work is to investigate the feasibillty of using RL lights for marking rumwas at remote Alaskan airfields. The following were the work objectives for the ffort.

- Acquire and evaluate all avallable information on RL lights for use in runwa lighting and marking

- Identify availability of plights, estimate the capital operating. and maintenance costs. Anticipate near-tern development which will affect future use of these lights in Alaska. Assess human factors including ffect on pilot night vision, public acceptance, etc.

(a) The Pacific Northwest Laboratory is operated by Batelle Memorial Institute for the U.S. Department of Energy.

(b) Oak Ridge National Laboratory is operated by Union Carbide Corporation for the U.5. Departuent of Enersy. 
- Estima te equipment and airfield lighting costs, and develop the benefits-costs relationships for using these lights in place of conventional lighting systems.

- Identify sites and siting needs for demonstration and use of the lights in Alaska.

- Develop a preliminary plan, and lights and lighting design requirements, including estimated costs for demonstrating the lights at a remote Alaskan runway site.

- Identi fy and evaluate the radiological, legal, and institutional (including regulatory) issues affecting the use of RL lights in Alaska.

- Evaluate environmental factors that affect the adaptation of this technology in the Arctic.

The work needed from PNL for the Alaska DOT\&PF was to be completed in two phases, each with several tasks. The work presented in this report covers the Phase I effort and was comprised of four tasks. These four tasks encompass Task I - State of the Art Evaluation of RL Lights, Task II - Environmental, Radiological, and Regulatory Evaluations, Task III - Engineering Evaluations, and Task IV - Demonstration Plan Development and meet the scope and objectives advanced in the previous section.

The Phase II effort of this work is to implement a demonstration and installation of RL lights at an appropriate location in Alaska. The portion defining the approximate 1 imits for the future scope of the effort is found in Section 6, Implementation. Until all factors are defined, the specific sites and siting needs for demonstration and use of the lights in Alaska cannot be completed.

\subsection{REPORT ORGANIZATION}

The various sections of this report cover the effort provided by the study's statement of work. The study methodology is briefly discussed including objectives and guidelines, information sources assessed and related project activities. This is followed by a discussion of the state-of-the-art 
for radioluminescent light development including discussions of the environmental, radiological, regulatory, institutional, and behavioral- and human-factors issues related to the use of radioluminescent lighting for aircraft marking, runway llghting, and other purposes. Other possible uses jnclude highway marking and marine navigational aids in Alaska but are not spectifically addressed in this report. The engineering evaluatons and design considerations are found in the next section, followed by a cost analysis for deploying these lights at a remote Alaskan runway to demonstrate their applicabllity in the Arctic and/or sub-Arctic environments. Finally, the study's conclusions are presented followed by a brief section dealing with issues related to inplementation of progran for lighting alaskan village and other remote airports.

\subsection{STUDY METHODOLOGY}

The mothology, objectives and milestones for this study were identified during proposal preparation and contract negotiations with the Alaska DOT \&PF. The objectives and linitations and methodology for the effort are discussed in the following paragraphs.

\subsubsection{Objectives and Limitations}

The objectives for the Phase I effort reported here are as follows:

- Acquire information to identify the state-of-themart for application of RL lights for lighting systens for remote Alaskan airfields.

- Address the environmental, radiological, licensing and related educational needs and issues for using these tevices in Alaska.

- Develop preliminary system designs and costs estinates for using RL lighting to met remote Alaskan runway I I ghting and working needs.

- Assist in the development of a preliminary program plan for denonstrating the lights in Arctic and sub-Arctic Alaska.

- Assess the behaviomal and human factors, institutional, and edcational aspects of using RL 1 ights for lighting and marking Alaskan bush runways. 
The Alaska DOT\&PF is a participant in a much larger development effort sponsored by DOE and DOD to use RL lighting to meet remote and austere lighting needs. Other contributors to the effort thus include DOE, DDE's laboratories ORNL and PNL, and various organizations within the Department of Defense. Department of Defense organizations include the North Carolina Army National Guard, the Alaskan Air Command, the Alaska Air National Guard, the U.S. Air Force Engineering and Services Center and others. Funding for the larger effort is provided by the DOE and DOD. Thus, the Alaskan effort is benefited by a large national program. Overall planning for the work is handled by a technical working group (TWG), which has membership from all organizations participating in the program. This structure imposes 1 imitations in planning, research, development, demonstration, and implementation on the individual user, that is, the Alaska DOT\&PF but allows the Alaska DDT\&PF access to a much larger body of technical input and expertise than they could obtain by a unilateral research program.

\subsubsection{Program Activities and Information Sources}

The project plan is shown in Figure 1.1. The plan was used in the proposal to inform the sponsor how PNL and Alaska DOT\&PF personnel expected to approach the effort and served as a guide for completing the work.

A brief explanation of Figure 1.1 is usefut to clarify the various activities and how they were performed. In addition, because of the ongoing nature of the larger effort, some changes in direction and milestones were necessary and will be discussed where appropriate. Information for the background and state-of-the-art assessment was drawn from literature sources, information supplied by DRNL and others conducting research on tritium lights, and manufacturer's information. All of these resources were assessed and the results are presented in Sections 2.1 and 2.2. A discussion of basic information on the chemical, physical, radiological properties of tritium, and its licensing needs were prepared and are presented in Sections 2.3 and 2.4. The environmental, radiological, and regulatory evaluations and the state-ofthe-art evaluation proceeded essentially in parallel. The information for environmental, radiological, and regulatory evaluation was obtained fron Title 10, Code of Federal Regulations, other Nuclear Regulatory Commission 


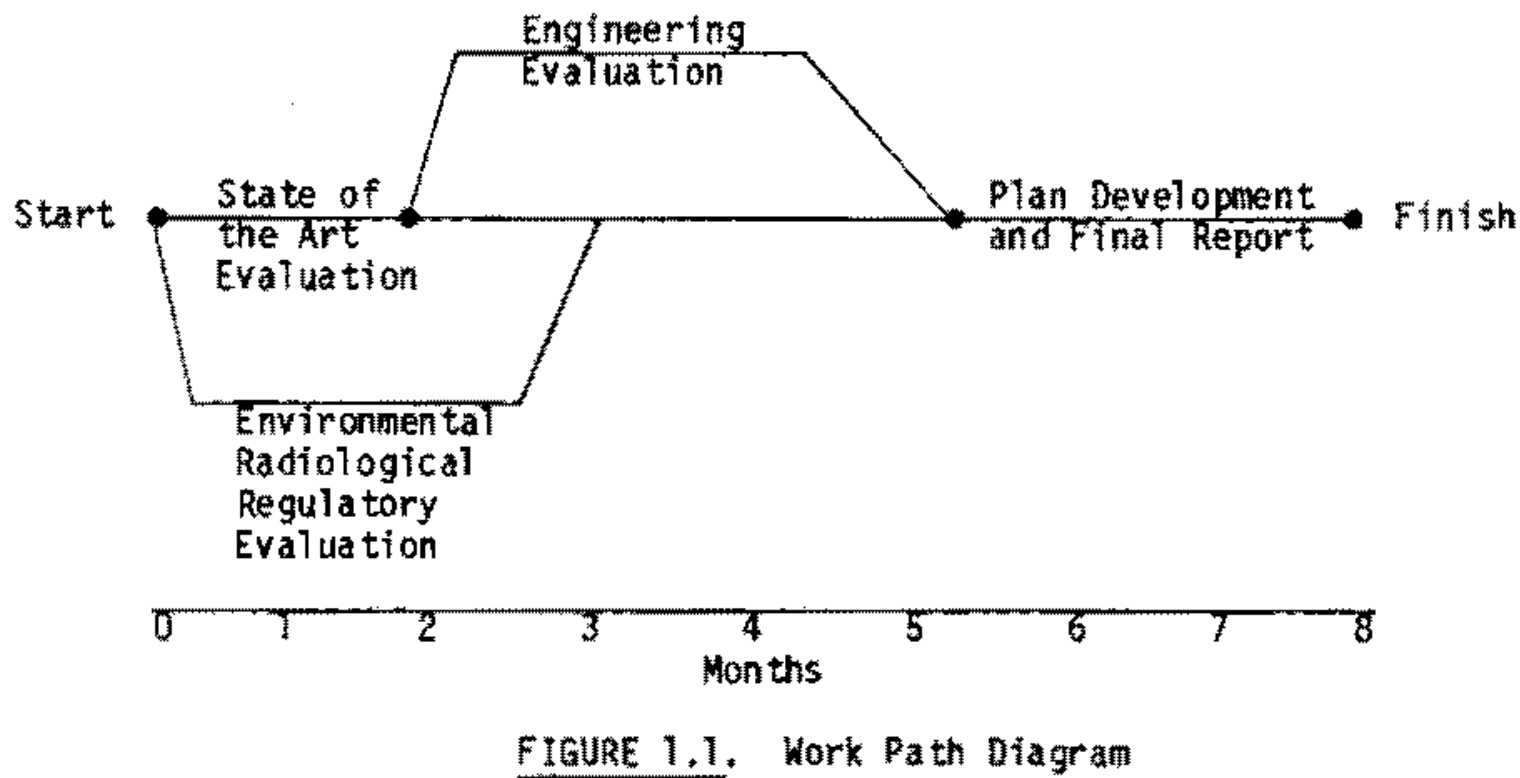

(HRC) publications, accident data, and the general literature. In addition, an evaluation of the potential exposure to tritium was completed assuming worst-case scenarios. Institutional issues, educational needs, and neded behavioral and human-factors data were addressed using inputs similar to those identified earlier and are presented in section 2.5. Engineering aluations and the design consterations discussed in Section 3 were completed in severa] iterations. This was necessary because of the continuing nature of the larger effort where major modifications to the lights, lighting fixtures, and runway-light configurations were being completed and tested. The design show in Section 3 is based on the latest technology available as applied to a 3000-foot-long rural Alaskan runway. This design will be tested and nodfied as required at central, Alaska, during the winter of 1983-ga. A cost analysis is developed in Section 4. A denonstration plan which sumarizes the work to be done at Central, Alaska, and Alaska Dotapf participation in the overall program sponsored by DOE and DOD is found in the overall DOD, DOE test plan containing the DOTsPF test plan, Appendix $A$. 
.

. 


\subsection{BACKGROUNO AND STATE-OF-THE-ART}

The work covered in this section includes the Task I and Task II effort. Included are a brief background discussion, the state-of-the-art for radio1 uminescent light development, environmental issues, licensing requirements, and radiological protection needs and assessments.

\subsection{BACKGROUND}

The Alaska Department of Transportation and Public Facilities (DOT\&PF) is working to provide airport lighting and marking systens to rural comnunities throughout Alaska. $(1,2,3)$ The application of radioluminescent lights as an al ternative to conventional lighting systems at these remote locations may offer reliabie, safe, low-cost options which need to be examined. In addition, the use of radioluminescent lights to improve flight safety by permanent replacement of flarepots or lanterns when used by air taxi operations under Part 135 of the FAA regulations for night operations at renote airfields, could reduce insurance and other aperating costs by extending operating time, reducing accident rates, and promoting more efficient use of aircraft. These reductions in costs, improved service, and flight safety, when passed on to the local level, can enhance the quality of life in the bush comunities.

\subsection{STATE-OF-THE-ART ASSESSMENT}

The use of radiation from radioisotopes to excite phosphors that, in turn, emit visible light has been known for many years. ${ }^{(4-15)}$ An example of this was the use of radium mixed with a binder and zinc sulfide phosphor painted on watch dials for self illumination. Since radium is high in cost and represents a serious heal th hazard to persons exposed to it, its use is now prohibited. Another isotope, tritium, has replaced radium to produce the

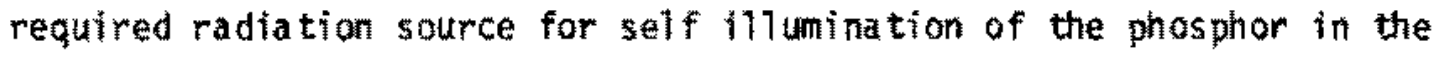
comercial sector.

In principle, beta particles (electrons) are produced by the selected isotope during its decay to form another element. These electrons strike a 
phosphorescent material, such as zinc sulfide, which contains a small quantity of impurity, such as copper, silver, or cadmitum, and are absorbed. Light is produced when the energy from this absorption is reieased, Figure 2.1. Other forms of radiation can also be produced during the decay process. These include al pha particles and gama rays. Alpha particles are hellum nuclei, which are emitted at high velocity. Gamma rays are a fom of electromagnetic radiation similar to x-rays, but have a higher frequency, greater penetrating power, and increased damage to living tissue. Thus, if an isotape is to have a practical value as an energy source for self-powered lights, it should have the following characteristics:

- a relatively long hal - life,

- not emit al pha particles ar gama rays, or be easily shielded.

- produce a stable daughter, e.g., nonradíactive isotope,

- be non-toxic chemically or radiologically, and

- have a modest or low cost.

Possible isotopes that could meet these requirments are listed in Tabie 2.1. Existing or experimental applications of radioactive fsotopes for lighting purposes are shown in Table 2.2. Krypton-85 and promethium-147 have only been

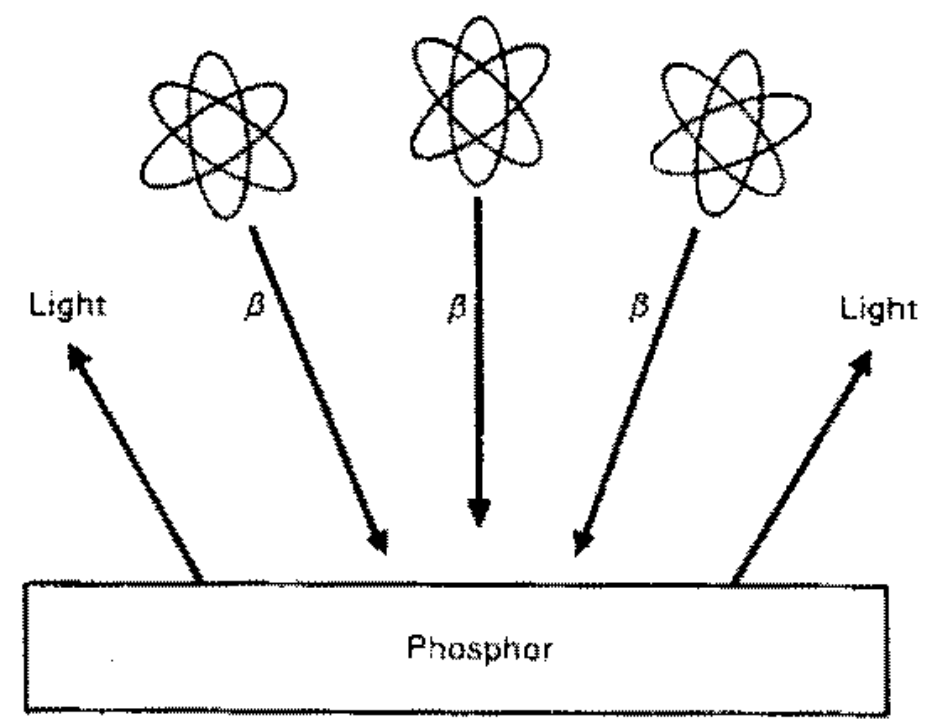

FIGURE 2.1. Technical Principle (Gas-Trittum or Krypton-85, Solid - Promethium) 
TABLE 2,1. Possible Isotopes for selfmpowerg, Illuminators
and Their Relevant Properties

\begin{tabular}{|c|c|c|c|c|c|c|}
\hline isototes & $\begin{array}{l}\text { Half } \\
\text { Jife } \\
\text { Lyears }\end{array}$ & $\begin{array}{l}\text { Maximum } \\
\text { beta } \\
\text { energy } \\
\text { onefy } \\
\end{array}$ & 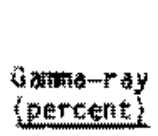 & $\begin{array}{l}\text { Tnevical } \\
\text { toxicity }\end{array}$ & $\begin{array}{l}\text { Radiologica } \\
\text { toxizeity }\end{array}$ & Kemark \\
\hline 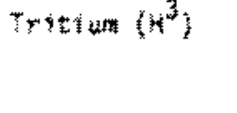 & 12.4 & 0.018 & $n$ & nil & very low & 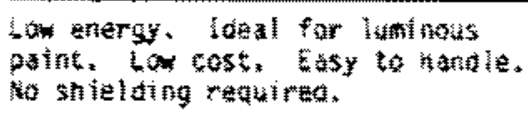 \\
\hline 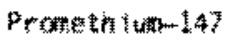 & 2.6 & 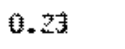 & th & nit & medtutut & Expensive. Short hat life. \\
\hline Sryotartam & 10.7 & 0.67 & 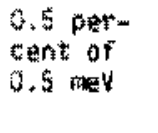 & nis & low & 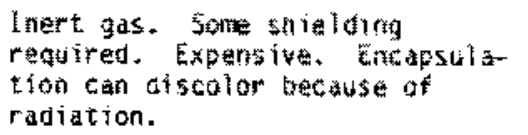 \\
\hline
\end{tabular}

\section{TABLE 2.2. Exis ting or Experimental Uses for Isotopes in Self-powered Lights $(4-15)$}

\begin{tabular}{|c|c|}
\hline isotope & Uses \\
\hline Tritium $\left(H^{3}\right)$ & $\begin{array}{l}\text { EXIT signs; public buildings and aircraft, self- } \\
\text { luminous watch dials in aircraft and instrument } \\
\text { dials, markers }\end{array}$ \\
\hline Prome thium-147 & Apollo, Moon Orbiter and land-docking lights \\
\hline Krypton-85 & $\begin{array}{l}\text { Experimental lights bullt and evaluated; A research } \\
\text { area }\end{array}$ \\
\hline
\end{tabular}

used in spectal applications and in test situations. Tritium meets all of the above requirenents and is, therefore, widely used in a variety of conmercially-available products in various applications.

Tritüun can be used in two ways. First, it can be chemically incorporated into strene and other organtc binders to produce luminescent paints. These paints have been used for wath and aircraft dal llumination, inine fleld ma rking, gunsight illumination, and other purposes. Second, tritum gas can be encapsulated in a glast tube or container coated on the inside with a zinc sulfide phosphor. Uses for this type of $1 \mathrm{ight}$ source include EXIT and other self-powered warning signs for buildings, aircraft, and light standards in the photographic industry. For example, tritium lights containing fron to 30 curies of tritium have been used on comerclal aircraft and in energency lights (EXT signs, etc.) since the mid-1960s. $(6,7,8)$ primary advantages of radioliminescent lights in existing applications are: 
- They require no external source of power, thus are not subject to power failure or interruption.

- They do not burn out or require wiring; thus, are self-contained and main tenance is winind.

- Supply problems from short shelf IIfe component replacenent, such as batteries, are reduced where temporary or emergency lighting is required.

- They can function under many severe environmental conditions such as temperatures 10 wer than $-70^{\circ} \mathrm{F}$.

Thus, the technoloy is well developed for a variety of purposes. At least seven comercial companies are producing varlety of products comercially in the United States and Europe, Appendix B. These compantes were surveyed concerning the possibilithes of using RL lighting for runway lighting and marking purposes and the responses received are inciuded in this appendix.

Strong interest exists to expand this technology to millitary uses in remote, austere, and tactical applications where utillty or portable flectrical power is unavallable or difficult to obtain. Research and development incentives for this expansion have been identified and development work to provide lights meeting the needs is underway, sponsored by the Department of Defense and Department of Energy. $(18-22)$ Both have had specific objectives in wind; however, the products of this testing to meet these objectives have show that radioluminescent lighting could mest many Alaskan needs including remote Alaskan airfield lighting and marking.

Primary restrictions to the further development and use of the lights are the licensing requirements imposed by the Nuclear Regulatory Comisiston or foreign governments; obtaining Federal Aviation Adntinistration watvers and acceptance; tritiun availability; technical restrictions imposed by the physical limitations of the phosphor, beta-particle penetration, quality assurance and quality control: and manufacturing and production needs. The licensing issues and other federal requitenents are discussed latar and will not be further reviewed here. Because of the above mentioned 1 int tations of phosphor, tritium loading requirements, and beta particle penetration distance, 
the lights will produce only a finite light output for a given area of phosphor surface. Although this limit is not reached in existing designs, it is toubtfut that the intensity per unit area can be increased more than a factor of two over present technology. (a) Future tevelopments should thus relate to better configurations were loss of light tue to interference is reduced, or use of mirrors or reflecting materials to direct the light for more efficient use. In addition, human factors research is needed to establish how the light output is perceived by the user, that is the pilots. Minimal work has been done in this area and it has largely been 1 imited to visibllity of self-lumi nous EXIT signs. $(23,24)$ Another area that needs to be carefully addressed is the quality control and quality assurance requirements which should be imposed by aser when purchasing these lights from a manufacturer, on several occasions, lights have falled prematurely because leakage has occurred, phosphor qualty was poor, or the phosphor was contaminated. (b) In general, this has occurred when the quality control, or quality assurance criteria, have been relaxed by a purchaser. Specific needs in this area are tests to ensure tritium has not leaked out of the tubes, the phosphor is not contaminated, and that quality is maintained. A preliminary evaluation of the lights for airfield and runway use was conducted in early 1983 for military purposes and for civilian use in Alaska. Results are encouraging. At the present time, most of the restarch and development is being conducted by the government, that is DOE and Doo, but at least one manufacturer $(c)$ is atso developing light sources and designing their own manufacturing facilities. Nearly all of the manufacturers are small, having sales totalling less than 10 to 15 million dollars per year; the narket incentives need to be significant to justify relatively large financial commitment for research by industry.

(a) Telephone discussions with 0 . John Watts, Safety Light Corp, $4 / 7 / 83$ and 6/30/83; Nei1 Case and J. A. Tompkins, ORNL, 6/21/83, 8/17/83 and 9/7/83; and Larry Keating, NRD Corporation, $1 / 27 / 84$.

(b) Telephone discussions with Carl Haff and Andy Tompkins, ORNL, several occasions; W. C. Remini, DOE-HQ, several occasions.

(c) Telephone discussions with 0 . John Watts, Jafety Light Corp., 4/7/83 and $6 / 30 / 83$, and Nell Case and J. A. Tompkins, QRNL, 6/21/83, 8/17/83 and $9 / 13$. 
In summary:

1. All of the technology required is avallable to produce adioI uminescent light potentially suitable for runway lighting and for marking remote Alaskan runway.

2. Many advances in design of fixtures, which will entance the way in which the light is presented to and received by the pilot are possible. The range of these destgns is just now being explored; thus, many improvements can be expected as innovations in these destgns appear.

3. It is doubtful that the unit light intensity, that is light output from a unit surface area, can be increased beyond a factor of two. Use of mirrors, and other reflective systems, and more efficient designs that elininate interferences will enhance the human acquistition of the light. Thus, a pilot could acquire the light from a distance of 6 or more wiles rather than 2 miles acquistion identified during the $1982-83$ test in Alaska.

4. Designs of large-scale systems that use these lights are still in early development for runway lighting and marking; thus, as we better understand the human factors affecting the lights and their use under varying weather conditions, substantial improvenents in this area can be expected.

5. The lights should be sirple to instli and use, require minimal maintenance, and because they can produce 11 ght without external power at low tamperatures, should be vable for Arctic and sub-Arctic use.

6. Manufacturers could produce a radiolumi nescent light suitable for use in Alaska. They may not be capable of completing the development and demonstrations needed in 2 and 3 above to advance the technology to waturity because of internal financial linitations whout additional hel from the user, e.g., state or federal support. 
7. A better definition of the quality control and quality assurance needs for purchase of the lights is needed. Tests or evaluations needed to ensure that faflure after purchase is minimized need to be better defined.

\subsection{ENVTROMMENTAL EVALUATIONS}

Discussion in this section centers on the release of tritium and its effect an the environment. Within the discussion, various terms used in the analysis are defined along with important chemical and physicai characteristics of the trititum isotope. Finally, two possible worst-case accidents are analyzed and discussed: (1) a worker exposed while handling a fixture and (2) a large number of threshold and edge lights destroyed during an accident.

\subsubsection{Physical Characteristics of Tritium and Definitions of Terns}

The radicactive agent in RL lights, as has been discussed, is tritium. Tritium is a comonly used name for $3_{H}$, a radioactive form (isotope) of the element hydrogen. The important radiological characteristics of tritiun include its half-life, the type of radiation enitted, and the energy of the enithed radiation.

The half-life of a radioactive agent is the time required for one-hal f of the radioactive material present to undergo radioactive decay. During the second half-life period, one-hal of the remainder will decay, and so on. Each radioactive nuclide has its own characteristic half-life. The half-life of trot tum is 12.3 years. $(16,17,25)$

The type of radiation emitted will influence the shiel ding requirements for the device. Tritium enits a beta particle. A beta particle is a high speed electron, which has been enitted from the nucleus of an atom. The beta particle will eventually lose most of its energy of motion and become just another electron. Beta particles (electrons) are relatively easy to shield against. Comonly employed shielding materials include plastics, glass, and aluminum: the thickness of shielding material required depends upon the energy of the beta particle. 
The energy of a beta particle, such as those emitted by tritium, is in the form of kinetic energy, energy of motion. The energy unit used nost comonly to describe radiation energy is the million electron valt (MeV). The energy level will influence the abillty of the radiation to penetrate through matter; the grater the enero, the further the radiation will travel. A particular beta particle emitted by tritium can have a wide range of energies; however, the maximum energy that any particular beta particle will have is $0.018 \mathrm{May} .(16,17,25)$ A beta particle, such as that from tritum, having an energy of $0.018 \mathrm{MeV}$ will penetrate no more than $3 / 10,000$ of an inch through water ${ }^{(26)}$ and about $1 / 2$ inch through air. 27$)$ The glass and plastic used to contain the tritiun gas in these markers have beta shielding capabilities similar to water. The walls of the glass and plastic cylinders surrounding the tritiun have thicknesses wich vary between $1 / 32$ and $1 / 16$ inch; much greater than the distance a beta particle emitted by tritium can penetrate. The consequence of this is that any radiation enitued by tritium has insufficient energy to penetrate the walls of any confinement system, which may conceivably be used in an arfield lighting unit.

Ionizing radiation, such as the beta particle enitted by tritum, can interact with tissues of the body by depositing energy in the cells of the body and nay dismat the norma? functioning of the cell. Radiation dose is a measure of the extent to wich radiation energy has been deposited in a tissue. The wost comonly used unit of radiation dose is the rem, a subunit of a rom is a nillirem, a inllirem is one one-thousandth of a rem,

Radlation dosimetry refers to the measurement and calculation of radiation dose. Calculations of radiation doses are often used to predict the radiation dose to radiation workers in the nuclear industry or the generai population, which may occur under various circumstances. Radiation dosimetry is divided into two distinct categorfes: external dosinetry and internal dastmetry.

External dosimetry refers to the calculation of a radiation dose from sources of radiation, wich are outside of the body. There are three organs or groups of organs, for which an external dose is calculated: skin, lens of the eye, and the whole body. For purpose of calculation these organs are 
assumed to lie at a depth of $0.07 \mathrm{~mm}, 3.0 \mathrm{~mm}$, and $10.0 \mathrm{~mm}$, respectively, beneath the surface of the skin. Separate acceptable dose limits have been established for these three organ systems which are $30 \mathrm{ren}, 5 \mathrm{rem}$, and 5 rem per year, respectively. These dose limits are for individuals who work with radiation as part of their job. The acceptable annual dose limis for menber: of the general population are about 1/10 those gुiven above.

The depths given above represent the location of the radiation sensitive tissues; radiation which does not penetrate to the depth specified is considered to not provide a meaningful dose. For example, the skin consists of two major layers: the dermis and the epidernis, $(27-29)$ the dermis being the outermost layer. The epidermis is likewise composed of three layers. The cells of the lowest layer (stratum basal) are the source of new sk in in that they are continually dividing and supply new cells to make up for the continual loss of surface layers from abrasion. The lowest (basal) layer lies at a depth between 0.07 and $0.12 \mathrm{~mm}$ below the outer surface of the skin. The dose to the skin is significant only if the basal layer is irradiated because the basal layer is the source of new skin cents.

Beta particles from tritium generally penetrate only a short distance, about $0.0064 \mathrm{~mm}$, in tissue but do not penetrate to the basal layer in skin. For this reason, the radiation dose to the skin from elenental tritiun outside of the body is essentially zero irfespective of the anount of tritiun present. For the same reason, the radiation dose to the lens of the eye and the whole body from elemental tritiun outside body is essentially zero.

Internal dosimetry refers to the calculation of a radiation dose to the organs of the body from radioactive material contained within the body. The internal radiation dose is a function of the energy of the emitced radiation, the amount of radioactive material in an organ, and the mass of the organ.

Internal doses can be calculated on an organ-by-organ basis and then the organ doses $c$ an be summed to give a "whole body" dose. The calculations as sume that the radoactivity is uniformly distribited thraghout an organ, aithough the various organs may have afferent concentrations. 
The tome that the radponclide will remath in the body is a fuction of its solubility in body fluids, and whether it is incorporated into tissues, for example, bone. Collectively, the distribution of the material within the body and its eventual excretion is referred to as the metabolism of the radionuclide.

All of the energy of a beta particle whl contribute to the conputed radiation dose because the radionuclide is surrounded by fiving cells, that is in contrast to external dostmetry in which the beta particle must traverse normliving skin before irradiating living tissue. Therefore, the radiation hazaro from tritium is that which results from the internalization of tritium. The internalization may result from inhalation of air contaninated wh thetum containing materials, ingestion of contaminated materials, or absorption of tritiated water through the intact skin. The radiation dose to an individual consequent to inhalation of tritiun is dependent wpon the chemical form of the tritiums the najor chemical forms are elemental hydrogen and tritiated water.

The International comittee on Radiation protection (ICRP) ${ }^{(31)}$ estimates that the radation dose fran elenental tritiun is primarily that to the lung from inhaled tritium gas and hat the dose to the lung will be 60 to 150 tines that in any other tissue. Thus the dose calculation nethods described by the ICRP for elemental tritiurn, estimate radiation doses to the lung oniy. The biological model for tritiated water assumes that ingested or inhaled tritiated water is completely and instantaneously absorbed from the 61 tract and the lungs respectively. Further, the rate of intake through intact skin is fully one-half the rate due to inhalation. (32) The ICRP computed that $6.3 \times 10^{-\hat{2}}$ minhem per nicrocurte of tritiated water ingested or inhaled would be the radiation dose following an intake of tritiated water.

\section{3 .2 Estimation of Radiation Doses}

Owing to the radioactive nature of the tritium activated runwa markars, it is important to estimate the radiation doses, which ray be received by individuls who work with the devices, and by the general population from the tritium in the markers as a result of both normal and accident conditions. 
Under normal conditions, the tritium gas in a $\mathrm{QL}$ light is contained with in a seated glass ampule, which is itself placed within two plastic tubes the ends of which have been stoppered and sealed with a potting compound. The external radiation dose from tritiun in this configuration is zero. As discussed in the previous section, the radiation entted by tritium does not have suffictent energy to penetrate through the glass or plastic enclosures.

The internal dose potential from the use of tritiated runwayarkers is also expected to be negligible. Experiments with tritium activated aircraft EXIT lights, containing nominal activity of $4 \mathrm{Ci}^{\text {(a) }}$ were found to leak tritum gas at an average wate of about $74 \times 10^{-12} \mathrm{Ci}$ per hour through Intact glass tubes; $(15)$ an equivalent leakage rate from an indivioual light source in rumay marker is about $5.9 \times 10^{-10}$ Ci per hour. The ANS: H-540 Standard for Radioluminescent light Sources states that commercially produced light sources shall not have leakage rates greater than $50 \times 10^{-9}$ of per 24-hour period. Such a low leakage rate is insignificant for either out-of -udoors or inside well-ventilated buitdings.

\subsubsection{Evaluation of Possible Accidents}

Whing to the large number of concelvable accident scendrios, whin could be considered, it is not practical to estinate the potential for axposure or the radiation-dose potential for each. For this report, two accidents are modeled, which may be considered worst case situdtions. The first assimes that a light fixture is shattered during handing by a worker, immediately releasing its entire contents. The second assumes that the threstiold lights plus elght edge markers are destroyed at a runway accident, immediately releasing their contents.

Radiation coses fron alrborne naterials, such as tritium are dependent upon the concentrations of the radioactive material. The equations, which are used to estinate air concentrations, are not valid for distances less than

(a) Actuty is determined quantitatively by how my atams are disintegrating or enllting particles (for tritiun beta particles) per second. Thus, if the activity is $3.7 \times 1010$ disintegrations per second, the amount of raduative naterial is larie (I Ci). 
about 100 meters from the point of release. For this reason, it is often necessary to rely upon data developed from routine handing of accidents which are a rare consequence of laboratory procedures and the research and tevelopment process.

Perhaps the nost relevant exampies are incidents of this type, which occurred at Oak Ridge National Laboratory (a) and Pacific Northwest Laboratory during the preparation of tritum llght tubes or other work related to the dask an tests held during the winter of 1983-84. Individuals working in the area wen the tubes were broken hava been exposec to released tritium. These individuals had been standing at distances from 0.7 meters to several meters from the tubes when they were broken. In all but one case, the rooms were well ventilated, experiencing 6 to 10 air changes per hour. In one case, a glass tube was broken in a storage area and ventilation was minimal. The glass tube was encased in a Lexan ${ }^{\circledR}$ contaner, but the Lexan ${ }^{\circledR}$ container was not sealed. Urine samples were obtained from all hndividuals within 48 hours after exposure. Maximum dose recelved by any individual was 30 mili irem. by way of comparison, the maxinum acceptable radiation dose to a radiation worker 15 5 rem per year or 3 ren per calendar quarter; thus, in the incident described above, only a small fraction of the allowable dose was incurred. To further put these dose leveis into perspective, consider the following: flying in a commercial aircraft from Alaska to the "Lower $48^{\text {* }}$ at altitudes above $3 \hat{3}$ tot 00 th exposes the passenger to radiation from solar and cosmic sources, which are not present at the earth's surface. 5uch ratiation is prinarily gama or xuray and can contribute to radiation dose rates of 3.0 millirem per trip, and this exposure increases with increasing altitude and latitude. It is interesting to note that 10 trips are required to produce the same naximun exposure as the tritium tube breakage.

Laboratory experiments have been conducted using swine as the exposed an mal $(33)$ where larger dose rates have been buserved. An analys is of a scenario using these data was performed and is sumbarized in Appendix C. However, the long durations of exposure and other variables do not permit

(a) Leter from Karl W. Haff, OKNL, to G. A. Jensen, PNL, dated Aprj1 24, 1984. (B) Tradename of General EJectric Company Plastics Division. 
direct comparison to the above incidents, it is, of course, possible to conceive of an infintte number of accident scenarlos which could then be analyzed for risk. At this point, it is not clear what type of scenarios the licensing process wll be required to consider; however, the above examples suggest that the probable risk to humans for an RL airfield lighting systen is generally minimal.

The second accident situation considered involves the destruction of 22 markers at the end of runway as may occur consequert to an aircraft crasti. The air concentrations of tritium wera estimated at distances of 300 feet, $1 / 2,1$, and $1-1 / 2$ miles from the end of the runway. The air concentrations were estimated us ing the methods described in Requlatory Guide 1.145, "Atmospheric Dispersion Models for Potential Accident Consequence Assessments of Nuclear Power plants." (34) The assumptions used in the calculations were that 9,096 Ci of tritium were released and ind was blowing directly from the accident site to the point of calculation with a velocity of 4.5 miles per hour. Ealculations were made for points along the centerline of the runway, as well as $30^{\circ}, 45^{\circ}, 60^{\circ}$, and $90^{\circ}$ from the centerline of the runway. The results of the calculations are shown on Figures 2.2 to 2.6 , and Table 2.3. The figures show the integral air concentrations. Table 2.3 shows the radiation dose commitment. All of the doses are less than the naximum values giver in 10 CFR 32.24 for a low probability fallure condition and, except for the distances less than 300 feet from the and of a runway, all are below the maximum values given in 10 CFR 32.24 for normal use and operation.

These calculations do not estimate the air concentrations and resultant radiation ase comitment to individuals at the point of the acoident, such as to a plot of an aircratt involved in the assumed crash. As mentioned previous $1 y$, the calculational methods are not valid at very close oistances. It $c$ an be assumed that the dose comitment to a plot involved in such a crash, and to bystanders in the plume, will he larger than that to indiviauls down wind from the accident. 


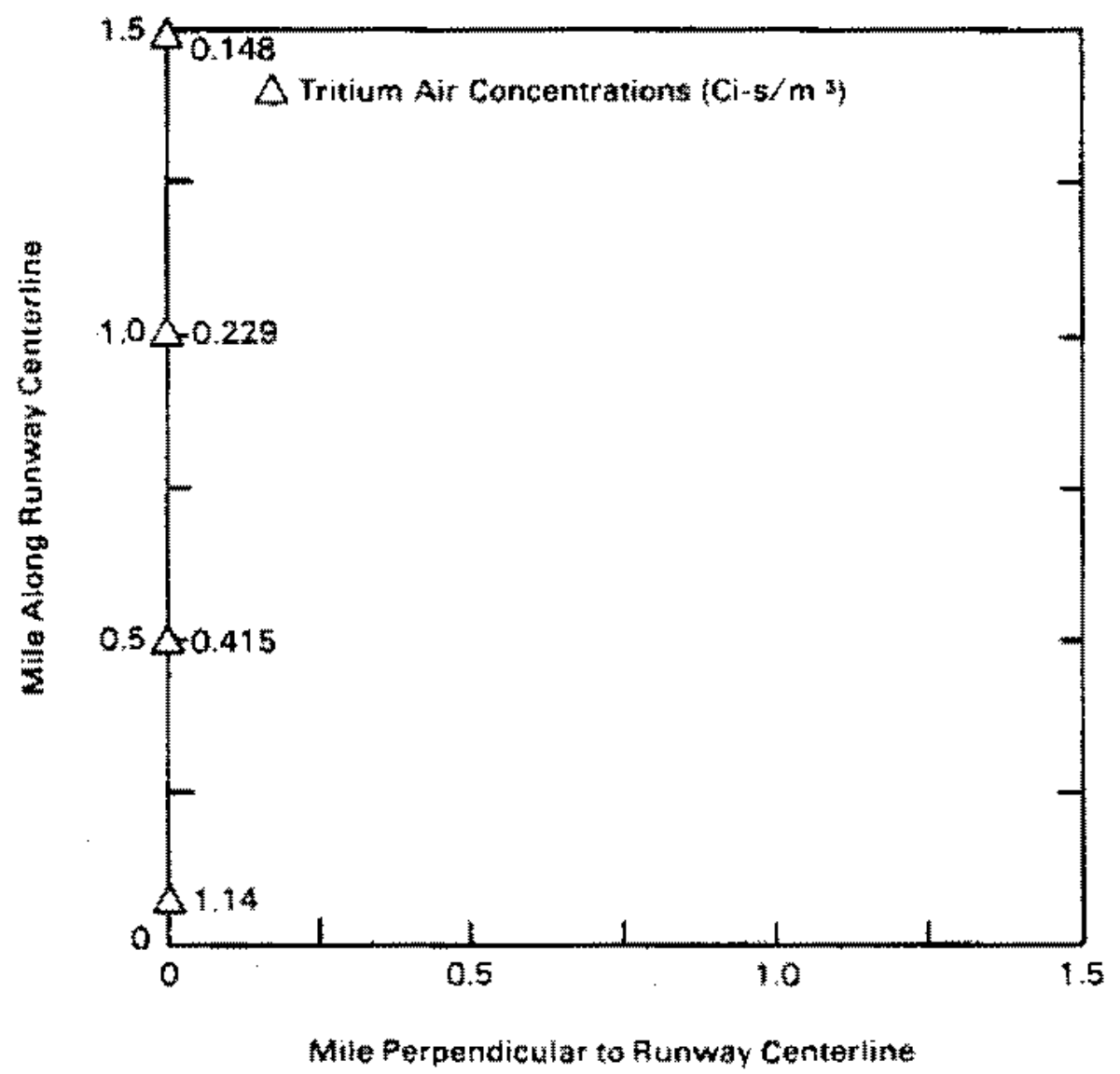

FIGURE 2.2. Integral Air Concentrations on Centerline of Runway 


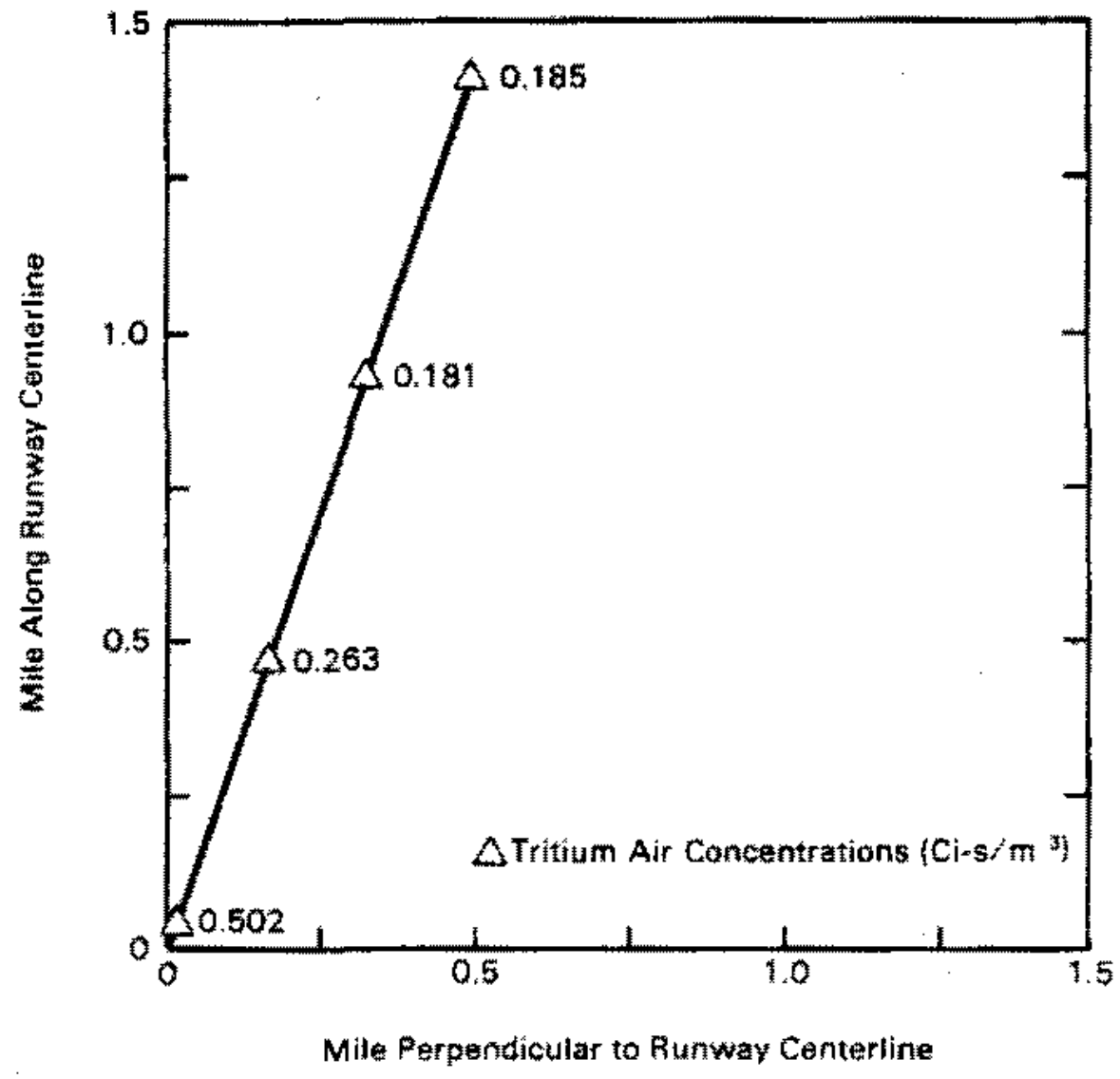

FIGURE 2.3* Integral Air Concentrations $20^{\circ}$ off Centerline of Runway 


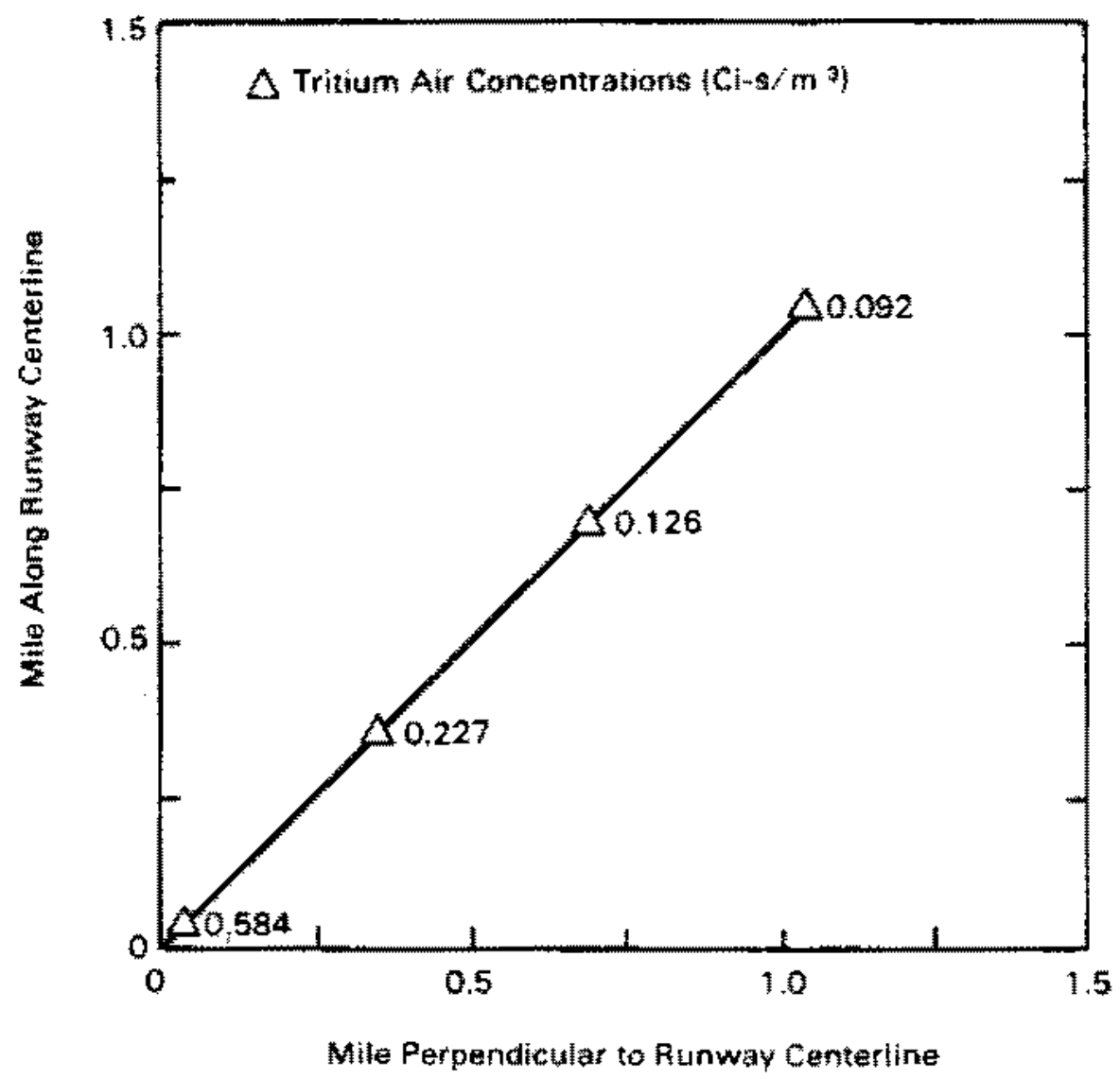

F16uRE 2.4. Integral Air Concentrations $45^{\circ}$ Off Centerline of Runway 


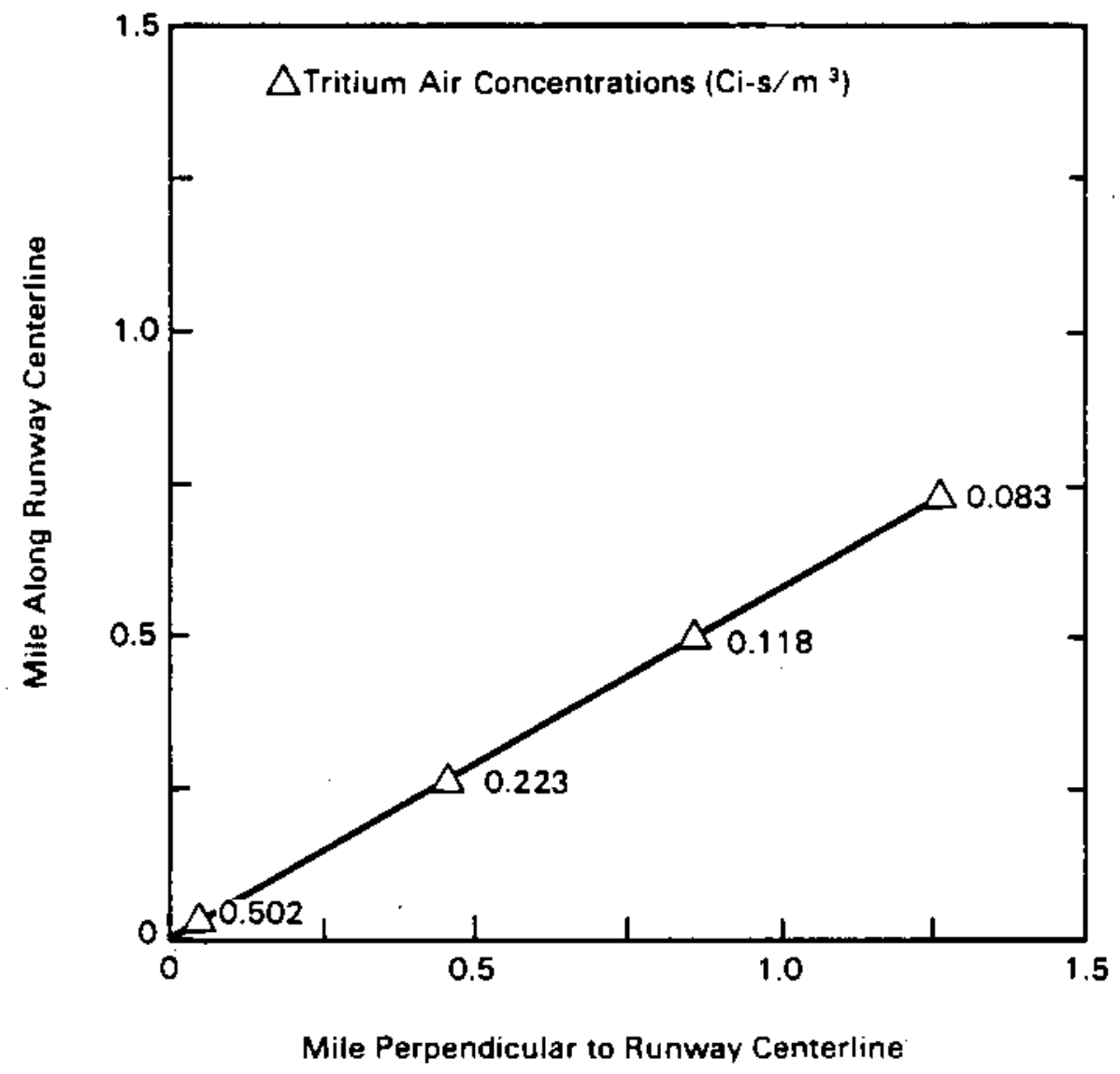

FIGURE 2.5. Integral Air Concentrations $60^{\circ}$ off Center ine of Runway 


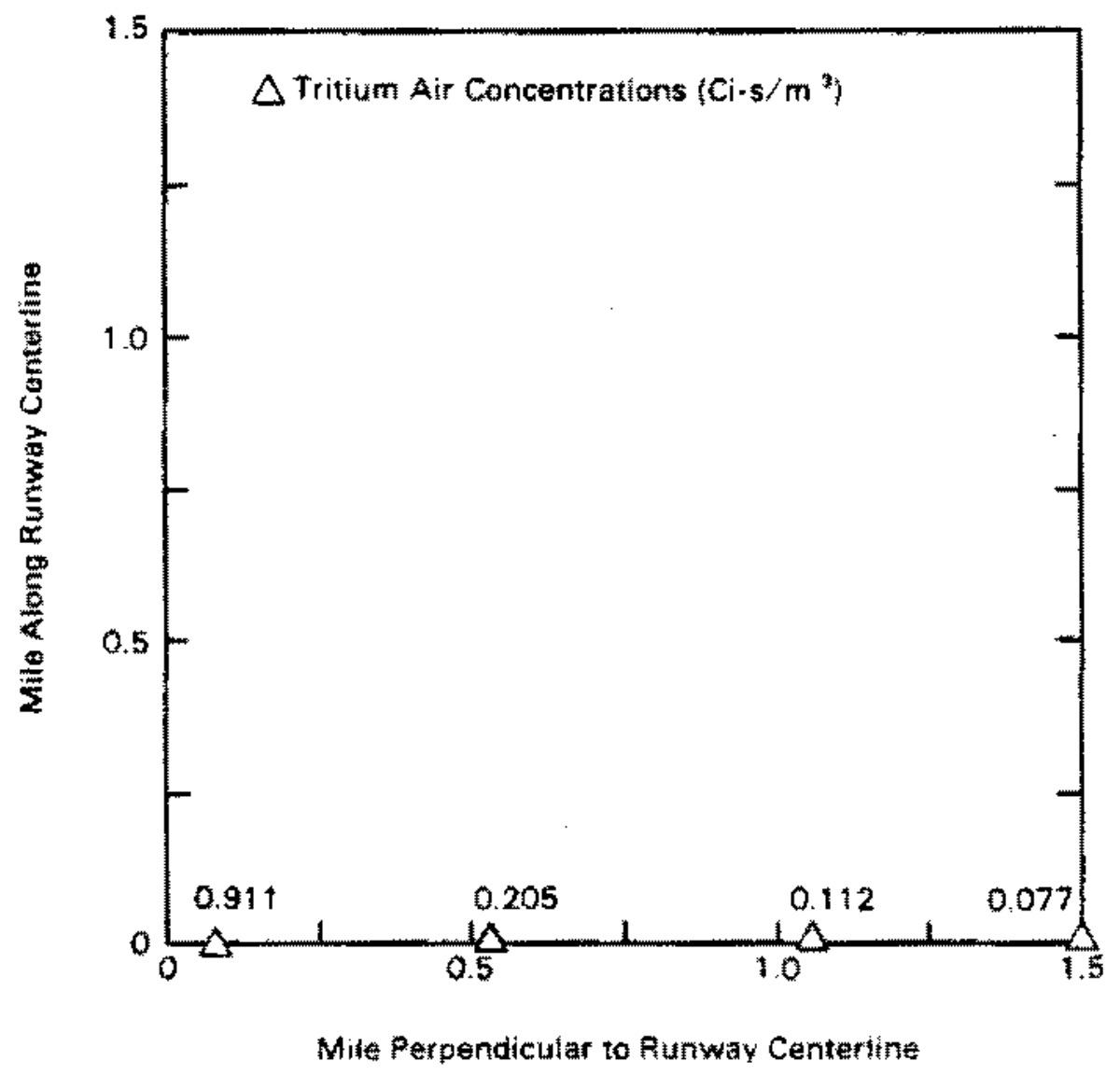

EIGURE 2.6. Integral Air Concentrations $90^{\circ}$ off Centerline of Runway 
In summary, the radiation dose from tritium activated runway markers under normal conditions is negligible. The radiation dose commitment to individuals consequent to an accident is due to inhalation of the tritium. Accidental breakage of tubes either in the laboratory or in containers holding glass tubes has produced no significant exposure. Experiments should be performed to measure the actual rate of dispersal of, and exposure to tritium following accidental destruction of a typical fixture.

The major accident involving 22 markers at one end of the runway is anticipated to be a low probability accident. The dose commitments consequent to such an accident are within the range of the maximum allowable dose commitments to members of the population under normal use conditions and are less than the maximum dose comitment for a low probability accident beyond 300 feet from the accident. For the quantities of radioactive material released when 22 markers are destroyed, the radiation dose commitments to persons in close proximity to the accident (within $300 \mathrm{ft}$ ) are expected to be large $(5.0$ rem). However, the exact doses are not known at this time.

The design criteria for items containing generally licensed quantities of radioactive material, as stated in 10 CFR 32.5 (a)(2)(iii), is that the radiation doses resulting from an accident should not exceed the doses listed in column IV of the table contained in 10 CFR 32.24. These doses are 15 rem to the whole body, 200 rem to the extremities and localized areas of the skin, and 50 rem to other organs. An enclosed area accident involving releases to give a dose of these magnitudes requires that the Nuclear Regulatory Commission be notified immediately.

\subsection{LICENSING REQUIREMENTS}

The Nuclear Regulatory Commission (NRC) is the principal federal agency responsible for licensing uses of nuclear energy. Included in this reponsibility are matters dealing with design, manufacture, distribution and use of most devices containing radioactive materials. Primary legislation for this reponsibility is found in the Atomic Energy Act of 1954. This act assigned primary responsibilities for the promotion and development of peaceful uses of atomic energy to the Atomic Energy Commission (AEC). 
TABLE 2.3. Computer Dose comitments Due to Intalation of Tritium Following a Major Accident (Dose in ren)

Angle from Centerline of Runway

On centerline

$20^{*}$ off centerline

$45^{\circ}$ off centerline

$60^{\circ}$ off centerline

$90^{\circ}$ off centeritine

\begin{tabular}{|c|c|c|c|}
\hline \multicolumn{4}{|c|}{ Distance } \\
\hline $300 \mathrm{Ft}$ & 172 mite & I Mile & I-1/2 MiTe \\
\hline $2.4 \times 10^{-2}$ & $8.7 \times 10^{-3}$ & $4,8 \times 10^{-3}$ & $3.1 \times 10^{-3}$ \\
\hline $1.1 \times 10^{-2}$ & $5.5 \times 10^{-3}$ & $3.8 \times 10^{-3}$ & $2.8 \times 10^{-3}$ \\
\hline $1.2 \times 10^{-2}$ & $4.8 \times 10^{-3}$ & $2.3 \times 10^{-3}$ & $1.3 \times 10^{-3}$ \\
\hline $1.1 \times 10^{-2}$ & $4.7 \times 10^{-3}$ & $2.5 \times 10^{-3}$ & $1.7 \times 10^{-3}$ \\
\hline $1.9 \times 10^{-2}$ & $4.3 \times 10^{-3}$ & $2.3 \times 10^{-3}$ & $1.6 \times 10^{-3}$ \\
\hline
\end{tabular}

Legislation since this original act, notably the Energy Reorganization Act of 1974 , separated the pronotional functions from the regulatory functions and created the NRC. By this act, the NRC was delegated authority for handing licensing and regulation of all facllities and materials licensed under the Atomic Energy Act of 1954, as ammended, including such matters as safeguards, transportation, byproduct and special nuclear materials and confirmatory research.

other federal legislative actions wich affect the use of radioluminescent lights in Alaska inciude the National Environmental Policy Act of 1969 (NEPA) and Executive Order 11514 which sets forth a policy to encourage hamony between man and his environment and the Federal Water Pollution control Act (FWPCA). The AEC in January 1973 (38 CFR 2679 January 29, 1973) developed a policy statement regarding the effect of ammencments to FWPCA and the AEC's responsibilities in implementing NEPA and FWPCA. This interim pol 1cy statement and a memorandum of understanding is still in effect under NRC. It is the provisions of these acts which have allowed DoE and its National Laboratories to bring the lights to Alaska for testing in the winters of $1982-83$ and for planned testing in 1983-04. Further licensing of these 1 ights by the State of Alask for use in Alaska for lighting and marking w111 be handled under the provisions of this legislation and the rules of Title 10, Code of Federal Regulations, Parts 30 through 35 (10 CFR $30-35)$. (35) Most of these regulations are directed at use of millicurie quantities of radiolsotopes rather than the larger multicurie quantitues of tritium, krypton-95, etc., to be used in radioluminescent lights for runwa lighting and marking purposes. 
The NRC issues either a general or a specific license for use of byproduct $^{\text {(a) }}$ materials. A specific license is issued to a named person upon application filed pursuant to the regulations in 10 CFR 30-35. General licenses are effective without the filing of applications with the NRC or the issuance of licensing documents to particular persons. Under Section 31.5, the NRC issues a general license permitting anyone to receive, possess, use, or transfer byproduct material contajned in, among other things, "devices designed and manufactured for . . . producing light," provided the devices have been manufactured and initialiy transferred in accordance with a specific iicense issued pursuant to Section 32.51 , or the equivalent requirements of an Agreement State. (b) For example, commercial aircraft such as Boeing $727^{\prime}$ s carry about 200 curies of tritium in several EXIT signs and hospitals and buildings using these devices may have up to a total of 1500 curies in various safety lighting items. AT1 of these devices have been manufactured and transferred in accordance with the provisions of 10 CFR 32.51. Alaska is not an agreement state at present and so Alaska DOT\&PF would be subject to the provisions of these regulations and guidelines $(35,36,37)$ when using radioluminescent lights. Section 32.51 defines the requirements for NRC issuance of a specific license to manufacture or initially transfer devices containing byproduct materials for use under Section 31.5. The state could insist that each light used be manufactured in a fashion that it could be a licensed $i$ tem and that the needed quality control and assurance testing are completed. Since each light is expected to contain more than 30 curies of

(a) Title 10 Code of Federal Regulations, Part 150.4 (10 CFR 150.4), "Byproduct material" means: (1) any radioactive material (except special nuclear material) yielded in or made radioactive by exposure to the radiation incident to the process of producing or utilizing special nuclear material; or (2) the tailings or wastes produced by the extraction or concentration of uranium, thorium or thorium from any ore primarily for its source material concent, including discrete surface wastes resulting from solution extraction processes. Underground ore bodies depleted by such solution extraction operations do not constitute "byproduct material" within the definition Ref. 10 CFR 150.4.

(b) Title 10 Code of Federal Regulations, Part 150.4 (10 CFR 150.4), defines an agreement state as follows: an agreement state means any State which the Commission or the Atomic Energy Commission has entered into an effective agreement under subsection 274b of the Act. (Atomic Energy Act of 1954) "Nonagreenent State" means any other State. 
tritium, the major burden for licensing would be placed on manufacturers, who would be required as a minimum to complete and neet the testing and certificam tion requirements juentified in $\mathrm{U} . \$$. Department of Comercul National Bureau of Standards, American National Standard N-540, (37) Specific documentation to meet 32.51 (a)(2)(ii and ili) and 32.51 (b) would be provided by the manufacm turer. 0ther requirements would be met by dientifying specific individuals or organtzations who hat the approprlate qualifications.

In the case of the radioluminescent lights and their use, the required documentation for the state having a license should be minimal. Specific reasons for this are identified in the section on environnental evaluations. The manufacturer's general license for the light itself should suffice providing the state has appropriate storage and handling factlities for use in installation and replactment purposes. At the present time, it is difficult to establish the specific requirements because no precedent exists for use of as large a quantity of tritium (50 to 100,000 curies) as would be required to light a runway. Additional tests nay be required by NRC for issuance of a general llcense. Here again, the manufacturer would have the major responsibility.

Among the specific requirements, which could be imposed under 10 CFR that wuld pertain to the State of Alaska's use of these devices are the following:

$30.33(a)(2)$

(by reference)

$$
\text { - } 30.33(\text { a) } 3 \text { ) }
$$

by reference)

- 32.5(ta)

(by reference)
The applicant's proposed equipnent and facilities are adequate to protect health and mintiolize danger to life or property.

The appilicant is qualif led by training and experience to use the naterial for the purpose requested in such a maner as to protect health and minimze danger to life or property.

The applicant submits sufficient information relating to ine design, manufacture, prototype testing, quality controls, labels, proposed uses, installation, servicing, leak testing, operating and safety instructions, and potential 
hazards of the device to provide reasonable assurance that:

(i) The device can be safely operated by persons not having training in radiological protection.

(ii) Under ordinary conditions of handling, storage, and use of the device, the byproduct material contained in the device will not be released or inadvertently removed from the device, and it is untikely that any person will receive in any calendar quarter a dose exceeding 10 percent of the limits specified in Section 20.101 (i.e., 10 percent of $1.25 \mathrm{rem} /$ quarter for whole body; head and trunk; active blood forming organs; lens of eyes; or gonads: $18.75 \mathrm{rem} /$ quarter for extremities, $7.5 \mathrm{rem} /$ quarter for skin).

(iil) Under accident conditions (such as fire and explosion) associated with handing, storage, and use of the device, it is unlikely that any person would receive an external radiation dose or dose commitment in excess of that specified in column iv of the table in section 32.24 (i.e., 15 rem whole body, 200 ren to the extremities and $\mathrm{skin}$, and 50 rem to other organs).

- $\quad 32.51(b)$

(by reference)
If the applicant desires that the device be required to be testad for proper operation and for leakage at intervals longer than six months. he inust submit additional information for the Comistion's consideration on: 
1. Primary containment (solirce capsule)

2. Protection of primary containment

3. Method of sealing containment

4. Containment construction materials

5. Form, quantity, and radiotoxicity of contained radoacthe materials

6. Maximum temperature and pressure withstood during prototype test

7. Operating experience with similar devices

The shipment of radioactive material between states by rail, air, road, or water is regulated by the U.S. Department of Transportation as spectfied in Title 49. "Transportation" of the Code of Federal Regulations, Parts 100-199 (49 CFR 100-199). (38) In special cases, the NRc also regulates the packaying of radioactive matertal for transport and transportation of radioactive material under certain conditions as specified in 10 CFR 71 . In addition, state laws and local ordinances will have to be complied with ouring shipping of the lights. The detai is of these requirements are so varied that they 111 not be sumarized here but no difficultes are foreseen in transporting the devices to Alaska if properly packaged and handled. Current sate laws and regulations are identlied and compled in NUREG/CR-1263(5.2). (39) Applicable regulatory guides are attached in Appendix $D$.

In summary, either a general or specific license can be applied to the use or possession of tritium activated runway markers. The license category most appropriate for these devices will be dependent upon the extent to which these markers have been tested and the results of the tests. The tasts to which these devices should be subjected are simllar to those describen in 10 CF 32.101 Schedule B - Prototype Tests for Luminous Safety Devices for Use in Aircraft, and Amertcan National Standard N-540-1975, "American National Standard $\mathrm{N}-540$; Classification of Radioactive Self-Luminous Light Sources." The t.ypes of tests required include drop tests, vibration tests, puncture tests, and shock tests. A single marker must be able to pass all tests whout breaking or leating radioactive material. These tests should be performed ty the manufacturer. $(35,36)$ 
The least burdensome license, from the standpoint of the user, for which tritium activated rumway markers would be eligible appears to be as a generally licensed quantity; the quantity of radioactive material is too great to be considered an exempt quantity. However, this general licensed quantity status has not been achieved. Thus, a specific license of broad scope may be necessary. Wwing to the fact that these devices are relatively new, the exact restriction that ma be imposed upon the licensee are unknown. Discussions with NRC staff have indicated that the restrictions will be dependent upon the tests to wich these devices have ben subjected and the resul ts of the tests. Speciftcally, if the lights have not been registered with the NRC, they may be treated as experimental devices and many restrictions may be placed upon the licensee including a requirement for a radiation safety officer, and a radiation safety comittee; also the undtendad use of these devices may not be allowed. At the same time that a license application is made to possess the sources, a request for a custom review should be made. The request for a custom review is generaliy made by the user; however, the supporting data requested by the NRC should be provided by the manufacturer. The effect of a successful custom review of these runway markers is that the license restrictions may be no greater than those restrictions placed on generally licensed quantities of byproduct naterial.

\subsection{INSTITUTIONAL ISSUES MNO EDUCATION}

Public acceptance of the radioluminescent lighting technology at the community level is critical to the overall success of the program. During the demonstration phase, it will be important to understand public concerns with RL lights and to be able to commicate effectively to the public. The main factors that inpact public acceptance include: concerns with radioactive substances; perceived costs and benefits of the technology; local economic impacts; direct prior experience with new technology and related developments; role of activist organizations; and characteristics and level of organization of candidate site communities.

Because of the radioactive properties of $\mathrm{RL}$ lights, public concern can be expected. Soctal scientists working in Alaska and individuals involved in public and privately supported environmental organizations vary in their 
estinates of the degree and character of public concern. However, there is concensus that some public response could be expected regardless of the remoteness of the commity. The view was expressed that people would readily see the benefits that would accrue to their village or borough as a result of the installation of the R. IIghts for airstrips; the benefits of the technology, when clearly understood, should assure rapld acceptance. (a) Another perspective was that sone resistance and negative response could be expected with the introduction of these lights, regardless of where they are sited. However, it is also anticipated that once issues are sorted through, the major concern of most groups (in particular, native groups) would be the effect of RL lighting on restents livel ihood. (b)

Public perception of nuclear issues, wich is relevant to the acceptance of RL lights, has been found to vary areatly. 40,411 This preliminary inestigation suggests that public acceptance of RL lights will vary by the locations of the site comunities in the state. Several factors were mentioned in recent discussions with experts in Alaska as potential aspects of geographic differences. For example, it could be expected that to the extent that various population groups have been exposed to the impacts of other development activities, like oll development, they wold hold a more catious vie of the benefits of ther efforts. Cosstal groups were seen as those population areas that could be expected to have the greatest number of formally or informally organized opposition groups that are ready to mobilize and carefully question any new development efforts. (b) others felt that smaller towns may not be able to mount a response. Also yoiced was the view that some villages mey oppose most any development simply because of the nature of the residents. One case was cited were villagers living next to oxw line becane concerned regarding the effects of the nicrowaves on the local

(a) Conversation between Chris Cluett, Human Affairs Research Centers (HARC). PNL., and Dan Rogness of Alaska Public Health Service, Environmental Heal th Branch, August 2, 1983.

(b) Conversation between Coris Cluett, HARC, PNL, and Patty McMillan, anthropologist with the Arctic Environmental Information and Data Center. Anchorage, Alaska, Augus 3, 1983. 
population. (a) The controversy apparently died dow after a government expert was sent in to evaluate the situation.

A public education and information progran should be carefully designed to be senstive to the characteristics of the area where RL Iights will likely be introduced and to the particular concerns of the local residents. Thus, the program is being designed not to force a technology on an unwilling public but rather to understand and be responsible to public concerns: that is, the program is destigned to create a level of acceptance that will help ensure the success of the program. Some of the issues of public concern that can be effectively dealt with through a program of public education and information include: hell th and safety issues; RL lights disposal problens: impacts of vandalism and preventative measures; and public particlpation in siting decisions.

Heal th and safety concerns with technology development are typically felt. by sma11 communities and should be addressed by this program. Concerns, such as whether or not radiation can enter the food chain and arrangements for eventual disposal of the lights are topics that have already been raised $(\mathrm{b})$ and are addressed elsewhere. Other questions that might arise focus on the like inood that radiation could escape fron the lights die to events, such as vandalism. This later issue is more likely to be a concern in comunities were simflar events have occurred in the past; preparatory research into the frequency of similar events in candidate communities needs to be evaluated during the demonstration planned at Central, Alaska, this year.

Public information prograns or messages are al so influenced by the way in which they are delivered: the media (e.g., TV, radio, or newspapers); the source tcommunity opinion leader, public figure, or national political figure); and even the language of such messages influence whether or not people listen to or accept this information. $(42,43)$ sensitivity to these

(a) Conversation between Chris Cluett, HARC, PNL, and Dan Rogness, Alaska Publ te Heal th Service, Environmental Heal th Branch, Augus 2, 1983.

(b) Conversation between Chris Cluett, HARC, PNL, and Mary Core, Executive Director of Issues, Alaska Center for the Environnent, August $5,1983$. 
variables and their application in the candidate comunities should be planned for in undertaking a public information program for the demonstration phase.

The objective of these public information programs should be to educate the concerned public regarding both the benefits and the costs of RL lights. In some instances, public information can be adequately distributed in print or electronic media. Because of the likelihood that use of RL light will arouse public concern, provision should be made for a forum for public participation, such as tow meeting or other public meetingl. Careful preparation is vital regarding issues that are most likely to be of greatest concern to the candidate comunt ties. Analyses of public responses to other nuclear-related technologies and concerns expressed by scientists and environnental groups indicate that health and safecy issues will be forenost. among public concerns. There is also a recognition that the residents of Alaska are concerned about their traditional way of life; developments that benefit or hinder their capability to sustain themselves in an accustoned manner will be viewed with distrust and opposition. Clearly a pubilic information program prior to the introduction of these lights should be undertaken with careful and thorough consideration of how to present the issues of greatest concern to the candidate comunities.

\subsubsection{Human Factors Needs}

The design of a radioluminescent lighting system for remote Alaskan runways and the demonstration of that system in its design environment: presents a number of human factors issues that should be addressed. The following are the major human factors issues that should be investigated in planning for and conducting the demonstration phase of this project.

\section{5 .1 .1 Pilot Acceptance and Performance}

The use of RL lighting will present the pilat wh unfamiliar visual cues that may affect spacial orientation and depth perception and perhaps other perceptual areas. These factors will, in turn, affect pilot acceptance. There have been nuber of studies by the office of Naval Research, the Air Force Aerospace Medical Diviston and the FAA in the general ared of nigit approaches and landings us lng various lighting systems. In addition, the Air 
Force is continuing its research in the area of electroluminescence and its effects on aircrew vision. The data from these sources should be revieved and evaluated as an on-going part of this project.

of particular importance will be the preflight briefings, These are needed to acquaint the flight crews of the purpose of the evaluation prior to evaluations of lights and the specific data to be collected. If possible, visual aids such as $\$$ till photography or video tapes of approaches to R!-lighted rumways need to be included. In addition, the post-flight debriefing/da acquistiton protocols are being developed. These should be sharply focused, asking such questions as: "At wat al tilude and attitude did you first detect the runway?" rather than: "When did you first see the 1ights?" The Dotspr questionnalre used in the 1983 testing at Malamute Airfield colld be used as a starting pofnt.

\section{5 .1 .2 Personnel Fraining}

The use of Ri. lighting may require special training for the people who handle, store, install, maintain, and dispose of system components. These requirements should be defined as an integral part of the effort and evaluated during the demonstration phase.

In formulating specific training requirements, a scenario should first be developed for the demonstration. The scenario should then serve as the basis for determining the tasks required of people who will handle, store, maintain and dispose of the system. This, in turn, will lead to a list of training requirments and a training plan. In addition, a plan for data collection and analysis should be developed.

\section{5 .1 .3 Operating and Maintenance procedures}

Concurrent, with the identification of trainging requirements, it is essevtial to begin development of procedures for all phases of the project. This includes the identification, handing, and disposal of damaged components that might pose a hazard to people. The task analysis mentioned above will yield information on those tasks that require written procedures and also provide a bas is for selecting procedure formats. procedures should be ready, at least in preliminary form, for the demonstration phase so that they can be evaluated for their technical accuracy, acceptance, and usability. 


\subsubsection{Human Factors Engineering Assessment of System Design}

The human factors engineering aspects of design should be considered during the design phase and evaluated during the demonstration phase. Factors to be considered are: (1) ease of handling and storage both in transit and on-site, (2) maintenance and test equipment; and (3) component containers especially those designed for shipping of damaged components containing radioactive material. 


\subsection{ENGINEERING EVALUATIONS AND DESIGN CONSIDERATIONS}

\subsection{AIRF IELO LIGHTING RESPONSIBILITY}

Radioluminescent lighting systens are mainly being developed to serve rural Alaskan airfields up to 4000 feet in length. Single- and twin-engine, light intermediate speed aircraft are the primary traffic at these airfields. The supply, installation, and matntenance of any runway lighting system is normally the responsibility of the airport owner/operator. Of specific concern are the airports owned and operated by the Alaska DOT\&PF. However, any airport lighting system is subject to Federal Aviation Administration (FAA) approval before it can be used by commercfal pilots for night operation while carrying passengers. Under current FAA regulations, the minimum airfjeld lighting systen acceptable for use at State-owned and/or operated airports would be a Medium Intensity Runway Lighting System (MIRL) as described in FAA advisory circular No. AC 150/5340-24. Since federal regulations perat no modification to lighting specifications at the Regional level of FAA (in this case the Alaska Region) at the present time, the RL system clearly cannot be considered as substitute to MIRL. However, FAA does recognize that special circumstances nay necessitate night operation of an aircraft in and out of an airfield that is not equipped with a MIRL. system. For this reason, the FAA regional authority may permit a specific air carrier to conduct night operations at an unlighted airfield if illuminated by flare pots or lanterns. This process is administratively addressed by FAA through modification to the operator's specification, which is issued to licensed air carriers under Part 135.229 FAR.

Since the RL system is not expected in the near term to be a completely acceptable al ternative to an MIRL system until operational experience is gained, it must be treated administratively as flare pot or lantern al ternative for an administratively acceptable definition. With this distinction in mind, the development of a RL system will continut toward eventual implementation into routine use in Alaska with the following authorities and points of cooperation required: 
ENTITY

United States

Department of Energy
ACTION

Must transfer technology to private sector and make enough tritium avallable to indus try.
EFFECT

Commercial and competitive interest is aroused.
Comercial manufacturer
Apply for and recelve WRC general license to manufacture and sell RL. alrport lighting system components.
Equipnent becones comercially ayailable.
Procure and install

a standardi zed RL lighting systen, which FAM has recelved acceptable, at an arport.
A runway marking system is installed.
Department of Transportation and Public Facilities
Apply to FAA for modification in their operating specification and negoti-. ate with FAA the specific details of operation ganted under the modification.
Night operation is permitted under a prearranged set of criteria.
Develop a policy to deal with inproved flare pot systems for conmercial carriers under Part 135 FAR and general aviation.
A routine procedure is es tably shed that will permit improvements in safety and air service to the consumer.

\subsection{DESEGN OEVELOPMENT}

A RL system suitable for use in Alaska at rural runwas has begun to evolve. At a demtonstration of tritium wands (see figure 3.1) used for airfield marking at Bouge Field, North Carolina, in August of 1982, 00T\&PF personnel first observed the lights. PNL personnel had observed earlier versions of the RL 1 ights but not the wand. This demonstration was sponsored by DOE and was conducted by Dak Ridge National Laboratory. From this point an iterative process of design modification and evaluation has continued and is still in progress. 


\section{INDIVIDUAL LIGHT}

TUBES INSIDE HIGH

IMPACT STRUCTURE

\section{SPIKE FOR}

IMPLANTING

IN GROUND

FIGURE 3.1. RL Wand 


\subsubsection{Bouge Field, August 1982}

At the Bouge Field test, the 4000 foot runway was configured as shown in Figure 3.2. Observations were made by simulating fixed wing aircraft approaches with an Army National Guard UH-1 hel icopter. The results of these observations by Lee Leonard, of Alaska DOT\&PF, and Lyle Perrigo, of Battelle Alaska Operations, are as follows:

At approach speeds of about 80 knots and an al titude of about 1000 feet, the lights seemed to appear all at once at about 1 to $1-1 / 2$ miles with the naked eye and at about $1-1 / 2$ to $2-1 / 2$ miles with second generation night vision equi pment.

\subsubsection{Alaska, January-February 1983}

Following the Bouge test, a test was planned for the winter of 1982-83 in Alaska. Because of the environmental conditions anticipated in Alaska, it was agreed that the simple fixture system used at Bouge would not be adequate for use in Alaska. During the autumn and early winter of 1982, DOT\&PF and PNL worked with Oak Ridge National Laboratory to develop a portable fixture element suitable for Alaska. The Alaska Air National Guard provided logistic support by and assistance to wind-test prototypes.

Figure 3.3 shows the final prototype selected for use. A break-away plastic traffic cone is truncated and fitted with a wooden plate to receive a six-inch diameter plastic cylindrical light fixture enclosing four tritium wands, each wand containing approximately 100 curies. This basic fixture was then tested in Alaska at two locations:

1. At Clear Creek strip, approximately 20 miles southeast of Fairbanks, from January 17 to February 2, 1983, as part of the "Brimfrost-83" joint military exercises.

2. Malamute Landing Zone at Ft. Richardson near Anchorage, Alaska, on February 4 to 7,1983 , as a test and demonstration conducted by the DOT\&PF and the Alaska Air National Guard with assistance from the Alaska Region FAA Flight Standards Dffice.

Field support for both the Clear Creek and Malamute tests was provided by DOT\&PF, ORNL and PNL. 


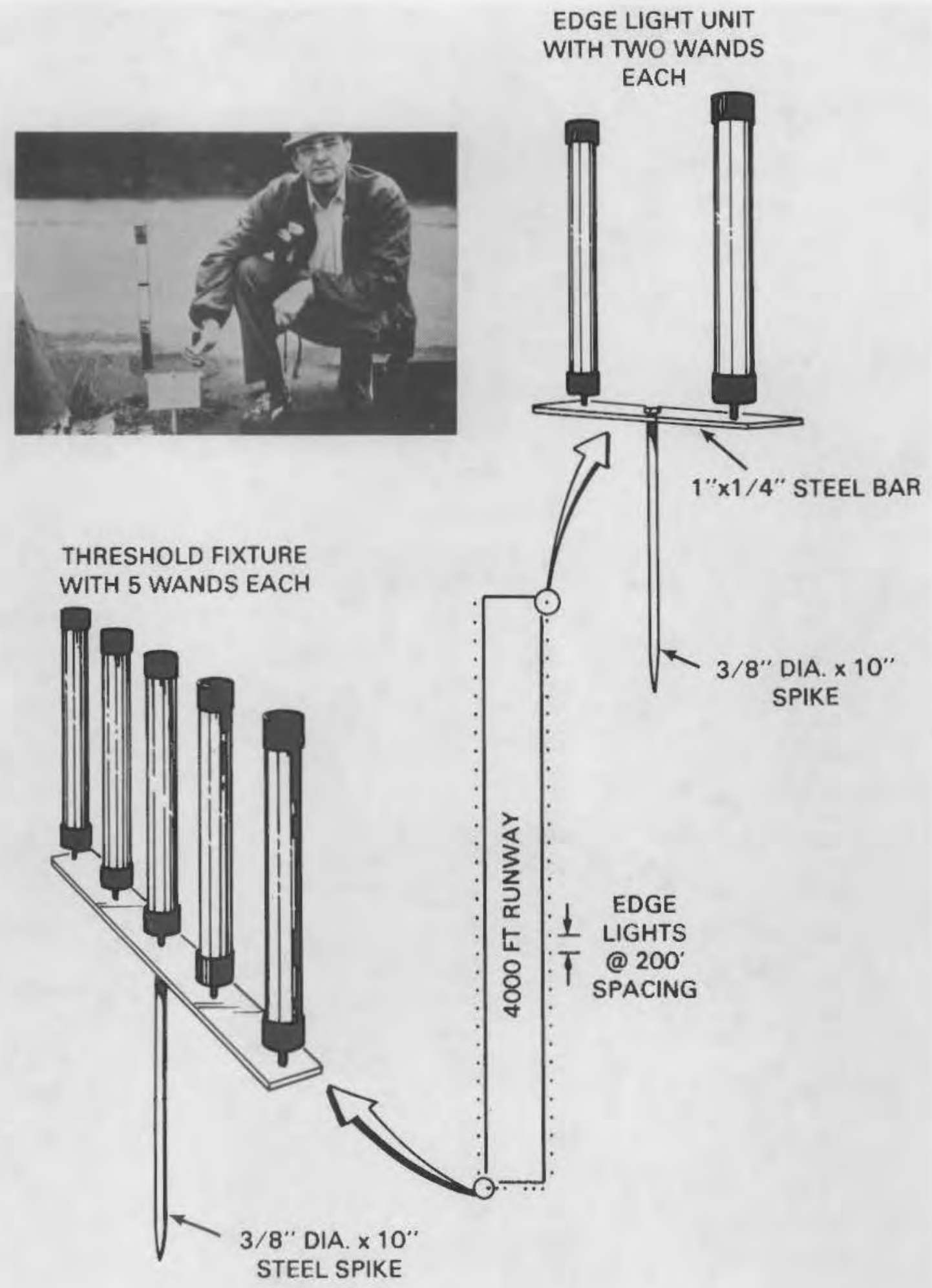

FIGURE 3.2. Bogue Field RL Lights and Fixture 


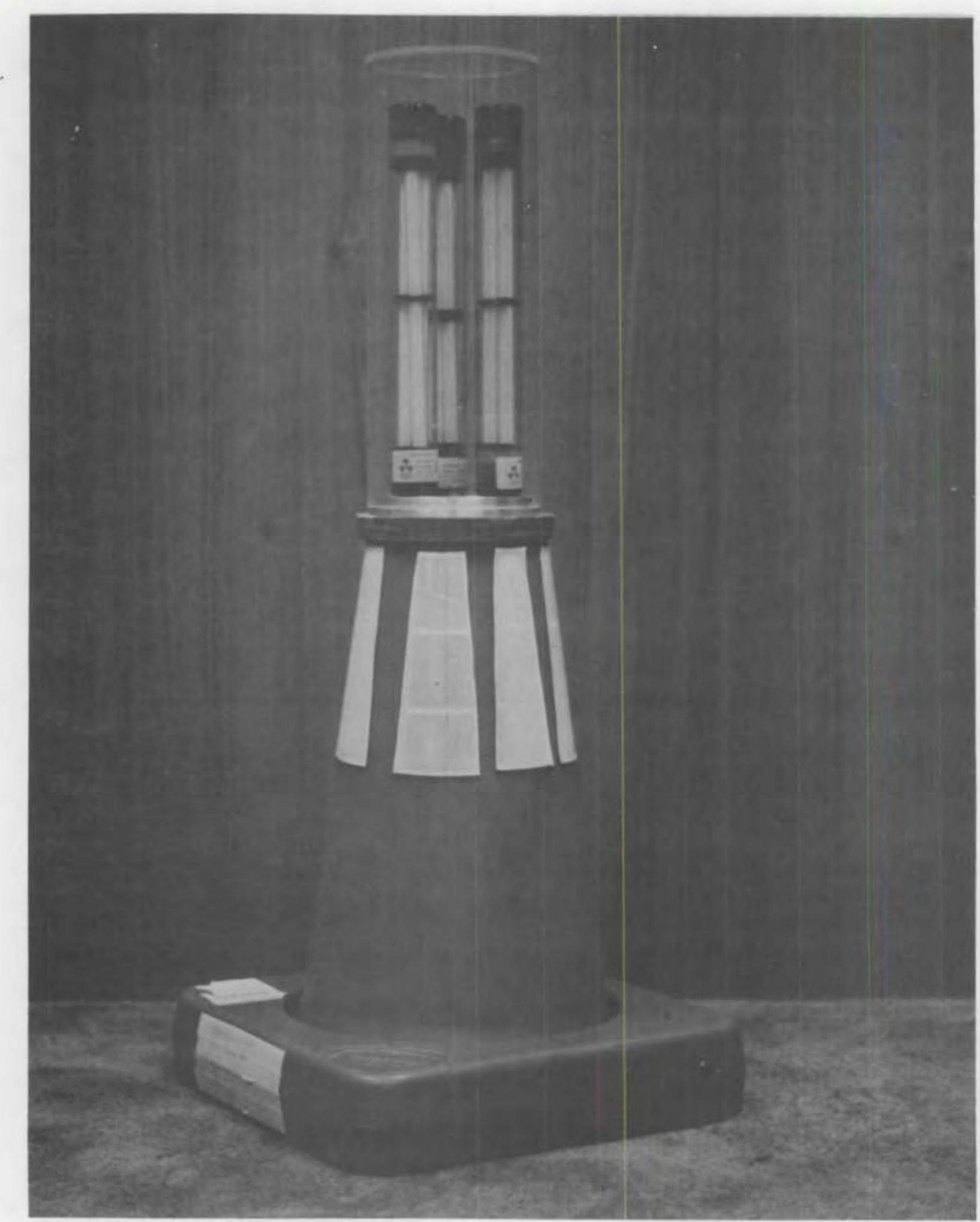

FIGURE 3.3. Prototype Light Fixture 
The Brimfrost test provided little information to the DOT\&PF as far as gathering data on light aircraft operation to the RL system because flight operations were largely 1 imited to $\mathrm{C}-130$ or UH-1 aircraft. However, the test was a good shakedown for both the U.S. Air Force and DOT\&PF. Pilot observations were gathered and considered for eventual sys tem improvements.

\subsubsection{1 "Brimfrost 83" Tests}

Configuration

For the Brimfrost exercises, the runway lighting was configured as shown in Figure 3.4. (44) Edge and threshold light fixtures were of the type shown in Figure 3.3 with three visible wands and one infrared wand per fixture. A special visual approach slope indicator (VASI) as shown in Figure 3.4 was also installed (see Figure 3.5 for the geometry). To provide for greater visual acquisition distance on approach and to aid the pilot in acquiring horizontal alignment, an extra set of panels were set up as a lead-in light array at 500 feet spacing off the south threshold al so shown in Figure 3.4.

\section{Observations}

As at Bouge Field, a helicopter was used to simulate fixed-wing approaches for the field test crew. In the case of Clear Creek, several distractions in the form of incandescent flood lights in the area of the encampment of soldiers and support facilities compounded the problem of evaluating the lights. However, several observers were able to pick up the lead-in lights and VASI system at a distance of three miles or greater with the edge lights appearing at 1 to 2 miles. While the acquisition distance for the edge lights was similar to the Bouge Field experience, the lead-in lights and VASI affected pilot perception. Evaluations at Clear Creek indicated that the parallel tube array with reflective backing as used in the VASI and lead-in el ements were superior to the wand-type of edge lights for absolute range of acquisition.

Air Force pilots flying $\mathrm{C}-130$ aircraft and landing at Clear Creek Airfield were asked to evaluate the lights as an operational system. The 


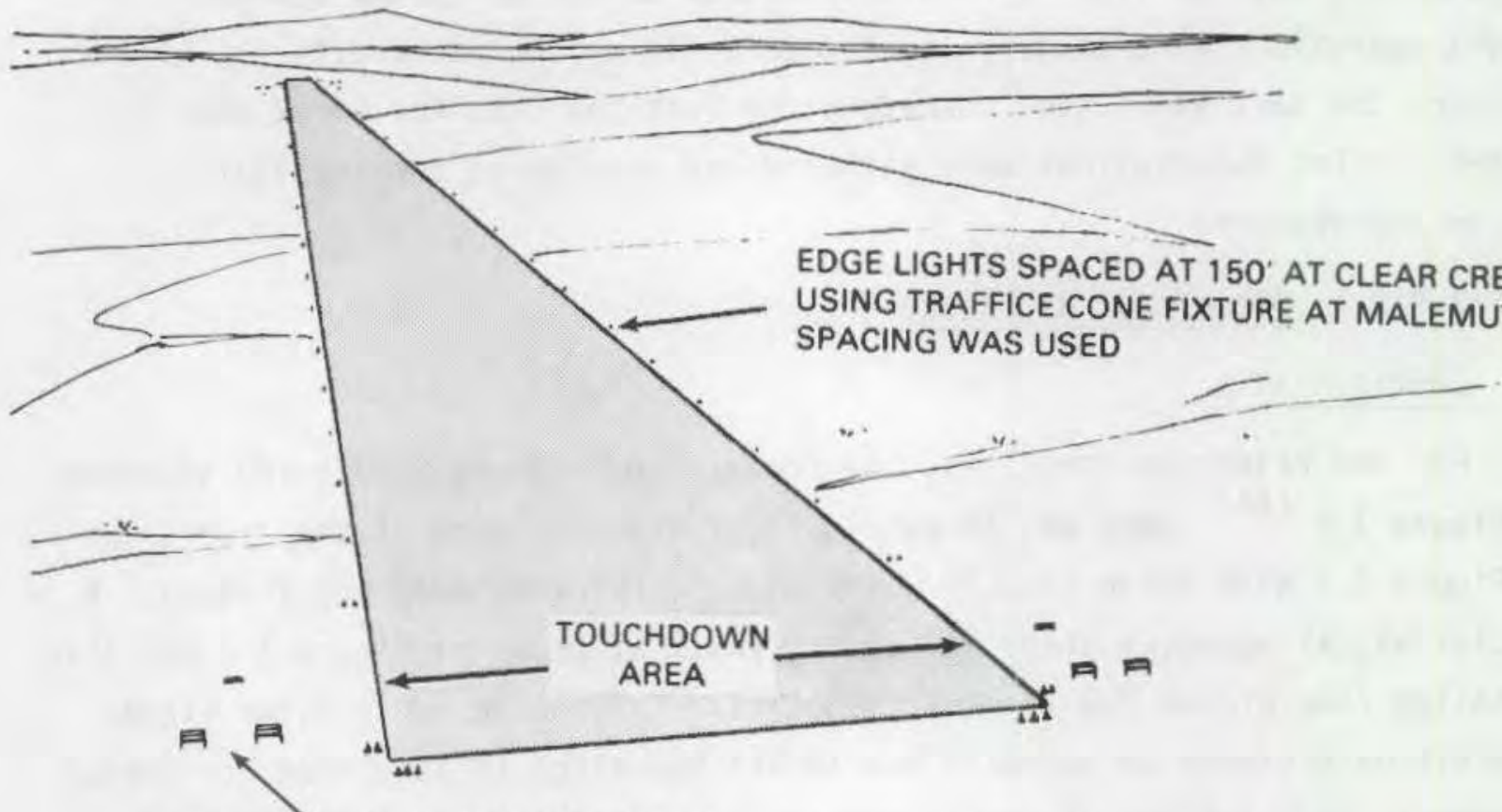

RL VISUAL APPROACH SLOPE INDICATOR

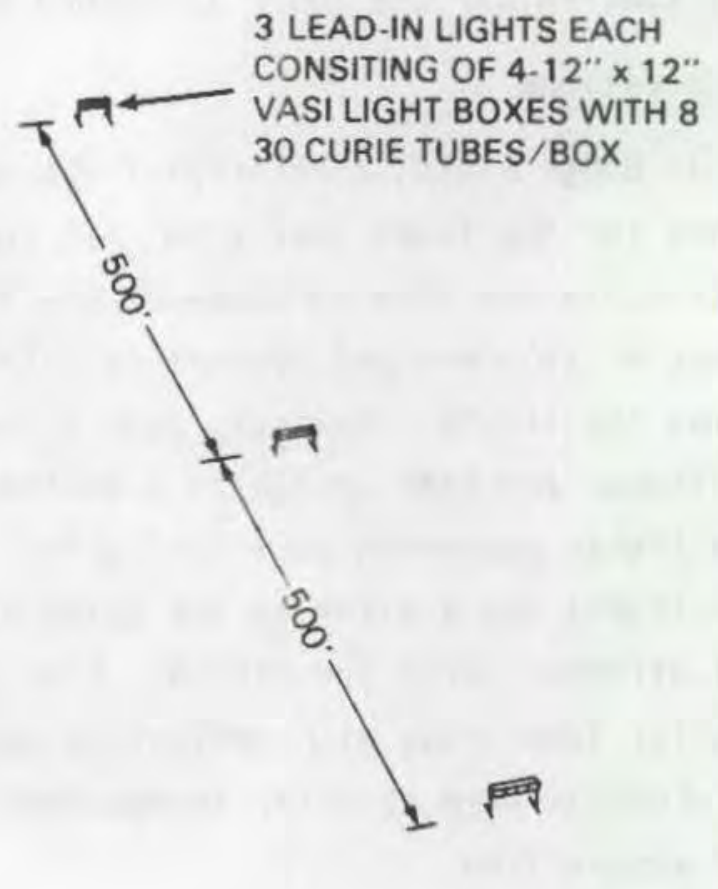

Example of a Typical Edge Light

FIGURE 3.4. RL Runway Lighting Configuration as Used at "Brimfrost $83^{\text {" }}$ and "Malamute Landing Zone 83 " 


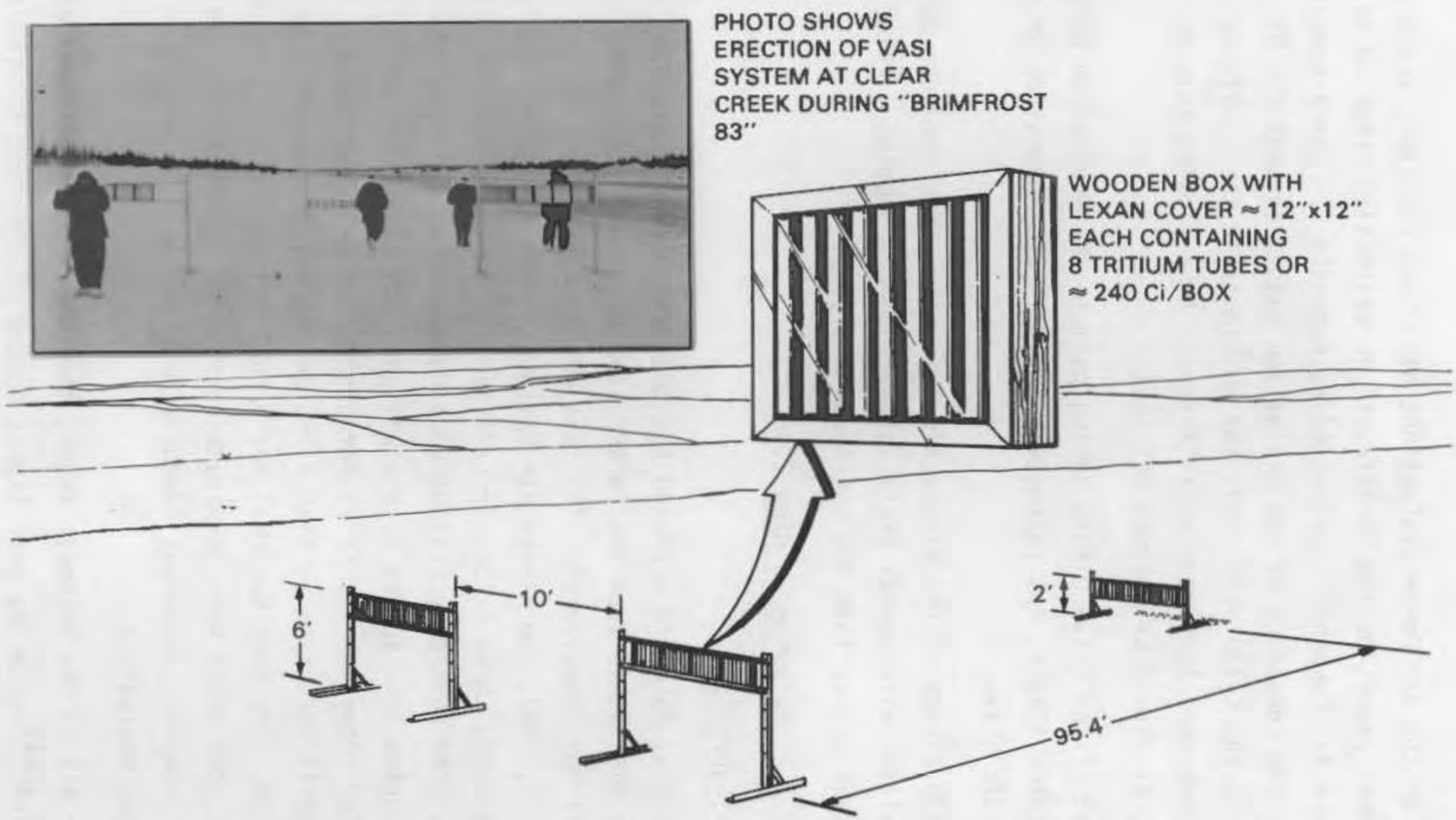

FIGURE 3.5. RL Visual Approach Slope Indicator (VASI) 
results of the Air Force evaluations have been reported, and a copy of the operational report on the "Brimfrost" RL evaluation prepared by Major Hult of the Alaska Air Command is presented as Appendix $E$. For a number of possible reasons, the consensus of the evaluation suggested that for Military Airlift Command (using $\mathrm{C}-130$ aircraft), the RL lights in the configuration used at Clear Creek were less than satisfactory. As a closing note to this test, however, it should be pointed out that:

1. Most of the $C-130$ pilots taking part in the evaluation were from outside Alaska, not intimately familiar with operation in remote Arctic areas.

2. C-130 pilots of the Alaska Air National Guard, who were more familiar with remote Arctic operations and problems, rated the system higher than the non-Alaskan pilots.

\subsubsection{Malamute Landing Zone}

\section{Configuration}

Tests at Malamute produced the greatest body of data from which to evaluate the lights from the DOT\&PF standpoint and their effectiveness and the potential for improvement. The test period was short. On the evening of February 5, 1983, the Alaska Air National Guard flew about 231 andings and takeoffs using three $\mathrm{C}-130$ aircraft as part of their routine training program. The next observations were conducted on the evening of February 7 , 1983. During this series of evaluations, low approaches were flown over the RL lighted runway by Air Force personnel in a C-12 (Beech King Air). Landings and takeoffs were made by Alaska region FAA Flight Standards personnel in a Cessna 206. The Army National Guard UH-1 helicopter was also used. On this occasion, the tests were terminated early due to onset of a heavy snow shower. However, there was adequate data acquired to result in a most meaningful evaluation.

For all of the Malamute tests, the runway was configured as shown in Figure $3.4^{(44)}$ with the edge lights spaced at 200 -foot intervals. The lighting configuration was fundamentally that of the Brimfrost tests with the addition of a wind direction indicator as shown in Figure 3.6. Each of 


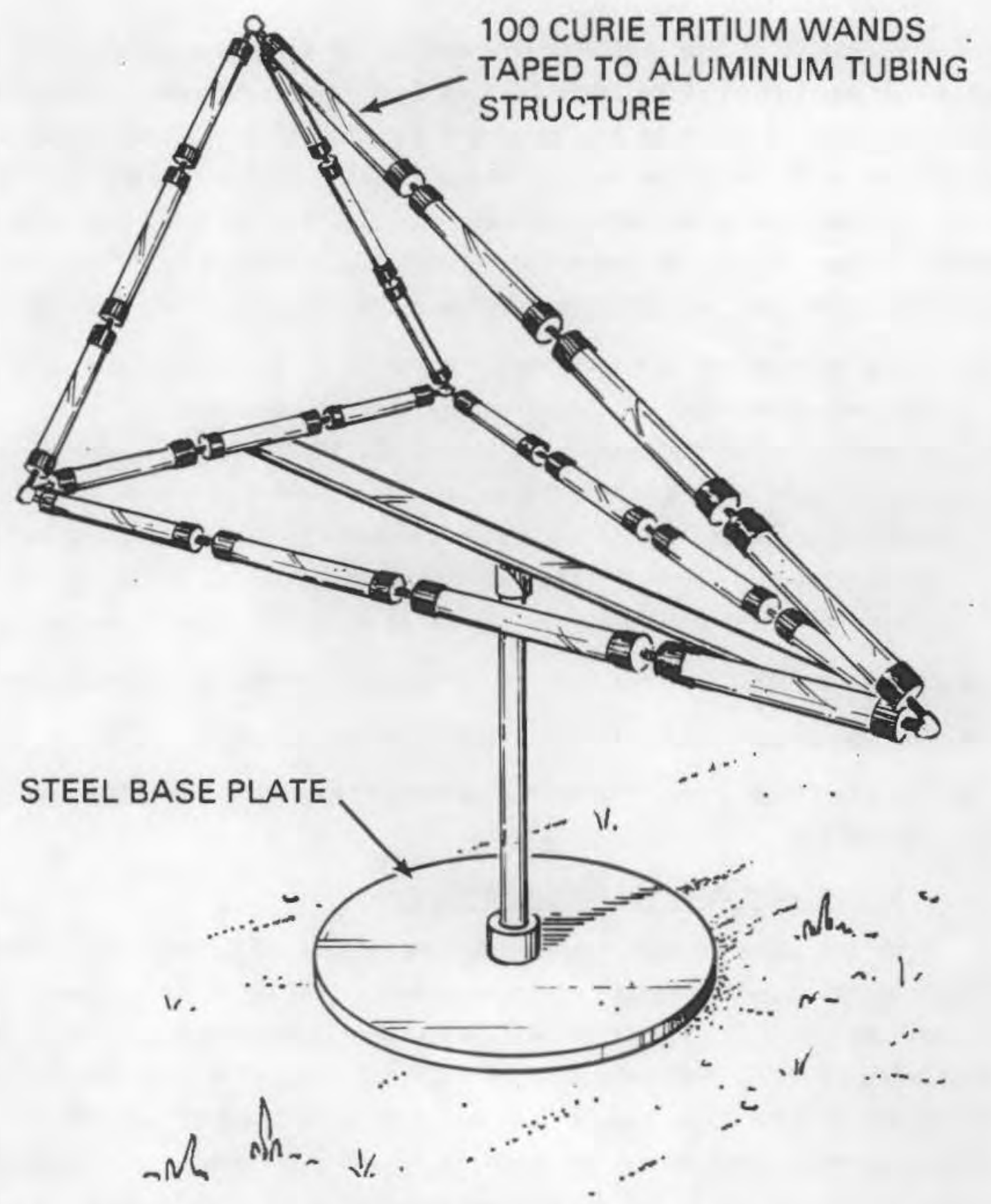

FIGURE 3.6. Wind Direction Indicator Used at "Malamute 83 " Tests 
the observers who took part in the Malamute tests were asked to complete a questionnaire. A sample questionnaire and the summary of the evaluation are presented as Appendix F.

Observations

The results of the questionnaire evaluation clearly suggested that the RL system as configured at Malamute Landing Zone held considerable potential for rural airports of the type now owned and operated by the State of Alaska. The evaluation also identified several areas in which design changes were needed in the system. After a debriefing held at Kul is Air National Guard Base by DOT\&PF on February 8, 1983, general agreement was reached by DOT\&PF and PNL/ORNL staff that the following system design changes were required.

- Since tritium was the most costly material in the system and since the amount of light emitted from the fixture was roughly proportional to the tritium it contained, the threshold fixtures should contain more tritium than the edge light fixtures. This would concentrate the light around the ends of the runway, enhancing visibility and improving the ability of the pilot to align the aircraft with the runway. This idea is illustrated in Figure 3.7.

- The wind direction indicator would need to be completely redesigned.

- The use of reflectors in the light fixtures should be tested.

- The FAA filed a report with the regional Chief of Flight Standards, Appendix G.

\subsubsection{Second Generation Prototype Development}

From the above fundamental design conclusions, ORNL began a concentrated effort to redesign the system with the primary goal being to increase the distance at which the lights could be seen from approaching aircraft. During the spring of 1983, ORNL experimented with polished metal reflectors. A redesigned tritium tube, Figure 3.8, was placed in front of parabolic reflectors in a panel array, as shown in Figure 3.9; or were configured as single units. Based on the assumption that reflector panels would be used in the threshold regions of the runway, Alaska DOT\&PF research staff suggested a 


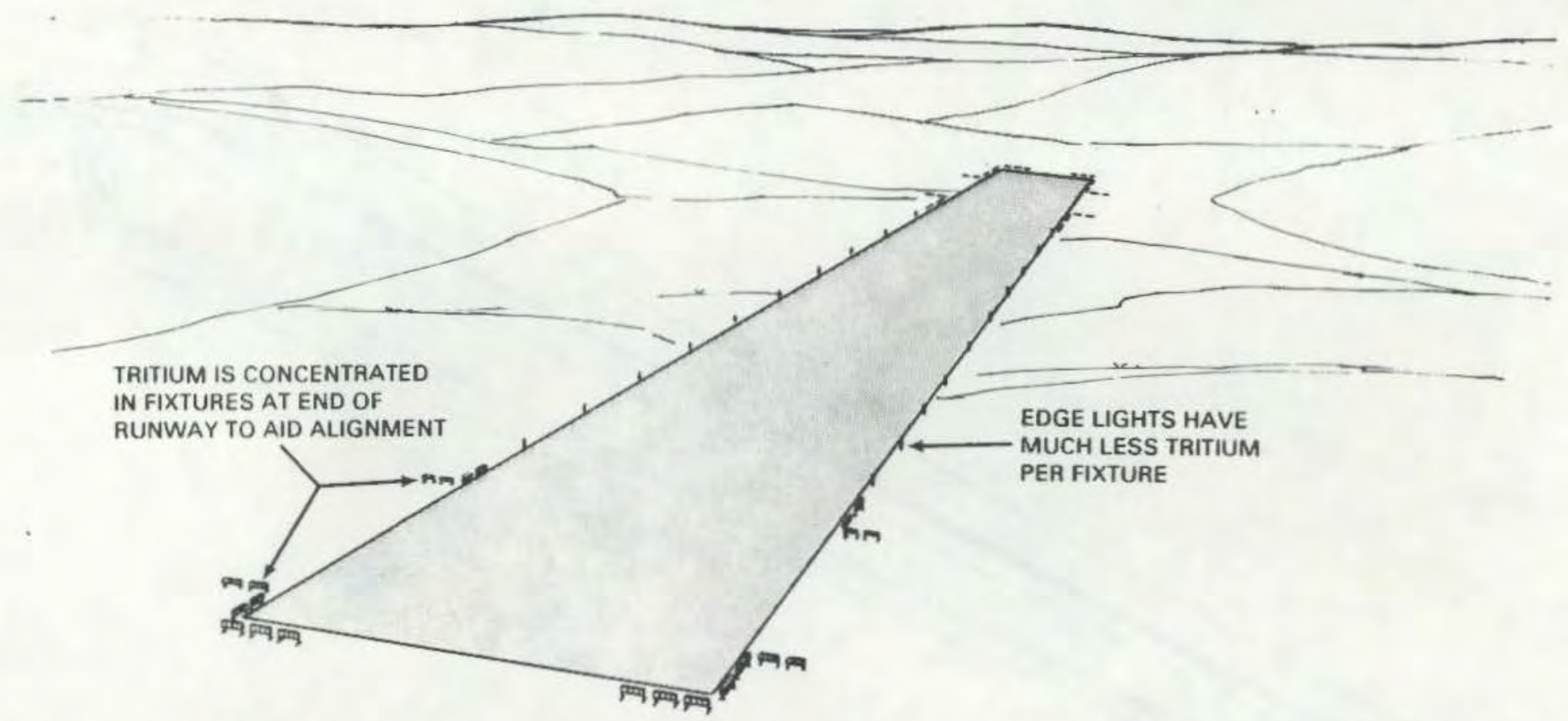

FIGURE 3.7. Conceptual RL Runway Lighting Configuration Based on MAC 55-130. Edge lights use 1 panel, 483 curies of tritium, while threshold areas use 4 or 5 panels per fixture, 1932 to 2415 curies of tritium. 


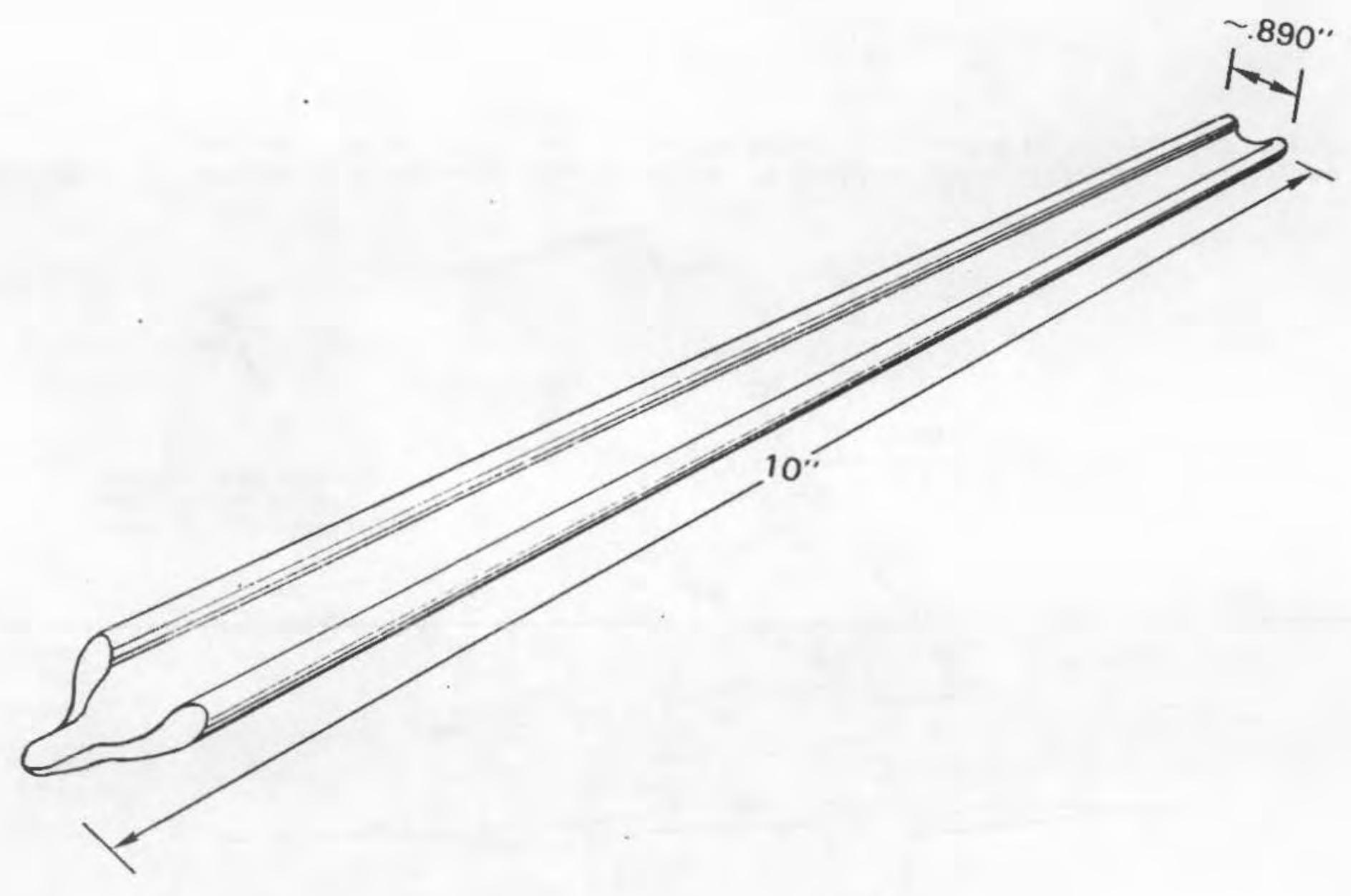

FIGURE 3.8. Tritium Tube for Second Generation Units 


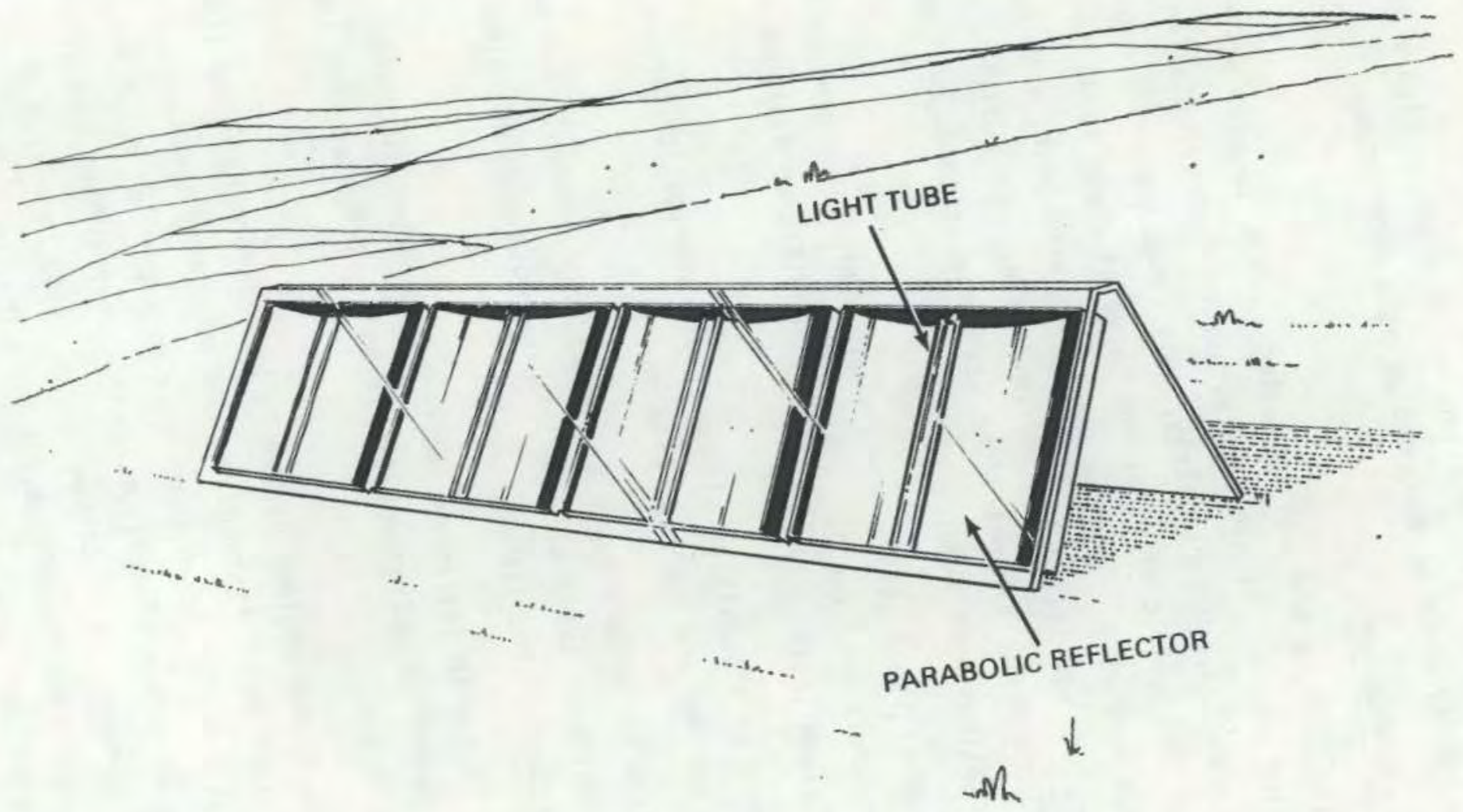

FIGURE 3.9. Redesigned $P$ anels in Panel Array 
design scheme conforming to the lighting layout shown in Figure 3.7 in which the ends of the runway would be enhanced using a panel array.

\section{Preliminary Evaluation}

On August 19, 1983, a test was conducted at ORNL to evaluate the parabolic reflector panels. It had been estimated from calculations that 4 to 6 miles could be expected. Unfortunately, this range was not achieved. For the tests, several threshold configurations based on those shown in Figures 3.2 and 3.4 were used. Weather conditions were poor, with haze, broken cloud cover, and visibility limited to 3 miles. In addition, moonlight illumination was 75 percent. Ambient light was variable throughout the test. The following observations were made:

- Acquisition of the lights was not significantly improved using the reflector panels over the 2- to 3-mile acquisition distance found in earlier Alaskan tests.

- No difference in acquisition distance was observed for panels used in Alaskan testing and the new reflector panels.

- The use of the reflectors makes alignment very critical, and the lights fade whenever exact alignment is not obtained regardless of viewed distance from the lights.

- The improved tube with its increased tritium content, improved phosphor and geometric design was significantly brighter than the earlier tubes tested.

Following this test, it was decided by the Technical Working Group (TWG) that ORNL needed to construct panel fixtures using a modular element, as shown in Figure 3.10, as the basic unit. Seven tubes were used per $12^{\prime \prime} \times 12^{\prime \prime}$ module with each tube containing 69 curies of tritium. White polystyrene insulation was used as the reflector element. A prototype system using this type of basic element was evaluated at Camp Mackal1, North Carolina, on September 7 , 1983. At that test, observers were able to acquire the lighting system at a distance of 4 to 6 miles. A summary of these observations was prepared by Lieutenant Colonel Everett and is presented as Appendix $\mathrm{H}$. 


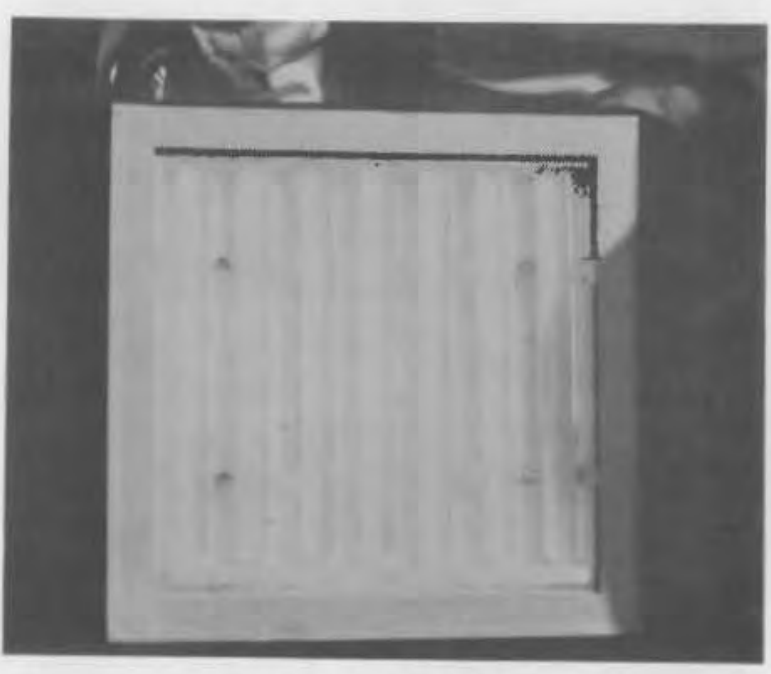

PHOTO OF PANEL

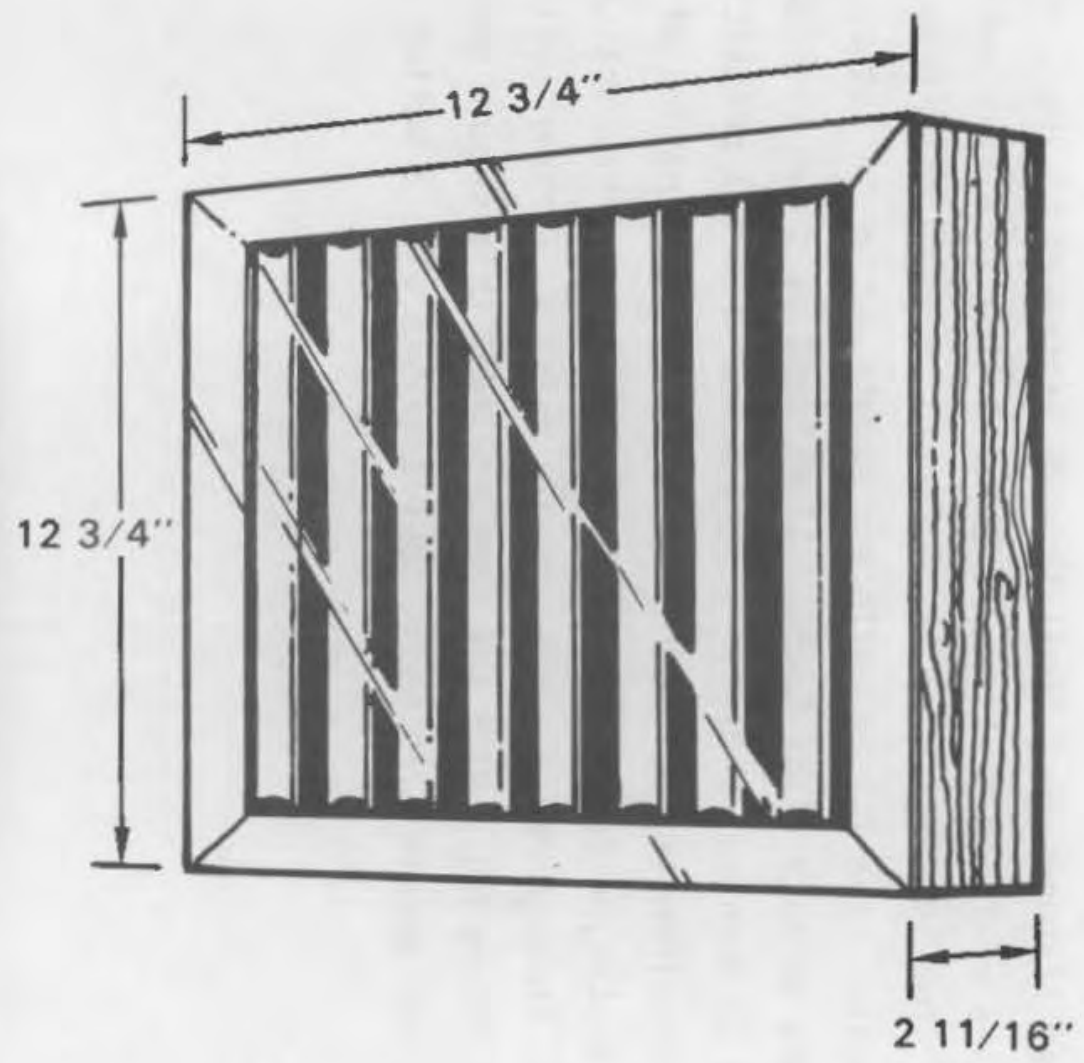

FIGURE 3.10. Second Generation Panel 
Based on the results of the developments of various fixtures and the evaluations of these fixtures from April through September of 1983, it was decided that a series of field tests would be conducted in Alaska during the winter of 1983-84. The systems to be tested would be configured from two bas ic fixture elements: the 7-tube reflector module, shown in Figure 3.10, for panel arrays and an edge light-taxiway light unit as shown in Figure 3.11. Panel arrays would be mounted, shown in Figure 3.12. For all practical purposes then, these elements would effectively be the culmination of the second generation prototype development. Tests and evaluations anticipated for December, 1983, through March, 1984, should point to further refinements in fixture design, if needed. With the completion of this second generation development, it is now possible to begin cost analysis with a better degree of confidence. 


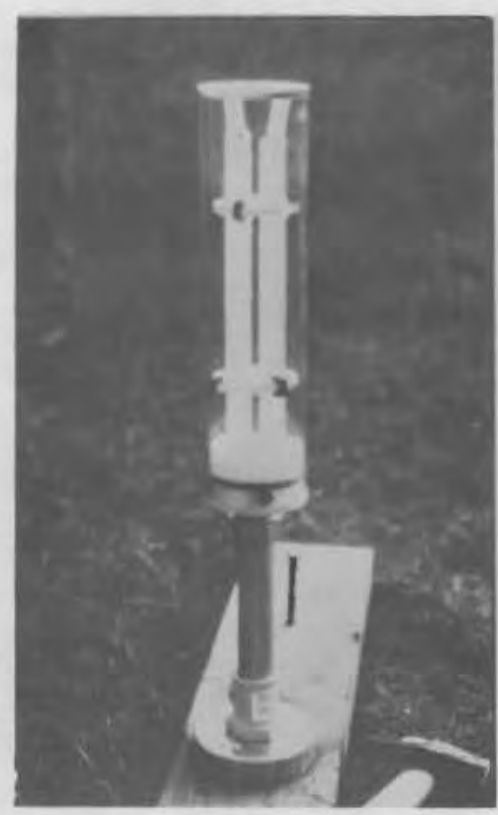

PHOTO OF EDI

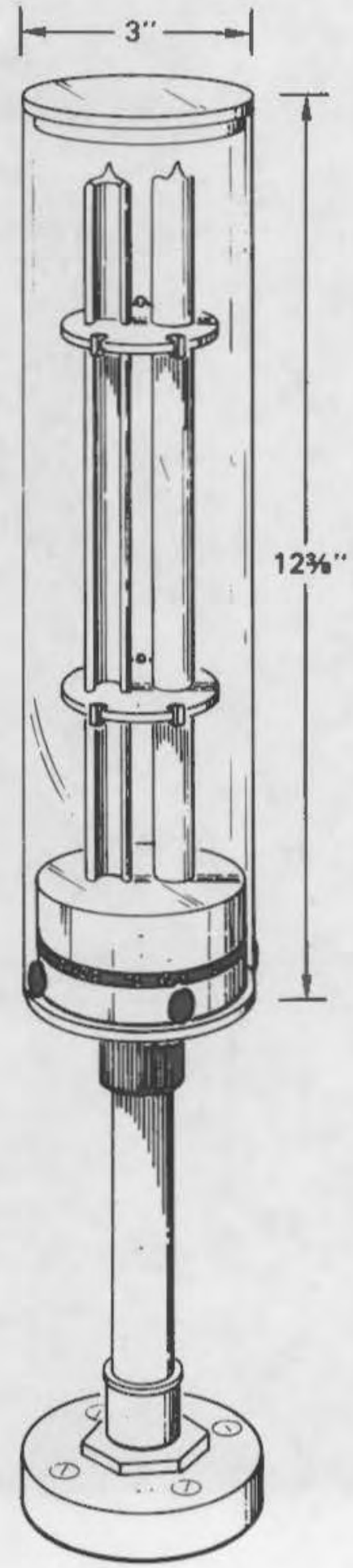

FIGURE 3.11. Edge Light - Taxiway Light 


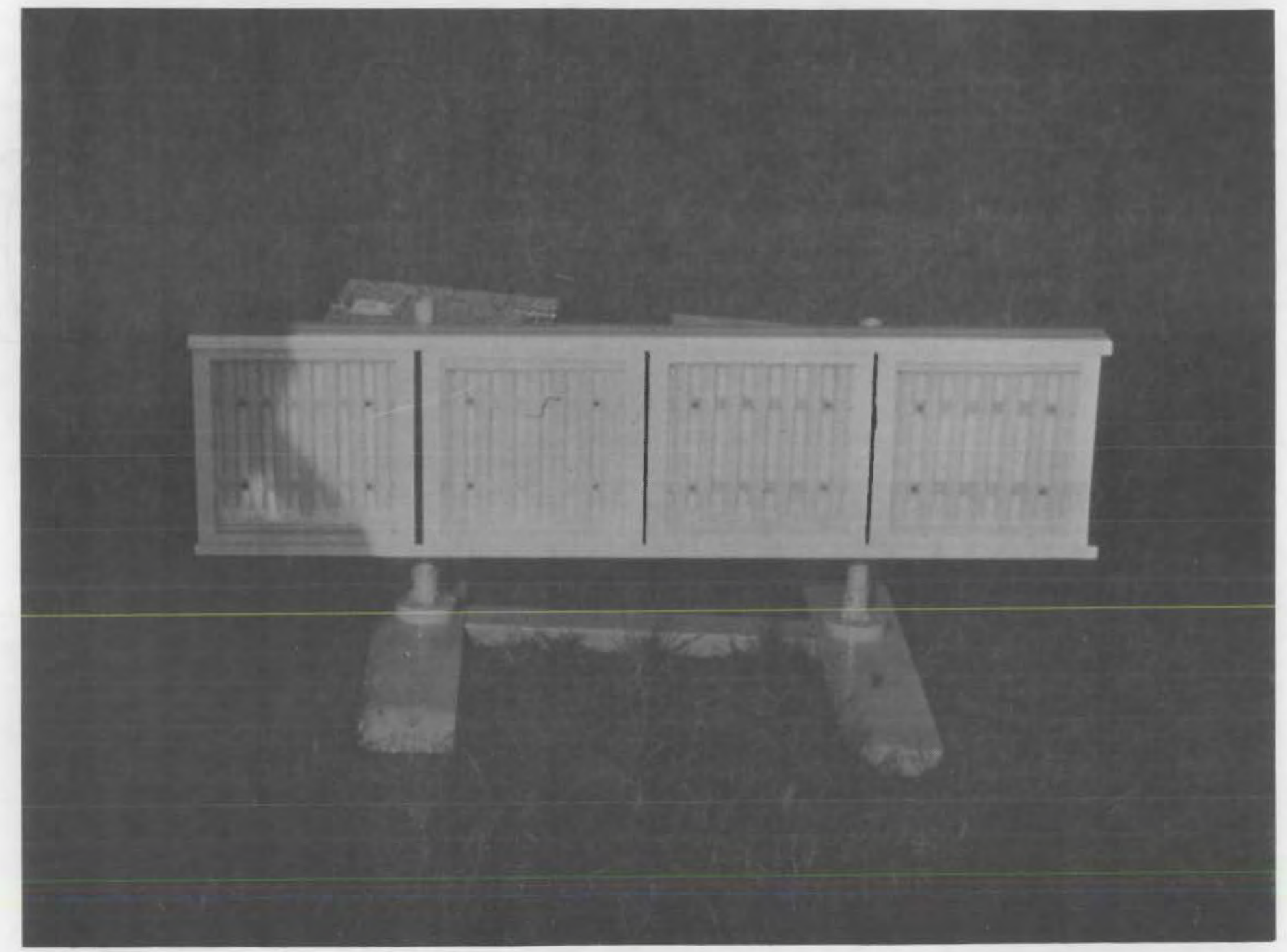

FIGURE 3.12. Panel Arrays 


\subsection{COST ANALYSIS}

\subsection{COST OF MANUFACTURE}

Manufacture of tritium lights for airfield lighting applications has been confined to ORNL as part of a research and development project. Therefore, all costs discussed in this section will be based on real costs incurred at ORNL for the manufacture of the lighting element of the type to be used for the 1983-84 demonstrations and shown in Figures 3.11 and 3.12. It is anticipated, however, that the lighting elements for operational systems would be manufactured by private industry. At this writing, it is not known how the costs incurred at ORNL would relate to those of a commercial manufacturer. Discussions with potential manufacturers and ORNL staff have suggested certain variations in costs might exist. These speculations will be mentioned in this section, but only the costs obtained from ORNL are included.

\subsubsection{Tritium}

The most expensive single material contained in any set of RL runway lights is the tritium, and it is expected to remain that way for the foreseeable future. At this time, the only source of tritium with in the United States is the Isotopes Distribution Center at ORNL. . The current cost to the existing tritium light industry is approximately $\$ 1.10$ per curie.

\subsubsection{Light Elements}

The fundamental component of all RL runway light fixtures which make up the second generation system is the tritium tube, shown in Figure 3.8. This item is the only nonconventional portion of the system. Ancillary nardware to support, contain, mount, and house these tubes in various configurations are fabricated from commercial materials. The cost of these fixturing materials are not expected to comprise the biggest expense of the airfield lighting package. At this point, it is anticipated that the cost of a single tritium tube would be as follows: 
Tritium Tube Cost*

- Tritium 66 curies/tube $(\$ 1.10 / \mathrm{C} i) \quad \$ 72.60$

- Pyrex glass specially formed $\quad 15.00$ (as per Figure 4.1)

- Phosphor 1.00

$\begin{array}{ll}\text { - Labor to prepare and load } & \\ \text { phosphor and tritium } & 15.00\end{array}$

- Quality Assurance, Testing 20.00

- total COST $\$ 123.60$

* Personal communication from ORNL personnel on several occasions.

\subsubsection{Edge and Threshold Lights}

Some manufacturers have indicated that the costs for materials, fabrication, overhead, etc., would typically be 25 to 30 percent of the costs of handling and filling the tubes. This does not strictly agree with the ORNL estimate above, but either way it is clear that the cost of tritium is the critical factor in the price of the tube. The cost of the materials, fabrication, and assembly of the fixtures that hold the tubes is estimated to be 2 to 12 percent of the cost of a completed tritium tube. This cost would vary since the cost of a fixture with fewer tubes per unit probably would cost a higher percentage than a fixture with several tubes. Therefore, an edge light fixture like the one shown in Figure $3.11 \mathrm{might} \cos t$ :

$2 \times \$ 123.60=\$ 247.20$ for two tritium tubes

$$
+\frac{12 \%}{\$ 276.86 \text { Total }}
$$

or, a $12^{\prime \prime} \times 12^{\prime \prime}$ panel module, as shown in Figure 3.12 , with 7 tubes might cost:

$7 \times \$ 123.60=\$ 865.20$ for 7 tritium tubes

$$
+\frac{2 \%}{\$ 882.50 \text { Total }}
$$

This cost is assumed to be FOB at the factory at an unspecified location in the "Lower 48 " states. 
Besides the light units themselves, the following costs are associated with lighting a rural airport.

- Transportation of lights from factory to Alaska.

- Purchase of support hardware (panels, stanchions, frangible couplings, etc.).

- Transportation within Alaska.

- Installation contract.

Shipping to Alaska will be via conventional motor freight, which at this time is approximately $\$ 90$ per $100 \mathrm{lb}$. Support hardware is conventional steel fabrication, which is typically $\$ 3$ per $1 b$. Frangible couplings are about $\$ 4$ each. Transportation within Alaska would most likely be via air freight, which in the most expensive case would require a charter of a light aircraft. Based on communications with air freight carriers in Fairbanks, the maximum transportation costs would be under $\$ 3,500$ for a set of RL 1ights with shipping containers. Installation could vary considerably based on specific location and the final design of the mounting hardware. Weather contingencies are always a problem, but the following estimate could be typical for installation:

$\begin{array}{lr}\text { *Labor - } 4 \text { men for } 6 \text { days (including travel time) } & \$ 7,200 \\ \text { Travel and per diem } & 4,600 \\ \text { Equipment rental } & 300 \\ \text { Overhead } & 5,000 \\ \text { Contingency } & 3,000 \\ \text { Profit 10\% } & 2,000 \\ \quad \text { Total } & \$ 22,100\end{array}$

* Assuming a remote location as much as 500 miles from Fairbanks or Anchorage.

Based on the above costs, let us consider three different light configurations which will be evaluated during the winter of 1983-84. The configurations are shown in Figures 4.1, 4.2, 4.3, and represent different amounts of tritium or 
UNICIRECTIONAL

TOUCHDOWN ZONE PANELS

OF 4-PANEL MODULES EACH

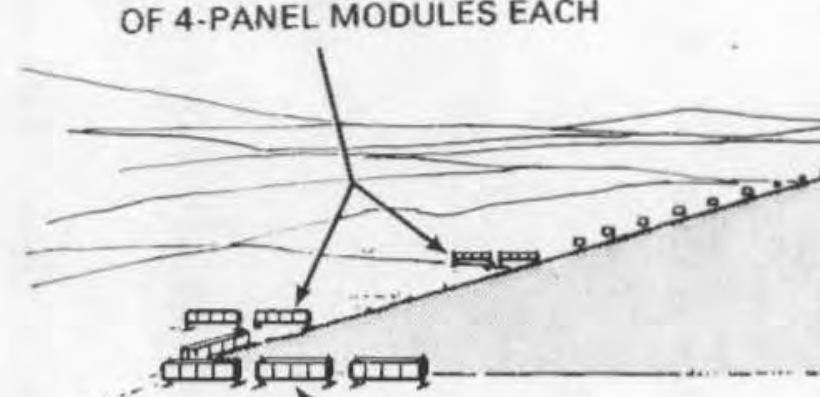

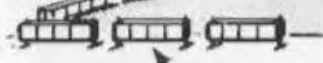

BI DIRECTIONAL

THRESHOLD MARKERS EACH

WITH 8-PANEL MODULES

FIGURE 4.1. Military MAC 55-130 Configuration
BI DIRECTIONAL

DOWNWIND MARKER

PANEL WITH 8-PANEL

MODULES

\section{EDGE LIGHT AT 200' SPACING}

OMNI DIRECTIONAL 


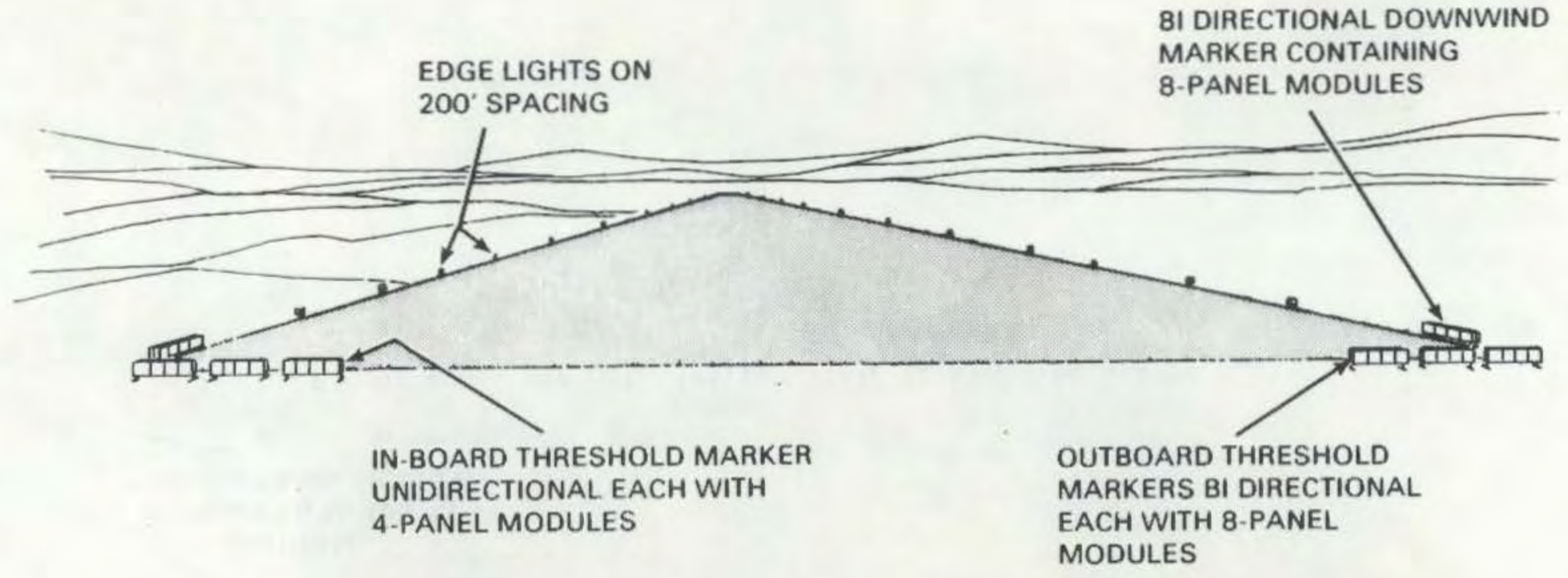

FIGURE 4.2. Civilian-Style RL Lighting System 


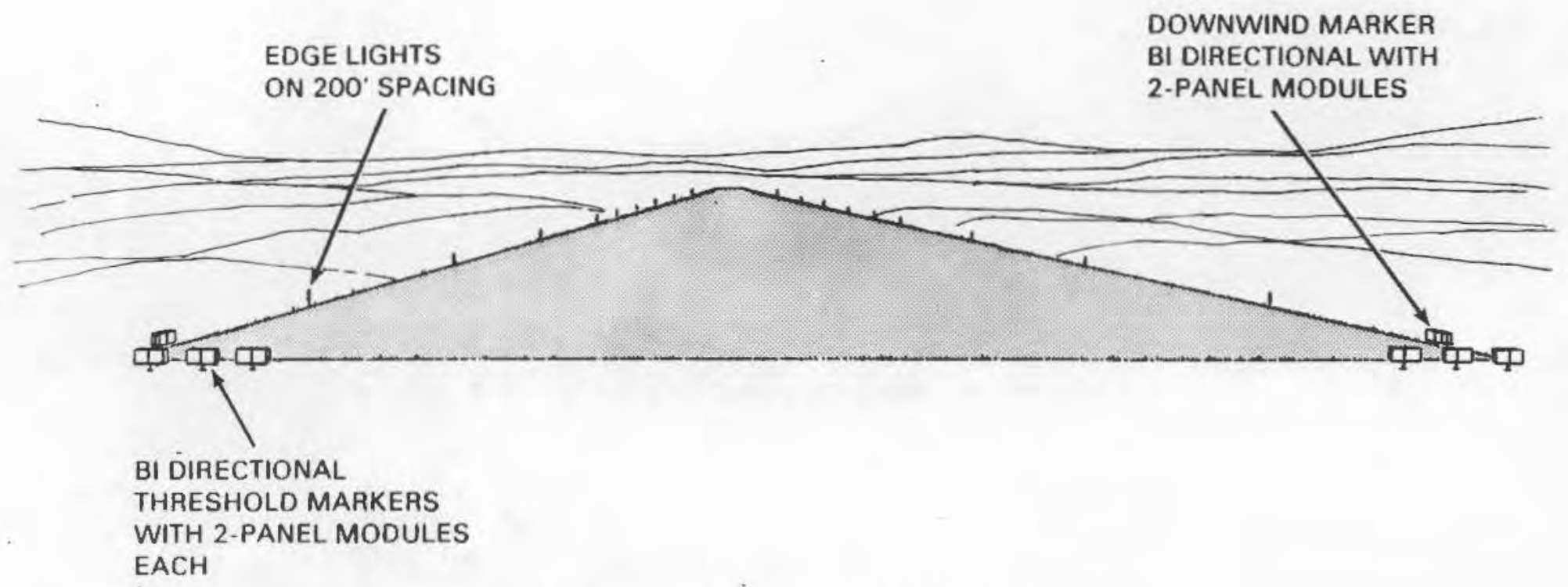

FIGURE 4.3. Minimal Civilian-Style RL Lighting System 
number of tritium tubes. The estimated cost for each and the range of costs for lighting remote Alaskan runways is shown in Table 4.1.

\subsection{MAINTENANCE}

It is still premature to discuss potential maintenance costs with any degree of certainty. The fixtures are still in a prototype stage of development, and maintenance costs can only be based on a final design. We can, however, discuss the parameters of an RL lighting system that are expected to effect maintenance costs.

\subsubsection{Energy Cost}

Since RL lights are self powered, the energy costs are included in the first cost and replacement cost. However, since the tritium continually decays, reducing the light emitted, the useful life of an RL light is finite. What this life cycle may be in practice is not known. The half-life of tritium is approximately 12 years, but depending on the gas pressure, phosphor, tube shape, etc., it is not easy to say whether or not the diminishing rate of useful light output will be directly proportional to the rate of decay in beta energy of the tritium. At this point, we can use 8 to 10 years as a life cycle for estimating purposes, but it is definitely only a rough estimate.

\subsubsection{Quality Assurance}

Since each light is a unit, it is reasonable to expect some defective units would find their way into use. The most critical factor would be a tritium leak in a light tube, which might not show up until the fixture had left the factory. Thus, quality control and quality assurance requirements need better definition. Another area of possible defect would be the phosphor and the binder with which it is attached to tube surface. Other potential defects would be related to the materials and assembly. The frequency of such defects is related to the manufacturing process and to a large degree relates to size of the market and, thus, the rate of production. These factors will effect maintenance costs, but cannot be estimated at this time. 


\section{TABLE 4.1. Cost Table}

\begin{tabular}{|c|c|c|c|c|c|c|c|}
\hline Configurations & Iritiua Curtes & Cost of Light Units & $\begin{array}{l}\text { Cost of } \\
\text { Iransportation } \\
\text { to Alaska }\end{array}$ & $\begin{array}{c}\text { Installation } \\
\text { Marcmare }\end{array}$ & $\begin{array}{c}\text { Cost of Transportation } \\
\text { to Site In Alaska }\end{array}$ & $\begin{array}{c}\text { Cost of } \\
\text { Installation }\end{array}$ & Totals \\
\hline $\begin{array}{l}\text { 1. As shown in Figure } 4.1 \\
\text { uses waC } 551301 \text { lighting } \\
\text { pattern with touch-down } \\
\text { zones delineated. Probab- } \\
\text { ly would not be used for } \\
\text { civilian application }\end{array}$ & $\begin{array}{l}1176 \text { tubes at } \\
69 \text { curies/tube } \\
\text { for } 3000 \mathrm{ft} \\
1316 \text { tubes at } \\
69 \text { curies/tube } \\
\text { for } 4000 \mathrm{ft}\end{array}$ & $\begin{array}{l}168 \text { panel modules } \\
188 \text { panel modules }\end{array}$ & motor freight & $\begin{array}{l}\text { FM approved } \\
\text { stakes and } \\
\text { coupling panel }\end{array}$ & $\begin{array}{l}\text { Chartar of Skyvan or } \\
\text { equivalent and } \$ 500 \text { in } \\
\text { conventional air } \\
\text { freight }\end{array}$ & & \\
\hline 3000 foot runway & $\$ 89,258$ & 5148,260 & $\$ 1.100$ & $\$, 100$ & $\$ 3,500$ & $\$ 21,800$ & $\$ 178,760$ \\
\hline 4000 foot runway & 599.884 & 5165,910 & 81,200 & 5,260 & $\$ 3,500$ & $\$ 22,100$ & 5196,970 \\
\hline $\begin{array}{l}\text { 2. As shown in figure } 4.2 \\
\text { similar configuration to } \\
\text { II above, however, no } \\
\text { touch-down zone deline- } \\
\text { ation as included }\end{array}$ & $\begin{array}{l}728 \text { tubes at } \\
69 \text { curies/tube } \\
\text { for } 3000 \mathrm{ft} \\
868 \text { tubes at } \\
69 \text { curies } / \mathrm{tube} \\
\text { for } 4000 \mathrm{ft}\end{array}$ & $\begin{array}{l}\text { Tou panel modules } \\
\text { and panel edge } \\
\text { lights } \\
\text { i24 panel modules } \\
\text { and panel edge } \\
\text { lights }\end{array}$ & motor freight & $\begin{array}{l}\text { FWh approved } \\
\text { stakes and } \\
\text { coupling panel } \\
\text { racks at } \$ 60 \\
\text { each }\end{array}$ & Charter of Skyvan & & \\
\hline 3000 foot runway & 555,355 & 591,780 & 5900 & 72,90 & $\$ 3,000$ & 520,800 & $\$ 119,390$ \\
\hline 4000 foot rumway & $\$ 65,881$ & 5109,430 & 51,000 & $\$ 3.050$ & $\$ 3,000$ & $\$ 21,100$ & 5137.650 \\
\hline $\begin{array}{l}\text { 3. As shown in Figure } 4.3 \\
75 \% \text { of the threshold } \\
\text { illumination has been } \\
\text { removed. Edge } 1 \text { ighting } \\
\text { is the same as } \$ 2 \text { above }\end{array}$ & $\begin{array}{l}468 \text { tubes at } \\
69 \text { curles/tube } \\
\text { for } 3000 \mathrm{ft} \\
508 \text { tubes at } \\
69 \text { curies/tube } \\
\text { for } 4000 \mathrm{ft}\end{array}$ & $\begin{array}{l}64 \text { panel modutes } \\
\text { and } 20 \text { edge } 1 \text { ights } \\
64 \text { panel modules } \\
\text { and } 30 \text { edge lights }\end{array}$ & motor Freight & $\begin{array}{l}\text { FMA approved } \\
\text { stakes and } \\
\text { coupling panel } \\
\text { racks at \$20 } \\
\text { each }\end{array}$ & $\begin{array}{l}\text { Charter of piper } \\
\text { Havajo Chieftain }\end{array}$ & & \\
\hline 3000 root runway & 535,521 & $\$ 52,017$ & 5400 & $\$ 1.070$ & 52,200 & 519,800 & $\$ 85,577$ \\
\hline 4000 foot runway & 338,557 & 564,785 & $\$ 500$ & $\$ 1,220$ & $\$ 2,200$ & 520,000 & $\$ 88,705$ \\
\hline
\end{tabular}




\subsubsection{Breakage}

It Is anticipated that the single greatest factor influencing the maintenance cost of an RL $5 y$ tem would be the cost of replacenent of units that are broken as a result of accident, vandalism and/or theft. Again, it is not possible at this the to es timate these factors before we have gainet some field experience in a user environment.

\subsection{PRELIMINARY LCC ANALYSIS AND COST-BENEFIT CALCULATIONS CONPARING CONVENTIONAL SYSTEMS}

\subsubsection{Sumary of Cost Factors}

Based on the above, it would appear that an RL system could be developed that would be competitive with conventional lighting systems in first cost and should result in considerable operating (total) cost savings over conventional systems. Installation costs for a medium intensity lighting system for a $2520 \mathrm{ft}$ runway at Birch Creek, Alaska, are estimated at $\$ 265,000$. Typical costs for conventional medium intensity lighting systems in Alaska range from a low of $\$ 100,000$ to a high near $\$ 300,000$. Thus, cos $\$$ when compared to the cost of configuration number 2. Table 4. 1 , which is expected to be a typlat configuration, is expected to be nearly twice the cost of the RL Iight systera. Wile maintenance costs cannot be estinated with a satisfactory level of accuracy at this tine, there is every reason to expect that continuing cost for both maintenance and operations would not exceed those for conventional systems.

\section{$4,3.2$ Visual Approach Slope Indicator (VA51)}

An RL visual approach slope indicator (VASI) can be considered as an option to the basic system. Since a typical UASI would require a minimum of 9 panel modules, the greates portion of the cost would be the light panels at \$7942. It is reasonable, therefore, to assume that mounting hardware and installation fif included as part of the edge and threshola light installation might add an additional $\$ 600$ to this. Therefore, assume the cost of a VASI would be approximately $\$ 8500$. 


\subsubsection{Wind Direction Indicator}

At this time there are not enough test data or design information on a wind direction indicator to develop a realistic cost estinate. 


\subsection{CONCLUSZONS}

Radioluminescent (RL) lights have been used with some success as il lum nators to assist night landings of airoraft. This application has been identifled as a potentially valuable al ternative to firepots or $\$$ inflar nonconventional lighting at nany rural airports throughout Alaska.

RL airport illuminators are experinental at this time and are not avallable comercially; however, successful deronstrations have been made suggesting that a prototype design has been refined to a point where technology transfer to industry may be made in the near future.

Prelininary cost estimates suggest that significant cost adyantages could be posslbe for applications in rural Alaska compared to conventional Iighting systems.

Since the RL lights contain radioactive materials, there is some potential $r i s k$ that their use will result in exposure to radiation doses to humans who come into contact with them. Under normal, usage, this rist is show to be insignificant. Inder zorst-case accldent scenarios, however, it is possible that a significant dose greater than 5.0 rem could be recelved by a lint wed number of people. Generally speaking the radiological hazard, however, is expected to be mininal for this application.

Development of the RL airfield lighting system is expected to continue in the 1983-84 period with some permanent installations possible in late 1984. However, implementation of sidn systems are not expected to be possible on a routine basis prior to 1955 . 


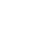

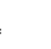

.

, 


\subsection{IMPLEMENTATION}

Radioluminescent sys tems that could be used for airport lighting applications and would be useful to the Alaska DOT\&PF are, at this time, in the process of research and development. They are not now avallable from any source other than the U.S. Department of Energy, and this availability is 1 imited to special experiments. This condtcton is not expected to change in Fy 1984. However, if the present rate of progress continues in the development of these systems, it is possible that inplementation of this technology into the routine operations of the porapf could begin in Fy 1985.

This report describes in detail the RL system and suggests that 1 ts successul development could be very beneficlal to the DorapF, the 5 tat of Alaska, and its people. If this is to happen, however, several factors must be resolved. The following is a 11st of factors that, while probably incomplete, should serve to define approximate limits for the future scope of this development effort:

1. Funding from DoTsPF to the U.S. DOE must continue in Fy 1984 and DoTgpF research staff must maintain an active level of invalvement with the DOE Program through the Technical Working Group.

2. Dot allocations from the federal budget for this progran must continue.

3. The 11 inted demonstration planned for Centrai, Alaska, during December 1983, and January 1984, must prove satisfactory to:
a. Community residents
b. Pilots and comercial air carriers
c. FAA Diviston of Flight Standards
d. DOTSPF personnel.

4. Based on evaluations and testing during the winter of 1983-84, a final design for an operational RL. system must be developed with detalled specifications.

5. DoE must begin the process of transferring the RL technology to comerctal manufacturers. 
6. DotspF ms toncourage comercial manufacturing firms to produce lights as part of their product line and to apply for a general license on those products from the NRC.

7. If potential markets for Rl. airport lighting appear to be too small to interest the existing tritium light industry, then the State of Alaska may consider applying for the license and arrange for manufacture within the state.

8. The Alaska Region of the FAA must develop adequate policies and procedures to permit the incorporation of RL airport lights into routine use in Alaska for afr taxi operations under Part 135 FAR.

If, by the suamer of 1984, items 1 through 4 above are found to have been favorably resolved, then we recommend for consideration a demonstration installation at an appropriate location in Alaska. This location would serve as a permanent field test in a user environment from which da ta could continualiy be gathered to support the resolution of $i$ tems 5 through 8 . Al though this installation would not be a truly routine operational system, it *ould be a permanent prototype and could become the final stepping stone toward full implementation. 


\subsection{REFERENCES}

1. "Renote Airport Lighting Systems Feasibility Report and Design Guide." State of Alaska, Department of Transportation and Public Facilities, Research, Fairbanks, Alaska.

2. Strobe Linhting Demons tration Project at St. Michael, Alaska. 1980. keport No. AK-R0-80-5, State of Alaska, Department of Transportation and Public Facilities, Research, Fairbanks, Alaska.

3. Wince, Corthell, Bryson, Freas, consul ting engineers in association with Arctic Consulting Engineers. 1981. Rural Airport Lighting, Resources and conditions I nventory, State of Alaska, Department of Transportaton and PubTic Facilities * Planning and Programing, February, 1981.

4. Ikeda, M., T. Yanagi, and Y. Shjnozaki. 1966. "Measurement of Leakage Tritiun fron Tritiun self-luminous paints." Radioisotopes, Metropol. Isotope Res. Center, Tokyo 15, Japan, 19-22.

5. Wlison, E. J., J. D. H. Hughes. 1960, "Light Sources Using Radiolsotopes." Contenporary Phys. 1, No. 1, 62-9.

6. "AEC Exempts Tritium and Promethium and Increases Tritium Limit," Isotopes and Radiation Technology, 4(3):306, 1967.

7. Niemeyer, R, A. 1970. "Tritium Loss from Tritium Self-Luminous Aircraft Exit Signs," Isotopes and Radiation Technology, 7(3):349-352.

8. Korin, A., and M. Givon. 1975. "Paraneters Affecting the Intensity of Light Sources Powered by Tritium, "Nuclear Instruments and Methods. $130(2): 231-237$.

9. Eggers, P. E., and W. E. Gaw throp. 1975. An Assessment of the Potentialiy Beneficial Uses of Krypton-85 Finat Report Task $6 \times$ BMI-X-660, Battelle Columbus Laboratories, Columbus, $O H$.

10. Thouret, W. E., R. Kaufman, and U. W. Orlando. 1975. "Energy and cost Saving Krypton Filled Incandescent Lamps," 3. I11um. Eng. Soc.* 4:3, p. 188-197, Apri1 1975 .

11. De Bie, J. R., J. C. M. A. Ponstoen. 1977. "Life and Luninous Flux of Halogen Incadescent Larnos Related to Filament Temperature, Pressure and Che $8 r_{2}$ Content," Light Res. Technol. (United Kingdom) 9:3, p. 141-150.

12. Ristagno, C. V., A. A. Moghissi, P. Paras, M. W. Carter, and R. F. Barker. 1978. "Use of Tritium Luminous Sources for Lighting Digital Wristwatches Radioactivity in Consumer Products, "Micro Display Systens, Inc., Dallas, TX. for Nuclear Regulatory Commission. Washington, D.C., Augus 1978. p. $320-322$. 
13. Zielenbach, H. 3. 1978. "Studtes of Beneficial Energy Applicatons for Krypton-35, Task 83, Final Report" BMI- $x-697$, Battelle Columbus Laboratories, Columbus, OH, September 30, 1978, p. 97.

14. 01x, G. P. 1979. "Recycle Nuclear Waste: Why Not," Energy, Stanford, CT, $4: 1$, p. $23-24$.

15. Niemeyer, R* G. 1969. Tritum Loss From Tritium Self-Luminous Aircraft Exit signs, ORNL-TM-2539. Oak Rifge National Laboratory, Oak Rrage. Tennessee.

16. Lederar, C. M. and Shiriey, V. S., eds. 1978. Table of Isotopes. 7 th ed. Wiley-Interscience. New York, NY.

17. General Electric. 1977. Table of Isotopes. San Jose, California.

18. Case, F. N., and W. C. Remint. 1980. "Radiolsotope Powered light Sources," paper presentad at Arroort Lighting Society of North Anerican Heeting, Novenber 1960 .

19. Case, F. N., and K. W. Haff, 1981. "Krypton-85 Powered Lights for Airfield Application." AFESC/ESL-TR-80-55, prepared for Air Force Engineering and Services Center, Tyndall AFB, FL, by Operations Oivision, Oak Ridge National Laboratory, Oak Ridge, TN 37830.

20. Haff, K. W, F. H. Case, F, J, Schultz, and J. A. Tompkins. 1981. Testing of Tritium-Powered Runway Distance and Taxiway Markers. ESL-TK-8T-45, prepared for Air Force Engineering and Services center, Tyndall AFE, FL, by Operations Division, Oak Ridge National Laboratory, Dak Ridge, TH 37830 .

21. Case, F, N., $W_{*}$ C. Kemini, and R, E. Nelson. 1982. "Current Development in Radionuclide Light Production," Trans. Ar. Nucl, Soc., Vol. 43, p. 89-90, prepared for American Nuctear Society T982 Winter meeting, Nov. 14-18, 1982, Washington, D.C.

22. Tingey, G, L., G. A. Jensen, E. D. Mcclanahan, J. M. Lytle, and K. H* Rising. 1983. "Potential for Beneficial Use of Krypton-85," PNL-SAm-10832, Pacifle Northwest Laboratory, Richland, WA, prepared for presentation at Waste Management Conference, Tucson, AZ, February 27 , 1983.

23. Schoolsy, L. C, and J. A. Regan. 1980. "Visibility and Legibility of Exit Signs. Part I: Analytical Prediction." Journal of the Illuminating Engineering Society, October 1980, "24-28.

24. Schoolsy, L. C., and J. A. Regan. 1980. "Visibility and Legibility of Exit signs. Part il: Experimental Results. Joumal of the 111 uminating Engineering Society, October $1900,24-28$. 
25. Kocher, 0. C, (ed.). 1977. Nuclear Decay Data for Radionuclides occurring in Routine Releases from Nuctear Fuel Cycle Facitities, ORN NDREG TIMTOT.

26. Berger, M. J. 1971. Distribution of Absorbed Dose Around Point Sources of Electrons and Beta Particles in Water and other Media. J. NucT. Med., 12. Supplentent No. 5 :

27. U.S. Public Heal th Services, Consumer Protection and Environmental Heal th Service. 1970. Radiological Heal th Handoook. Bureau of Radiological Heal th and Training Institute, Rev. Ed. Environmental Control Administration, Government Printing Office.

28. Bloom, $W$, and Fawcett, D. W. 1975. A Textbook of His tolog. W. B. Saunders Company, Philadelphia, Pennsylvania.

29. Goss, C. M, ed. 1973. Gray's Anatomy, Lea and Febiger, Philadelphia, Pennsylvania.

30. Jensen, 0. 1976. The Principle of Physiology. Appleton-Century-Crafts, New York.

31. International Comission on Radiation Protection (ICRP). 1979. Linits for Intakes of Radionuclides by Workers. ICRP Publication 30, Supptement to Part T, Pergamon Press. Wew York, W.

32. International Conmission on Radiation Protection (ICRP). 1979. Limits for Intakes of Radionuclides by Workers. ICRP Publication 30, Part ?. Pergamon Press. New York, NY.

33. Mchelis, D, N., A, A. Moghisti, R, G. Patrzer and R. C. McMilian. 1972. "Tritium Body Burden of Swine Following the Rupture of a Luminous Source Activated with Elemental Tritium." Health Phys. 22(2):161-164.

34. Nuclear Regulatory Comission. 1979. Atmospheric Dispersion Models for Potential Accident Consequence Assessments of Nuclear Power PTants. Regulatory Guide I.T45.

35. U.S. Code, Title 10, Section 30-35.

36. U.5. Nuclear Regulatory Comission. March 1979. "Guide for Preparation of Applications for Licenses for Laboratory and Industrial Use of Small Qyantities of Byproduct Material," Regulatory Guide 10.7. Washington, D.C.

37. U. 3. Department of Comerce/National Bureau of Standards. 1976. American National Standard N540 tlassification of Radioactive Sel f-Luminous Light Sources, N8S Handbook 116. Washington, 0.C.

38. U.5. Code, Title 49, Section 100-199. 
39. $N$ NREG/CR-1263 (5.2).

40. Rank in, W., Melber, B., Overcast, T., and Nealey, S. 1981. "Nuclear Power and the Public: An Update of Collected Survey Research on Nuclear Power," December.

41. Nealey, 5., and Radford, L. 1978. Public Pol icy Issues in Nuclear Was te Mana gement:

42. Lym, J, Wyat, R., Gaines, J., Pearce, R., and Yanden Bergh, B. 1978. "How Source Affects public Service Advertising, Journalism ouarterly. Winter, $716-720$.

43. Pinscak, R, 1983, "Mass Comunication and Persuaston," Unpublished manuseript, HARC/Batelle.

44. Military Air Transport Comand Regulation. August 1982. MACR 55-130, Chapter 5 . 


\subsection{PATENTS}

McCoy, M. W. "Self-iuminous Lighting System," U.S. Patent 4,285,029, April, 1979.

Aul $t, j, 0$, "Luminescent hatertals Producing a La Radiation Level, "Brtt. Patent 1,016,902, January, 1966.

Gloeilampenfabrieken, $H . \forall$. Philips', "Luminescent Substances, "French Patent $1,400,941$, May, 1965 .

Kazank in, 0. N., and M. A. Dikhter, "Phosphor," U.S.S.R. Patent 176,343, November, 1965.

Machlutchin, J. G., D. B. Cowan, I, W. All am, and $w$. H, Byler,

"Tritiumactivated Self-luminous Compositions," U. $\mathrm{J}_{*}$ atent $3,224,978$, Decenber, 1965.

Feuer, 1." "Self-luminous Tritiun Light Sources, U. 4 . Patent 3,478,209, November, 1969.

Thueler, 0. W., "Tubular, Radioactive Light Sources," Swiss Patent 495,529, Octaber, 1970.

Wes to, G. H., "Luminescent Lamp," German Patent 1,076,270, February, 1960 .

MacWood, G. E., G. D. Wilder, and D. Al tman, "Recovery of Uranium from Calutron Wash Solutions, U. U. Patent 2,879,130, March, 1959.

Lange, K. W. "Luminescent Materials," Swiss Patent 333,181, Novenber 1958.

De Leo, F. R., and E. Shapiro, "Self-lumi nous Paints " U.S. Patent $3,033,797$, May, 1962.

General Telephone \& Electronics Laboratories. Inc* "Copper Activated Electrliminescent Phosphor," British Patent 1,003,859, September, 1965.

Zeller, A, "A Self-luminating Phosphor," British Patent $1,002,426$, August, 1965.

Krah, H., G. Graeber, E. Barth, and L. Kiel, "Electroluminescent Phosphors," German (East) Patent 36, 244, May, 1965.

Wachtel, A., "Thallium-activated Zinc Sulfide Phosphors," U.S. Patent $3,210,290$, October, 1965.

Wes to, G. H. "Self-ill uminating Substances," Geman Patent 1,139,595, Novenber 1962. 


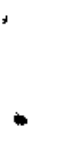

. 
APPENDIX A

IMPROVED TRITIUM RADIOLUMINESCENT (RL) AIRFIELD LIGHTING

DEVELOPMENT TEST PLAN

PROJECT FIREFLY II 
TABLE OF CONTENAS

WOREWORO

TAELE OF CONTENTS

1.0 OBJECTIV

2.0 SCOPE

3.1) BACXOROUND

4.0 PARTICIPATING ORGANIZATTONS

5.0 TEST REQUTREMENTS

6.0 SPECIAL ACTIUNS

7.0 TEST SCHEDULE

APEENDIX I: TESI PROCEDURE

I BASIC EVALUATION PLAN

II SAEE勧Y PEAX

IV, SEOURITY PLAN

V DISTELHUTION DLAN

VI STATE OF ALASEKA TEST PLAN

ANNEX I EVALUATION OBJECTIVES

I BREING HANDUUT ON RL PORTABLE LIGHTING

II PROCEOURES FUR A-10 EVALUATION

IV HROCEDURS FOR C- $\$ 30$

$\checkmark$ AIRTREW OUESTTONNAIRE

VT INSTALLATION BRIEFING OLAN

VII GROUND SUPPOHT CREN OUESTTENAATE

VIL TERMS, DEFTNTTIONG \& ACRONYMS

¿X STATE OF ALASEA EVALUATION RLAN

$X$ ALLEN AE STTES 
FOREWORD

PROJECT FIREFLY is a joint Department of Energy (DOE) and Department of Defense (DOD) program establiahad by the DOD/DoE Rl. Technical working Group (RL-TwG) to develop unique airfield night lighting devices powered by radioluminascent (RL) phosphors. This Arctic Test Plan (ATP) has been prepared by the RL-TW(: to respond to the AAC mission requirement for a self-sustaining artida lighting system suitable for Arctio deployment. The RLThe shall test several RL aitield lighting applications during

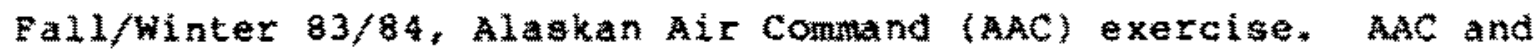
other users shall evaluate the operational success during an Evaluation Review Board (ERB) following the exercise. Air Force Engineering and Services Center's (HO AFESC) Engineering and Services Laboratory (ESL) has overall responsibility for the test. The success of this Arctic Developmental Test will dapend largely upon the cooperative efforts of the DoE, the National Guard Bureau (NGB), and state of Alaska operating under the auspices the RL-TWG. 


\section{AIR FURCE ENGINEERING AND SERVICES CENTER \\ Tyndall Air Force Base, Florida 32403}

IMPRUVED TRITIUM RADIOLUMINESCENT (RL)

AIRFIELD LIGHTING

DEVELOPMENT TEST PLAN

PROJECT FIREFLY II

ACRTIC TEST PLAN (ATP)

This test plan has been reviewed and approved by:

THOMAS C. HARDY

Project officer/Technical

Director

JOHN F. GOIN, Lt Col, USAF Chief, Engineering Research Division

ROBERT HOYER, COL, USAY

Director, Engineering Services Laboratory

WILLIAM C, REMINI

DCE Program Manager P\&D and

By-Product Utilization Division

JOSEPH CALLAHAN, COl, USAF

Commander, HQ AFESC.
RALPH L, HODGE, Col, USAF DCS/Engi neering Services

CARL A. MANSPERGER, Col, USAF DCS/LOgistics, HO AAC

WILLIAM H. BRANDT, COI, USAF Inspector General, HO AAC

WILLIAM R. POVILUS, Col, USAF DCS/Operations, HQ AAC

RICHARD 0 . BENNETT, COL, USAF Vice Commander, HO AAC 


\author{
"PROJECT FIREELLY II" \\ ARCTIC TEST PLAN
}

1.0 OBJECTIVE: The objective of this developmental test and evaluation (DT\&E) is to evaluate the operational suitability and effectiveness of the improved tritium runway lighting to support military aircraft operations, and also to allow further design refinement prior to a full scale initial operational test and evaluation (OT\&E).

2.0 SCOPE: This work unit (JON 2673-0034) shall be conducted over a period of approximately six months. (Reference:

SCHEDULE, Section 7.0.). The contractor, Oak Ridge National Laboratory (ORNL), shall deploy a second generation set of tritium airfield lights and fixtures to be deployed consecutively at two locations in Alaska, test flown, and evaluated by aircrews of various aircratt. Ground support crews will also evaluate the ease of deployment, installation, reconfiguration, maintenance, and redeployment of the lights. Lights will be provided by Department of Energy, Uak Ridge National Laboratory (ORNL), and will include a combination of runway and taxiway lights, visual approach slope indicator (VASI), and helipad lighting systems. Several organizations shall provide radiological protection and test consultation services at the ATs during executing of the ATP. The Engineering and Services Laboratory (ESL) shall orchestrate the ATP to insure all test objectives are tested and evaluated. HO AAC shall provide the ATS, make its resources 
avaliable to the test team, coordinate the ATy with the rall Winter $83 / 84$ exercise participants, and direct the Evaluation Review Board (ERB) to assess the results of the Arotic Test. ORNL and ESL shall observe the ERB to document the test results in interim and thal technical reports.

3.0 BACKGROUND: A joint DOD/DOE study group was tormed to develop applications for Defense nuclear waste radioisotopes as "aternate energy" lighting systems. This group, now known as DOD/DOE KL Technical working Group (TWG), has identitied and demonstrated many military applications.

The military, and specitically the Air force, is investigating alternate airfield lighting systems which provide improved portability, maintainability, and operational support. Radioluminescent. (RL) lighting uses radiation Erom radioisotopes in combination with phosphors to produce visible and infrared (IK) light. Oak Ridge National Laboratories (ORNL), under contrat to the Department of Energy (DOE), applied earlier technology and developed RL lignting utilizing tritium as the energizing isotope, and inithaly demonstrated this lighting in 1980. The tritium Iighting is completely portable and does not require any wiring, external power, or fuel. These characteristics offer potential for worldwide application, but the need is especially evident for use at tactical operating locations (TOLs) during the long and dark arctic inters.

Subsequently, joint DOE/ESL sponsored research at ORNL produced a report entitled. Tritium-Powered Runway Distance and 
Taxiway Markers, ESL-TR-41-45, Aug 61 . ORNL performed the initial evaluation tests on these RL signs, which included the evaluation of illumination intensity, discoloration, temperature, thermal shock, pressure, impact, vibration, immersion, rough handling, blowing sand, and service life tests.

The program became known as PROJECT FIREFLY when tests of an improved RL fixture were conducted by ORNL at Bogue MCALF, NC on 14-18 sep 81. These test evaluated the product of joint DOE/ESL sponsored RL developments (ESL-TR-80-55, and ESL-TR-82-12), and showed that the new fixture was at least twice (2288) as bright as the original prototypes. During 9-12 Aug 82 tests at Rogue MCALF, URNL conducted a developmental test and evaluation (DT\&E) of a new tritium light fixture geometry redesigned to provide a significantly greater area of light emission.

In 1982, Air Force Engineering and Services Center (AFESC), Alaskan Air Command (AAC), and the state of Alaska Department of Transportation and Public Facilities (AKDOTPF) incorporated a tritium light test into the joint service exercise, BRIM FROsT 83. The results of this test showed the lights had potential for runway application, but design improvements were required primarily to improve the acquisition range by airborne pilots.

In July 1983, a newly designed tritium light was shown at a conference hosted jointly by AAC and AKDOTPF. Planning was initiated to operationally test the new lights during 1983-84.

A final report concerning this military test shall be approved by HQ AFESC, HQ AAC and coordinate with HQ MAC. AFESC 
will published results for distribution to all participating agencies.

The program priority and direction to develop an aiffield lighting system that would fulfill air force needs for air base survivability and mobility are established in the collowing docum ments:

1. Program Management Directive (PMD) Draft for Portable Astield Lighting Systems (Program Elenents: $27596,28031,28032-T_{1}, 41115,41896-$ MAC and 626011. 2. HO USAF Statement of Nead (SON) DraEt soN-1-82 for Improved Energy Sele-Sufficient Airtield Lighting (Format B).

ORN Installed (RL) runway and threshold alrfield lighting system for the pre-Artic test at Mackall Amy Airfield, N.C. on 2-3 Nov 83. The unofficial test results indicated the Alrift Center (ALCENT) C-130 aircrews were able to acquire the RL lignts within 4-6 natical miles (NW) rom the touchaow zone as required by MAC. ALCENT provided more than $20 \mathrm{c}-130$ low approaches over Mackall AA. Eeedback from the ACCENT"s test director indicated the aircrew members' ability to acquire the Rt lights improved with each approach. Some C-I30 aircrew members were acquiring the lights 6.2 Nw from the touchdown zone* 4.0 PARTICIAATING OAGANIZATIUNS: Key project Personnel 4.1 At Eorce Engineering and Services center: HQ AFESC RDCS: USAF Test Manager, Mr Thomas Hardy, (904) 283-6275, AUTuVon: $970-6275$, Associate Test Manager, Mr Wade Grimm, (904) 283-6284, AUTOVON: 970-6294. 


\subsection{Alaskan Air Command: HO AAC}

Duos: Staff Executive Officer, Test Director, Maj Lee Hult, AUTOVON: 317-552-5346.

DE: DCs/Engineering \& Services, Col Hodge, AUTOVON: $317-552-5222$.

DEM: Director of Operations and Maintenance, Maj Syta, AUTOVON: $\quad 317-552-4142$.

SGB: Command Bioenvi ronmental Engineer (BEE), Lt col Richard Nuss, AUTOVON: 317-552-4282.

616 MAG/DU: Director of Operations, Col Snider, AUTOVON: $317-552-5517$.

4.3 Military Airlift Command: HQ MAC XPOT: MAC Test Coordinator, Maj Bob Oertel, AUTOVUN: $638-3903 / 4$.

USAFALCENT/RA: MAC Test Advisor, Maj Ron Jones, AUTOVON: $486-2449$.

4.4 Headquarters United States Air f'orce: HO USAF LEEVX: USAF Project Coordinator, Maj Harold W. Olson, (202) 697-4173, AUTOVON; 297-4173.

4.5 Radioluminescent Technical Working Group: RL-TWG DEPARTMENT OF ENERGY HO DOE: Program Manager, Office of Defense Waste and By-Product Management (DP-123)/Chairman, RL-TWG, Mr William C. Remini; or Mr Tom Anderson, (301) 353-4265, FTS: 233-4265. ORNL: Program Manager, Mr Karl Haff (615) 574-70y6 F'Ts 624-7096. Principal Investigator(s), Mr Neil Case; or Mr Andy Tompkins, (615) 574-7105/7095, FTS: 624-7105/7095. 
DuEforu: Contract Manager, Mr Doyle Brown, (615) 576-4376, FTS: $626-4876$

Ho NGi/PO: Chier, Ottice of Policy bialson, Lt Col William Florence, (202) 695-6998, AUTUVON, 225-6998.

North Carolina ARNG: Air Operations Officer, Lt Col Les Everett; (919) 733-2555, AUTUVon: 582-9181. STATE UE ALASKA

Alaska-DOT: Chief, knergY Building RLD (DUT/RF), Mr Lee Leonard, (907) 479-3003/2241/4650.

Alaska-ANG $(176 \mathrm{TAG} / \mathrm{CAG})$; MAC/ANG Lialson OfEicer, MaJ Er\% Hobos, (907) 243-1145 x 200, AUTOVON; 317-626-1200/1444.

batelle-Alaska: Alaskan Operations Manager, Mr Lyle $D$. Perrigo, (907) 274-9811 or;

Battelle-PNL: Senior Research Engineer, Mr George A. Jensen, (509) 375-2602.

4.6 United states Air Force Radiological protection Comittee: USAF-RPC.

Ho AFMSC/SGPa: Radiosotope Comitcee Recorder, Capt Bollinger, AUTOVON: $240-3331$.

5.0 TEST REOUIREMENTS:

5.1 HO AEESC/RDC WII pertorm a developmental test on the second generation of tritum RL-lights.

5.1.1 The triciur threshold lights should be visually acquired at a minimum distance of tour nautical miles by $\mathrm{A}-10 /$ C-l3U pilots flying in total dakness, when the atmospheric visability is seven nautical miles or groater. 
5.1 .2 The tritum lights should allow accurate runay alignment guidance at a minimum of two nautical miles.

5.1 .3 The tritium VASI system should provide glide path information at minimum of two nautical miles.

5.2 The ground support people shall evaluate tritium light fixture assemblies to determine whether or not they present hazard to ground personnel, aircrat or surrounding environment.

5.2 .1 The tritium tixtures should be designed for temporacy instaliation at remote airfields,

5.2 .2 The tritium fixture design should contain a simple built-in security system to help minimize thett of the lights.

5.2.3 The tritium fixtures should be durable, light weight and easy to assemble and disassemble in the arctic and subarctio envi ronment.

5.2 .4 The tritiun lights should be capable of prom viding a continuous and reliable light source under severe arctic temperatures and weather conditions,

5.3 The airtield lighting waiver reguired by $\mathrm{AF}$ B-14, Para 1-9, shall be arranged by HO AAC/DoOs and coordimated with HO AAC/DU, HO USAE/LBEEU/LEEVX/XOORE/RDRO, HO AFESC/RDCS AND EAA/ACT-350. ORNL shall provide working drawings of protocype fixtures as they are required to satisfy the waiver.

5. 4 GRNL shall work with the TWG Test Director to arrange for transport of the test \pm ixtures and test team to an ardic Test site (ATS) in Alaska to be determined by Ho AAC. 


\subsubsection{The fixtures shall be installed to illuninate a}

Lbu tt $\times 5000$ te runway.

5.5 ORNL/PNL shall provide on-site technical support in Alaska furing the deployment to maintain the lighting system and obserye the evaluation.

5.6 An approved tritium light questionnalre shall be distributed by AAC to participating flying organizations EOLlowing a briefing by HO AAC/DOOS.

5.7 The test team evaluation shall be completed in two parts to tollow the approved test plan. OKNL shall perform all data reduction and analyais and fully document the test remults In the lnterim and final technical reports.

5.7.1 Part I - Visual Evaluation: Results of the questionnaire survey will be summarized by an evaluation review board di rected by $\mathrm{HO} \mathrm{AAC} / \mathrm{ADO}$ who will make a witten assessment ot the overali operational accetability ot the tritium lifhts. 5.7.2 Part II physical Evaluation: ubservations. photographa, and interviews recorded while the test tean witnesses the evaluation shall be condensed by ORNL and presented in the tinal reports.

5.8 Upon completion of the evaluation, ond shall recover and return the complete titium lighting system to vak kidge, TN. ORNL/RNL shall remain in custody of the lighting system until furtiner testing or aisposal at che discretion of the Dot program Manager.

5.9 Reporting: ORNL shall prepare interin and tinal technical reports which shall include all data calculations and 
analyses required in this technical effort. In addition, OKNL shal include detailed descriptions, photographs, and drawings of the inal fixture design; forication installation techniques: installation flight training plans; final erection problems; shipment limitations: and detaled project coste. The final technical report shall cover complete system performance limited to the actual field observations during this test to include disposal method and cost. Conclusions and recommendations concerning further wse, turther RsD, and projected economic analysis (i.e., cost of lst...10th...100th runway) of fl airfield lighting shall be delineated as an overall assessment of the project

5.10 Responsibilities: The participating organizations are asigned the following responsibilities:

5.10 .1 Engineering and Services Laborator: (ESL) Prepare necessary documents for internal coordination. 5.10 .1 .1 Assign USAF Test Manager who will orchestrate the test activities and prepare all special actions tiox TWG coordination:

$$
\begin{aligned}
& 5.10 .1 .1 .1 \text { Test plan } \\
& 5.10 .1 .1 .2 \text { Liaison with USAF kadio- }
\end{aligned}
$$

Logical protection Comattee

$$
5.10 .1 .1 .3 \text { Coordinate all test }
$$

activities with wO AAC.

$$
\text { 5.10.1.2 Coordinate transportation of USAF }
$$

personnel with Test Director. 
5.10 .1 .3 Frovide input to ORNL concerning pre-

test evaluation.

$5.10,1.4$ Review prelininary development

evaluation dratt report.

5.10.1.5 publish and distribute final system development report.

5.10.1.6 Prepare, distribute, collect and analyze aircrew and ground support personnel questionnaire.

5.10 .1 .7 Act as Dod test managex. Will

coordinate with DoE on TWG matters.

5.10 .2 Alaskan Air Command: (HO AAC)

5.10 .2 .1 Assign Test Director who will

orchestrate test flights and required test support.

5.10 .2 .2 Provide Arctic Test site (Ars).

5.10 .2 .3 toordinate ATP with winter exereise

authorities to determine availabiliky of ATS and time of ArP execution.

5.10.2.4 Provide photographic documentation.

5.10 .2 .5 Provide ground support for light

deployment.

$$
\text { 5.10.2.6 coordinate and direct pilot }
$$

evaluation board.

5.10 .2 .7 Make at least one venicle available

Eor transportation at ATS.

5.10.2.8 Provide schedule of day-tomay

operation involving tield test (coordinate with test director). 


\subsection{0 .2 .9 Provide adequate security for}

deployed lights.

$$
\text { 5.10.2.10 Provide weather information and }
$$

documentation.

$$
5.10 .2 .11 \text { Coordinate the use of non-AAC test }
$$

airfields and facilities.

$$
\text { 5.10.2.12 Arrange for distribution of pilot }
$$

questionnaires and provide preliminary results.

5.10.2.13 Arrange participation by difterent

type aircraft.

5.10 .2 .14 Obtain/provide authorization for test team personnel to have access to tritium lighting storage, deployment and test locations.

$$
\text { 5.10.2.15 obtain/provide authorization for }
$$

test team personnel for emergency medical aid; issue of arctic clothing and vehicles for transportation.

\subsubsection{AAC Test Director:}

5.10 .2 .16 .1 Act as Point of Contact

with DUE Test Advisor in concert with DOD Test Manager, DOE Program Managers and TWG Test Director.

$$
5.10 .2 .16 .2 \text { Assist in preparation }
$$

and review of test plan.

$$
5.10 .2 .16 .3 \text { Coordinate ANG/ARNG }
$$

activities throughout test.

$$
5.10 .2 .16 .4 \text { Coordinate and provide }
$$
Arctic clothing for team members not stationed in Alaska. 
5.10.2.16.5 pereorm as communications trequency manager for test team by coordinating communications call signs and FM frequendies for communications between team members and aircrat as required.

$$
5.10 .2 .16 .6 \text { AAC/DO revresentative }
$$

wil function as AAC test director; direct tlying test prograra; interface wth participating aircrews; and assist in evaluating tritium lights based on objectives and criteria in this plan.

$$
5.10 .2 .16 .7 \text { AAC/DE representative }
$$

will ensure layout and setup is accomplished per Air Operations officer's recommendation; ensure modiflcation and maintenance of tritium lights as required and assist in evaluation of the lights per this plan use of Allen Army Airield, AR.

$$
5.10 .2 .16 .8 \text { obtain witten approwal. }
$$

to AR $385-11$, paragraph $2-3$.

$$
5.10 .2 .17343 \text { COMPW: }
$$

5.10 .2 .17 .1 Appoint an $\mathrm{A}-10$

qualified project of ficer to coordinate A-lu tight operations. brief/debrief pilots, and coordinate with local agencies participating in the evaluation.

$$
\text { 5.10.2.17.2 Ensure the base kou }
$$

monitors and approves axrangements ror delivery, transportation, storage, and deployment/redevloyment of the tritium lights until transferred to the 21 TFw for deployment to Donnelly Lz.

$$
5.10 .2 .17 .3 \text { provide } \mathrm{A}-10 \text { and } 0-2
$$

aircraft to participate in evaluation. 
5.10 .2 .17 .4 provide at least four

personnel for receipt and transwort of tritium lights upon arrival in Alaska* Since battelle/pacific National Laboratory is custodian of the RL light fixtures, their representative will be present to count and make suitable checks on the receigt of these Eixtures.

5.10.2.17.5 Provide an enclosed bed cargo truck and cargo van for transporting the lights. The vehicles should be latge enough to hold containers taking up about two $463 \mathrm{~L}$ pallets, be weatherproof, and be capable of being secured.

$$
\$ .10 .2 .17 .6 \text { Provide a secute }
$$

location for temporary storage of the tritium lighting and shipping packages, as necessary.

$$
5.10 .2 \ldots 17.7 \text { provide tour personnel }
$$

for transportation and installation of lights at Allen AAF. including assistance in varying test configurations, pertorning fixture maintenance and removing the lights and fixtures. These should be the same cour personnel in 5.10 .17 .4 .

$$
5.10 .2 .17 .8 \text { provide vehicle and }
$$

runway condition reading RCR measurement equipment and operator to conduct RCS/RCR measurement IAW $T * 0,33-1-23$, if required by the AAC test di rector.

$$
5.10 .2 .17 .9 \text { provide ground to air }
$$

communications (UkF/VHF). 
5.10.2.17.10 Provide personnel and equipment, as necessary, to support A-10 turnarounds at the designated test airfield, if required.

\subsection{0 .2 .1821 TFW:}

5.10.2.18.1 Provide a contingency storage location for the tritium lights at Elmendorf AFB.

5.10 .2 .18 .2 Appoint a rated project officer to coordinate operational aircraft support tor the test at Allen AAF.

\subsection{Provide C-12 aircratt}

support for evaluation of the lighting system.

$$
5.10 .2 .18 .4 \text { Provide four personnel }
$$

to deploy the lighting package from Eielson AFB to Donnelly L2: and install, maintain and remove the lights and fixtures.

$$
\text { 5.10.2.18.5 Deploy, install, }
$$

maintain and redeploy an electroluminescent (EL) or conventional incandescent lighting. set from Eielson or Elmendorf to Donnelly Lz which will provide backup lighting for c-130 support.

\subsubsection{Military Airlift Command: (HO MAC)}

5.10.3.1 Provide MAC aircrews and aircraft to evaluate the RL lighting at the ATS.

5.10.3.2 Extend a MAC Airfield Lighting Waiver to the RL lighting system for the period of the ATs deployment. 5.10.3.3 Assist in preparing, distributing. collecting and analyzing aircrew and ground support personnel questionnaires. 
5.10 .3 .4 Ensure aircrews and ground support personnel are brieted and debriefed.

5.10 .3 .5 provide a Radiological Protection Ofricer (RPO) to approve and monitor handling, storage, transportation and use of the tritium lights wile involved in AAC testing. (Custodial responsibility will be maintained by the Dot or its designated contractor representative.)

\subsection{0 .4 Heaqguarters, United States Air Force: (Ho}

USA

$$
5.10 .4 .1 \text { Provide timely Air state coordination }
$$

of the ATP.

$$
5.10 .4 .2 \text { provide a USAF project coordinator }
$$

Action ofticer as a focal point for executive coordination and management briefings.

\section{$\$ .10 .5$ Headquarters Department of Energy: (HO DuE)}

5.10 .5 .1 serve as Chairman, RL-TwG.

5.10 .5 .2 Provide program management dicetion

for all DoE test activities.

5.10 .5 .3 Coordinate test plans with responsible DOD personnel.

5.10.5.4 Coordinate test preparation and boe requirements with ORNL.

5.10.5.5 krovide executive management briefings as required.

$$
\begin{aligned}
& 5.10 .6 \text { Qak Ridge Ouerations Office: (DUE/ORO) } \\
& \text { 5.10.6.1 Coordinate test plan with DOD. }
\end{aligned}
$$


5.10 .6 .2 Coordinate HO Dos requirements for contract documentation botween ORO and ORNL.

5.10 .6 .3 Provide test and assistance personnel

during test*

5.10 .6 .4 Approve and asaist in RL light system and equiphent security planning and execution.

5.10 .6 .5 Provide reimbursement authocization

letter to non-Dos support personnel for travel, and subsistence.

5.10 .7 Oak Ridge National Laboratory: (ORNL)

5.10 .7 .1 Prepare prototype fixure.

5.10 .7 .2 fabricate adequate quantity of RL

light fixtures for a 5000 to runay.

5.10 .7 .3 Prowide planing for pre-test evaluation (Euld scale).

5.10 .7 .4 prepare shipping documents and

accountability docunents.

5.10 .7 .5 Artange transportation for pre-test

evaluation.

5.10 .7 .6 Deploy lights for pre-test evalua-

tion.

5.10.7.7 Make required modifications.

5.10 .7 .8 prepare check 11 ts and inventory

Iists.

5.10 .7 .9 eackage lights and equipment for

transport to Alaska.

5.10 .7 .10 obtain final concurrences for

shipment from oRO/DOE. 


$$
\text { 5.10.7.11 Provide technical guidance in }
$$

assembly of lights at destination.

5.10.7.12 Provide briefing to HQ AAC Radiological protection officer (RPO) and ground support installation team on light handing and safety assessment.

$$
\text { 5.10.7.13 Train and brief ground support }
$$

installation test personnel on test objectives.

$$
\text { b.10.7.14 Supervise and assist packaging of }
$$

lights for return to ORNL.

$$
\text { 5.10.7.15 Make final inventory and transfer }
$$

documents.

$$
\text { 5.10.7.16 Prepare dratt test evaluation docu- }
$$

ment and distribute for comments.

$$
5.10 .7 .17 \text { Prepare draft technical report and }
$$

distribute for comments.

$$
5.10 .7 .18 \text { Prepare final technical report for }
$$

distribution.

$$
\text { 5.10.7.19 Initiate fund reimbursement letter }
$$

for travel of non-ORNL personnel as required.

5.10.7.20 Assist in preparation of test plan.

5.10 .8 Pacific Northwest Laboratory (PNL) will perform cold climate engineering and human factors work reguired for field testing. Provide required support to and or in lieu of ORNL responsibilities (above).

\subsubsection{6th Tactical Airlift Group:}

5.10.9.1 Provide transportation support for transfer of lights from ORNL to and from Alaska. 
5.20.9.2 Effect physical transfer to AAC.

5.10 .9 .3 Notity HO AAC/DOUSS of exact delivery

time as early as possible.

5.10 .9 .4 provide a $6-130$ aiforaft for evalua-

tion purposes at Allen AAF

\subsection{0 .10 National Guard:}

5.10.10.1 North Carolina Amy Air National

Guard (NC-ARNG) vill provide training in Alaska same as TwG Test

Director and will provide logistical support for the ATs. Will

coordinate test procedures with AK-ARNG, AK-ANG.

$$
5.10 .10 .1 .1 \text { Proyide airewey }
$$

briefings on best method to acquiation trithum RL-lights during test.

$$
5.10 .10 .2 \text { Alaska Army National Guard }
$$

(AR-ARNG)

5.10.10.2.1 Provide helicopter

transportation for personnel and equipment within local vicinity ot ATS.

5.10 .12 .2 .2 Frovide helleopter

support for test.

$$
\text { 5.10.11 Scate of Alaska: (AR-DUT) (See Appendix F) }
$$

\$.10.11.1 Fabricate and install light base

units at test site.

5.10 .11 .2 provide liaison between state of Alaska and the RL-TWG. 
5.1U.11.3 AKDOTEF, Battelle AR, and other test team nembers, as applicable, will advise test director on contiguration, modification and evaluation of tritium lights in conjunction with FAA evaluation state of ATS.

5.10.11.4 Erovide a secure storage area upon transfer of equipment in Alaska prior to AK-DOT deployment.

$$
5.10 .12 \text { United States Air Force Radiological }
$$

Protection Committee: (USAF-RPC)

5.10 .12 .1 ORNL/PNL 111 perforn Radiological Protection function as outline in Appendix $\mathrm{C}$.

$$
\text { 5.10.12.2 Advise } 10 \text { AAC/sGB of their reapon }
$$

sibilities.

5.11 Satety: See Appendix C.

$$
5.12 \text { Security: See Appendix D. }
$$

6.0 SPECIAL ACTIONS:

6.1 Security classification: It is anticipated that the securtty classification for this project w11 remain unclassitied.

b.2 Release of Information: Ald infomation concerning developments under this contract shall be reported to other agencies through Ho AFEC/RD. Until public release of the 1 thal technical report by the USAF, there shall se no briefings, fresentations, publications, or information relative to this technical eftort transmitted by ORNL without prior approval of $\mathrm{HO}$ AFESC/RO and the DOE Program Manager. 
6.3 Ufticial photography: ORHL shall cooperate with the official Air Force photoyraphic support arranged by $\mathrm{HO}$ AAC/DOOS for the Air force Project Officer and the DoE Prouram Manager. 6.4 Radiological protection officer (RPO): ORNL/PNL will assist the RPO during the entire contract period. coordination tor thanding the RL markers will also be accomplished by ORNL wh AFMSC/\$GP2, Brooks AFE, TX 7\&235.

7.0 SChEouLE: The Eallowing schedule applies:

7.1 TRITIUM LIGHTING TEST SCHEDULE

Phase

\begin{abstract}
preliminary Test
\end{abstract}

C-130 Test (Annex ty)

Weather backup

End of AAC Test

Deployment
Deployment

Date

18 Hov 83

19 Nov 83

$19-22$ NOY 83

83

Contiguration and yisual acquisition

23 NoY 83 $27-29$ NOV 83

28 Nov -11 Dec 83

\section{1 ber or Eariter}

11-15 Dec

15 Dec 83 range evaluations by: AAC, ADOTPE, PEA, AK ANG, and AK ARNG Light fixtures/bases packed up and transported to secure storage at Elelson $A F B$.

Lighting package picked up from Eielson AFb and transported by 21 TEW personnel to Donneliy $\mathrm{Lz}$ and installed

Lignting package delivered by 176 rat $C-130$ to Allon AAE

Light Ixtures/bases secured/lights installed

Uperational evaluation during this period

Lighting package returr to Eielson by 21. Thw las directed by AAC test director

Weather backup for Allen and/or A-los as needeo

Transfer to state of Alaska for AKDOTPE testing 
$\begin{array}{lll}\text { Phase } & \text { Date } & \text { Event } \\ \text { End ot } & \text { Mar } 84 & \text { Lighting package returned to Lower } \\ \text { Alaska Test } & & 48 \text { by } 176 \text { rAG }-130\end{array}$

7.2 Scheduled events.

7.2.1 18 Nov 83 - The tritiun lighting package will be delivered to Allen AAF, AK, by 176 IAG via C-130. The package w11 be accompanied by and/or met by member(s) of the test team and custodial representative (PNL). $343 \mathrm{~d}$ personnel will receipt and transport the lighting to the sectue storage location. The $343 \mathrm{~d}$ KPO and Battelle PNL representative wil inspect the 11 ghts and packaging. If weather conditions do not permit the $6-130$ landing at Allen AAF, Eielson APB will be the alternate delivery location. In the event of a divert to Eielson AFB, 3430 personnel will be notitied as soon as possible so all support can be repositioned.

7.2 .219 Noy 83 - The fixtures 11 be ingtalled on the artield jer instructions of Test Director (Annex VI). The runway will be determined by the AAC test director.

7.2.3 19-23 Nov 3 - Preliminary Test Period. This period wll be used to evaluate installation methods, alternate lighting configurations, and visul aquition range, contingent on other airtida operations, the tritum lighting test wil begin approximately $1600 \mathrm{~L}$ and end at $2000 \mathrm{~L}$ daily.

$$
7.2 .3 .1 \text { During each test period, aikctatt will }
$$

tly multiple low approaches, with full stops and takeoffs, using the tritum lighting. The pilots wil receive a briefing lannex 
III. IV) prior to the irst fight, complete the questionnaire (Annex $V$ ), and be debeiefed by test personnel as appropiate.

7.2 .3 .2 After each cest sequence the lighting configuration may be altered in an atcempto improve pertomance. Each change will be fully coordinated with the pilot(s) Elying during that period. Their questionnaire coments must be keyed to the specitic test.

$7.2 * 3.3$ At the completion of each test period, the test team may remove che lights and place them in secure storage. The lights may remain installod it no participant. including the Allen AAF managez; has any objections.

7.2.4. A-10 Operational tvaluation. Not less than four 343 Compw A-10 aircraft will participate in a the cest. If weather conditions and runway condition reading (RCR) permit, the site wil be Allen AAF. If Allen AAE is unacceptable, another test will be completed at a suitable A-lu location, with Eielson Aflu as a last selection. Each A-10 will make at least one low approach to the lighting system prior to a tull stop. After the full scop the pilot will be debrieted. after takeoff, the pilot may make additional low approaches, fuel permiting prior to returning to Eielson AFt. Qach pilot wil complete the airorew questionarize.

\section{2 .5 27-29 Nov 8 - c-130 uperational Test Deploy-} ment, 21 TFW personnel will transport and instali the tritium Iighting at Donnelly Lz. Test team nembers will be present to provlde supervision and assistance. Lighting will be installed IAW MACK $55-130$. 
7.2 .620 Nov - 11 Dec $83-4-130$ Uperational wast. C-130 aircraft supporting the 172 Infantry brigade Field Training Exercise will land, using the tritium lighting. A conventional backup lighting system will be available, and turned on if the 1) 1 10t catuests.

7.2 .711 Dec 93 - Tritium and conventional lighting removed from Donnelly Lz by 21 TFW and test team personnel and returned to Eielson AFB and cemporarily stored.

7.2 .815 Dec 83 - Tritium lighting package transterred to AkDOTE for civilian testing. 


\section{APPEMDIX I}

PROCEDURES FOR

PRELIMINARY TESTING OF

\section{RL RUWWAY LIGHTING}

1. Each organizaiton or agenoy participating in the tritium runway lighting test will appoint a project officer or point of contact for scheduling brieting and coordination.

2. Organizations and aircraft which will be directed or invited to participate are as follows:

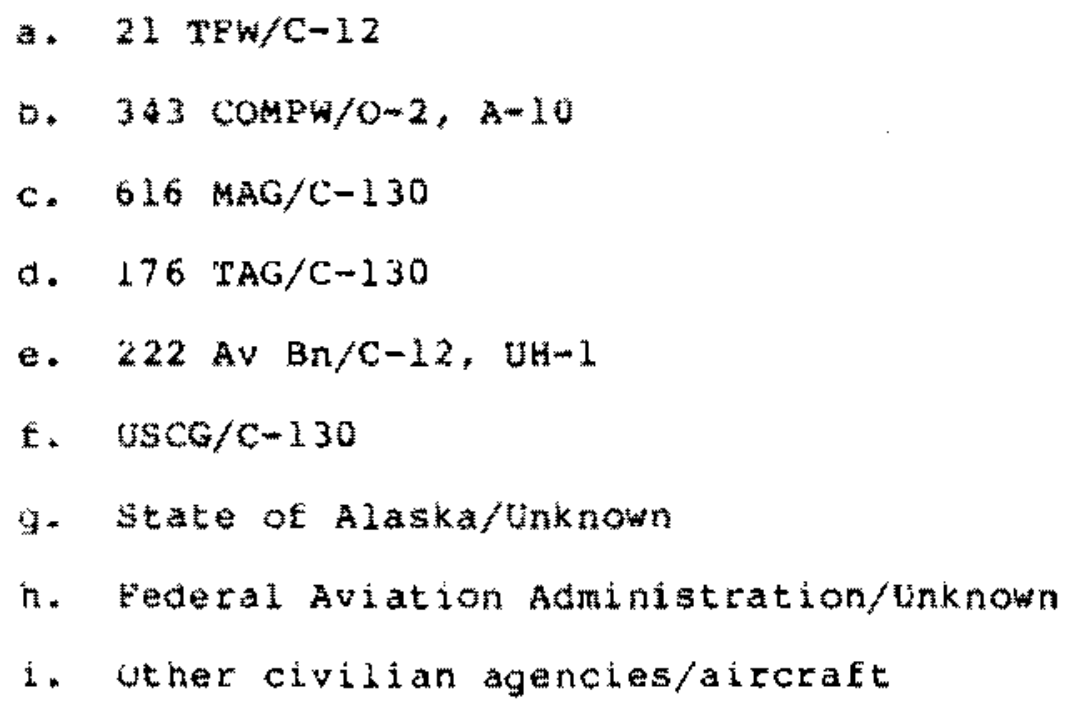


6. Pilots will thoroughly familiarize themselves with the terrain surrounding Allen AAF and the layout of the airfield and runway .

7. The primary runway for testing the lighting at Allen AAF is anticipated to be Runway 18. Runway 18 is $7499^{\prime}$ long and $150^{\prime}$ wide. Depending upon tritium lights available, only 5,000 feet will be lighted. Runways 36, 06, 24, 09 and 27 may be used if conditions warrant.

8. Prior to their flights, pilots will receive a thorough briefing on the runway in use, lighting configuration, radio frequencies, and other pertinent information. y. The pilot will contact the test team on the specified radio frequency as soon as possible. At that time, he will receive an additional briefing on current status of lights, weather conditions, and runway condition reading ( $R C R$ ) or latest reported braking action.

10. Pilots will align the aircraft on the extended runway centerline, at least five miles from the threshold. This may be accomplished visually or by use of TACAN DME information. 11. Pilots will, as accurately as possible, document the maximum distance at which the lights are acquired and the distance the lights become usable for runway alignment and/or glide path information. TACAN DME will be noted if used for measurement. 12. If weather conditions permit, the pilot will execute a low approach and return to the final approach for a second view of 
the test lighting. Pilots may subsequently land or execute additional low approaches. At least one tull stop landing is requested. Pilots ill provide comments to the test team while on the ground.

13. Civilian pilots way make fow approaches. Full stop landings are authorized if Us Army civilian use requitements are met.

14. Pilots will complete the handout questionnaire and subme to the unit project officer or mail to HQ AAC/DOUSs, Elmendorf AFB, AK 99506.

15. Enginears andfor ground support crews will also complete questionnaires and submit to the project oficer or mail to ho AAC/DEM, Elmendorf AFB, AR 99506.

16. The AAC test director will establish operating procedures/ methods depending on site environnental conditions during the test. 


\section{APUENOIX II \\ BASIC EVALUÄTTON PLAN}

Introduction

subjective analysis of ground observations and aircrew questionnares shall be the primary methods of data collection. The approved tritium light questionnalye (ANNEX VI) shall be briefed and distributed to participating fying organizations by HO AAC/DOOSS. Members of the team shall interview Prime BEEF and other ATS support personnel to determine the success of ground operations. At the conclusion of the exercise, Ho AAC/ADO shall direct an Evaluation keview Board (ERB) to make a written assessment of the overall operational acceptability of the fir ighting system under Arctic operations. ESL and ORNL/PNL shall observe the ERB eritique to document the results and recomendations in the inal technical reports.

\section{Method}

The test team evaluation shall be completed in two parts to Follow the ATP. URNL shall perform all data reduction and analysis to document test results in the interim and final technical reports.

Bart 1 - Visual Evaluation: Guetionaires shali be distributed to aircrew and ground observers as they inmprocess the exexcise and during daily preflight brietings. The observers will receive an explanation of the purpose of the test. The 
पuestionnaires can be returned by self-addcessed mail to hO AACf Dooss. Those received by the end of the exercise shall be reviewed by ERB.

part II - Physical Evaluation: ORNL/PNL shall collect, analyze, and condense the test ceams observations, photographs, and whess interviews at the ATS. Preliminary findings shal be oriefed at the ERB and presented in the final reports. Evaluation Oojectives (See Annex VII)

\section{Data Collection}

The evaluation objectives shall be evaluated from the Following sources collected by AAC, and the RL-TWG test team:

1. Aircrew Questionnaires

2. Ground and Airborne observations

3. Indi idual Interviews

4. Mission Debriefings

5. Exercise Critutue

5. Evaluation board

7. Photographic Aids

\section{Analysis}

The final reports shall contain the Rt airfeld lighting's actual system werocrance under Arctic conditions as determined by expert observers (i.e*, Ekat, and other data collackion technigues. A discussion shall explain the final fixture designs, tabrication techniques, expedient instailation methods, project costs, shiqment limitations, and finad erection problems. 


\section{Conclusions/Recommendations}

Proposed tuture applications, futwer lid, and project economic and operational benetits shall be delineated as an overall assessment of the Arctic Development Test. Al conclusions and recommendations shall be substantiated by this analysis and approved by the PROJECI FIRERLY test connt tee before publication,

\section{Documentation}

ORN shall prepare a draft technical report. The final technical report shall be written in accordance with DID $\$-3591 A$. bubmit two copies of draft tinal report within 30 days after completion of sow, section 5.2. Submit reproducible original within 60 days after recelpt of sponsor"s comments on the approval of drafts. Approying authority will be AFESC/RDCs. Reproducible priginal will be a "camera ready" copy reference MLL-STD-847x. Feport shali be published as a joint AFEsc/DoE tachnical reyort. 


\section{APPENOIX III}

\section{SALETY PLAN}

1. Purpose. The purpose of the saxety pian is to anticipate both general and radiological accidents to reduce, control, and eliminate hazardous conditions. Betore ground installation and air operations can begin at the ATS, official approval must be granted Erom the Test Director and the ATS Aifield Manager. The following safety documents are applicable to this test:
Atre $127-4$
AER $800-16$
AER $127-12$
AEOSH STD $127-66$
AER $160-132$
T. $0.00-110-A-12$
A 1 R $161-B$
T. $0.00-110-N-2$
A $161-16$
T. $00-110-\mathrm{N}-3$
AER $161-26$
T. O. $00-1+0-N-5$

2. Gyerall Safecy Responsibility the Test Manager is responsible tor enforcing the overall safety program for the test. The Alaskan Air Command Chiet of Safety (HO AAC/TG) of his designated representative is the safety officer during all air operations. The Test Manger is the safety officer for all other ATP everta at the ATs. The Test Manager will maincain close cooratiation with AAc/lG on all satety natcers.

3. Satgey Areas. The safety requirements of the ATP have been divided into two separate areas to establish the suecific requirements for different operationel areas:
a. General satety.
b. Radiological Safety. 
4. General Safety. The responsibility for general site safety resides with AFESC. The authority to execute specific safety directives is delegated to the Test Manager. The Director of Information ( $\mathrm{HQ} \mathrm{AAC} / \mathrm{PA}$ ) is responsible for public notification of the test.

a. Safety Briefing. The Test Manager will brief all RL-TWG personnel on the safety hazards at the ATs.

b. Visitors. Visitors shall not be allowed at the ATS without approval of the Test Manager or the ATS Airfield Manager. Visitors shall be instructed on applicable area safety regulations.

c. Individual Safety Responsibilities. Careful attention to the hazards at the ATS must be stressed at each level of supervision. The purpose of the safety rules is to outline the most important precautions to be taken with the ATs. These rules do not cover all the possibilities, but as new problems arise, new safety measures will be established to cope with the circumstances. In the interim, common sense must be applied to insure that safety prevails. This entire safety plan must be closely followed by all personnel and enforced by all supervisors. These procedures shall be accepted as minimum standards until the Test Manager, with the concurrence of $H Q$ AAC/IG/SGP authorizes deviation.

d. Vehicles. Speeds shall not exceed $30 \mathrm{mph}$ when driving on unpaved roads. Seat belts will be used at all times while 
vehicles are in notion. Speed within the immediate are of the ATs shall not exceed 10 mph. when vehicle is yarked, the hand brake will be set and the transmisgion placed in reverse ox park Eor aukomatic transmisations.

e. Hypothermia. Extremely cold weather is expected during the rest period. This has the potential tok hypothermia, frost bite and accidents caused by umpared physical ability. Arctic clothing will be issued. Arctic orlentation training will be required for each test team member as they arrive in Alaska. procedures set by the military for emergency supplies required during air travel and field pperations will be imposed on nonmilitary personnel involved in the test.

\section{f. Accident Reporting (Emergency) :}

(1) Scope. This standard procedure is intended to serve as a guide to expedite medical care as a result ot an accident. Ali "post emergency" reporting and accident investigation will be performed by current Air force Regulations and is not within the scope of this procedure.

(2) Responsibility. It is the responsibility of every person involved in this program to be completely familiat with the emergency reporting procedures established by this plan and to immediately implement these procedures after an accident. It is the responsibility of the Test birector to familiarize all supervisors with this procedure, and in turn, the supervisors will explain these procedures to their subordinates. 
(3) Energency Reporting Procedures. After an accident at the Als the following procedure will be tollowed:

(a) The senior supervisor at the scene of an accident will direct appropriate first ald* caution will prevent aggravation of an accident-related injury.

(b) The ATs Dispensary will be immediately notiEled of the nature of the accident, including apparent condition of the injured person, and the location of the accident. The Test Manager or the senior supervisor at the scene shall determine whether to attempt tansfer of the injured to a hospital, or to recuest emergency ambulance support.

(c) The Test Manager or the senior supervisox shall determine the seriousness of the accident. If it is deterwined that the accident is not serious enough to require emergency hospltalization, disregard para $4 f(3)(b)$ and administer first add at the sice. If Eurthex medical attention apears necessary, the injured person will be taken to a doctor by nomal transportation.

y. Eirst Ald. An adeuvate supply of first aid items will be naintained at the ATS. These items will be properly stored and periodically inspected to insure adequacy for an emergency. 5. Radiological safecy. ORNL will perform the responsibilities of the kPO. The Alaskan Air Command BEE (HO AAC/SGP) will have the complete authority for the enforcement of all NRC requicements and procedures while on usa real property at the ATS. The 
satety procedures for handing, transporting, storing, and installing the RL fixtures at the ATS are specified below:

a. Hazard. These tritium-filled tubes do not emit any beta radiation outside their sealed glass containers. But in the event of tube breakage, Type-2R containers wild be on-hand to package the broken tube for sate transport to orkL for disposal. Pexsornel exposure calculations have been made for a maximum creaible coident involving $1000 \mathrm{ci}$ H-3 tone shipuing container of wands): A single light fixture breakage would result in an exposure equal to 10 of the value shown in the 1000 ci release calculation. (see attached ORNL calculation of doee in runway lighting accident.)

b. Responsibility. ORNL representative will be acting as Radiological protection otficer (RPO) to advise and act in radiation incidents. The HQ AAC RPU will be in charge of radiation related problems and ill aovise and act in an overall position of authority should a radiation incident accur during the exercise.

c. Training. The RL-TWG test team ill briet individuals who wil install and dismantle lights prior to any assignment, The installation briafing (Annex III) will cover the following areas:

(1) Safe handising.

(2) Proper installation.

(3) breakage hazards.

(4) Physical security. 


\begin{abstract}
APPENDIX IV
SECURITY PLAN

1. Transportation. Lights will be transported from ORNL to McGhee-Tyson ANGR TN packaged to meet DOT regulations. Transter of lights to an ANG aircraft $(\mathrm{C}-130)$ will be under the guidance of ORNL personnel. A package count will be made to confirm transfer inventory at each transfer point, e.g., loading at oRNL onto transter vehicle, unloading truck and loading aircraft at McGhee-Tyson, unloading aircraft at Fairbanks, Alaska, for transport to the ATs. When loads are divided for transter in more than one vehicle, an inventory record will be maintained.

Light fixtures will be attached to base units previously installed in the field. In the event the test site becomes inactive relative to light use, the lights will be removed from the base unit and placed in a secure area.

Lights will be transported to a secured location following the Arctic testing. Then an inventory of lights will be conducted. Lights will be placed in a secure area during non-test periods.

2. storage. Following the test, lights will be dismantled, placed in "DOT Type A" shipping containers for delivery of lights to ORNL. Arrangements will be made with URNL Traffic Devartment for meeting the aircratt and delivery of the lights to ORNL. A Einal inventory of the lights will be made upon receipt of the lights at ORNL.
\end{abstract}


A notitication list will be mantained by URNE/PNL personnel to provide information to appropriate URNL/PNL and DOE personnel in the event that reportable incident occurs during the test. ho AAC/DOOS/SGP/IG/DE/PA and HO AFESC/RO/PA will be expeditiously notified of any incidents. (See attached notitication list.)

Lights are labeled with a notification statement, radiation symbol, identiffation of radiofotope (teitium) and quantity of isotopes present. These labels ate attached to the base of ach light unit (wand) and a serial number is engraved into the base of each wand. The lights are shown to be the property of the USDOE and in case of an emergency the okNL plant shitt supervisor must de not ified.

3. Notification. The following agencies wil be notified within elght hours of any ceportable incident:

a. Alakan Air Command:

DOOSS: Maj Hult, AUTOVON: $317-552-5346$

SPO: Capt Knall, AuTuvon:

Stib: Maj Cantiohaei, AUTUVON: 317-552-4282

It: Col Brandt, AUTOVon:

DE: Col Hodge, AUTUVUN: $317-552-5222$

PA: Lt col santora, AuTuVon:

b. Aiz Force Engineering and Services Center:

Cc: Col Callahan, Autovon: $970-6101$

RD: Col soyer, AUTUVUN: 9 ta-6309.

PA: Maj Geary, AUTONon: $970-6476$ 
*. Department of Energy:

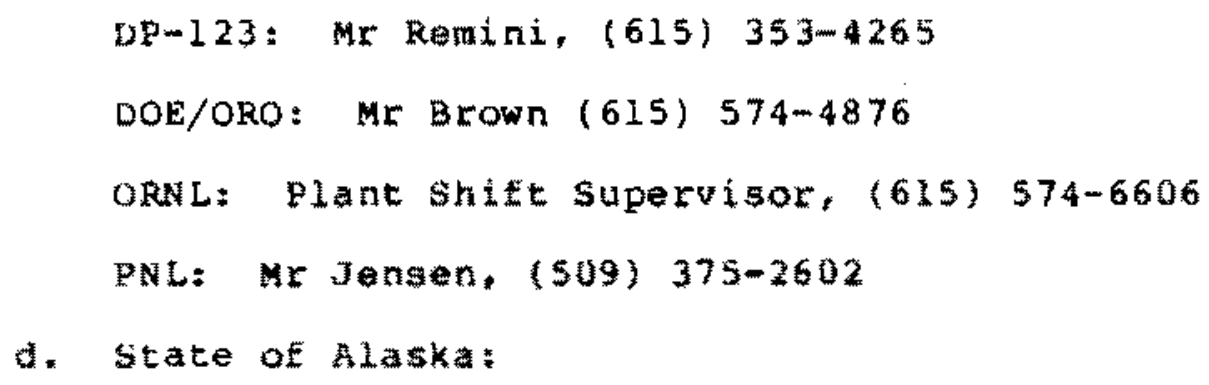


APENDIX

\section{DISTRIBUTZON LIST}

ACTTN

Ho NGE/PO

ATIN : LT COL FLORENCE

PENTAGUN, KM 2E383

WASHINGTON DC 20331

HO MAC/DEE

ATTN: LT COL EDDINGS

SCOTT AEB IL 62225

HO AAC $/ D E$

ATT: COL HODGE

ELMENDORE AFB AK 99506

HO AAC/DEM

ATTN: MAJ SXTA

ELMENDORF AFB AK 99506

HO AAC/DEHG

ATTN: MAW TULU.

ELMENUORE AFB AK 99506

HO AAC/DOOS

ATTN: MAJ RULT

ELMENDORF AFB AK 99506

AK-ARNG (OLF-G2 MAW)

176 TAG 1 CAG

ATTN: MAJ HOBBS

KULIS ANGB AK $\$ 9502$

HQ USAE/ XOORF

ATTN: COL STLICKLAND

PENTAGON RM BE935B

WASHINGTON DC 20331

HO USAF/LEEVN

ATTN: MAJ OLSUN

GOLLING AEE DC 20332

HO USAF $/$ LEEEU

ATTH: MR WORDEN

BOLLING AFB DC 20332

HQ DOE (DP-123)

ATTN: MR REMINI

GAITERSBURG DC 20545
ACTION

ERADCOM (NV \& EOL-DELNV-SE)

ATTN: MR NOWAK

FT BELVOIR VA 22050

NC-ARNG

ATTN: LT COL EVERETT

P O BOX

MORRISVILLE NC 27560

HO AFESC/RD

TYNUALC AFE EL 32403

HQ AFESC/KDC

TYNDALL AFE RL 32403

HO AFESC/RDV

TYNDALL AFE FL 32403

HO AFESC/DEO

TYNDALL AFB F' 32403

HO AFESC/DEB

TYNOALL AEB EL 32403

10 AFESC/DOM

TYNDALL AFE FL 32403

HQ AFESC/DEY

TYNDALL AEB FL 32403

1 SOW/DUX

ATTN: LT COL GAMBLE

HURLEURT AFE FL 32544

OKN L

ATTN: MR CASE

$P$ O BCXX $X$

OAK RIOSE TN 37850

Ho AMXC/SGP2

ATTN: CAPT BOLLINGER

BROOKS AFH TX 78235

ORNL

ATTN: HR $\alpha, W, H A F$

P O BOX X

UAK RIDGE, TN 37830 
DISTREBUTTON LIST (CON'T)

ACT ION

DUE / LAN L.

ATTN: MR ANDERSON (MS:C348)

P Q. BOX 1663

LUS ALAMOS NM OTS4S

NASA/JPL

ATTN: MR RUSCHAE (MS:507-228)

PASAOENA CA 91109

DOE / PNL-BATTLLLE, NN

SATIELLE BLVD

ATTN: MR JENSEN

RICHLAND WA 99353

DOE/DNL-WATTELLE OF ALASKA

101 W GENSON, SUTTE 305

ATTN: MR PERRIGU

ANCHORAGE AK $\$ 9503$

SCATE OF ALASKA

DOT/PE (ATTN: MR LEONAKD)

2301 PEGER RD

FAIRBANKS AK 997U1

HO $M A C / X P Q T$

ATTN : MAN OERTEL

$S \operatorname{COTT}$ AFE IL 62225

HO $\mathrm{MAC} / \mathrm{XWS}$

ATTN: MAJ HASTIHGS

5 COTT AED IL 62225

USAFALEENT/RA

ATTN : MAJ JUNES

POPE AFE NC 28308

HO MAC/DOXT

ATTN: CAFT NELLIS

SCUTT AEE IL 62225

HO MAC/DUXS

ATTH: MAJ GOLLEY

SCUTT AFB IL 62225

HO ARRS/DURO

ATTN: MAJ FARACE

SCOTT AEE IL 62225
ACTION

DOE/ORO

ATTN: MR BKOWN

P O BOX $E$

OAR RIDGE IN 37830

USAF-OEHL/RZT

ATTN: SMSGT HARVEY

BROOKS AFB TX 78235

INFORMATION

ESC/SCU -5

ATTN: CAPT TUSTIN

HANSCOM AFE MA 01731

USA-NATICK LABS

ATTN: DR R S SMITH

KANSAS ST

NATICK MA 0176U

USA-CRREL-EE

ATTN: MR WOURI

72 LYME KD

HANUVER NH 03755

HODA (MA-WSA)

ATTN : MAJ BELL

EENTAGON, RM 38454

WASHINGTUN DE 20310

SAE/MII

ATTN: MAJ KROOP

PENTAGGN, KM 4C940

WASHINGTON DC 20330

HO USAF/LEYSE

WASHINGTUN DC 20330

HO AFSC/DLWH

ATTN: CALT REED

ANDREWS AFB MD 20334

HO AFSC/SDN

ATTN: MR MILLER

ANDREWS AFB MD 20334 


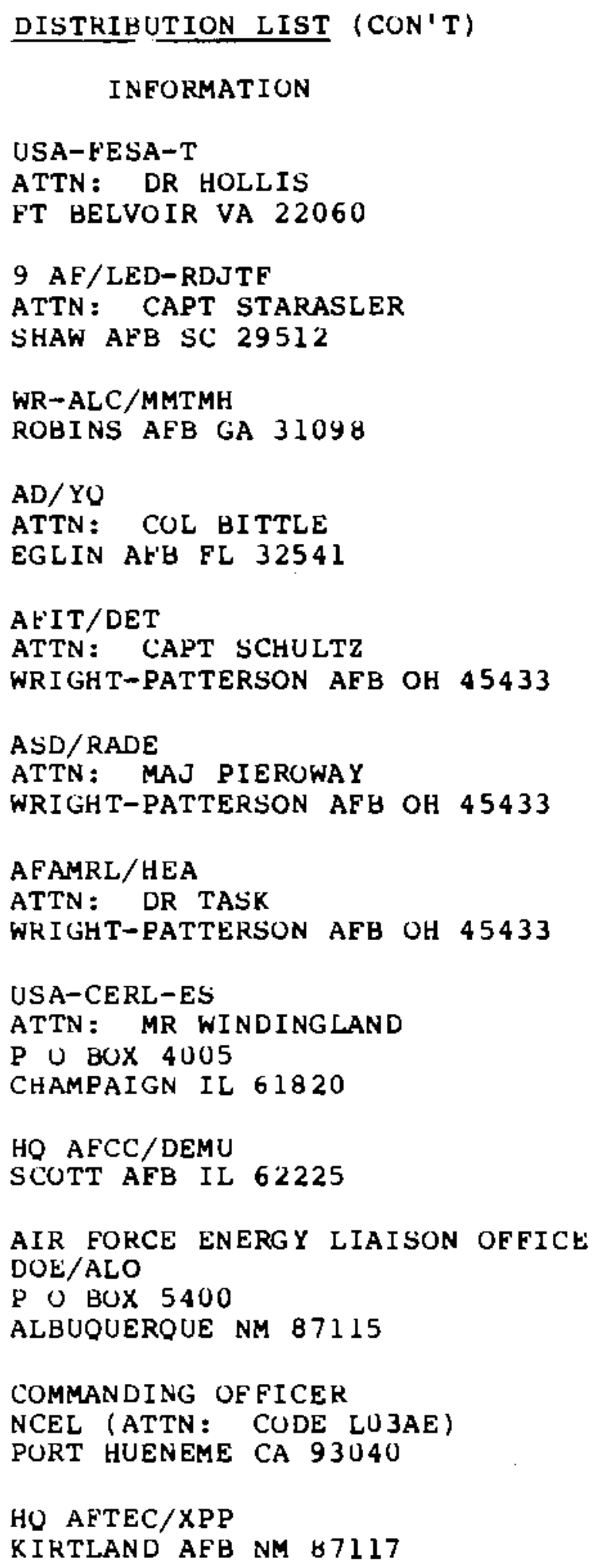




\section{APPENDIX VI \\ STATE OF ALASKA \\ TEST PLAN}

\section{Evaluation of :}

\section{Radioluminescent (RL) Airfield Marking System}

Location and time:

Field test at Central, Alaska. Period from December 13, 1983, to February 15,1984 .

Equipment to be evaluated:

1. Radioluminescent airfield edge and threshold second generation lights with prototype fixtures and semi-permanent base mount systems. Some of the first generation lights may also be used it deemed necessary.

2. Radioluminescent portable glide slope landing aide contingent on availability.

3. Radioluminescent airfield wind direction indicator. Objectives:

To evaluate, in an operational environment, a usable, self powered lighting system designed for remote airfields. The system must be operationally simple wtih low maintenance requirements and realistic cost potential.

\section{SCHEDULE AND UESCRIPTION OF EVENTS}

Upon selection of a bush airfield:

1. Alaska Department of Transportation and Public Facilities (DOTPE) personnel will notify appropriate airport maintenance 
personnel on selection of runway for RL light test. Maintenanoe personnel (either contract personnel or direct state employees) will be instructed as to necessary inspection checks we will require for lights. They will have easy access to DoTpF/DOE Laboratory personnel if any problens arise with the systen in the absence of DoTrF/DOE Laboratory personnel. "(Completed as of October $1 * 1983)$ weather data will be compiled daily by Dotpg/ooe Laboratory personnel. Data to be collected will include:

a. Outdoor temperature.

b. Wind direction and speed.

c. Ambient light conditions.

a. Precipitation.

e. cloud cover.

2. Village concil and mayors will be informed of test program and briefed on the lighting systa. If the village is receptive to the light test in their location, a "Public Relations" program w1 go into effect in which all village citizens, young and old, wil be informed of the importance of the runway lights to their commuity and what level of risk the Rl light system presents. Items to be covered in the briefing will include:

a. RL light safety features.

b. Effects of breakage of RL lights (health-physics).

c. No external power source, therefore, low maintenance.

d. Importance of scheduled air travel to bush in wintex. (Completed september 8,1983$)$ 
3. DuTpr personnel will coordinate with raA on notification of air carriers and urivate pilots of the test lighting system. completed september 22,1983 )

4. Letters will be sent to the following groups of people to inform them of the test location and duration. Their participation to viewfevaluate the light system will be encouraged.

a. Alaska Department of Transportation and Public Facilities personnel.

b. EAA personnel.

c. State legislators.

d. Canadian Degartment of Transportation,

e. Air Carriers Association representatives.

f. Civil air Patrol (CAP) personnel.

g. U. S. Navy.

h. coast Guard.

i. Army Guard.

J. Air cuard.

5. scheduled bush air carriers and airlines for the village wil be briefed on the lighting system - - a special briefing will be given to interested pilots (private and commercial) on how the lighting system works and how the lighting system would be perceived by a pilot (alides and other video aides will be used). Nawspaper ads and radio shorts will be used to notify pilots of the briefing location and time. 
6. Pilots will be infomed that we would appreciate all comments, either positive or negative, or phone or mad, on the ingliting system after they have flown to it. Evaluation sheets will be provided for pilots prior to gystem installation. A system of evaluation form distribution and retreval of completed forms will be organized.

Septerber 1983

base mounts for light fixtures will be installed at gelected brush airfield location by DorpF personnel. $($ See figures 1 and 2 for Eixture and base mount degign as suitable lternatives). November 1983

Un November 1-4 DOTPF/DOE Laboratory personnel will briet the Technical Working Group (TGC) on the state of Alaska's tests. Identifying all details and points of coordination necessary. Noyember $13-22$

At Allen Arny Airtiela DOrPF/DOE Laboratory personnel will ot ter assistance where needed to the DoE/Air force personnel. Also during this period DOTPE/DOE Laboratory personnel will make adjustments to the lighting contiguration to allow FAA light standards inspectors to Ely against the lights in a light aircrat. FAA wil eyaluate three separate configurations as shown in figures 3, 4, and 5 . This operation should be accomplished during one evening of testing. Exact schedule will. be developed during the Novenber 1-4 neetings at camp Hokall. 
Novenber $22-$ Decenber 13

buring this period CAA will be requested by state of Alaska to adopt procedure to allow commercial and/or private pilots to utilize the lighting system once it has been installed and accepted at Central, Alaska.

December 1983

Alaska Air National Guard (AKANG) C-130 Transport will arrive at Central with cargo of RL lights, fixtures, and ancillary equipment.

WutE: It preassembly of light fixtures is recuired before lights arrive at Elnal bush atrield demongtration location the above will occux along with the following steps.

1. DUTPE/DOE Laboratory personnel wil meet C-130 and offload equipment to ground trangportation. Equipment will be taken to Soure warm storage and assembly areat dotpe facility, 2301 Peger Road, Fairbanks, AR, of other approved location. 2. Assembly of RL lights and fixtures wil commence* NoTE: If preassembly is not required the tollowing will take place.

December 1983

1. Lights will be transported to bush arfield location at Central, Alaska, via AKANG C-130 airoratt.

2. Light system wili be mounted on preset base mounts.

3. Test landings and takeofts will be made to the newly installed light system. Deficiencies will be corrected at this time. FAA will cooperate here. 
Nowe: All shipping containers for the lights wil be gtored at a secure DorPe or other approved facility at central throughout the duration of the DUTPE test.

At least one DUTPF/DoE laboratory personnel will remain at the runway location for up to one week upon deployment of the lights. Travel inspection/evaluation trips to the village will be made weekly or as needed after initial acceptance of the lights. Any changes in light configuration throughout the duration of the test will be agreed upon by both DoTPF and kAA personnel. The USAF, AAC, AKAKNG, ARANG, and CAP aircrat and personnel will be encourayed to Ely to Central to viow and evaluate the lights throughout the duration of the state's test. A questionnaire will provlde a data base for this aspect of the tast. Also a cost analysis by the comnercial carriers will be requested to determine the impact of the lighting system on their respective operations. Januax $16-20,1983$

One or more days during this week will be 3 et aside for a presentation on the RL lighting system for USDOE and Alask DuTPF personnel. A field trip to central to view the lights will also be scheduled during this time for others primarily interested in civilian uses of RL airtield lighting systems.

Eebruary 1994

Upon completion of DuTpt"s portion of the test, the AKARNG and/or AKANG will be called upon tor air support to return the lights to secure storage in Anchorage or Fairbanks pending instructions from Dut: 
Any adnormalities in the light system which can be easily remedied will be corrected at this time. The lens covers will be cleaned as needed.

February 15,1984

The lights will be made available to the AAC for their continued testing.

A pilot debrieting and critique will be held following the removal of the lighting system. Newspaper ads and radio shorts will be used to notify pilots of briefing location and time. Upon completion of the test, a meeting will be held in Central to get feedback from the DOTPF maintenance personnel and residents of Central on their perceptions of the RL runway lighting system. During the spring of 1984 all data will be compiled and a report written. 
RI FIXTURES FOR TEST AND EVALUATION AT CENTRAL, AK DEC THRU FEB 83-84 PANEL MOUNTED FIXTURE

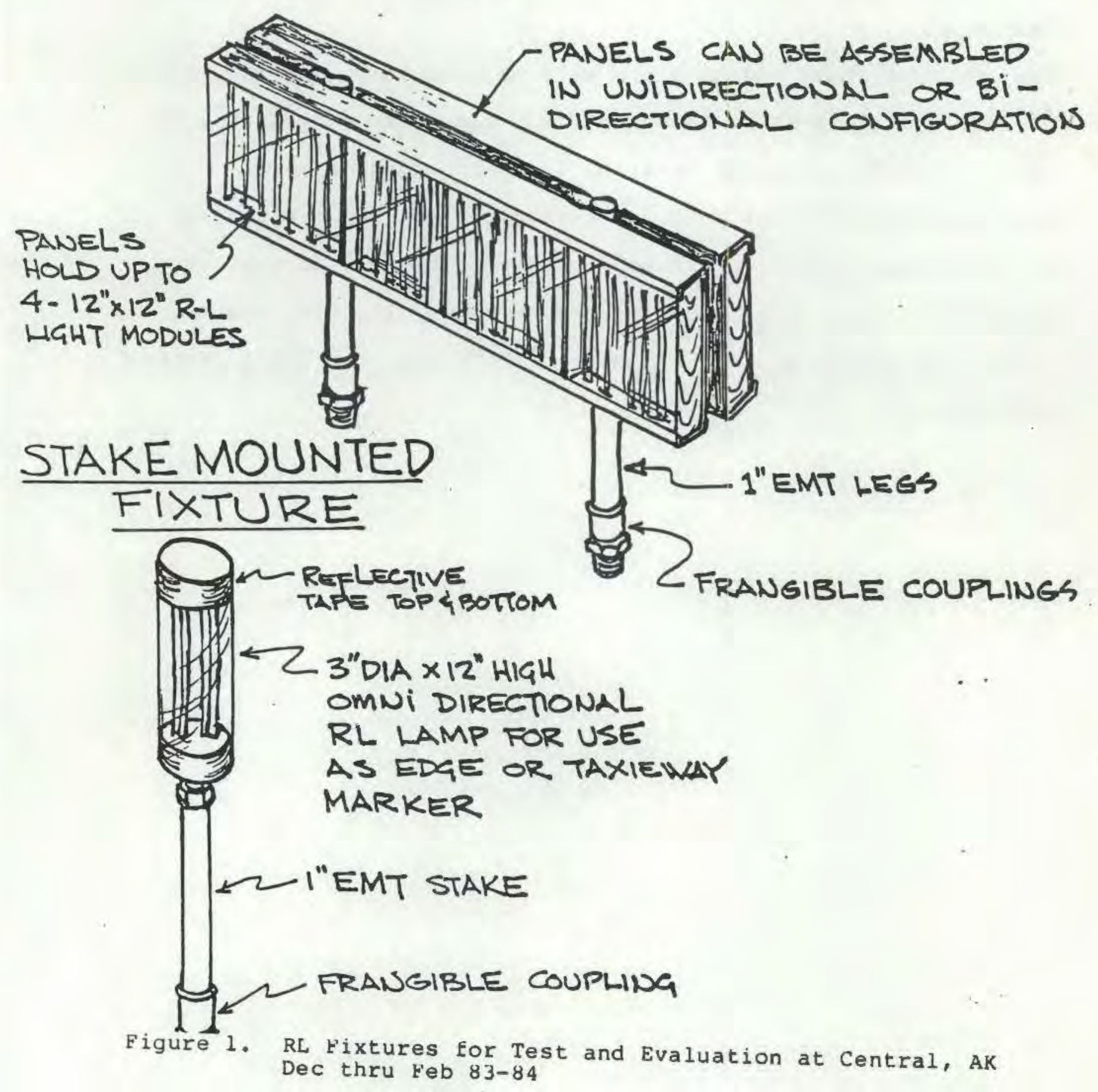


RI LIGHT BASE MOUNT

DRILL HOLES

TO RECEIVE

3/8 DIA SPIKE

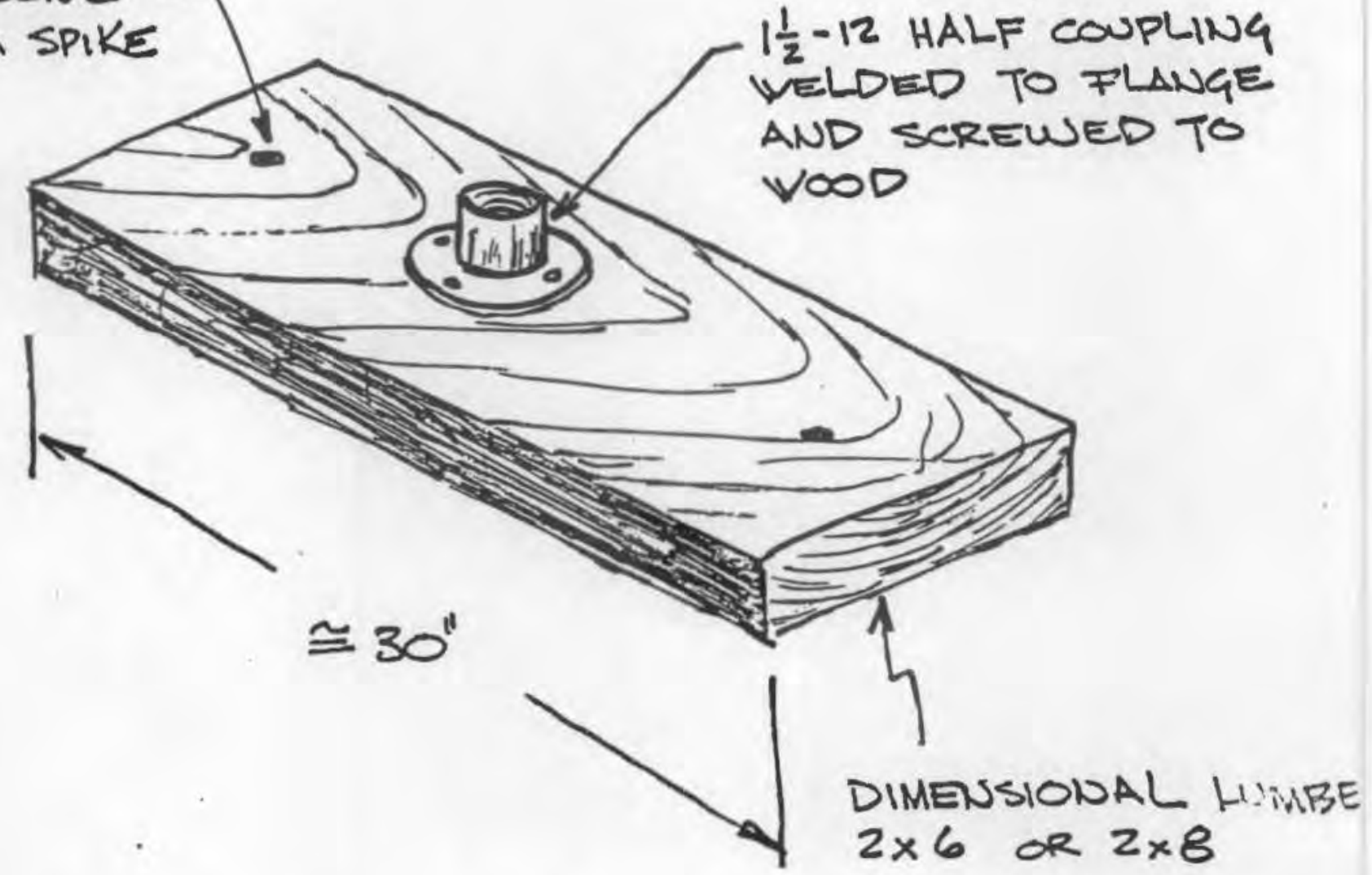

1-PIECE REQUIRED FOR EACH STAKE MOUNTED REL LIGHT UNIT

2-RECES REQUIRED FOR EACH PANEL MOUNTED REL LIGHT UNIT

Figure 2. RL Light Base Mount

$4 y$ 


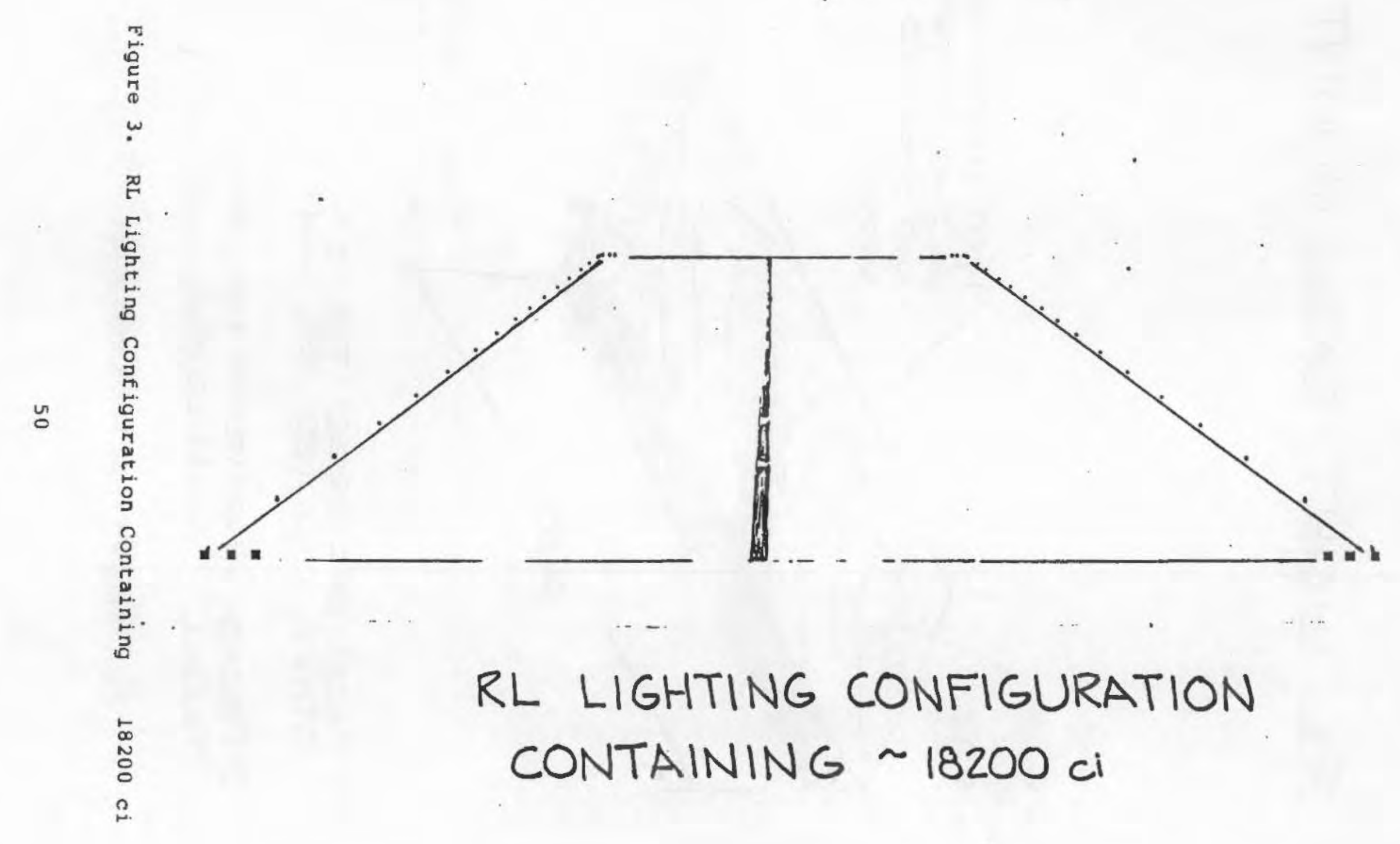




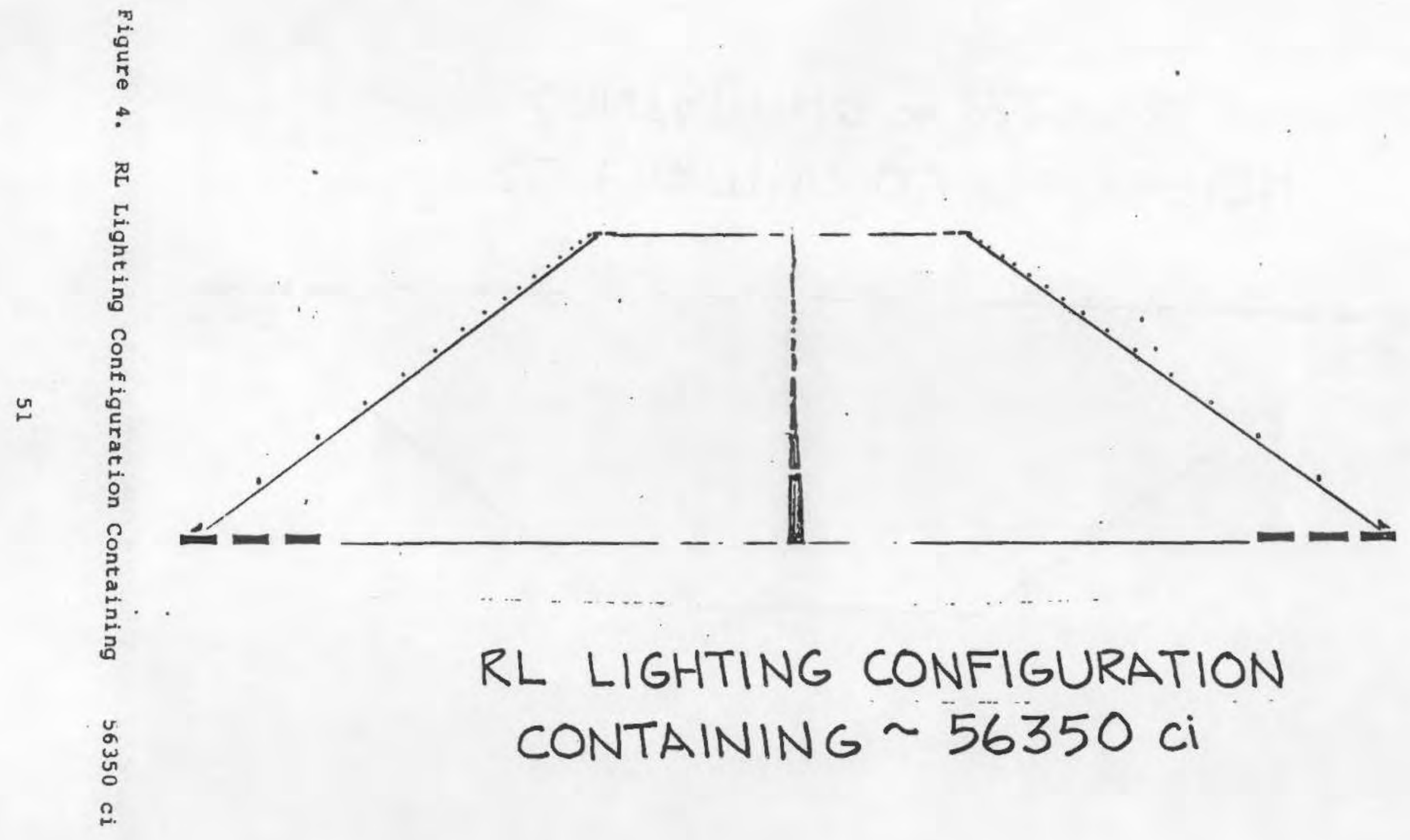




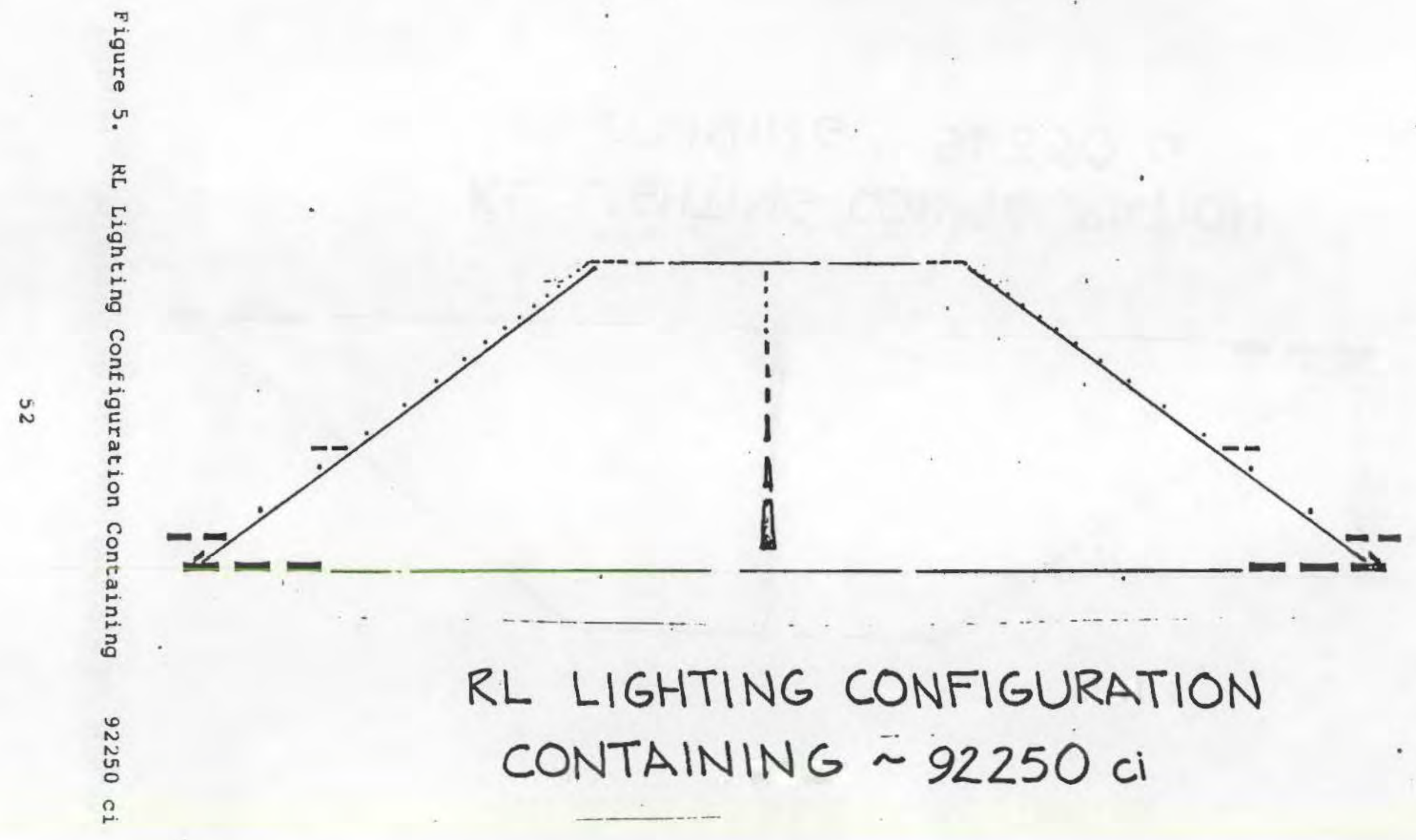




\section{ANNEX I}

EVALUATION OBJECTIVES

1. Identify and evaluate human factors and cold climate engineering variables aftecting the deployment, operation and maintenance, and redeployment of tritium lights and fixtures for different arctic and subarctic applications, including:

a. Ease and safety of storing and transporting the lights and $\mathrm{f}$ ixtures.

b. Ease and safety of fixture handing while encumbered with arctic clothing for extreme cold, wind and snow conditions. c. Suitability and adaptability of fixture supports for temporary installation (freezing and/or staking to ground) and effectiveness of $\mathbf{t i x t u r e ~ b a s e s . ~}$

d. Installation and removal time requirements.

e. Maintainability, to include cleaning the lights and Eixtures.

f. Ability to stand up to weather, propeller and jet blast effects.

2. Evaluate the physical and environmental safety and security of RL lighting applicable in remote arctic operations. 3. Evaluate security precautions to preclude thett and/or destruction of the lights.

4. Identify and evaluate visual slant range at which pilots acquire the tritium lights. The improved RL airfield lighting system should have a 4-6 mile acquisition range. This is to be verified by each aircrew. 
5. Evaluate pilot views of tritium ifghting as ald for approach, landing, wollout and takeoft.

6. Evaluate capability of a VAsI system to provide glide slope information to pilots.

7. Assess overall adequacy of tritium lighting to support a variety of aircraft and operations in an arctic and subarctic envi ronnent.

8. Provide individual andor group recomendations to enhance any aspect of light utilization.

9. Ground support briefing to be conducted by responsibility of AXC/DEMG. 
ANNEX II

BRIELING HANDOUT ON

TRITIUM RADIULUMINESCENT (RL) PORTABLE LIGHTING

\section{BACKGROUND}

Radioluminescent (RL) lighting is definod as the use of radiation from radiolsotopes in combination with phosphors to produce visible light. Radioluminescent lighting has ben used in industry for clock dials, ext signs and light standards in the photographic industry. The military has used light-emitting paints for aircraft dial illumination, mine fiold markers, and gunsight illumination.

Within the last several years joint Dod/Doteffort has been inderway to develop tritium RL lighting for airfield application. A Eirst generation of tritium lighting was evaluated at clear Creek, tz during BRIM FROST 93. These lights proved to have a visual acguisition range of one to two miles which was suitable only for slow moving aircetat.

Since then, comprehensive engineering eftorts have produced a significantly improved runway light. It is anticipated this light can be acoured by aircrews between four to six miles, Which is suitable to support $c-130 / n-10$ type aircraft operations *

Certain known techniques may be used by participating pliots to inprove acquisition of the lights, wuch as keeping cockpit/cabin lighting to an absolute minimum, and not staring at the tritum 
1iuntg; viewing alightly so the gide may improve acuuisition. Aso helptul is not turning landing lights on until short final, as they tend to wash out the test lights.

One final reminder - Tritium lights ate not incandescent. They give of a smooth glow rather than a bright point light. Atcached are specitic procedures to tollow during the test and a questionnaire to be compleced. 
ANEx II

PQOCEDURES ROR A-10 EVALUATION

OF TRITIUN RL RUmWX LIGHTS

1. A primary wotive bohind tritlum lighting development la the enhancowent of tactical operations at bare bases, espocially in the arctic environiment.

2. It le extreinily boportant that $x-10$ pllots have the cpportunity to evaluate the tritium runway lighting and its capability to support their mission.

3. Pilota wil receive a brieling pelor to their firat flight.

4. A waxinum minber of pllote li dosired, but an individual pllot ay fly wore than one tout sortie.

5. At least two sortion are desirad datly (1600t-2000L).

6. Aircratt W11 dopart Bielson AFs to arrive at Allen AM between 1600 and 1900 local with auficient intervals to allow. timm for low approaches and landinge.

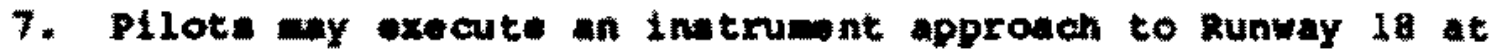
M1Len MAP, MK.

8. Pilot: any axecuto viaual approaches if wathor condition allow VPr operations.

9. Pilot: will oxecute at leat one mised auprocoh/low approuch prior to full stop landing:

11. Prior to all etop landing the pllot vill recelve the current wather condition including an eccoptable runway condition Feading (RCR) frow the test trana. 
1. Final decision to land will cemain with the pilot - SAFETY WILL NOT EE COMPRUMXSED.

12. After landing, the aircraft will be taxied to the specified parking area and shut down for mandatory brake cool period. 13. If possible, pilots will be verbaliy debriefed by the test tean.

14. A-10 aircrate will then take off, make one additional low abproach and return to Eielson AFB*

15. pilots and ground support crews will complete questionnaires and ceturn them to the project officer. 
ANNEX IV

PROCEDURES FOR C-130 DEVELUPMENT TEST

OF TRITTUM RUNWAY LIGHTING AT OUNNELLY LZ

1. Portable, dependable airfield lighting is a nacessary asset

in the successful accomplishment of the tactical aiflitt mission.

2. It is extremely important the C-13u pilots have the opportu-

nity to evaluate the improved tritim runway second generation

tritium lighting and its capability to support their mission.

3. The $616 \mathrm{MAG}$ wil appoint a project officer to coordinate all

test requirements and ensure participating $c-130$ aircrews are

oriefed and debriefed.

4. C-130 aircrews will receive a thorough brief prior to their

first tight and receive questionnaire handout package.

5. Pilots willile a flight plan and fly their alcerate to

Donnelly, L2 IAW nomal MAC and ATC operating reguirements and proceduress.

b. Pilots will align the aircratt on the extended runway centerline, at least Eive nauteal miles from the cunway threshold to begin a staight-in approach.

7. Pilots w11; as accurately as possible, document the maximum distance at which the lights are acquired, usable distance, glide path intormation, and other data required by the arrocew questionnaire. 
9. Low approaches/missed approaches will not be planned in supuort of the tritium test.

9. Pilots may request that conventional runway lighting be curned on anytime they feel safety may be compromised.

10. Pilots will complete the questionnaire and return it to the unit project ofticer. 


\section{ANNEX V \\ TRITIUM RUNWAY LIGHTING}

\section{A I RCREW OUEST IUNNAIRE}

Instructions: This questionnaire shall be completed as soon as possible after viewing the test lights. Please identify acquisition distance for each approach made. Return to your project officer or return to: HO AAC/DOOS, Elmendorf AFB AK 99506. When evaluating the RL lighting system (RLS), use "outstanding" as if you were evaluating an excellent incandescent system. A satisfactory system will be your opinion on an acceptable airtield lighting system.

1. General
A. Approach tlown: VOR NDB TACAN Visual
B. Maneuvers: Low Approaches Landings
C. Have you flown approaches and/or landed at this airfield No before? Yes

II. Weather Conditions
A. Cloud Cover: Scattered Broken Overcast
๖. Ceiling/Visibility: Height AGL; Distance nm
C. Precipitation: Snow Fog Haze None III. VASI Landing System

A. Maximum Acquisition Distance (each approach) $\frac{1}{2} \frac{5}{4} \frac{6}{6}^{\mathrm{nm}}$ 
B. At wat distance did the VASI provide usable "glide path" information? (each approach) $\frac{1}{2} \overline{3} \frac{4}{4} 6^{- \text {nm }}$

C. How was this distance measured? leach approach

Estimated

Radar

DME

Chart

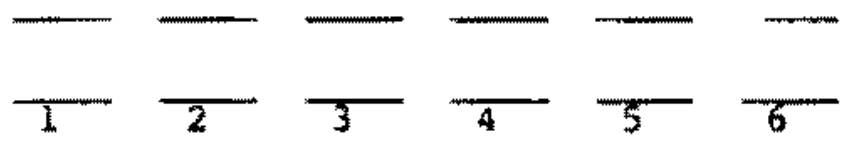

D. Rate the VASI for overall performance an providing runway end acquisition and glide path information: outstanding Excel lent satistactory Marginal Unsatisfactory

IV* Threshold Runway Markers

h. Maximum Acauisition Distance (ach approach)

$T-\frac{2}{3}-\frac{}{5}-\frac{6}{6}$

9. At wat distance did the lights aid in runway alignment? (each approach) T $-\frac{3}{2}-\frac{5}{6}-\operatorname{man}$

C. How was this distance measured? (each aporoach) Estimated a) dar

DME

Chart

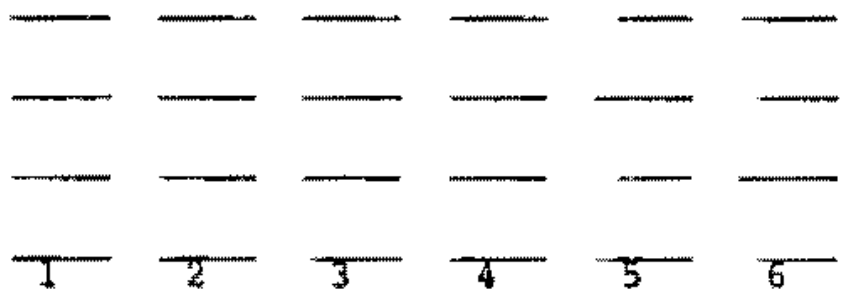


D. Rate the threghold and edge lights for overall

performance: Uutstanding __ Satistactory __ Marginal __ unsatisfactory

v. Edgelights Runway Marker Lights

A. Maxinum Acquisition Distance (a ach approach)

$\pi \frac{2}{3}-\frac{5}{5} \frac{{ }^{n}}{\text { nn }}$

E. At hat distance did the lights ald in runway alignment? (each approach) $\frac{}{1}-\frac{}{3}-\frac{5}{5} \frac{{ }^{n}}{n}$

C. How tas this diatance measured? (each approach) Estimated Radar

DME

Chart
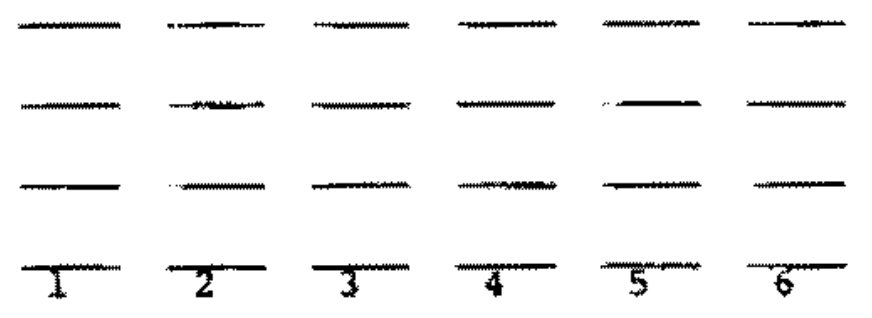

VI. Landing/TakeotE

A. Could you identify the entite landing/rollout/take of area using the test lights? Yes _ No _

3. Did the test lights provide similar visual cues (i.e., petineral vision, depth pexception, etc.) as conventional lighting? Stimlar Diterent Better than As yood as Not as good as

Comments: 
VII. Conclusion:

A. Does the RL lighting system (RLS) meet your redulrethents as a landing, collout, and takeof aid? that recommendations would you make to improve upon this system? please write your answers to the above questions and any additional comments approprate regarding the RLs.

B. Name:

Ramk:

Organization: woration:

C. Telephone (mutovon and commereal):

D. Tyee airerate flown:

E. Astrew duty status: $\mathrm{CP}$ Other

* Aircrew aviation experience years ingt hours

G. It observer: Type aircratt: Have you evaluated RLS before? Yes No

VIII. Your cooperation and support is appreciated. please turn in questionnaire as reguested in the coordinating instructions. Your input is essential: 


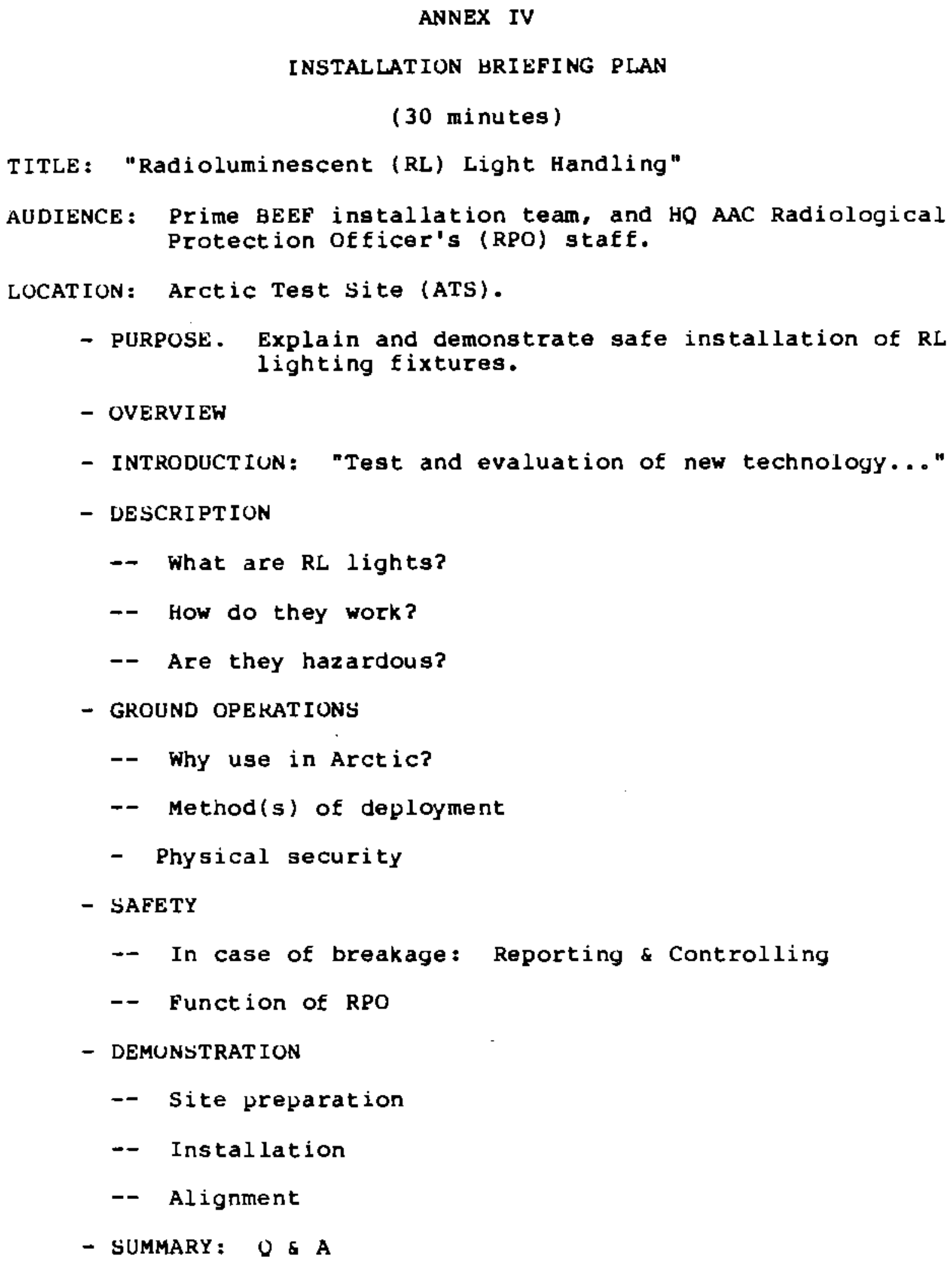


ANNEX VII

TRITIUM RUNWAX LIGHTHG

GROUND SUPPORT CREW QUESTIONNAIRE

The RL lights to be used for USAF leld teats in Alaska during the tall and winter of 1983-6 are experimental devices. of importance to these fall and winter tests are the ase and efticiency with which they can be deployed redeployed, used and stored. Key factors affecting these four operations are handleability, materials petormance, attachment, removal, assembly, disassembly, dusting, condansation, wing and matintenance under the Hidd conditions in wich tney w11 be tested. Instructions: Please complete this questionnaire as soon as possible after conducting one of more of the following operations:

(1) storing, (2) deploying, (3) redeploying, and/or (4) observiny operation of the tritium RL lights. Limlt your comnents to those questions that address the activities in which you were uersonal1y involved.

1. Type of Operation

A. Storing

B. Deployment

c. Redeployment

D. Operations/maintenance

iI. weather conditions

A. Surface temperature

B. Surface wind speed Direction 


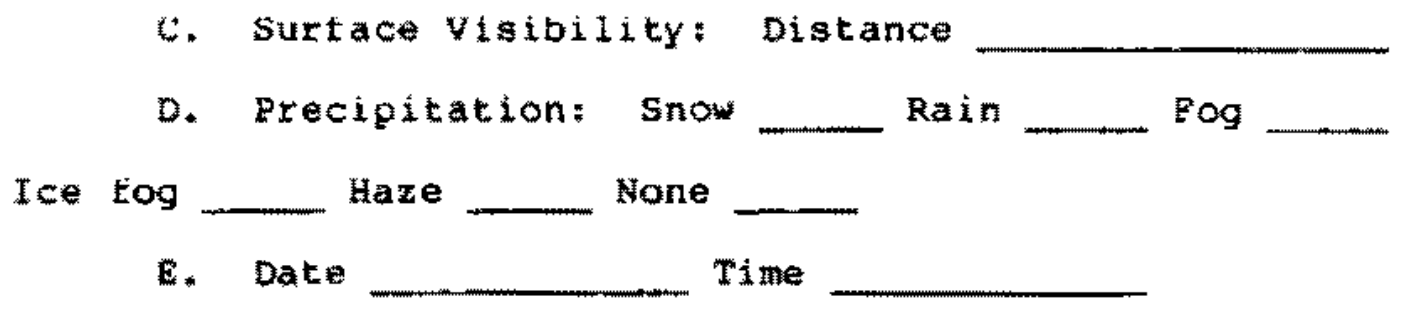


11. VAsil Landing system

\section{Qutstanding Excellent Satisfactory Marginal Unsatistactory}
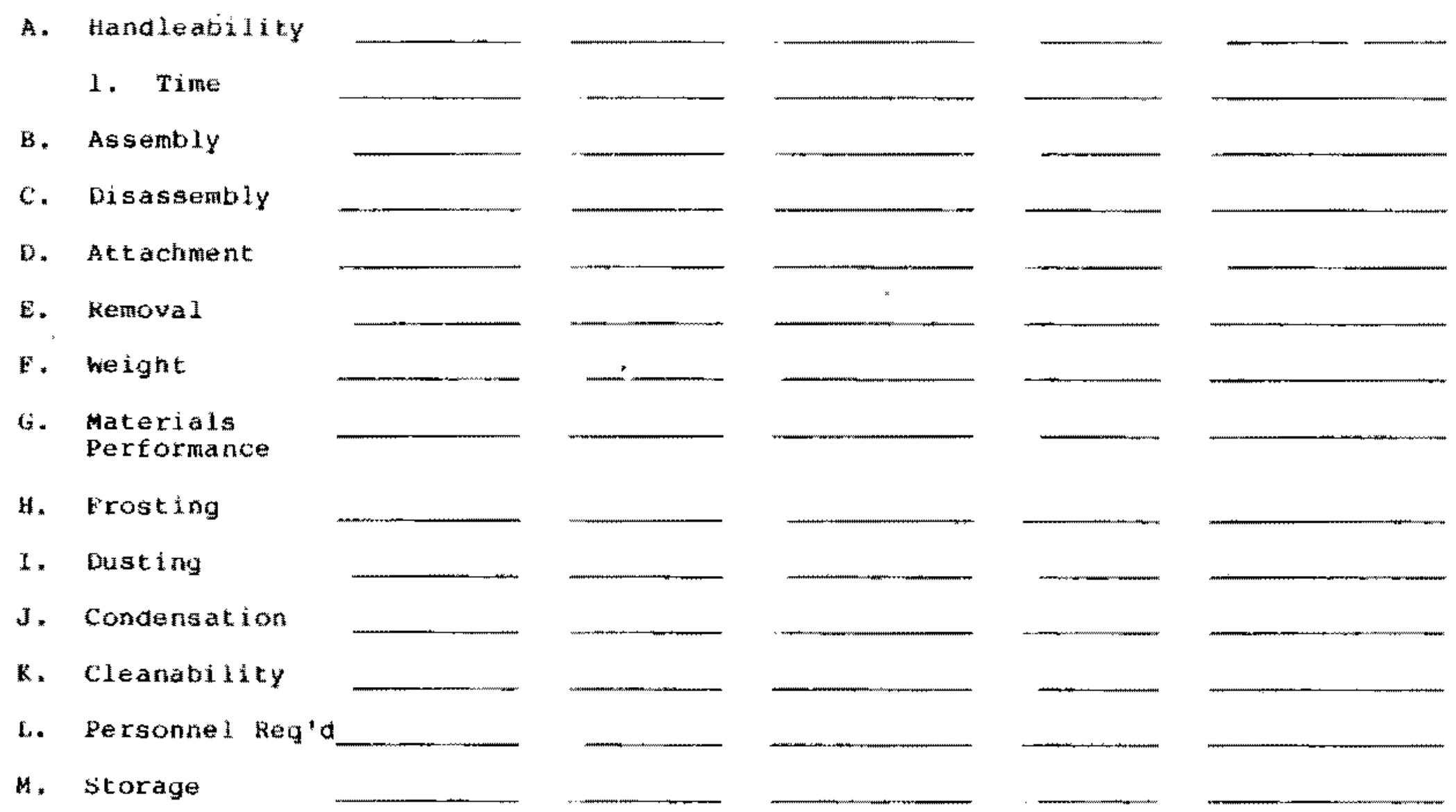

When evaluating $H, T$, J consider equiument desiuns ability to limit each characteristic. For $L$ it is outstanding when system requites less than conventional system, and more would be unsatistactory. 
IV* Thresnold Lights

\section{Gutstanding Excellent Satisfactory Marginal Unsatistactory}
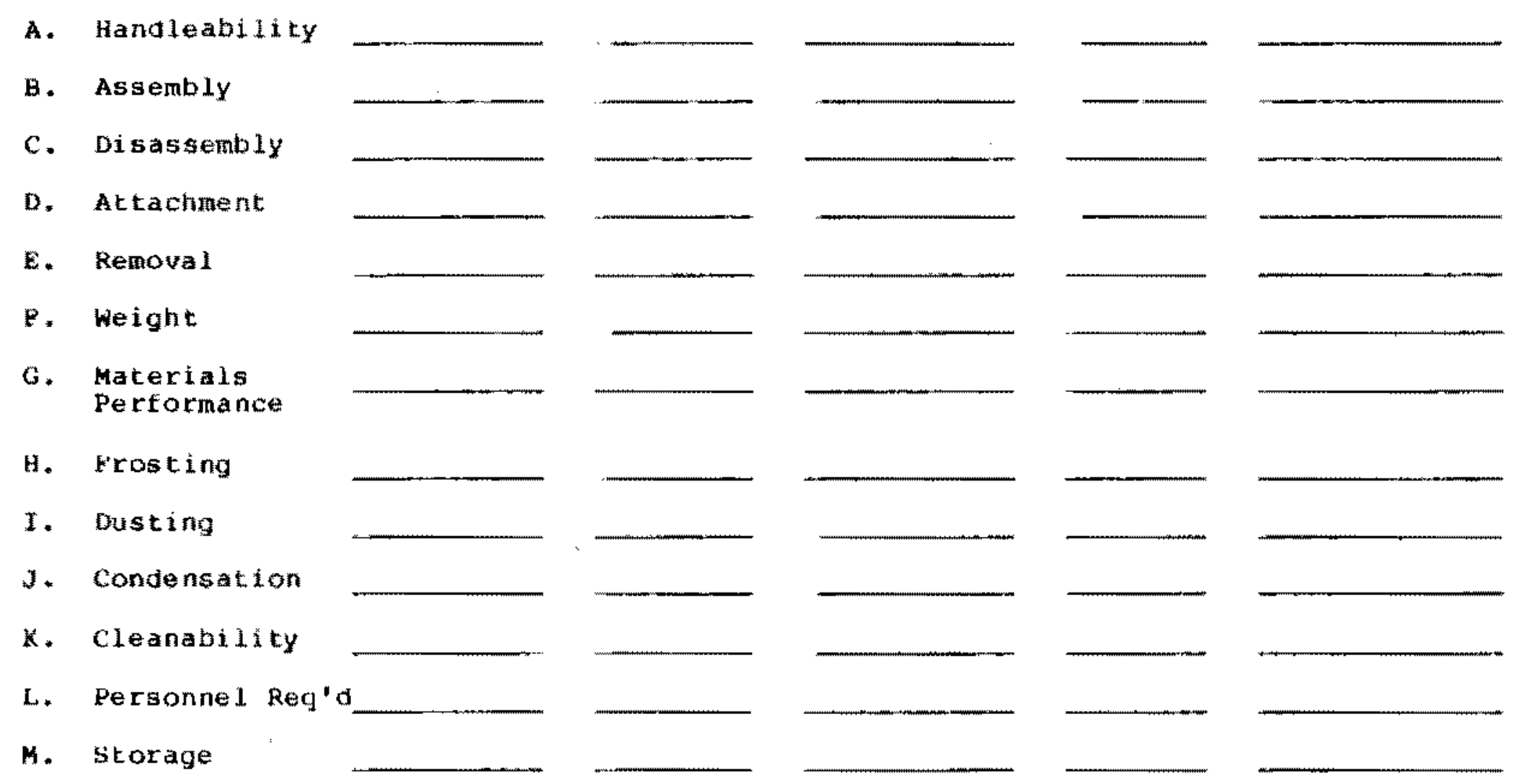

When evaluating $H, I$, J consider equipment designs ability to limit each characteristic. For $L$ it is Outstanding when system requires less than conventional system, and more would be unsatisfactory. 
*. Edge Lights

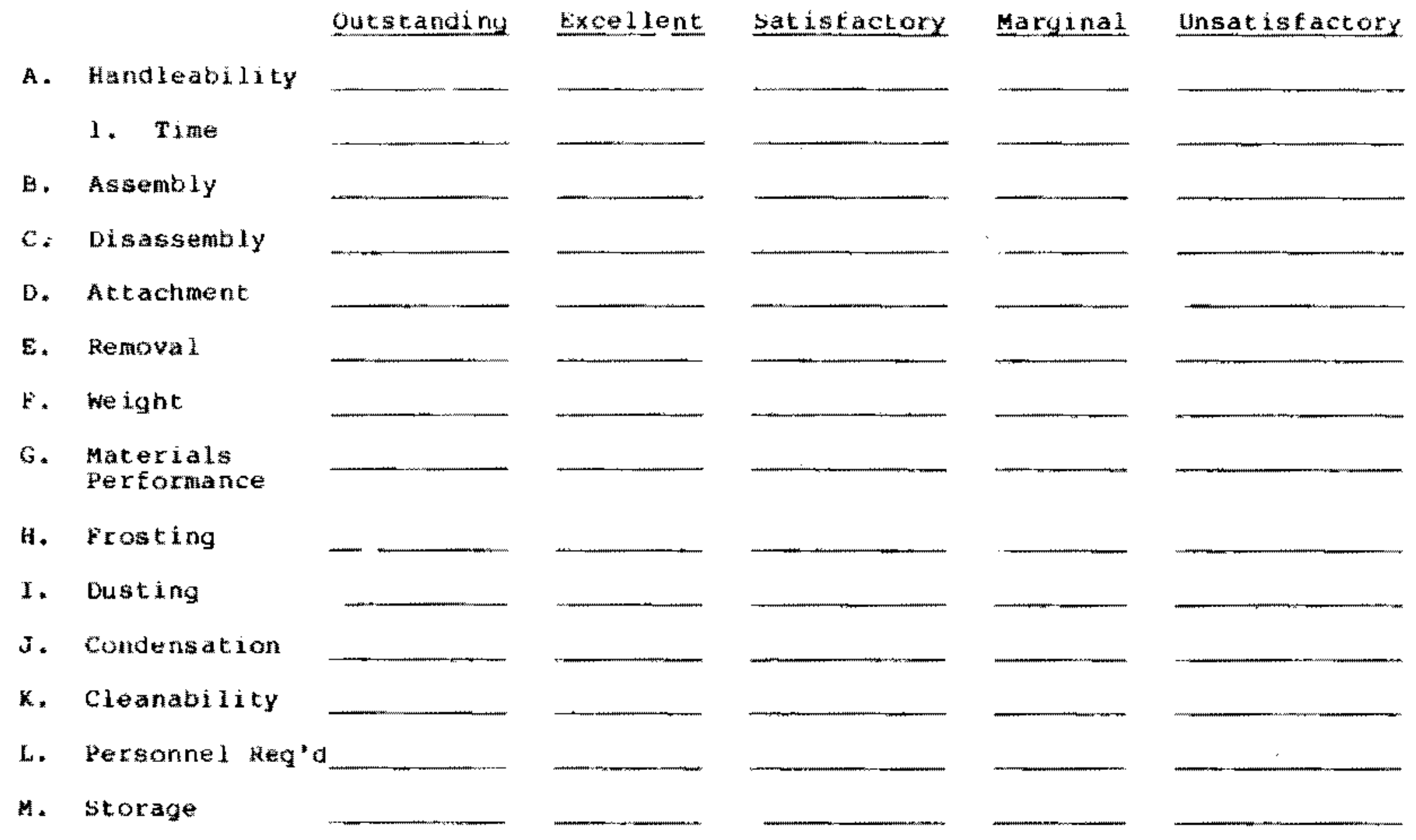

When evaluating $H, I, s J$ consider equipment designs ability to limit each characteristic. For L it is outstanding when system requires less than conventional system, and more woula be unsatistactory. 
VI. Conclusions and Recomendations

A. Give your overall evaluation of the ease of storage deployment/redeployment/use of the tritium RL lights.

B. List any suggestions you may have for improving the design and use of the RL lights (handling storage, etc.).

VII. Responder

Name

Rank/Rating

organization

Location

Telephone Number 
ANNEX VIII

TERMS, DEFINITIONS, ACRONYMS

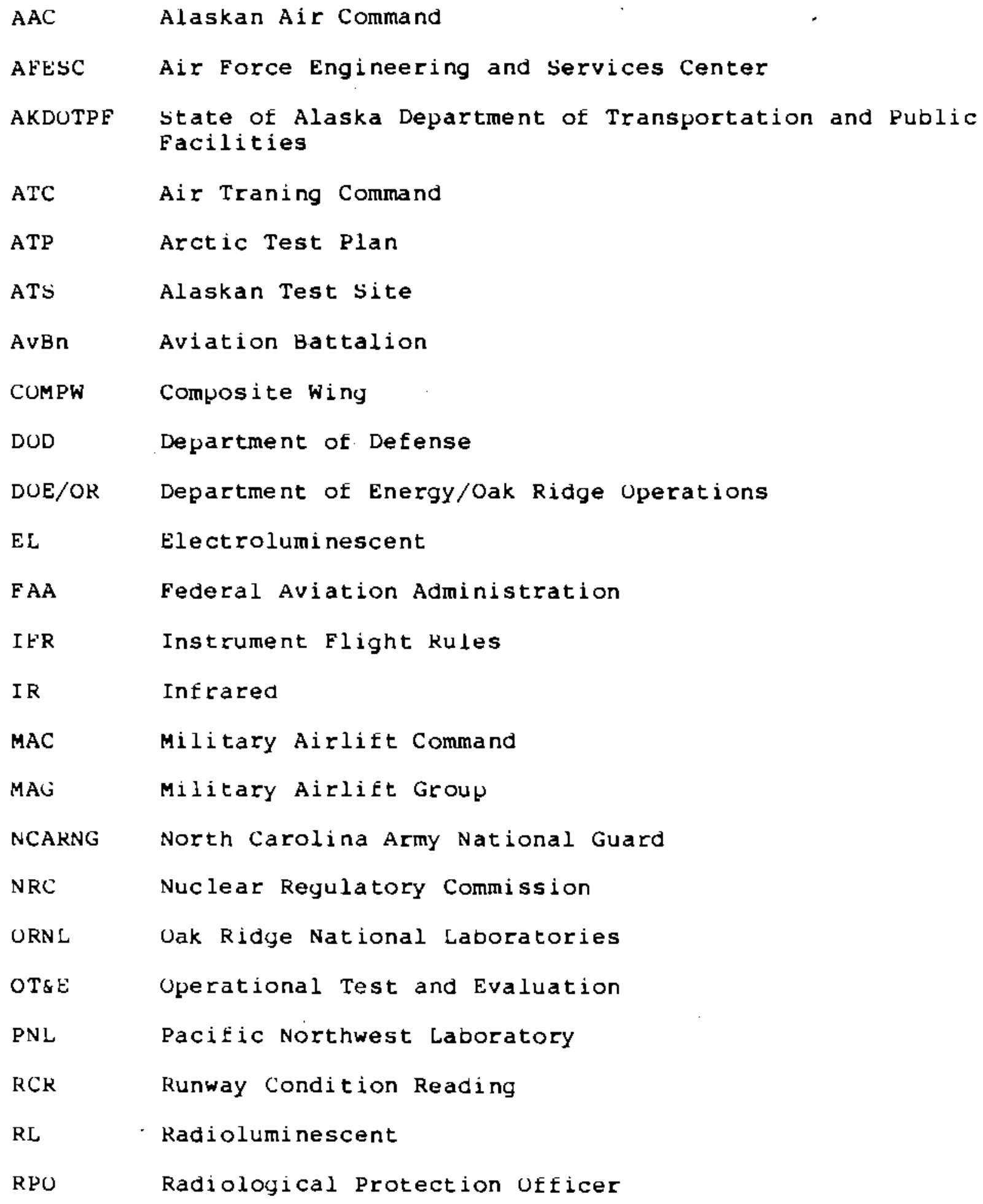




\begin{tabular}{|c|c|}
\hline Rite & Kunway surtace Conditions \\
\hline TACAN & Tactical Aid to Navigation \\
\hline TAG & Tactical Airlite Group \\
\hline TFW & Tactical Fighter Wing \\
\hline ToLs & Tactical ogerating Locations \\
\hline $\mathrm{UHE}$ & Ultra High Frequency \\
\hline USAF & United States Air Force \\
\hline USCG & United states coast Guard \\
\hline VASI & Visual Approach Slope Indicator \\
\hline VFE & Visual Flight Rules \\
\hline YHF & Very high Frequency \\
\hline
\end{tabular}


. 
APPENDIX B

COMMERCIAL PRODUCERS OF TRITIUM LIGHTS IN

THE UAITED STATES AND EUROPE 


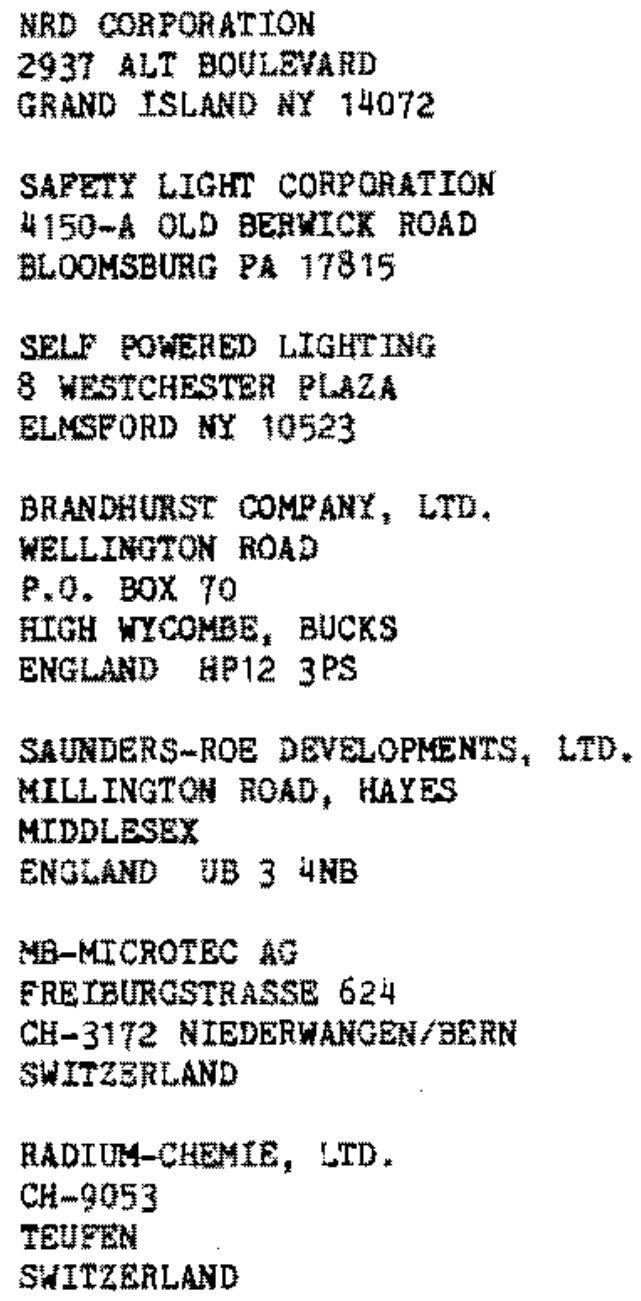




\section{sattelle \\ Paciffic Narthwest Laboratories P.O. 990

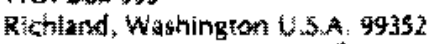 \\ resephorie 15091 373-2502 \\ Telex 15-2074}

June 28,1983

SAMPLE UETER REQUESTW INPORHATION

SENT TO FIRMS LISTED ON PREVTOUS PAGE

Gen: Lemen:

We are currently working with several organizations to evaluate and further develop self-contalned If ghting for a variety of purposes. As a part of this effort, we have a commlutent to assess the state-sfthe-art for the use of radioluninescent lighting for airfleld lighting and working purposes such as runuay edge, threshold and taxiway lighting. Use of this lighting would be in remote and rurai areas where comnercial electric power is unavaliable, unreliable or extremely expansive.

Prototyse systems as they exist now requlre further development or modification before operational designs for routine uge are avallabie; however, to evalwate the state-of-the-art, specifie information such as the following wouk be userul:

- Could Industry provide a light of sufficient intensi ty to be useful in thts appilication?

- That would be required to produce such a light and what would be ita cost?

* Would the light be drectional, bidrectional or omidirectional?

- Is there scaething in exjsting product lines which wouta be suit table?

- What are the coreseen ingtitutitonal probiems such as licensing, public acceptance, etc.? 
June 28, 1983

Pase 2

\section{\$Battelle}

While these are not all the questions that should be addressed, they are representative; and any information you could provide, including catalogs and published information, would be useful. Since wo are conducting the evaluation for a public organization, the report on the work can be made ava Ilable on request, and appropriate arrangem ments could be made to ensure that you recoive a copy.

Wisth best megards,

George A* Jenser:

Senior Reaparth Engineer

Caramica and Polyaers Development Section

Naterlals Department

GAJ: 
Battelle

Pacific Northest Laboratories

D. O. Box 999

Richland, Washington 99352 USA

Attr. Mr. George A. Jensen

Ceramios : Polyners Dev. Sect

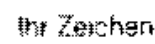

'oust ref
Ihre Nachricht wom

Yout message of
Unsus Zèichen

Ourref.

OWTt
Datum

Dats

July 12,1983

Gaseous Tritium hight Sources (GTLS)

Dear Mr. Jersen

Thank you for your letter of June 28, 1983 . Wour interest is very much appreciated. GiLSs and some devices with them are our only products, so that we are naturally interested in new applications.

We gketch answers to your questions as follows:

1. "Could industry provide a light of sufficient intensity to be useful in this application?"

To be more specitic, we would need to know from you what "sufficient intensity" wseful in this application quantitatively means.

The prototype systems you have looked at must have given you at least a good idea of what is necessary.

the further general coment refert to selfmontaned sources with tritium gas. Using a source configuration which gives a good energy conversion efficlency, any light intensity can be produced at established, known costs, the question of the hardware cost is moh more open and depends on the optical parameters required for the application and the applicable safety criteria. 
2. "What would be required to produce such a light and what would be its cost?".

Clearly, some answers to the questions raised in 1 . are necessary to give a meaningful answer to this question.

3. "Would the light be directional, bidirectional or omnidirectional?" If the application reguires, either one of these directional proporties answers in the form of economical practical designs can be found.

4. "Is there something in existing product lines which would be suitable ?"

Definitely not. Closest comes a prototype panel (usual EXIT sign size e.g. 7,5 x 16,5 inches) with an array of parabolic reflectors loaded with $5 \mathrm{~mm}$ dia green GTLSs. It is quite directional, quite rugged, weight about 5,5 lbs and its activity is some 140 Curies $\mathrm{T}_{2}$. Order of magnitute emitted light intensity is 0.25 Lumen.

5. "What are the foreseen institutional problems such as licensing, public acceptance, etc?"

In our opinion, none of the private companies handling tritium at the present time would easily increase its tritium throughput by one or two orders of magnitude, as may be necessary to support the wide scale program which you envision. on the other hand, given the proper location, expertise and capital, tritium gas in the required quantities can be handled safely.

Public acceptance may always be a problem. Here, the circumstances for acceptance should be favorable: low "physical" risk, and few exposed persons who tend to benefit rather directly.

Please, let us know, if that is the preliminary type of information you look for. Receipt of the information requested from you would permit us to become more specific.

We certainly are interested in an exchange of information and we request the report on your work when it becomes available.

I enclose a brief description on our company and some of its products.

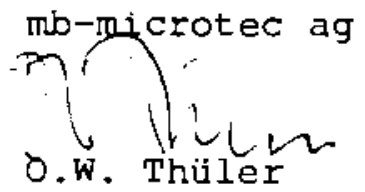




\title{
RADIUM-CHEMIE LTD. TEUFEN
}

Tolephone $071 / 3014$ is

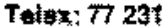

Manutachurars of Lumindus Prosiscto

and Luminising Eadipmant
Mr, Ge口rge A. Jensen

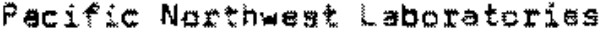

P.D. Box 999

RICHLAND, Washongton $993 \mathrm{Ez}$

U.S.A.

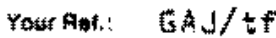

Oux Pat:

EH/h

at - ous toum

tetobe $14,19 g 3$.

Gentamats

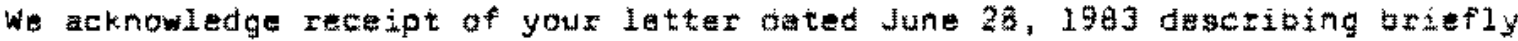

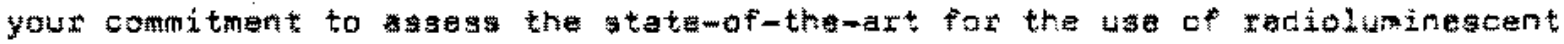

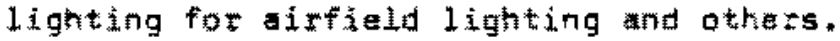

Since we are not manufacturing suctole gaseoxa tritum light aoures fow the

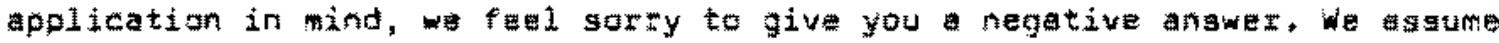

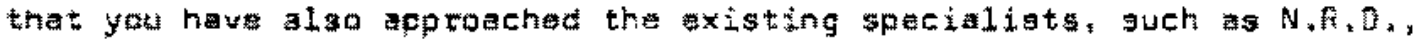
Grandhurst Co.ted. and Ma Mictotec for assistance and preposals.

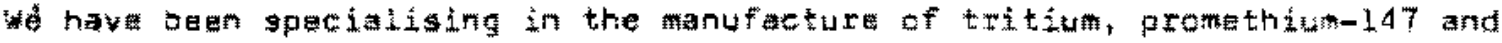

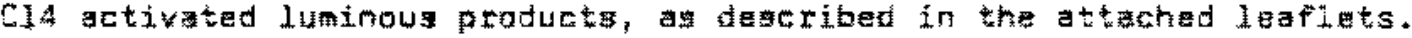

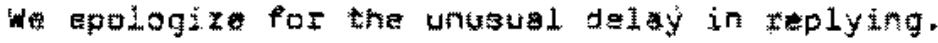

\author{
stocerety youx

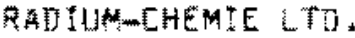 \\ \& $W W_{1}$ \\ E. Huba
}

Enes. 
$\mathrm{DAT} / \mathrm{RAB}$

6 th Iuly, 1983

Mr. G.A. Iersen,

Senior kesearch Englneer,

Ceramics Polymers Development section,

Materials bepartment:

Bat telle,

Pacifac Northwest Laboratories,

P.O. Box 999.

Richland,

Washington 99352 .

Dear Mr. Jensen,

Thank you for your letter of 28 th June regarding the use of radioluminescent lighting for airfield marking purposes.

You are quite correct in your assumption that there is a great deal of interest in this application for oux product and 3 randhurst have, in fact, manufactured several prototypes which are already undergoing trials; To answer your questions:-

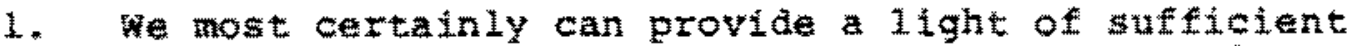
intensity to be useful in many of the applications mentioned.

2. The cost would depend upon the particular application and could vary between $\$ 50$ and $\$ 500$ per unit according to size and brightness.

3. For a given tritium content a unidirectional light would be the brightest, however, we have produced prototypes which are unidirectional, omidirectional and variable.

4. To my knowledge, there is nothing in existing product lines thich would be suitable. 
Mr. G.A. Jensen

6 th July, 1983

5. In malaland U.S.A. 1 would be necessary to licence such an object and, as it has a high tritium content, it is more Iikely to be granted a licence for military purposes.

We to not have any published information at this date but once our trials are concluded we may be in a position to forward it to you.

With best regards.

Yours sincereIy,

D. A. Tonks

Managing Director 
APPENDIX C

ANALYSIS OF AN ACCIDENT USING

DATA DEVELOPED IN REFERENCE 33 
Radiation doses from tritium are dependent upon the concentration of radioactive material released to the atmosphere, in this case tritium, and the relative amounts of tritium, as elemental tritium or water, taken up by man or animals under the same conditions of exposure. The equations used to estimate the air concentrations are not valid for distances less than about 100 meters from the point of release. For this reason, it is often necessary to rely upon data developed from animal experiments or routine handling of accidents which are a rare consequence of laboratory procedures and the research and development process. The latter case was addressed in the text. To ensure that a possible accident was not overlooked, an analysis of an accident was made using data obtained from several experiments performed using swine as an experimental an imal. (33)

The swine were contained in pens situated 0.5 meters above the location where tritium activated light sources were broken. Water content of the released tritium was high, approximately 1.5 percent, much $h i g h e r$ than that contained in any lights produced today, which is less than 0.1 percent. The experiments were conducted under two sets of conditions: first, the pens were in open air; and second, the pens were enclosed in a plastic tent-like structure to model the out-of-doors and a closed room, respectively. Tritium uptake was determined from blood samples taken prior to and 24 hours after the experiment.

The extrapolation to humans from swine depends upon the relative amount of tritium taken up by the human compared to the swine under the same conditions of exposure. Using the exposure data from these experiments as a bas is for calculation, the radiation dose to an individual in close proximity to a tritium activated runway marker ( $368 \mathrm{C} i$ of tritium) that was destroyed was 0.7 rem if the accident occured out-of-doors and 50 rem if the accident occured in an enclosed area such as a nonventilated room. The long durations of exposure and other variables in the above experiments do not permit direct comparison to the expected accidents described in the text but could define the outer limit of doses that could result from the destruction of a light. It is, of course, possible to conceive an infinite number of accident scenarios which could then be analyzed for risk. At this point, it is not clear what type of scenarios the licensing process will be required to 
consider; however, the above example shows that the probable risk to humans for an accident involving an RL lighting fixture is minimal. 
APPENDIX D

APPLICABLE REGULATORY GUIDES 


\section{- (2) \\ U.S. NUCLEAR REGULATORY COMMISSION \\ Revision 1 \\ REGULATORY \\ Auqust 1979 \\ OFFICE OF STANDARDS DEVELOPMENT}

\section{REGULATORY GUIOE 10.7 \\ GUIDE FOR THE PREPARATION OF APPLICATIONS FOR LICENSES FOR LABORATORY AND INDUSTRIAL USE OF SMALL QUANTITIES OF BYPRODUCT MATERIAL}

\section{INTAODUCTION}

This ruide describes the type of information needted by the NRC staff to evwluate an apsplication for a specific license for laboratories and industries using millicurie quantities of byprejuct material (reactor-pruduced radionuelides! This type of license is provided for under Title 10. Code of Federal Regulations. Part 30, "Rules of General Applieability to Domestic Licensing of Byproduct Mat "rial."

Fnrokraph 20.2(e) of 10 CFR Part 20, "Standards for Protection Against Hadiation," states that "...persons engaged in activities under licenses issued by the Nuclear Regulatory Coamikaion pursuant to the Atomic Energy Act of 195., as awended, and the Energy Reorganization Act of 1974 should, in addition to complying with the requirements set forth in this part. anke every reasonable effort to maintain radiation exposures, and relenses of radioactive materials in effluents to unrestricted arcas, as low as is reasonably achievable" (ALARA). Regulatory Guide 8,10. "Operating Thilowphy for Maintaining Occupational Kadiatwan Exposurea As Low As is Reasonably Achievable." provides the NRC stafr position on this important subject. License applicants should give consideration to the ALARA philosophy, as described in Regulatory Guide 8.10, in the developeent of plans for work with licensed radianctive materials.

\section{LICENSE FEES}

An apolicaticin foe is required for most types of licenes. The applicant should refer to 5170 31. "Sichedule of Fens for Materials datense:s and "hiter Kexulatory survices." of

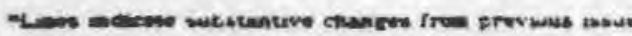
USARC MEOULATONY GUIDES

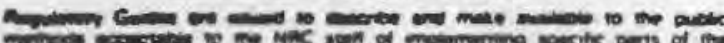

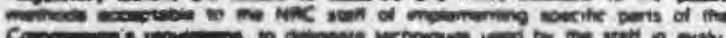

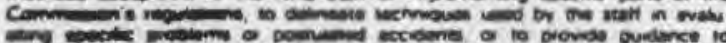

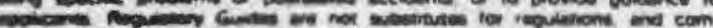

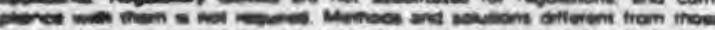

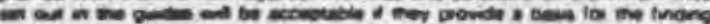

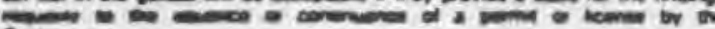
cons

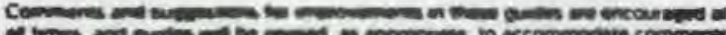

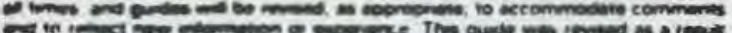

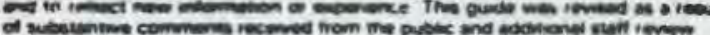

10 CFR Part 170 to determine the emount of fee that must accompany the applicution. Review of the applucation will not begin until the proper fee is recuives ty the NRC

\section{FILING AN APFLICATION}

An applicant fur a bypruduct material (radioisotopes) license should complete Furm NRC:313s (sie the appendix 4 this guide) ' All iteras on the application form should be completed in sufficient detuil for the NRC: to determine that the applicant's ectuipment, factitites, and radution protection prigram are adequate to protect health and minuaize danger to lise and property.

Since the space provided on Form NHC -313! is limited, the applicant should append additional shtets to provide complete information. Each separate sheet or document submitted with the application should be identified by a heading indicating the appropriate item number (on Form NkC-3131) and its purpose (e R. . radiation safely instructions).

The application should be completed in triplicate. The uriginal und one cupy shuuld bx mailed to the Division of Fuel Cycle and Material Safety, Uffice of Nuclear Material Safets and Safeguards, U.S. Nuclear Regulatory Commission. Washington, D.C. 20555. One ropy of the application, with all attachments, should te retained hy the applicant since the license will require, as condition. that the institution follow the statements and representations set forth in the application and any supplement to it.

IAfolicatsuns fur arches as uses should be sucantied on Furm

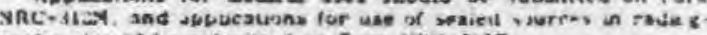
raphy sbould be subeitived on Fore XBC-313F

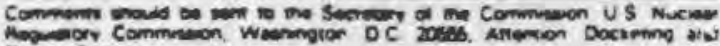
Simere Bisen

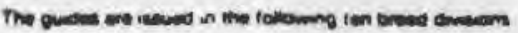

1 Poes Renctions

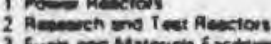

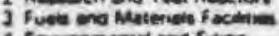

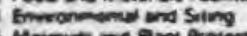
5 illoweris and Plamt Protection

6 Noweres

7 Treneocomation

- Ocosubiano toem

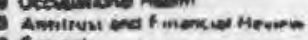
io centa

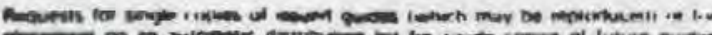

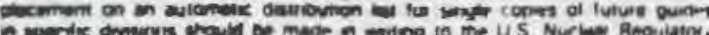

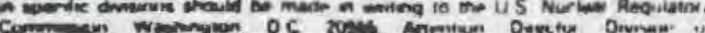

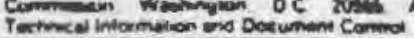

. 


\section{CONTENTS OF AN APPLICATION}

Most items of Form NHC,-313I are selfexplanatory (see instructions with the form). The following comments apply to the indicated numbered iterns of the form.

Items 2 and 4 . Specify the applicant corporation or uther legal entity liy name and address of principal office. Individuals should In. desiknated as the applicant only if the une of the byproduct material is not connected with the individual's moployment with a curtroratuh or other entity. If the applicunt is an undividual, the indovidual should $\mathrm{x}^{*}$ sperifuc ty full name and address. uniluding sfate and zip ciode

ltem 5 specify the stret audress of the ucatizs of use of the adifress differs from the une kwen in Item + . If use is to be ninite than une location. The syecific address of euch should the given. Describe the extent of use and the facilitjes and enpipment at wach incation. A post office box addrews is nul acceriatule.

Irem 6. Specify the names of the persons who will directly supervise the use of radioactive material or who will use radioactive material without supervision.

Item 7 . Specify the name of the person who *ill be designated as the radiation protection officer. 2 This person should be responsible for implementins the radiation safety program and therefort readily available to the users in case of difficulty and should be trained and experiencird in radiation protertion and in the use and handline of radiosctive materials. In a smail program not requiring a full-time radiation protection officer, the duties of the rudiation protection officer may be assigned to one of the persons named under Item 6 of Form NHa-3t3! Note, however, that it must be estatlushed that the person acting as radiation protaction officer will have the opportunity to devote sufficient time to the radiation safety aspects of the protram for the use of radiasctive materials.

Items AA, B, C, and D. Describe the byproduct material by isotope. chemical and/or physical form. and activity, in millicuries or microcuries. A separate possession limit for each nuclide should be specified. Possession limits requested should cover the total anticipated unventory, including stored meteriais and waste. and should be commensurate with the applicant's needs and facilities for safe handling.

If the use of sealed or plated suurces is contemplated. the isotope, manufacturer, and

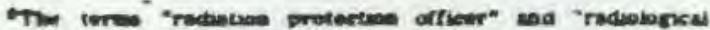

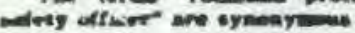

menlel number of each sealed or plated snurce: should be spectified, If a source will be used in a gas chromitogriph, gauge, or other device. the manufacturer and model number of the deviee should be specified

Item $8 E$ and Item 9. The use to be made of the radionctive materials should be clearly

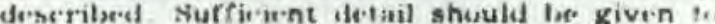
allow a determination of the putential for expme

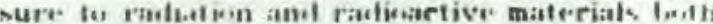
of those working with the materials anis of the fiutlin

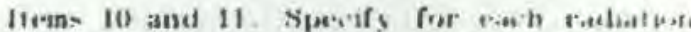

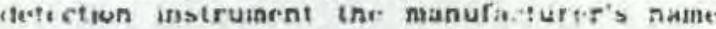
and $m$ sdel number. the numliee of weth type in instrument available, the type of radiation deterted talj,ha. Leta. Kumma, is nelutron;. the sensitivity range (millimeritgeus per hour or counts per ainute), the winde u thicknors in $m k /, m^{2}$, and the lype of use The type uf use whul.l normally he. monitnring - surveying. assuying, or mensuring.

Describe the instrument calibration procedure State the frequency, and descritue the methods and procedures for the calihration of survey and monitoring instruments, as well ab any other instruments and systems used in the radiatiun protection prugram. such as measuring instruments used to assay sealed-source lcak-test samples (see Item 15). contamination samples (e. g.. air samples, surface "wipe" samples), and bioassay samples (set Item 12)

An aderjuate calibration of survey instruments usually cannot be performed with builtin rhesik sources. Bilectrunic calitsrations that do not involve $\pi$ source of radiation are also not adequate to determine the proper functioning and response of al components of an instrument.

Daily or other frequent chreks of survey instruments should be supplemented every 6 months with a twro-point calibration on each scale of each instrument with the two points separated by at least 50 of the scale. Survey instruments should also be calibrated following repair. A survey instrument may be considered properly calitrated when the instrument readings are within $\$ 10$ percent of the calculated of known values for esch point checked. Headings within \pm 20 percent are considered acceptable if a calibration chart or graph is prepared and altached to the instrument.

If the duplicant propuses to catiturate his survey instruments, a detalled description of planned calibration procedures should be sul.mitted The description of caliuration pructdures should include, as a minimum

- The manufacturer and model number of each radiation source to be used,

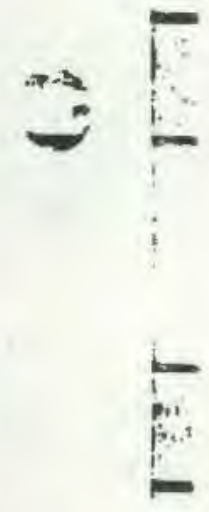


b. The nuclide and quantity of radioactive material contained in each source,

c. The accuracy of the eource(s). The traceability of the source to a primary standerd should tre provided.

d. The step-by-atep procedures. including associated rediation safety procedures, and

e. The name and pertinent experience of each persan who will perform the calibrations.

If the applicant intends to contract out the calituration of instruments, the name, address, and license number of the firm should be specified torether with the frequency of calibration. The applicant should contact the tirm that will perform the calibrations to determine if information concerming caliuration procedures has been filed with the Commission. If information concerning calibration procedures has not been filed. It should be obtained and submitted.

Quantitative measuring instruments used to monitor the adequacy of containment and contamination control such as those used for measuring leak test, wir, efrluent, bioussay, work area, and equipment contamination samples should usually be calibrated prior to each use. The procedures and frequency for calibration of such instruments should be submitted and should include:

a. The name of the manufacturer and model number of each uf the standards to be used.

b The nuclide and quantity of radioactive material contained in each of the standard suurces.

c. A statement of the accuracy of each of the standard sources. The source eccuracy should be. as a minimus. Is percent of the stated vilue and traceable to a primary standard. surh an that mainsained by the National Bureau of Standards.

d Step-by-biep calibration procedures and. if apjaopriate. wanociated radiation safety procosdures and

- The nase and pertintent experienct of enech jersom whw will perform the instruasent caluratwas.

Item 12. Persunnel monituring is required to ensure cumpliante with $\$ \$ 20,101$ and 20.202 of 10 CFR Part 20. Personnel monitorung is also recuugred if a jerson enters a high radiation area (greater than 100 willirems per hour). If (m-rwnmel awnituring cquipment will be used, the name of the organization furnishing film badge or thermuluminescent dosimeter (TLD) servic and the frequency for changing badges. dosibeters, etc. , should be specified. If pocket chambers or pocket dosimeters will be uned. the useful range of the device. in milliroentgens, the frequency of reading, and the procedures for maintaining and caljurating the devices should be specified

If personnel monitoring will not be usell, the applicant should submit calculations or dueumentation from radiation surveys demonstrating that it is unlikely that any individual wil! receive a dose equal to or Ereater than that indicsted in 10 C.F $\mathrm{P}$ Part 20

The applictint should show that the netef fut bionssays has been thoroughly cunsiderud ar.d should establish the artequacy of the proposted biuissay prigram in relation to the protyista program of use of radiosctive material. Bioassays are normally required wher indivduals work with millicurie quantities of hydrugen-3, jodine-125, or jodine-131 defiending on the type of work. equipment, and procedures folluwed. Regulatory Guide 8.20. "Applications of Birsassay for $I-125$ and $I-13]$," and a document entitled "Guidelines for Bioassay Requirements for Tritium"a may be consulted. Other matterials may ulso be used in physical or chemical forms and under conditions that present an opportunity for uptake by the body through ingestion, inhalation, or absorption. A bioassay program to determine and control the uptake of radioactive material should be considered and discussed in relation to each such material. provedure, fir. liegulitory Giuile 8.9. "Accieptable Concepts, Models. Equations. and Assumptions for a Hioassay Program." may be consulted.

The criterid to be used in determining the need for bioassays, the type and frequency of bioassays that will be performed, and the bioassay prosedures should be specifiesl and described in detail. If a commercial biuassay service is to be used. the name and address of the firm should be provided.

Bioessays may not be substituted for other elemenis of a safely program such as air monitoring and dispersion control (hoods, glove boxes. ete, and for well-thought-out and well-executed handing procedures

ttem 13. The fucilities and rquipment for each site of use should te deserilsed in detail The pruposed facilities and equipment for each eperation la be crinducted should tre adeciuats. to protect health and minimize danger to iffe and properiy. In describing avalable facilities and equipment. the following shuuld beineluded. as appropriate:

a. Physical plant. Iatroratury, or nurking area facilities Fume hoods, glove thixes, waste. receptackes, spetcial sinks, ventulation antl comtainment systems, effluent futer systems, and

IA sopy say be obtauned by a Entten request to the U 5

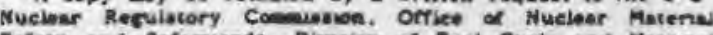
Saltery and Salepuards. Divnsion of Fuet Cyele and Materna Salety, Wouningon. D.C. 20sss, Attencion Director, Office of Nucleser Maternal Sarety and Salocuneds. 
all processing. work. and protective cluthink change areas should be described.

A drawing or sketch shuuld be submitted showing the location of all such equipment and the relationship of areas where radionctive matcrials will be handled to unrestricted areas where radioactive materials will nut be handled In those programs where radioactuve material may become airborne or may be included in airborne effluenls, the drawing or sketch should also include a schematic description of the ventilation system annotated to show airflow rates. dirferential pressures. filtration and other efnueat treatment equipment. and air and efnuent monitoring instruments. Drawings or skelches should be drawn to a specified scale. or dimensions should be included on each drawing or sketch. Each drawing or sketch should be labeled to specify the location of the facilities and equipment depicted with respect to the address(es) given in Item 5 of Form NHC-313I.

b. Containers. devices, protective clothing, auxiliary shielding, ceneral laboratory equipment, air sampling equipment, etc. . actually employed in the daily use of material. Special provisions for shielding and containment to ainimize personnel exposure should be described. Storage containers and facilities should provide both shielding and security for materials.

c. The number, type, and length of rewote huadling devices.

d. If respiratory protective equipment will be used to limit the inhalation of airborne radioactive material, the provisions of $\mathbf{5 2 0 . 1 0 3}$ of 10 CFR Part 20 should be followed and approprate information should be submitted.

Itcm 17. The procedures for disposing of byproduct material waste should be described. Under NhC regulations, a licenset mey dispose of waste in the following ways:

a. Transfer to a person pruperiy licensed to receive such wuste in conformance with parragraph $20.301(a)$ of 10 CFK Part 20. The name of the firm (which should be contacted in udvance to determine any limitations that the firm may have un acceptance of waste) should be given.

b. Release into a sanutary sewer in conformance with 520.303 of 10 CFR Part 20. Depending on water usage, releases of up to 1 curie per year are permitted.

c. Burial in soil in conformance with $\$ 20.304$ of 10 CFR Part 20. Up to 12 burials per year are permisaible. The allowable quantity depends upon the radionuclide.

d. Helease into air or water in concentrations in conformance with $\$ 20,106$ of 10 CFR Part 20 Pussible exposure 16 jersens uffsite limits the amount that may be releused.

c. Truatment or dasposal by incincretion in conformanes with $\$ 20305$ of 10 CFH Part 26 This mutt be specificully approved by the Cramixsion

f. Other methnd: aprecifirally afyroved by the Commissirn pursuatal to 520302 of 10 CF K Part an

\section{Item 15}

a. Survey Program. Commissiun regulations require that surveys be made to determine if radiation hazards exist in a facility in which radionctive materials are used or stured (see 520.201 of 10 CFR Part 20). A survey should include the evaluation of external exposure to personnel. concentrations of airborne radioactive material in the facility, and radioactive effluents from the facility. Although a theoretical calculation is often used to demonstrate compliance with regulations rexarding airtorne or external radiation, it cannot always be used in lieu of a physical survey.

Except for those cases where sources of rudiation and radioactive material are wel known and arcurately and precisely contrulled. it will usually be necessary that a physical survey be made with appropriate detection ind measurement instruments to determine the nature and extent of radiation and radioactive material or, as a minimum, confirm the results of a theoretical determination.

A radiation prulection program shuuld include the following surveys fur radioactive contamination and radiation.

(1) In laboratory or plant areas (ค.g. checking for contamination on bench tops, handling and storage equipment. (iathing. hands).

(2) White nurk is being Jone with radialon or radioactive materials (e.g.. breathing zone air surviys, general air surveys: personnel exposure measurnments, including eyes and "xtromitien: shecking shutters and containment).

(3) In areas associated with disposal or release of radioactive materials (e, g.., checking

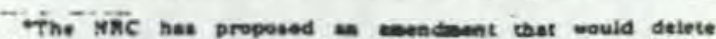

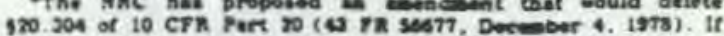

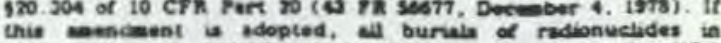
secordasee with 120 . 04 of $10 \mathrm{Cr} / \mathrm{h}$ Part 20 mill require NhC approvel. 
disposal containers and disposal sites: liquid, cas, and solid efrluents; filters and filter-duct isstems).

The frequency of surveys will depend on the nuture of the rudioactive asterials anit their use. However, surveys should be performed prior to the use of radionstive materials in order to establish a baseline. The surveys should be repeated when radioactive materials are present, when the quantity or type of material present changes, or when changes occur in their containment systems or methods of use. Repetitive surveys may also be necessary to control the location of radioactive materials in the handling system and in the case of the use of sealed sources outside a shieided container.

For operations involving materials in gas. liquid, or finely divided forms, the survey program should be designed to monitor the adequacy of containment and control of the materials involved. The program should include air sampling, monitoring of effluents, and survey. 10 evaluate contamination of personnel, facilities, and equiponent, Physical effluent messurements are essential to determine compliance with Appendix B to 10 CFR Part 20.

The description of an air sampling program should include the area where samples will be taken, the frequency of sampling, and the location of the sampler with respect to workers' breathing zones. Aasays performed to evaluate air samples and the methods used to relate results to actual personnel exposures should alsu be deseribed.

The effluent monitoring prokram for releases to unrestricted areas should encompass all airborne and liquid radioactise material releases. Theoretical evaluations should be supplemented by stack monitoring, water sampling. and other environmental monitoring apimopriate for the planned and potential releoses.

For operations involving only sealed buurces. a survey progran should include *vaiustion and/or measurement of radiation lavels for storage and use configurations. When murces are used in devices having "on" and " "ff" pusitions, buth positions shuold be evalwated at the time of installation. Supplemental surveys should be performed following any changes in operation, shielding, or use.

The types. methods, and frequency of surveys should be described in the application. Guidance may be obtained from the National Council on Radiation Protection Report No. 10. "Radiological Monitoring Methods and Instruments, ${ }^{\circ 5}$ and the International Atomic Energy

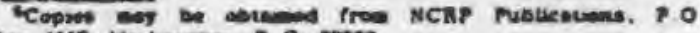

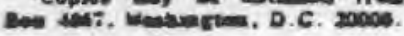

Agency's Technical Report Series No. 120. "Monitaring of Radiosctive Contamination on Surfaces."

b. Recurds Management Program. Provision for kerping and revicwing records of surveys; materials inventories: persunnel exposures: reveipt, use, and disponsal of materials, etc.. should be described. Persons responsible for hceping and reviewing records should be identified

c. Sesled-Source Leak-Test Procedures Sealed sources containing more than 100 microcuries of a beta or gamma emitter or more than 10 microcuries of an elpha emitter must be leak tested at 6-month intervals. Leak testing of alpha-particle-emitting sources containing mort than 10 microcuries of an alpha emitter is required at 3 -month intervals. If a commercial firm is to perform the leak tests, the name, address, and license number of the firm should be submitted. If the tests are to he performed using a commercial "kit," the name of the kut manufacturer or distributor and the kit model designation should be given. If the applicant intends to perform his own leak tests without the use of a commercial kit, the following information should be submitted

(1) Qualifications of personnel who will perform the leak test.

(2) Procedures and anterials to be used in taking test samples.

(3) The type, manufacturer's naree. aodel number, and radiation delection and measure. ment characteristics of the instrument to be used for assay of test siamples.

(4) Instrument calibration procedures. including calibration source charactoristics. make, and model number, and

(5) The method, including a sample calculation. to bi. used to convert instrument readings to units of activity, e.g... microcuries.

d. Instructions to Personnel. If a numter of indisiduals will use radioactive materials under the supervisusn of one or more of thise persons named in Item 6 of Fora NIRC-3IJI. written instructions should be prepared and sulemitted with the license application in the form in which they will be distributed to those working with radioactive materiais. These instructions should cover, but not necessarily be limited to:

(1) The availability, selection, and use of laboratory apparel and safety-related equipment and devices (e.g.). laboratory coats, gloves, and remote pipetting devices).

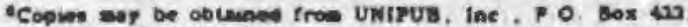
Nes York. IX Y 10014 
(2) Limitations and conditions to be mets in handling liquid or uncuntained (unencapsulated. dispersible. or volatile) radioatlive materials and special lakoratory equipment to be used in working with these types of matcrials. For example, the instructions should explain when operations with materials should be confined to a radiochemical fume hood or glove bos and should specify the use of appropriate shielding and remote handling equipment when energetic beta- or gamma-umitting matcriais are to be used.

(3) The performance of radiation survey and monitoring prucedures for each rea in which radioactive materials are to be used.

(4) Safety precautions to be observed in the movement of radioactive materials between buildings, rooms, and areas within rooms.

(5) Safety requirements for storage of radioactive materials, including labeling of containers of radiosctive materials and posting and securing areas where radionctive materials are to be stored. This should include the storse of contaminated laboratory equipment such as glassware.

(6) Requirements for posting of areas in which radioactive materials are used.

(7) The availability and use of personnti monitoring aevices, including the retording of radiation expusures and the procedures $t w$ be fullowed for the processing of personnel monitoring devices such as theimoluminescent dosiweters and film badges in order to obtain personnel muniloring results.

(8) Waste dispusal procedures to be followed. including limitations on the disposal of licuid or other dispersible waste to the sanitary sewer and procidures for the collertion. - torage, and disposal of uther wastes.

(9) The maintenance of appropriate records as required by $10 \mathrm{CFR}$ Part 20 and 10 CFR Part 30.

(10) The requirements for and the method of performing or having spproprinte sealedsource leak lests performed.

(11) Good ractiation safety practices, including the control of contamination, specificauon of acceptable remoovable and fixed contamination levela for both restricted and unrestricted areas, prohibition of smoking and the cansumption of food or beverages in areas where radionctive materials may be used, and prohibition of the frequent transter of potenlially contaminated equipment between potentially contaminated areas and unrestricted areas.
(12) The use of radiractive matrerials in animils, If radioactive materinis will be: usert in animits, instruetions cuncrerninx sus:h use shouid te prepared and submitted with the lisense application. Such instructions should include (A) specification of the facilities to be used to house the animals. (b) instructicins to te provided to animal caretakers for handling animais, aninal wastes, and carcasses, (c.) instructions to appropriate personnel for cleining and decuntaminating animal cages, wnit (d) methods to be used to ensure that animal moms will the low:ked or otherwise securoul unio-ss attended by authorized users of radioactive maturials, A description of animal handling unct housing facilities should be included under Item 13 of Form NRC-3131

(13) Eroergency procedures. These instructions should be addressed to all persons in all latuoratory or facility areas where radioactive materials will be used and should cover actions to be taken in case of such accidents involving radioactive materials as spills, fires, release or loss of material, or accidental contamination of personnel. Specifically, these instructiuns should (a) specify immediate actions to be taken in order to prevent or limit the contamination of personnel and areas. e.g. . the shutting down of ventilation equipment, evacuation of contaminated and potentially contaminated areas. containment of any spills of radinactive material, (b) give the telephone numbers of individuals to be notified in case of emergency. and (c) instruct personnel in proper entry. decontamination, and recnvery operations for contamunated facilities. (Nole: Only properly trained indisiduals should attempt decontamination and recovery operations.)

(14) Requirements and procedures for picking up. receiving, and opening packages (see $\$ 20.205$ o( 10 CFR Part 20)

ttems 16 and 17. A resume of the training and experience of each person who will directly supervise the use of material, who will use material without supervision, or who will have responsibilities for radiological safety should be submitted. The resume should include the type (on-the-job or formal course work), location, and duration of the training. Training should cover (a) principles and practices of radiation protection, (b) radioactivity measurementa, standardization, and monitoring techniques and instruments, (c) matheratics and caiculations basic to the use and measurement of radioactivity, and (d) biologrical effects of radiation. The description of the use of radioactive materials should include the specific isotopes handled, the maximum quantities of materials handled, where the experience was gained, the duration of experience, and the type of use. The qualifications, training, and

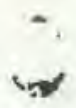
- 
experience of pach persem shesulit toe trummien:eurute with the material and its uae as porogrised or. the application. The amiunt and tyin wif training and texperience with idslistion snd ridioactive materials reyuired tox suppurt a determination of adequacy by the Commissiun will vary markedly with certain fucturs.

If other persons such as tcchnical askistants and laboratary uorkers will use radiuactivi materials in the ubsence of persons spereifited atruve, the sperification of the training of such personnel should include (a) instruction in radiation cafety. including topics covered and by whom taught. (b) on-the-job training in use of rediosctive materials, and (c) determination of competency to work without the presence of supervisory personnel.

The use of microcurie quantities of a few nonvolatile radiosctive materials by a person with a minimum of training and experience under precisely specified and carefully contrisled condition. subject to the surveillance of a conpetent and adequately traine-d radiatiun protection officer may be justified. Such minimum training and experience mey consist of a few hours of training and experience in the use of one or more radioactive matcrials similar fo the use proposed in the application under the supervibion and tutorship of $*$ licensed user

Persons using millicurie quantities of a number of radiunuclides for general laboratory tracer work under unsptcified conditions shuuld have more extensive trafning and experience and, depending on the exact nature of the proposed program of use of radionuclides. may need to have completed formal tourse. whrk at the college or university level cuverink the areas lasted under ftem 16 of Form NRC-313t

The use of Larger quantities of material (ajproaching a curie) under conditions where a pilential exists for significant loss and ingestion, inhalation, or absorption of the radioactive material by those working with the material is norzally done under carefully controlled conditions using specialized equipment. A person who is to use radioactive materials independenaly under these conditions should not

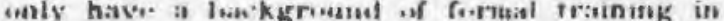

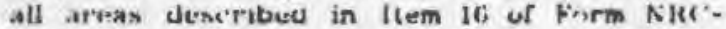
atist biat shusla als. have exiensive expreterence working with radractuve material and * thorough working knowledge of the equipment required to handle the material safely

\section{AMENDMENTS TO LICENSES}

ticenaces are rectuired to enduct their pres krams in wicordance with statements. repre. sentations. and procedures contained in the License application and supportive documents. The license must therefore be amended if the licensee plans to make any changes in facilities, equipment (including monitoring and survey instruments), procedures, personnel, or hyproduct material to be used.

Applications for license amendments may be filed either on the application form or in letter form. The application should identify the license by number and should clearly describe the exakt nature of the changes, additions. or deletions. References to previously sulmitted information and documents should be clear and specific and should identify the pertincent intormation thy date, patge, and paragriagh

\section{6. renewal of A License}

An applicatun for renewa! of a license shoul: be fil.d at least 30 days prior to the expiration date. This will ensure that the license dta.s not expire untic fond action on the application bas heen taken by the NAC as provided for in waragraph $30.37(L)$ of 10 CFR Part 30.

Henewal applications should be filed on fiurm NBe:-3I:H. appropriately supplemented, anit should cuntain complete and up-to-date informatjon about the applicant's current program

In urder to focilitate the review process. the applisation for renewal should be submitted without reference to previously submitted documents and information. If such references cannot be avoided. they should be clear and specific and should identify the pertinent information by date, page, and paragraph

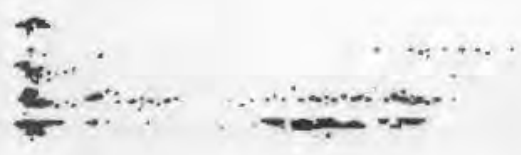


APPENDIX A

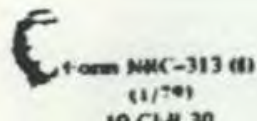

$10 \mathrm{Cr} 430$

U.S. NUCLEAR AEGULATORY COMMISSION

Inem Aprewered hy Q.A4) H inaz2s(kessiy)

\section{INSTRUCTIONS FOR PREPARATION OF APPLICATION FOR BYPRODUCT MATERIAL LICENSE}

FORM NRC-313 (1)

GENERAL INFOAMATION

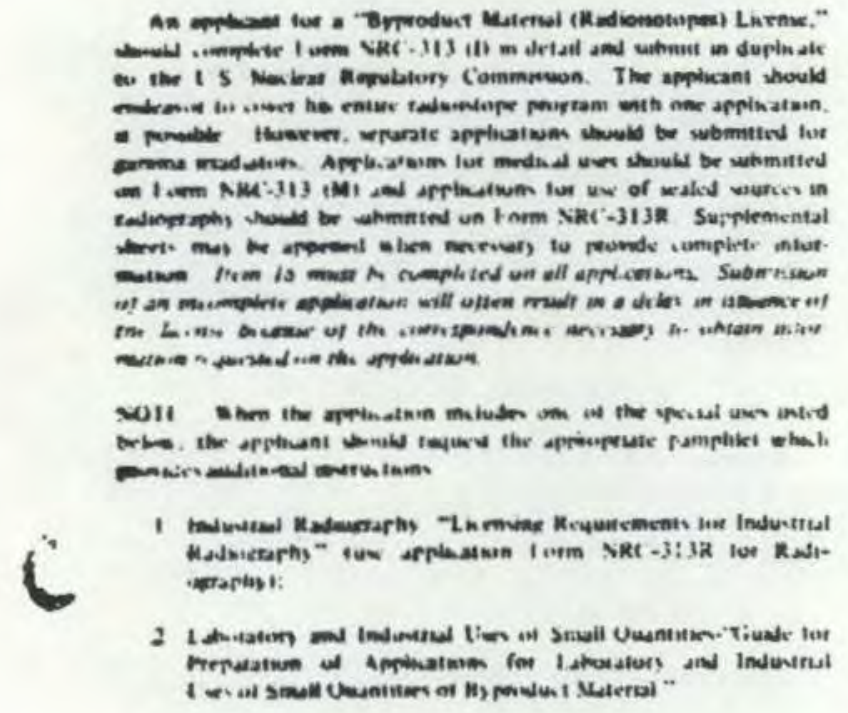

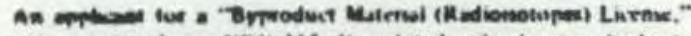

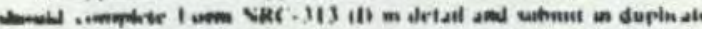

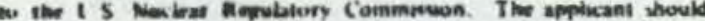

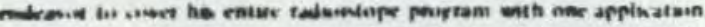

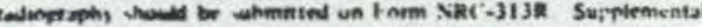

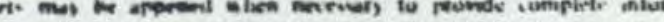

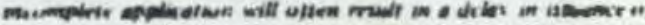

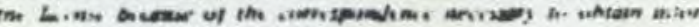

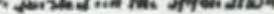

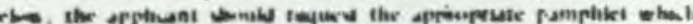

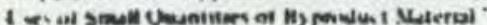

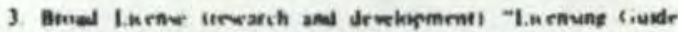

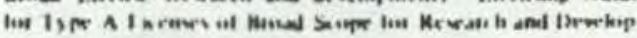
ment:

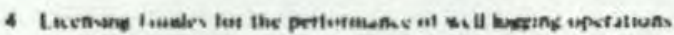

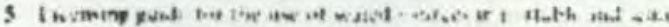

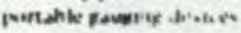

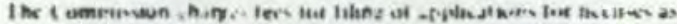

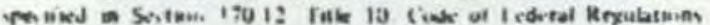

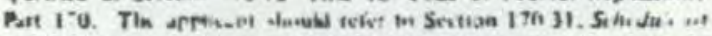

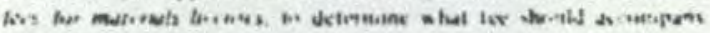

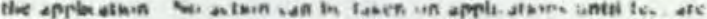

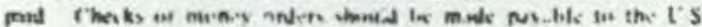

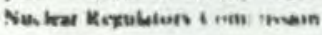

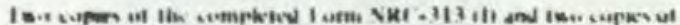

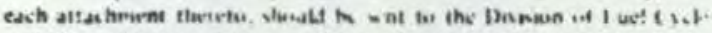

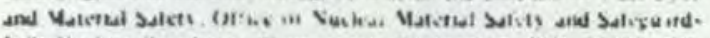

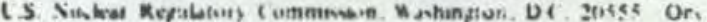

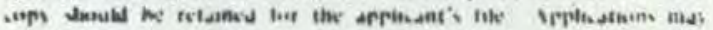

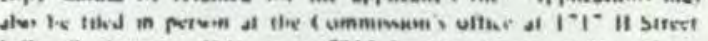

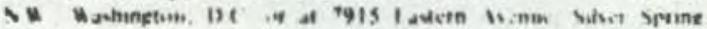
Waribend 


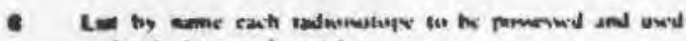

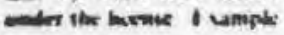

\section{A}

116 1.4. $10 x-131$

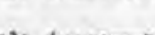

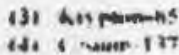

(4)

11. S.4 imsucolth

Li: $1 \mathrm{~A}$

a. 3 :

(4) INi i.ep

Gindsel $8-78$
(11) Dowales

121 Dedinderd thunater

S-aren. IWranten

131 cess

ad > ind mithe.

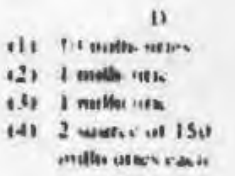

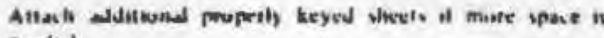
mriked

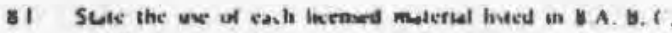
And 0

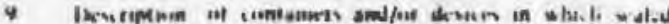

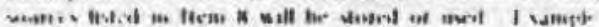

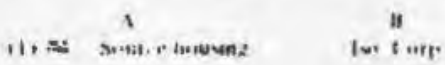$$
\text { , }
$$

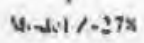

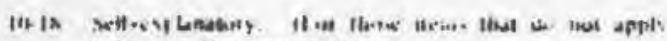

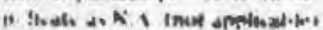

\section{PaivaCy act statement}

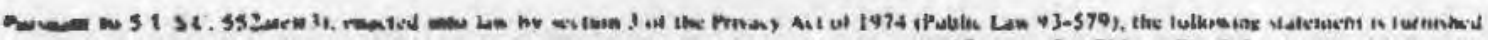

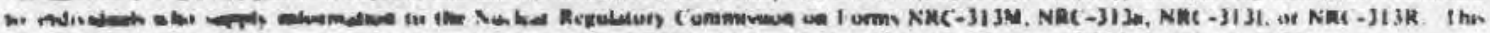

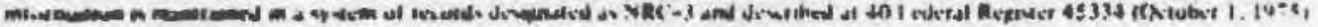

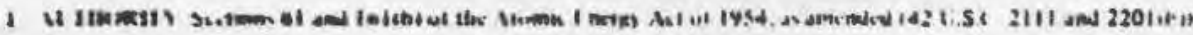

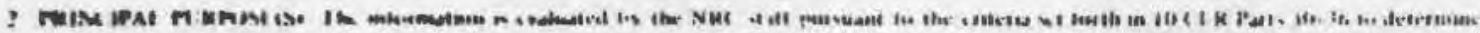

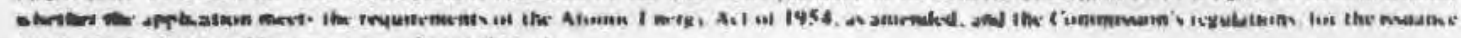

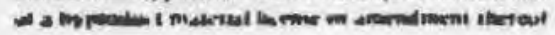

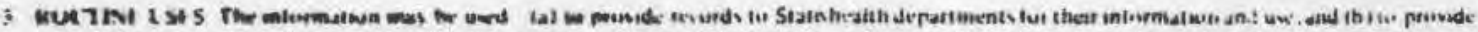

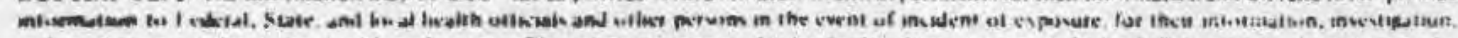

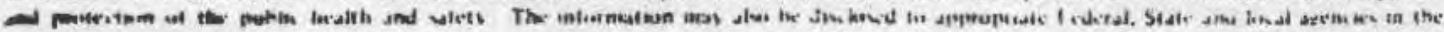

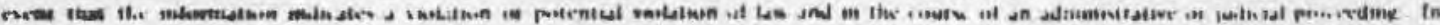

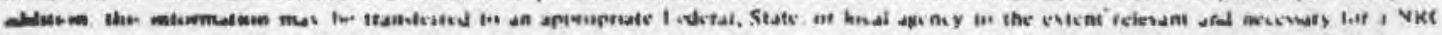

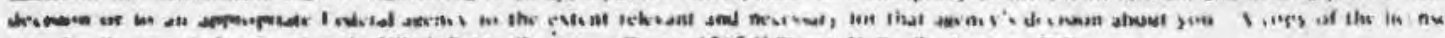

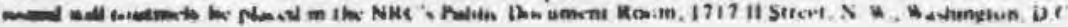

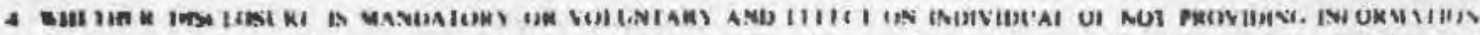

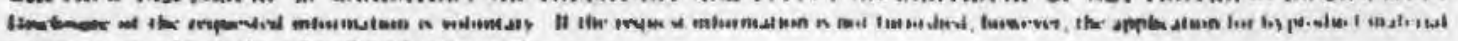

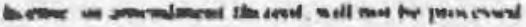

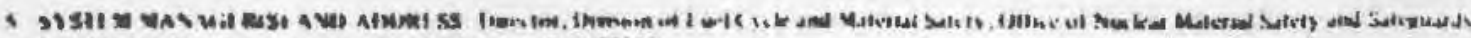

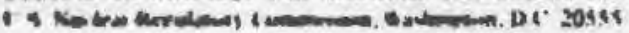

2.

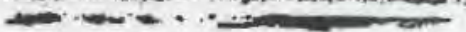

-

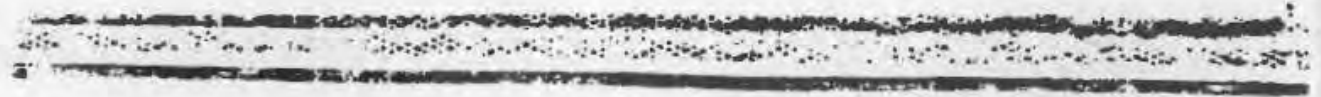




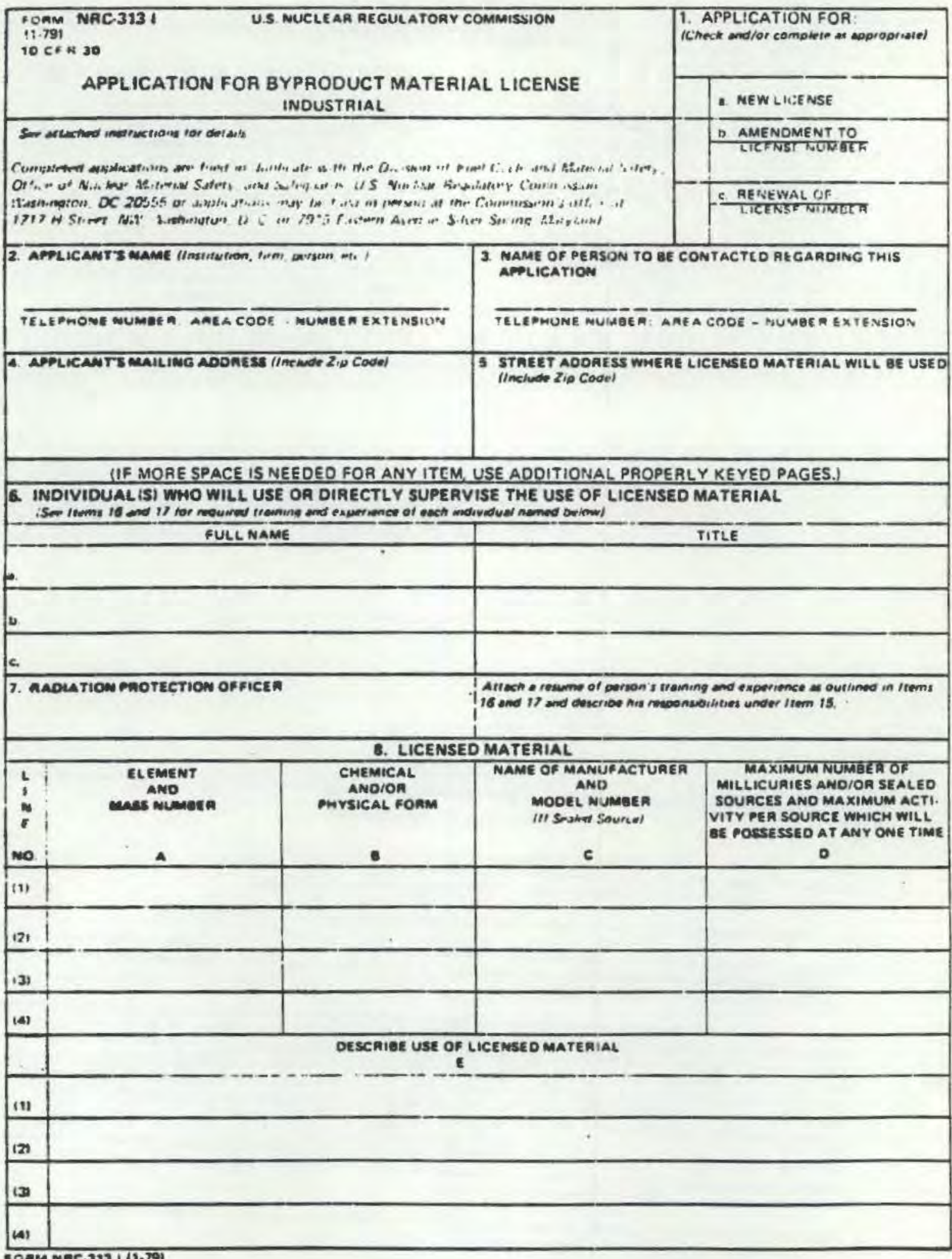

10. $7-11$

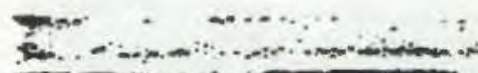




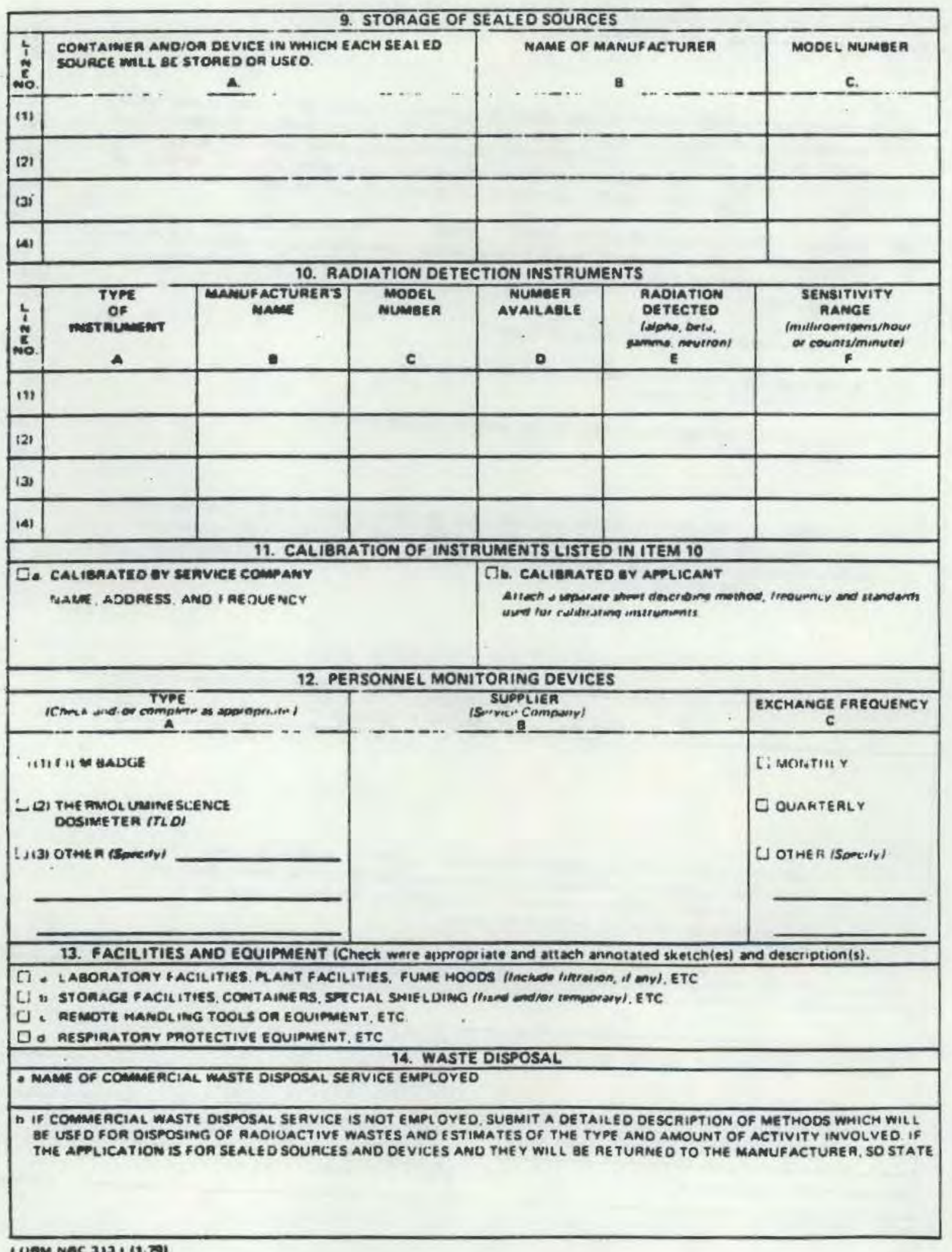

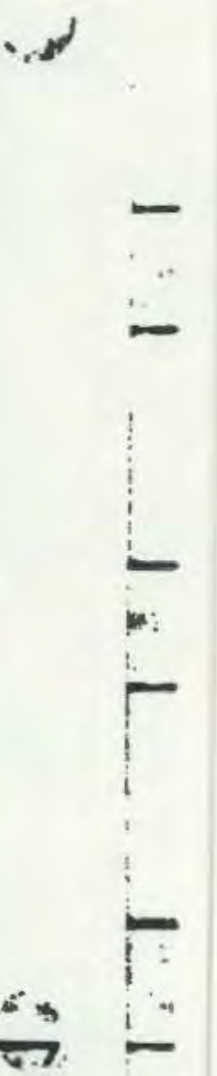

I OAM NAC 313 I (1. A)

$10.7-12$ 
15. RADIATION PROTECTION PROGRAM. Describe the radiation protection program as appropriate for the material to be used including the dutien and responsibilities of the Rediation Protection Officer,

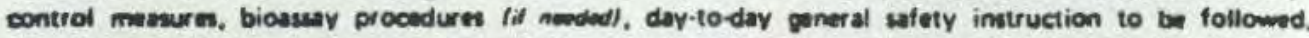
vec. If the application is for saled source's also submit leak testing procedures, or if leak terting will be performed using s lenk test kit, specify menufacture and model number of the leak tent kit.

16. FORMAL TRAINING IN RADIATION SAFETY. Atrach o resum for each individual named in Items 6 and 7. Describe individual's formal training in the following arean where applieable. Indude the name of person or inatitution providing the training, duration of training, when training wa recaived, etc.

a. Principles and prections of radiention protection.

b. Radiouctivity menurement standardization and monitoring techiniques and instrumens.

c. Mathometies and caleulations besic to the use and mossurement of radiosctivity.

d. Biolopical eftects of radietion.

17. EXPERIENCE. Attach a resume foe eech individual nomed in llams 6 and 7. Describe individual's work experience with redistion, ineluding where experience was obtained. Work experience of on the-job training should be commensurate with the proposed use. Incluale list of radioisotoper and maximum activity of each uned.

\section{CERTIFICATE}

IThe inem must be comoloted by evoucant

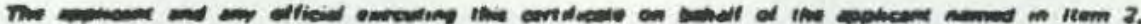

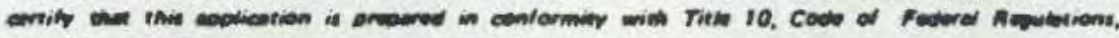

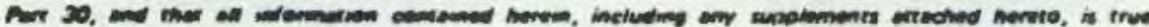

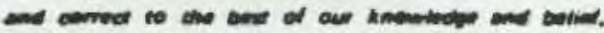

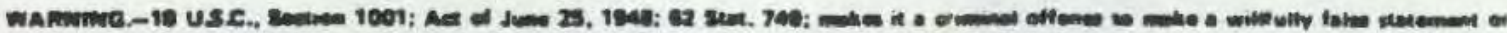

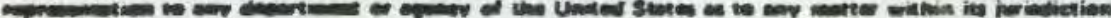

\begin{tabular}{|c|c|}
\hline \multirow[t]{2}{*}{ 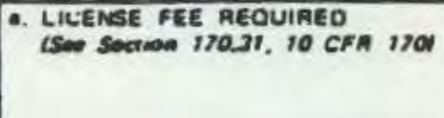 } & b. CERTIFYING OEFICIAL ISISneturel \\
\hline & c. NAMAE ITrope or orienel \\
\hline (1) LICENSE FEE CATECOAY: & d. TITLE \\
\hline (2) LICENSE FEt $z$ NuCLOSED: $s$ & 6. DATE \\
\hline
\end{tabular}

FOn NAC-312 I (1.79) 


\title{
CUSTOU MADE SEALED SOURCES AND DEVICES
}

\author{
GUIDE FOR STANOARD FDRMAT AHD CONTENT \\ OF APPLICATIONS FOR HEALTH AND SAFETY \\ REYIEHS OF CUSTOM MADE SEALED SOURCES WD \\ DEYICES CONTAINIHG LICENSED RADIOACTIVE HATERIAL
}

1 PURPOSE AND SCOPE

This gufde provides a description of the content and format of an applitation for the possession and use of custom made sealed sources and/or devices by an applicant specifically licensed pursuant to 30.32, Title 10 Code of Federal Regulations. Part 30. Use of this format will ensure the completeness of the information needed for the eustom review and will aid in shortening the time required for the revtew process.

II CONTENT OF APPLICATIOH FOR CUSTOM REYIEN AND LICENSIHE OF SEALED SOURCES AMD DEVICES

The applicant shall submit sufflctent information regarding aach model of sealed source and/or devlce to enable the NRC to make a safety analysis of the sealed source andor device fncluding safety and efficacy of the proposed use. Such information shall include:

1. Identification

A. Selled, plated or folt radloactive sourcelsl.

(1) If the radioactive source design is reglstered with the NRC or an Agreenent State, spectify the manufacturer. nodel number, 1 sotope and maxinum activity for each source to be incorporated into the device.

(2) If the sealed source design has not been registered with the NRC or an Agreement State, provide the information as outlined in Appendix A for the custom sourcel $s)$.

B. Device

(1) Specify the nane and address of the manufacturer.

(2) Identify the device by type or descriptive name and model number or other specific model designation. 
2. Proposed Use

A. Describe the proposed use of the device and identify the enviroments and operating conditions expected during normal conditions of use. Include descriptions of the types of users, locations of use and the circumstances of normal use.

B. Describe the probable effects of severe conditions on the device, including accidents and fires, and possible diversion fran intended use.

3. Construction

A. Submit engineering drawings of the source housing, identifying

all materials of construction, dimenstons, methods of fabrication and means of incorporating the radioactive material into the source housing and device.

B. Include a detalted description of all special design

features (for example, shutters, fail safe onm off mechanism. (nterlocks, etc.) wich protect the radioactive naterial frow abuse and mintizize the radiation hazards. Describe in sufficlent detail so that the nature, function and method of operation are clearly defined.

NoTE: If device is foreign made, all drawings, notes, descriptions etc. shall be in English.

4. Human kccess

Describe the degree of access of human beings to the radioactive araterial contained in the device and to the radiation emitted from the device during normal condtions of use.

\section{Radation Proflles}

Provide calculations, ostimates or neasurements where avallable of the radiation profllys, e.g., expected dose rates at $5 \mathrm{~cm}$, $30 \mathrm{~cm}$ and $100 \mathrm{~cm}$, from the nost and least accessable surface of the custom device with the shutter(s), on-off mechanism(s), etc. In (1) the open or "on" and (2) closed or "of $f^{*}$ posithons. These radiation profiles should be provited for each kind of radfoactive material and naximum activity expected to be used in the device. 
6. Labeling and Instructions for Use

Submit facsimilies of the labeling or marking to be placed on the device. Include a description of where the device wll1 be labeled. The label or marting shall consist of the name, trademark, or symbol of the manufacturer, assembler, or the licensee who will possess the custom device, the type and atount of radioactive material. the date of measument, the standard radiation symbol and the words, "CAUTION RADIOACTIVE MATERIAL." The label or marking must be of the standard radiation caution colors as spectitied in $\$ 20.203,10 \mathrm{CF} 20$.

\section{Avallabllity of Services}

Submit information stating who will perform the following services on the custon device. (If any of the listed services will be performed by someone other than the specifically Ifcensed device manufacturer, provide a descriotion of training and experience of the individual(s) who will perform the services and include description of the procedures to be used in the performance of the services.)

A. Installation and relocation within the applicants facilities. If applicable.

B. Initial radiation survey upon receipt. installation, etc. at the applicant's factitity.

c. Leak Testing: (Required for all sealed sources other than gaseous, e*g. krypton-85, or sources with halflives of less than 30 days.) A certificate showing that each radiation source contained in the device has been tested for lisakage or contamination with $\$$ ix (6) months of the date of transfer to the recipient of the devfte must be provided to the reclpient. Results of the leak testing shatl be in units of microcurles and should be matntsined by the licensed recipient for inspection by the comission. State if the device manufacturer will furnish the leak test certiflctite on the finished device or, otherwise, fully explain the mesns of obtaining the initial leak test certificate.

0. Repair, periodic maintenance, shutter or beam control operations checks.

E. Source exchange. 
F. Disposal in the event the custom gevice is no longer nesded.

8. Test Results on the Finished Custom Device Frior to Use

The apolicant shall speclfy that the tests listed below wll be performed on the finished custom device to verify that the device meets speciffcations furnf shed to the kat. If the test results are to be supplied to the reclpient by the lifensed device manufacturer, it should be so stated. If the specified tests are not to be conducted by the specifically licensed device manufacturer, the applicant shall specify the name(s), training and experlence of the person(s) whe will perform the tests; and a description of the procedures and equfpment to tie used for performing the tests shall be included. coples of the test results on the custon device shall be maintained for inspection by the conmisston.

A. Radiation proftles (Isodose curves, for example, cose rates at $5 \mathrm{~cm}, 30 \mathrm{~cm}$, and $100 \mathrm{~cm}$. l of the custon device with shutter(s) and/or bean control mechanism(s) in both the (1) open ("on") and (2) closed ("off") posttions. Radiation levels should be neasured using the maximum activity of each kind of radioactive materlal tc be used in the device.

8. Yisual or other quality control inspections to determine If cracks, volds, or other nanufacturing defects exist.

C. Shutter or other "ON"-" "OFF" beam control operations.

0. Leak tests for radiation leakage or contanination prior to use.

E. Other Tests: Specify any additional tests to be done on the finished custon device to verlfy that the device can be operatad safety wh minimum radiation hazard.

9. Safety Analysís Summary

Submit arlef safecy anlaysis 5 ummary on the evaluation of the ablity of the custor design to withstand the nomal conditions of handing, use, and storage: iacluding corrosion, vibration, impact, and the probable effects on radiation containant and shielding of abnormally severe conditions, such ss explosion and fire. Any addtional information including results of experimental studies and tests which will facilitate the final determination of the safety of the custom device should al so be included in the safety analysis samary. 
APPENDIX A

CUSTOM MADE RADIATION SOURCE(S)

A. Custon Source Supplier

Identify by name and address the supplier of the custom made source to be used in the custom made device.

B. Identification

Identify the source by type or model number or other specific model or part number designation.

C. Radjoactive Material

(1) Specify the radioisotope.

(2) Maximum activity per source in millicuries or microcurles.

(3) Chemical and physical form of the radioactive material.

(4) Descriptive detaits of the method of incorporating and binding the radioactive material in the source.

D. Construction

(1) Submit engineering drawings of the source capsule (both inner and outer capsule, if applicable) identifying all materials of construction, dimensions and methods of sealing the source.

(2) Submit drawings of the source hoider, for example, the mechanical support for the source, if any, fdentifying materials of construction, dimensions and methods for mounting the source in the holder.

NOTE: If sealed source is forefgn made all drawings, notes, descriptions, etc. shall be in English.

E. Labeling

Provide a description of the information to be engraved, etched or imprinted on the radiation source or a facsimile of the label containing this information to be attached to the source. Ideally the source labeling should include the words: "CALT?DH - RADIOACTIVE MATERIAL," manufacturer's trademark or unique serial number, radionuclide activity, assay date, and the radiation symbol. Where labeing the 
source is impractical, a tag containing the above information should be attached to the source, uniess the attachment of such a tag is also inpractical. NoTE: When a sealed source is permanently mounted in a device, source labeling is not reguited provided the device is labeled as spectified above.

F. Source Assay

Deseribe the sssay method used to determine the radjosctive content of the finished source. The assay method shall be traceable to a National Standard.

G. Quality Control Inspections of Finlshed Source

Describe the tests to be performed on the finished source to ensure

- that the final product neets the design specifications. Where applicable provide information on the following minimal tests.

(1) Visual or other inspections to performed on source seals or welds to ensure Integrity of the finished product.

(2) Leak tests.

(3) Tests for determination of radiation levels at, for example, 5 and 30 centineters frow the external surface of the finished source averaged over an area not to exceed 100 squire centimeters.

H. Additional Information

Submit any dodtional information, including experinental studies and tests that may have been performed on similar source designs, which will facilltate a determination of the safety of the source and efficacy of its use in the custon device. 


\section{DRAT}

A GUIDE FOR PREPARATION OF APOLICATIONS FOR

LICENSES TO USE SEALEO SOLRCES CONTA!NING

BYPROOUCT WATER!AL IN MONPORTABLE GAULING DEVECES

Nuclear Regulatory Commission

Division of Fuel Cycle and Material Safety

Material Licensing oranch

Washington, DC 20555 


\section{TABLE OF COHTENTS}

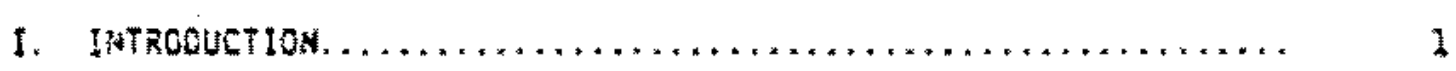

11. FEES $\ldots \ldots \ldots \ldots \ldots \ldots \ldots \ldots \ldots \ldots \ldots \ldots \ldots \ldots \ldots \ldots \ldots \ldots \ldots \ldots$

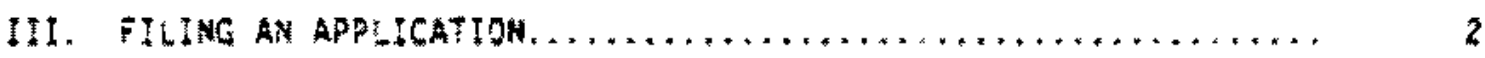

Items $2,3,4,5$ 5: Applicand, Malling Address and

Item 6:

Item 7:

Item 8:

ttem 9:

Itans $10 \& 11$ :

Item 12:

Item 13:

Iten 14:

1:2स 15: Leations of Use. $\ldots \ldots \ldots \ldots \ldots \ldots \ldots \ldots \ldots \ldots \ldots$ Individual Users $\ldots \ldots \ldots \ldots \ldots \ldots \ldots \ldots \ldots \ldots \ldots$ Radiation Protaction officer.......... Byproduct Materfol, Forms and Uses...... 4 Storage of sealed sources............... Nadiation Detection Instruments......... 5 Personnel Manitoring.................... Facilities and Equipment. . $\ldots \ldots \ldots \ldots \ldots \ldots+$ b Waste Disposal...................... Radiation Protection Progran.......... 7

a. Servieing Operations $\ldots \ldots \ldots \ldots \ldots \ldots$.

b. Controli ing access ta Devitas....... 8

c. "Lock-out" Procedures..............

4. Lak Testing of Sealed Sources... $\ldots \ldots$,

Items 15 3 17: Qualifications of Individual Users....... 9

Itan 18: Cartifitation..................... 10

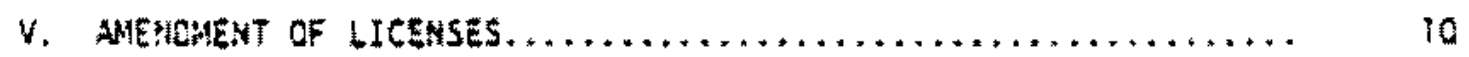

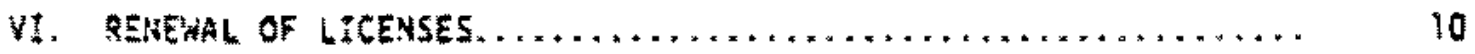

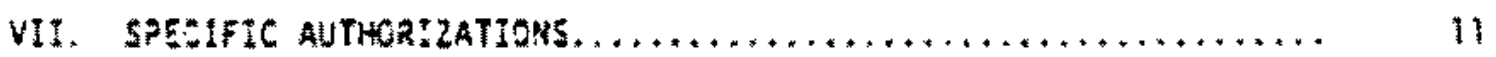

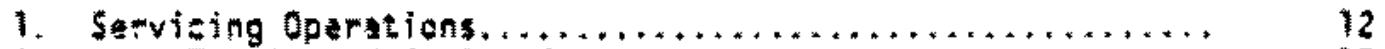

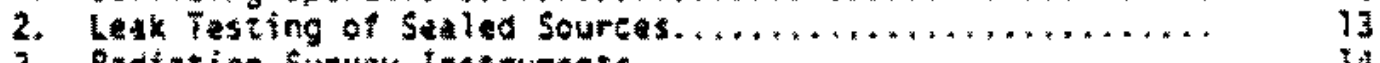

3. Radition Survey Insiruments....................... i 


\section{INTROOUCT1ON}

This gufde describes the information needsd to eraluate applicationis for spectic licenses for receipt, possession, and use of sealed sources containing byproduct material in nonportable gauging devices, i.e., gauges mourted in "fixed locations, for measurement and/or controt of material density, flow, level. thickness, weight, atc. In addition to the contents of this guide, aplicants should refe to the reguirements in the comission's regulations listed below. The applicant should carefully read the regulations. Inis guide is not a substitute for an uncerstanding of the regulaticas.

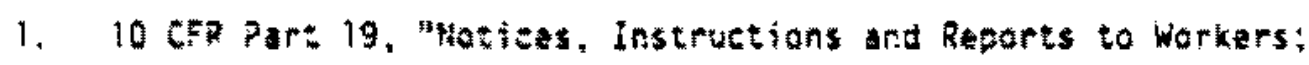
Inspections."*

2. 10 CF Part 20, "\$tandards for Protection Against Radidion."

3. 10 CFR Part 30 , "Rules of General Applicability to Licensing of Byproduct Material."

4. 10 CFR Part 170, "Fees For Facilities and Materials Licenses, and Other fegulatory Services Under The Atomic Energy Act of 1054. As Amended."

11. Hegs

The applicunt should refer to $10 \mathrm{CFR}$ Part 170 , section 170.31 "wehedule of Faes for Materials Licenses and Cther Regulatory Services," to detarmine 
the amounc of the fees which wust accompany the application. No action will be taken on applicaticas flled without the proper fee. Checks should be made paydole the U.S. Nuclear Regulatory Comission.

\section{FILING AN APPLICATION}

Two copies of the Form NRC-313 should be submitted in accorgance with the instructions on the form and should provide, as a winimum, the information described in this guide. Since licensees are required to comply with Comnission mules and regulations, license conditions, and the content of the subaitted apolication, we suggest that the apolicant prepare and retain one copy for reference. Spact on the form is linited, additiona: information should be provided on attachents to eaten copy of the form. Atiachents should clearly reference the applicaole itams on the form for which seditonat information is being provided.

Applications should concain sufficient information to enab the comnision to tave ciear understanding of the sctivities to be performed by the applicun. Sumital of insulficient information will result in delays in isswance of gre license. Applications should be matled co:

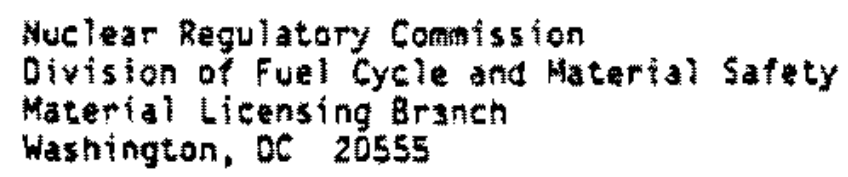

Except for Iten I which is selfmexplanatory. the following provices discussion of the mintmum information needed for each item on the form NRC. 313 
Itens 2.3. 4. and 5- Aoolicant. Malling Address, and Locations of Use:

The apolicant, comporation, or other legal netity should be specifled by name in ltem 2 and mailing audress in Item 4 . The name and ceiephane number of the indixidual who should be consacted concerning the application should te provided in Item 3. Individual should be destghated as the applicant only if they are acting in a private cspacity and the use of cyproduct material is not connested with their employment with a corsoration or other legal entity.

The actual location(s) where the byproduct material in sealed sourses, source nolders, gauges, ete, will be possessed, stored, andjor used should be specified in Item 5. Such location(s) should te elearly icentifted by road of saret name, numer, city and statk. A Post oflice Box number shoula not appear in Itent 5.

Len 6 - individual isers: The name of the individual(s) who will use (operaty) andor supervise the use of the devices listed in the application must be listed in Item 5 . An adequate number of trained users should be listed ta provide for continuity of operations. Hormally, an individual user should te physically present when the devicas are in use.

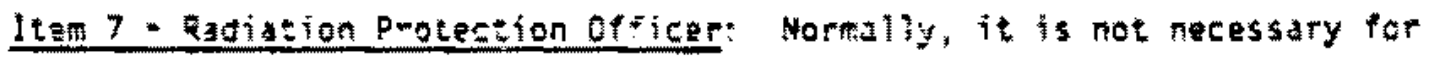
wszrs of nencortable jaiging fevicas to designate a radiation protaction officer waless there are multiple users and gouges within the plant or facility. However, the applicant should list the name in liem 7 of an individual user, superyitor, foreman, or other deshgnatud individual who has been assigned responsibllities for determining that: 
(a) Ail byproduct materials, sealad sources, and devices in use and/or in the posseszion of the apolicant are limited :0 trose listed in the license and are being used for the purposes spectiled in the license.

(b) Only those ineividuals authorized by the license use or supervise use of the devices.

(c) Periodic leak tests of the sealed sources are conducted as required by the license.

(d) The established "lckk-cut" procedstes are followed during nain" tenance or rabairs en or arzund the pipes. tariks, wessels, conveyors,

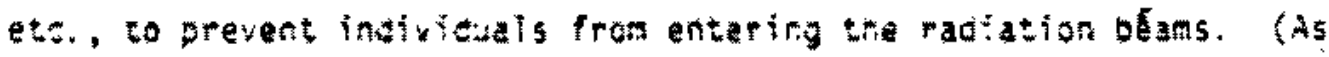
shewn in item is of this aulte, "lock-out" procadures nust be destribed in the apolication for certain tyces of devices.)

Iten a - Eyoroduct Waterial. Formx and Uses - Each radioisotoge to be used shevld be specified in Itan $8 . A$. and Item 8.8 . should show that the bypraduet material is to be possessed and usad is in the form of sealed source(s). The name of the manutacturer and nodel number of the sealed source hould of shown in Item 8.C. and the total activity, in willicuries, in the sealed source should be provided in leen 8.0. Itean 8.6 , should scectify the manufacturer and model number of each gauge, source holder or device in wich the byproduct material and sealed sourea descrited in Items 8.A. through 8.0. will be used. In addition, Iten S.E. should 
cescribe the purpose for with the device will be used. Sone examples of the hinds of information to be providea in Item are as follows:

\begin{tabular}{|c|c|c|c|c|}
\hline A. & 8. 8 & 8.c & & 3.2 \\
\hline Cestun-137 & Sealed sources & $\begin{array}{l}X Y Z, \text { Ine. } \\
\text { Model } X Y Z=1\end{array}$ & & $\begin{array}{l}\text { Not to exceed } \\
\text { loo willicuri } \\
\text { par sourse }\end{array}$ \\
\hline Cobal $1+50$ & $\begin{array}{c}\text { Sealed sourcas } \\
*\end{array}$ & $\begin{array}{l}\text { Mesa Verdin } \\
\text { Hodel } A-34\end{array}$ & inc: & $\begin{array}{l}\text { Not to exceed } \\
1500 \text { millin } \\
\text { euries per } \\
\text { source }\end{array}$ \\
\hline
\end{tabular}

$(\cos 21 t-60$ sesled sources
Rio Grande, Inc. Model RG=1
Not to exceed 500 mitliticuries per source e. $E$.

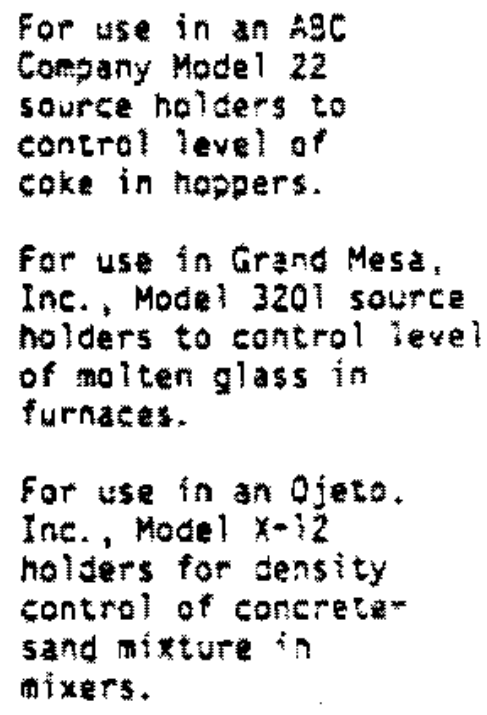

For use in an Ojeto. Ine., Moce $1 x-12$ nolders for density control of concreta* sand mixture in 角xers.

Item 9 - Scorage of Sebled Scurces: Since seaied sources are nomally reroved from gasing devices by the manufacturer or supoliar of the devices, it is onty nectsasy to reference 1 tem 8 in :ten $9 . A$, of the application for informstion regarding storage devices, $1 . e$. storage in the gurging devices only. Agplicanes wo will renove or relocute gatging devices (refor to sattion vil in this gut fa) should jescribe storage devices (if any) and storage areas (refer to Item is in this guide).

Iteas 10 and 11 - Gadiation Detection Instruments: For routine use of devices, radiation survey and aeasuring instruments are not normally 
requited. Applicants who whll perform other actutities which require the use of radiation detection instruments should provide the applicable information described in section VII of this guide.

Item 12 - Personnel Monitoring: For routine use of devices, the use of personnel monitoring devices (fill badges or thernoluninescent dosimeters) are not normally reguired. Applicants whe want to perform nonrout ine activities which will require the use of personnel monitoring deyices should provide the name of the supplier of the monitgring devices should provite the nane of the supplier of the menitoring devices and the frequency of exchange for frocessing by the supplier. For guidance concerning pe-sonnel moriltoring rkquirenents, the applicant should refer to section 20. 202,10 Cf? part 20.

Ees 13 - Faclilities and Equipment: The applicant should provide a description of the sulpment and fallities to utilize the devices containing the byprouct material. A simple arnotated sketeh or drawing shewing where ach depice is installed and the location of adacent ladders, aisles, or work areas employees will oceuoy should be provided.

Item 14-Waste Discosal: The applisant should describe the disposal method for saled sources containing byproduct material when wse of the dovices cantaining the byproduct material is discontinued. If the suppliet wit remove the devices and sealed sources from the applicants facillity

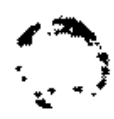
for sfspesal, this thould be so stated in the appltedten. If persons 
$+\infty$

or ccapeny other than the supplat will renove the devices and sejlad sources frem the apolitant's tacllity for return to the sucplier or transfer to an authorized recipient, the nunber of the NAC or threanest State license which outhorizes renoval and disposal of the apolicant's sealed sources and devices should be provited.

If the applicant will remove devices contating secled sources for return to the manufacturer or for transfer to another authorized person for disposal, this should be stated in the applieation. Section YII. 1 of this guide specifies the additional information which should be provided in the application for authorization to perform this operation.

Iten 15 - Radiation Protection Procran: For routine use of devices, the applicant should provide the following infermation:

(1) The name of the company or person who will conduct servicing pperations invaluting insta! attons, relocations, renculs, initial radiation surgeys, maintenance, repairs, and removal of the devices containing licensed taterisl and installation, repiactenent, and disposal of sealed sources containing litcensed matorial used in the devices. If any of these aperations will be performed by sumeone other than the supplier of the device, the applicant should provide the name and the number of the WRC or Agreement state license which authorizes Defformance of these operations. Applicants whe request wuthorIfation to perform any of the bove servicing operations stowid provide the information ceseribed in Section VIi.I of this gulde. 
$i_{i=1}$

(b) A deseription of how aceess to the devicas conatining byproduct matertal will be controllad. (garrats, warning figns, rencte or inecessible locations, control by individual users, etc.)

(c) For use of a device where it s possible for a majer portion of an indivioul's body to receive exposure to the radiation ban irom the sevict, a description of "lock-out" procedures, fit.e., procectures for preventing enployes frow entering the radbation beam durting matntenance, repairs, or athar wark on or around the bin, tank. hopper. pipe, etc., on which the device is mounted) should ge sumitred. If the device shutter or switen is locked, tolted. "tagged"of", etc. , until the work is completed, the applicant should describe this and provtd the nand of the individual(s) responsid to for enforcing this procedure.

(d) The procecuras for leak testing of the sealed sourtes. If the 5upplier of the tevicas containing the seded sources will perform leak sests of the sealed source in the applicant's facility, it is only recessary for the applicant to state this and to specify the frequency of the leak tests. If the applicant plans to use a leak test att, the nane of the supeliter and the model number of the leak fest kit should be specified. Applicants who will perform their own leak tests. i.e. collect the leak test wipes and analyze the wipes, should prowide the information described in Section VIX.2. of this gutie. 
The regutred frequencies for leak testing of sealod sourchis in nonoortable devices range from three month for alpta enitping byproduct naterial to 5 ix aonths for beta-gamo emicters. Sone sealed source/tevice combinations containing beta-gamna enitters have leak tast frequencies not to excked three years. Information concerning sealed sources and devices which have three year leak sest frequencies may be obtaineo from suppliers andor nanufacturers. Uniess a specific request for the three year leak test frequency is included in the application, a stxmonth freovency will be specifsed in licarses.

liams 15 and 17 - Cuallitications of Individul Users: The training and/or experiance of each individual named in Item 6 of the spolication rus: ae comensistate with the requested use and should te destribed in

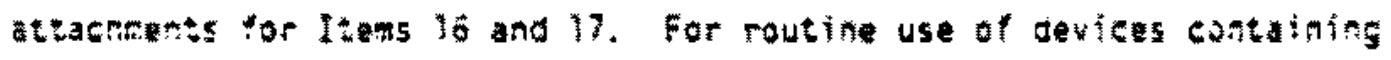
sealed suress, the training provided by the manufacturers at tue tine of installetion is sufficient to qualify individual users. iraining for nowroutine aperations te.g., Installation, reiccation, removal from zarvize. etc.) or training provided by someche other than the device manufa-turer aust we described in detail and submitted as an abtachment to the applizacion. As a minimum, the following infomation should be submi ted:

(a) The names and qualifications of the instructors.

(b) An outline of the trating progran. 
(c) The duration of tate trating program.

(d) The method for detemining iraine cospetency.

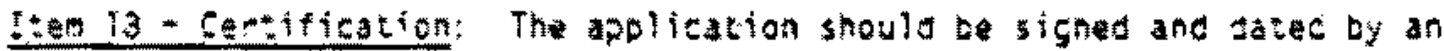

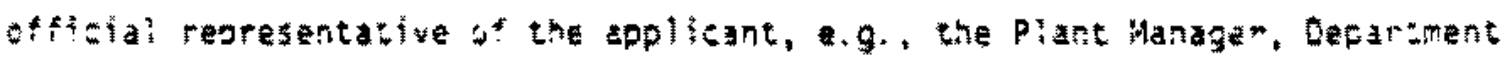
or Oivision Heat, Safety supervisor, etc, to certify that the application contains information which is true and correct to the best of the apelicant's kabslodge and bellef. Apolications which are unsigned will be reburnod for proper signature.

V. Amerowent of LICS:BES

Applicasticns for anendment of existing licenses way be filed in the same masner as intigal applications or nay be flled in letter form. The affication should elearly identify the lifense to be anended by license numider and spectly the exact nature of the requested changes to the icanse. Actitiona? supporting information, as necessary, should be previted.

*1. REAEDAL OF ICENSES

App! icstions for renewal of ficenses filed at least inirty (30) days prior to the axpiration date shown in the license remain in ef"ect until? lina: action has been completed on the application. mpotications filed after the expiration sate are cansidered to be new apolications. Appliteants needing ddditonal tiato prepare renewal applications should subais written requests for extension of the litense expitation date. 
Renewal applications should contain complete and up"to-date information concerning the applicant's activities to be conducted under the license. General references to previously ubnitted information (e.g:, see previous applications, see previous amendnent, ete.) or submittal of copies of the current license are not accaptable. The Form NRC-313 shoult be complesed in its entirety and documents submitted with the application should describe the applicant's current progran.

Appllcants may referarce previous applitations and/or documents in rendwal application proviced these are clearly ldentified by date. Where pertions of previcusly subatiter spolitations andor documents will be referencet in the ranewa application, these should be clearly identilied by date, at:achazt. number, sestion nuaber, and page number.

\section{VI: SPESIFIC ALTHORIZATIOUS}

This section describes the information applicants must provide in applications to the Cormisston for specific athorizations to perform any of the following operations:

1. Servicing operations on devices containing byproguct materials.

2. Leak testing of sealed sources except by means of latat test kits.

3. Calibration of radiation survey and asesuring instruments. 
Eaen of the above aro discussed, in order, in the following.

1. Servicing Decertions. Applicants who want to perform operations on devices involving insiallation, relocation, mainienance, repair, renoval fer disposal, ferformance of radiation surveys following Instaliation, etc. should provide the following information:

(a) The spectfic device(s) on which the operations are to se performed.

(b) deseription of each specific operation to be pertoraed.

(c) The tep-by-step procedures to be followed in performing each operation including a description of the ratiation satety procedures wic: will be tollowed.

(a) The name of ach incividual who will perforn the services.

(e) An outline of tre sraining receives by oach andividual who wil? perform the oparation. This iraining stould incivoe instructions In the performance of each specitic operation: the step-oy-step procedures to followedi radiation safety and the use of radiation survey instruments, "lock-0ut" procedures, i.e. procedures for securing the devich shutters and/or switches in the elosed or shielded position; and, if applicable, personnel monitoring requifements. 
ind

(1) A description of the gualifications of the individuals sho provided the braining in servicing of devices.

(a) If operations are oerformed which require radiation surveys, (e.g. installations or renovals) deseription should be pravided to show the locations of the radition aseasuraments and the kinds of recards to be maintained of the results.

2. Leak testino of sealec sources. Applfeants who want to pertorn latk tesss of sealec sources, i,e., collect the wipe bests and analyze the rasults, showid provide the following information:

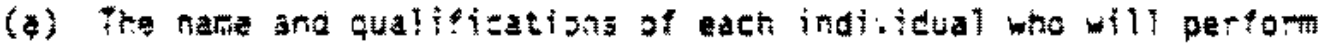
the Tatas ats.

(c) Procedures and materials to be used in coilecting test samples.

(c) The type, manufacturer's name, model number, and adatitith detection and messurenent characterizties of the instrwent to be used for assay of test samples.

(d) Instrument calioration procedures, including the nane of the manufacturer and model number of each standard source to be used; the nuclide and quantity of radioactive material in each standard source; the stap-by-step callbration procadures to be 
followed; and the nane and the experience and training of az: individual who will perform the callorations. In providing infomation concerning the standard sources used in the ca? bration, applicants should provide information concerning the accuracy of each source used. Each sourc: should be, as a mininum, * S percent of the stated value and traceable to a primary standard, such as that maintained by the National Bureas of Standards.

(e) The wethod, including sample calculation, used to conver: Instrument readings to units of activity, e.g. a microcuries.

3. Ratation slipey instruments. It the applicant will perform activities requiting the use of eadiation survey instruments, esch instrument should be described. The manufacturer's name, modei number and whe range of each instrument should be provided. If the apolicant will pertcra calibrations of the radiatica survey instruments, the following itformation should be provited:

(a) The manufacturer and nodel number of each radiation source to be used.

(b) The nuclide and quantity of radioxctive material contained in each sourse.

(m) 
$(2)$

(c) The accuracy of the source(s). The traceability of the source to orimary standard should be provided.

(d) The step-by-step procedures, including assoctated radition safety procedures.

(e) The nawe and the experience and training in instrunent caltorations for each person who will perform the calorations.

If the applicant intonss to cortract out the calibration of instrunents. the name, adoress, and license number of the fim shusld be spectict sogether with tha frecuency o* calforation for exch type of instrument.

An deagute calibration of survey instruments usually cannat be performed with the built-in check sources. Elactrontc calibrations that to not involve a source of radiation are also not actequate ts determine the proper functioning and response of all components of an instrument. Dahly or other frequent checks of survey finstranent: should be supplemented gyery 6 aonths wth a tworpotet calionation on each scale of each instrument with the two-points seodrated by at least $50 \%$ of the scale. Survey instruments should lso be caibraced folowing repair. A survey instrument mav be consideret oroperly calibrated wen the instriment readings are within $* 10$ percent of the calculated or known values for each point checked. Readings with in \$20 percent are acceptate if a calibration chart or grach is presared and attachac to the instrunent. . 



\section{APPENDIX E}

\section{ALASK AN AIR COMMAND TRITIUM LIGHT EVALUATION}

\section{"BRIMFROST 83"}



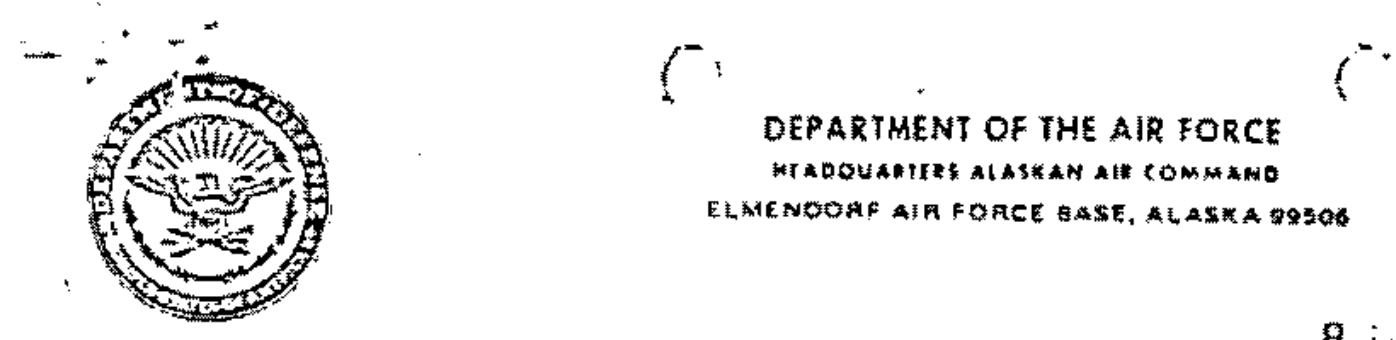

DEPARTMENT OF THE AIR FORCE

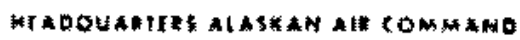

EDAIENEOAF AIR FOACE BASE, ALASTA

line Doos (Major Hult, $552-5346$ )

whit writium Runway lighting rest

wo See Distribution List

1. Tritlum runkay lighting was evaluated by the Alaskan Air Comand during BRIM FROST 33 . The test denonstrated that the lights can be deployed, operated, and mantained in austere arctic conditions. Aircrew coments reflected that the lights were not as operationally effective as anticipated. However. we are optimistic that with engineering modifications or the addition of extra Iighting, operational capability can be greatly improved.

2. Atmachment 2 is a report on the tritium lighting evaluation. Additional guestions nay be addressed to our Poc, Major Hult. Av $317-552-5346$.

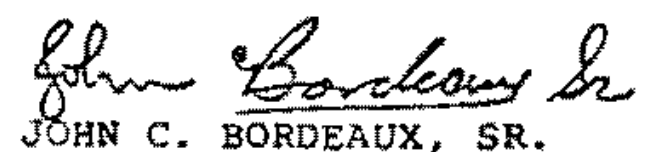

Colone1. USAF

DCS/Operations

2 Atch

1. Distribution List

2. Operational Report on the Tritium Runway Lighting Test Conducted During BRIM FROST 3

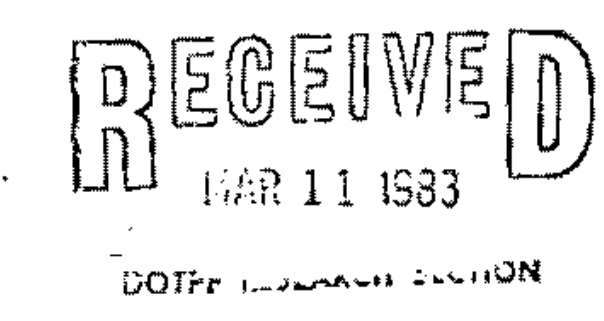


r.

Operational Report on The Tritium Runway

Lighting Test Conducted

During BRIM FROST 83 


\section{PROBLEM}

1. Alaskan Air command has unique requirements for portable runway lighting : First, the arctic environment makes installation and maintemance of lighting equipment difficult and hazardous. Also, during winter periods the hours of useable daylight are few, making it mandatory to have 1 ighting to support air operations. Finally, the commitment to support joint AF-USA exercises requires dependable runwa lighting:

2. The purpose of the tritium runway light test was to evaluate its capability to support Alaskan Air Comand operations in the arctic environment. This included the following objectives extracted from the AFESC/RD test plan:

a* Storing, shipping, handling, installing and naintaining the liphts.

b. Physical and environmental safety and security aspects.

c. Acquisition range ot the lights under varying conditions and for different aireraft.

\section{BACKGROUND}

1. package of tritium powered Iights was developed for the test project, These included runway edge, vast, lead in, and wind tee.

2* The lights and test personnel were transported to Alaska and. clear Creek La by ANG a ircraft.

3. The lights were installed and operational approximately $20 \mathrm{Jan} 83$ and remained in position until 2 Feb 83.

4. C-130 and helicopter crews operated into clear creek and completed test questionnaizes.

5. Linited $A-10,0-2$ and $C-12$ sorties (low approach) were also flown against the tritium lights.

6. The light system was setup at Malamute Da, Fort Richardson,

5-7 Feb 3 for 5 tate of Alaska Testing. One 21 TFh C-12 sortie was lown during this test.

7. On 8 Feb 83 Battelle Alaska was given custodial responsibility or the lights.

8. On $5 \mathrm{Feb} 83$ the tritium lights were stored in the 21 CSG Prime Beef Readiness Equipmemt building. 


\section{DISCUSSION.}

\section{Maintenance and Safety.}

There were no problems identifled with storing, shipping, handing, installing, or mantaining the tritium lights during the test. The lights were deployed srom Fort wainwright to clear Creek via helicopter and subsequently installed on plastic bases. These fixtures were secured at designated positions along the runway by freezing in place. Several fixtures were overturned by C-130 prop blast but sustained no damage and were returned to sarvice.

\section{Security.}

Prior to the BRIM FROST 83 test, much concern was raised about the tritium lights being removed, stolen, or vandalized. Because of the physical conditions at clear creek and Iimited security personnel dvailable, it was decided that risk was within Iints and this would be an undefined evaluation factor. Results in this area were totally satisfactory. Throughout the test peziod only one light was removed, retrieved immediately, and returned to service. This one isolated case is insigniticant when considering the large number of USAF and USA personnel involved at cleat creek, the length of deployment, and lack of active security measures.

\section{Aircrew Evaluation.}

\section{a. Acquisition Range.}

(1) Range at which pilots could visually acquire the tritium lights was considered a critical evaluation factor. Throughout the test it was shown that acquisition range was highly dependert upon the level of light from external sources. Range decreased greatly with dawn and dusk or with a full moon and clear skies. Under ideal ark conditions, range varied from one to two miles and was dependent again on several factors. First, pilots of slower aircraft such as helicopters acquired the lights sooner than faster/larger arcraft such as the C-130. Also, range seemed to increase with increasing pilot familiarization with the tritiun lights. Also, the lead in and VASI panels were acquired sooner than the smaller runway edge lights, which was expected, considering the differences in light fixture frontal area.

(2) The USA UH-60 pilots considered the tritium lights entirely satisfactory for their mission. whey evaluated both visible and infrared (IR) lightirg and rated both excellent.

(3) 0-2 pilot participation in the test was minimal. Consensus was that the tritium lights, in the present configuration, would be as acceptable as the alternative nethod of runiay idencification, coleman type fuel laterns. Actuistion range, under jaed'conditions, was one to two miles and tended to improve slightly with familiarity. 
(4) A-10 pilots participation in the cest was minimal. ouestionnaires received showed erratic aircrew responses which did not provide any meaningtul information. A primary reason was undoubtedly due to pilot unfaniliarity with the tritium lights.

(5) c-12 pilots acquired the tritiun lights at one to two miles under ideal conditions. Range again improved with the familiarity*

(6) C-130 pilots tended not to acguire the lights as guickly as pilots of smaller, slower moving aireraft. Even under bost conditions they felt range was between one-half and one and one-half miles. This, agatn, is probably due to airoraft size and approach speed.

b. Runway Alignment. Nost pilots felt the tritium lights provided useable alignment information from about one mile. This was considered satisfactory for slow moving aircraft which rould be afforded additional time for correction. Pilots of higher speed aircraft felt the tritium lights provided minimal time for alignment and forced go arounds were a definite possibility.

c. VAST Jights. The tritium VASI system was a simple three bar systen. Acquisition range for most pilots was one to one and one-half miles. However, useable range fable to discern glideslope deviation) was generelly put at about one half the acquisition range. Most pilots considered the VASI system, as configured for this test, a limited cross-check systen rather than a total glideslope guidance system.

d. Runway landing zone/Edge 1 ights. Only un-60 and $c-130$ aircraft landed using the tritium light systern and nearly all pilots considered them adequate for safe landing. 0-2, A-10, and C-12 aircraft flew low approaches only, but these pilots felt a safe landing could have been made.

\section{CONCZUSION}

The test completed during BRIN Fost 83 showed the durability and. dependability of the tritium lights. It also showed the system, as now designed, can probably support the operations of small, slow moving type aircraft. For larger, faster moving aircratt the lights offer only maxginal performance and would have to be supported with other lighting aids to be totally acceptable.

\section{RECOMAENDATTONS}

1. Whe vse of tritium runway lights, presently designed, should be 1 injted to supporting operations of small, slow moving aircraft like $0-2 \mathrm{~s}$ and helicopters.

2. Aircrews must hav̈e the opportunity to fly approaches to the tritium lights, in a controlled training environment, prior to any operational deployment. 
3. Visual acguisition range must be improved oy redesigning the lights andfor providing an aditional location a d.

4. Further testing and evaluation is required to deterine the feasibility of tritium lights to support A-10 of C-130 operations. 
APPENDIX F

SAMPLE QUESTIONNAIRE AND EVALUAT ION SUMMARY

MALAMUTE LANOING ZONE, ALASKA, FEBRUARY 1983 

To be completed by all observers:

This questionnaire is intended to act as a semi-formal data gathering method which will help determine the overall effectiveness of the RuL system as well as identify areas where further testing, development, or improveraents are needed.

Name of Dbserver

Affiliation

Address

Telephone

OBSERVATION DATE:

TIME:

LOCATION:

1) Are you a licensed pilot?

Yes $\square$ No

2) During the observation what would you estimate was the maximum distance which you were able to see any of the R-L lights.

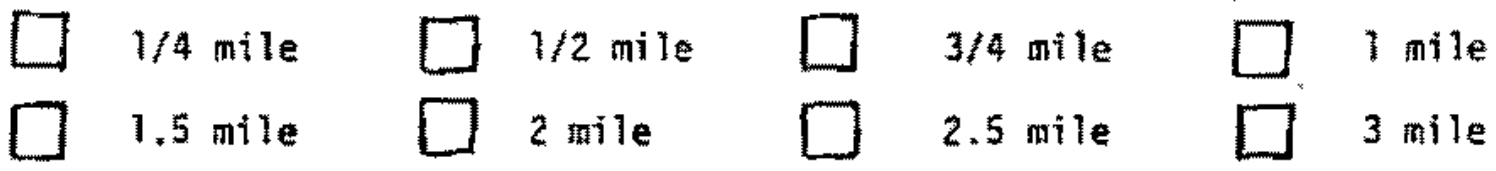

3) The first R-L Lights which you saw were:
D Lead-in markers
$\square$ VASI
$\square$ Wind Tee
[ Runway Edge Lights

4) While in the traffic pattern were you able to maintain reference of the runway by use of the R-L Lights?
$\square$ Yes $\square$ No
Cominents:

5) While on final approach did the R-L lead-in markers help you plign with the runway?

$\square$ Helped very much $\square$ Helped somewhat

$\square$ Did not help Comments: 
6) Did the R-L VASI assist in maintaining glide slope?

$\square$ Helped very nuch $\square$ Helped somewhat

$\square$ did not help

Comments:

7) Did the R-L VASI assist in horizontal runway alignment?

$\square$ Helped very much $\square$ Helped somewhat

Did not help comments:

8) In your opinion, is the R-L VASI a practical landing aid for runways 4000 feet and under?

$\square$ Yes $\square$ No $\because$ Comments:

9) Was the $R-L$ Wind Tee clearly visible? $\square$ Yes $\square$ No

10) Was the R-L Wind Tee easily interpreted?

$\square$ Yes $\square$ No comments:

11) In your opinion, is the R-L Wind Tee practical landing aid?

$\square$ Yes $\square$ No comments:

12) Were you able to see the R-L Runway Edge Lights from a distance which would perait adequate time for final approach corrections?

$\square$ Yes $\square$ No Comments:

13) Did the R-1. Edge Lights give adequate deftinition to landing zone?

$\square$ Yes $\square$ No comments: 
14) Were the reflectors on the R-L light fixture bases of assistance during landing?

D Yes No Comments:

15) What is your opinion of the color of the $R-L$ phosphor?

16) Were the R-L taxi-way lights adequate to define ground control?

17) In your opinion, is the R-L lighting systen which you have observed suited for application in Alaska in its present form?

$\square$ Yes $\square$ No $\square$ Yes with improvenents and modifications

18) What inprovements and modifications would you like to see?

19) General Comments:

Thank you for your cooperation. Please return to:

Lee Leonard

Research Section

Alaska Department of Transportation

and Public Facilities

2301 Peger Road

$\therefore \quad$ Fairbanks, AK $9970 \mathrm{l}$ 


\section{R-L QUESTIOHNAIRE}

SUAMARY OF RESULTS

From: Halenute Field Test

Fort Richardson, Alaska

February 5 \& 1983

TOTAL NUNBER OF QUESTIONNAIRE RESPONSES: 23 REsponses

NDIE: Questionnatre attached for reference.

\section{QUESTION 1}

22 respondents were licensed pilots

1 was not a licensed pilot.

9 people observed from $\mathrm{C}-130$.

5 people observed from $\mathrm{C}-12$ (Beech King Air Light Twin)

6 people observed from Cessna 206

8 people observed from Huey helicopter

Note: Some individuals observed lights from two or more dircraft during the test period.

Conclusions:

Essentially all of the queried abservers were licensed pilots.

QUESTION

$\begin{array}{ll}1 \text { mile }-1 & \text { li mile }-3 \\ 3 / 4 \mathrm{Mile}-7 & 2 \text { mile }-4\end{array}$

I Hile -6 Mile -2

\section{Conclusions:}

Fifty-six percent of the observers acquired the lights in the $3 / 4$ to 1 mile range while $39 \%$ acquired then at greater distance which would indicate that 1 mile would be a nominal acquisition distance to report under the weather conditions experienced during tests.

\section{QUESTION}

Lead in lights - 18

VASI - 3

Edge lights - 2*

Cunclusions:

Seventy-gight percent acouired the lead-in ligits first and rany felt that some form of the lead in systean wes necessary to any Rut. System. 
QUEST1ON

Yes -8

No -15

Conclusion:

Downind reference of edge lights was not good*-65\% not able to keep track of lights while 35 did. However, $C-130$ crews were using 11 to 2 mile fron runay downinds while cessna 306 was blocked fron seeing lights on downind because of low celling and the interference of the tree line.

QUESTION

Helped very much -17

Helped somewhat - 6

Conclusions:

One hundred percent of observers felt that the lead-in lights were helpful.

\section{QUESTION \#E:}

Helped very much - 5

Helped sonewhat -10

oid not help - 5

No comment -3

Conclusions:

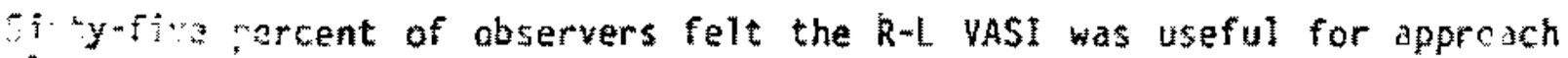
i. e.

\section{QUESTION H}

Helped very much - 4

Helped sonewhat - 11

Did not help - 5

iro comnent -2

Conciusions:

Sixty-five percent of observers felt the R-L Vast vos useful for hurizontar aligment, although later in the debriering the concensus steved to the that this use of the WASI was insignificant. 


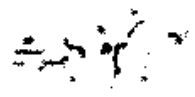

QUESTION ER:

Yes -13

No - 6

No choice -4

Conclusion:

Fifty-seven percent of observers seened to think that the $R+L$ VASI was a significant landing aid. The difference between this percentage and that shown in question \& \& 7 seems to reflect the reeling of some that for light aircraft a WASI is not normally required.

QUEST1ON \#9:

Yes - 9

No $* 12$

No choice -2

Conclusions:

The reaction of observers to the wind tee was not very favorable. However, the concensus seems to be that the wind tee which was used was too stall to permit adequate definition. Redesign should improve this probiem.

QUESTION

Yes -4

No -14

No thoice - 5

Conclusion:

Sane as 19.

QUESTION "II

Yes -7

No - 10

lio choice -6

Cunclusion:

Säne as 


\section{QUESTION}

$$
\begin{aligned}
& \text { Yes - } 16 \\
& \text { No }-5 \\
& \text { No choice - } 2 \\
& \text { Conclusion: }
\end{aligned}
$$

Seventy percent of the observers felt that the R-L System permilted adequate time for final approach corrections while $28 \%$ did not. This would indicate that $70 *$ wrould be confortable landing to the system while $22 \%$ would be hesitant.

\section{DUESTION \#13}

Yes -18

No -3

No choice -2

Conclustons:

Seventy-aight percent of observers felt the landing zone was adequately defined by the systen while only 132 did not. We interpret this to mean that $13 \%$ were dissatisfied with the distance at which they could acquire runway defintion.

\section{QUESTION 管14:}

Yes - 11

Ho -8

No chotce - 4

Conclusions:

Forty-eight percent of observers felt the reflectors were helpful while 35\% did not. This result is highly dependent on the aircraft fron which the observation was made and the pover of the randing lights. The reflectors were considered inportant by the C-130 observers and not very helpful to the light aircraft.

QUEST10N \#15:

Adequate -20

Inadequate -2

lio contrient - 1

Conclustuns:

Only two observers or ge objected to the color of R-L lights. 
QUESTION N16:

Adequate $* 19$

Inadequate - 1

No comment - 3

Conclusions:

Only 1 observer or $4 \%$ did not feel the taxiway lights were adequate for ground controi.

QUESTION H17

Yes - 2

No -3

Yes wimprovements - 18

No comment - 0

Conclusions:

Eighty-seven percent of the observers felt that the system would be suitable for application in bush Alaska at runways 4,000 feet and less. However, the najority of these (78\% of all observers) felt improvenents were needed to the systen which they observed.

\section{GENERAL:}

Of a total of 368 possible qualitative answers fron the 23 observers the following results were obtained:

Sixty-five percent were positive answers showing confidence in the system as a whole.

Twenty-six percent were negative answers suggesting that the system was not yet adepuate for the use intended.

Nine percent were neutral. 
APPENDIX 6

FAA RESPONSE TO RL LIGHT TESTING DURING FEBRUARY 1983 


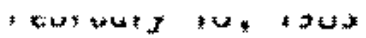

AL $-F 5 D O-6]$

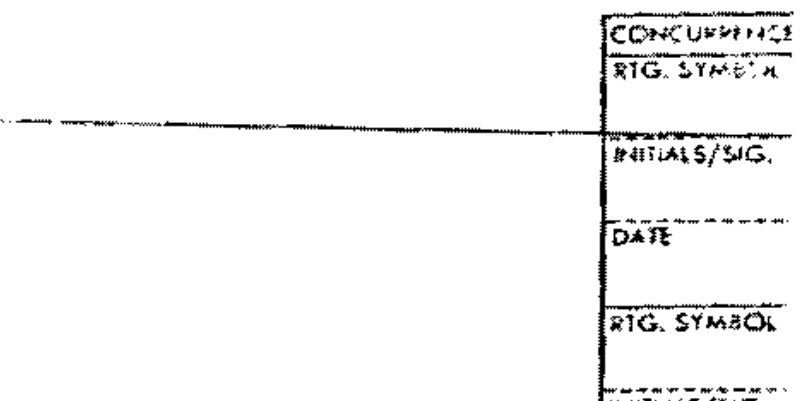

Hanager, AAL 200

The Alaska Department of Transportation Research Section, werking with the Alaska Air Vational (uard. FAA Flight standards and the Army Nationa? Guard, conducted a demonstration of a radioluminescent light (R-L) system at Malemute Fleld, located three miles from Ft. pichardson's bryant Airfield. To test the lighting systen's effectiveness for airoraft in different perfomance categories. Lockheed Hercules $\mathrm{C}-130^{\prime} \mathrm{s}$, a Cessna 206, and Huey Helicopter were used. The $c-130$ demonstration was conducted on February 5, 1983. A Cessna 206 fllght, scheduled for Febr ruary 6th. had to be cancelled for weather. This flight and the Huey Heilcopter fight were accomplished the following evening.

The lighting system consisted of lead in lights, vas! panels, a lighted bind cone, and runway edge lights. During our observatoons, participants unanamously agreed, lighting system usefulness and rumay acquisitoon wee enhanced with experrence. The R-L system does not have the light intens ity or color of a standard incandesent lighting system, thus reducing the useful range and changing the rumay characteristic appearance.

With lead innlfohts, the airfield was viblole from $2-3$ miles. This provided pllots sufficient time to achleve proper alignment in all aircraft perfomance categories. Without the lead in lights, rumay acquistition wavacos difficult and left insufficient fime for the $\mathrm{C}-130^{\circ} \mathrm{s}$ to nake final approach alignnent corrections. Light alrcraft flown by pilots faniliar with the system were able to operate with only threshold and edge lights. The helicopter did not have difficulty with either lighting configuration, having the advantage of reducing pround speed to meet visibility conditóns.

The VASI light provides valuable ass istance in mantalning glide slope and horlzontal allgruent. With light intens ity aftecting depth perception, particularly with blowing snow, this was a practical anding aid. Irstead of the oormal red over whte VASt presentation, the R-L system usad three light panels that, when aligned in a hat shape fashion, gave ar on glide siope indication. After several approaches, the new vas systen was comportable to use. 
Runway Edae LIghts gavie adequate defination of the Tanding zone and were excellant for taxijing. When used without lead in lights, romagy accuisition was difficult but the range could be extended by concentrating more liahts in the threshoid touchdown area. Again, operating with olly mantiay edge lights reguires experience with the Igight system to bein locate the nonway. Runway edge lights should not he considered adequate for a sole means of locating an airfleld. Mavigational aid intersections, terrain features, and pilotage would enhance airfield acquisition.

The R-L Lighting Systen combinations are well suited for ruaz Alaska locations without electrical power. With the availability of lead in lights, VASI systems, and runway edge lights, combinations may be de= veloping to satisfy operator requirezents. The $R-L$ system, unlike fiare pots, provides light continuously, requires no maintenance, and operates effectively in all weather conditions. By using the lead in Jights for timely runway acquisition, VASI lights for horizontal guidance, and the runway edge lights for runway identification, it appears operations would be limited only by rumway length and surrounding terrain. 
APPENDIX 4

EECHICAL WORKING GROUP TEST AND EVALUATIDN

SEPTEMBER 7 AND 8, 1983 

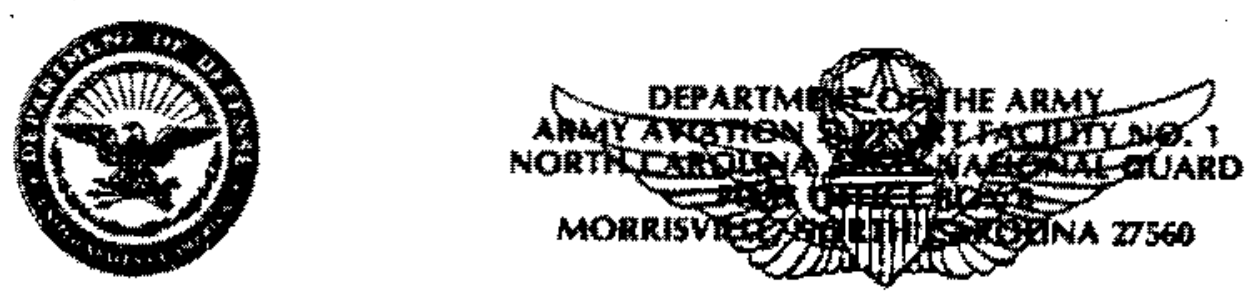

AASF 渵

15 September 1983

MEMORANDUM FOR RECORD

SUBJact: Test and Eyaluation Profect Firefly $7-8$ sep 83 at Camp Mackall

1. As per discussion, Mr. Remint requested the undersigned to releage this report as the orficlal minutes of the TWG conference held and test and evaluation conduct. ed at Faleigh and Camp Hackall, tc on 7-8 sep 93 in oxder to expedite prograw intormation to all recipients.

2. Members of the ThG met on the afternoon of 7 sep for the purpose of reviuwing and finallzing the test program for that aight. Duting the afternoon the runway at Mackall to be used ( $\mathrm{RW}$ DA) was set up for the might" ${ }^{*}$ testing (see Incl \#1 for Camp Mackall A1rfield layour).

3. The primary purpose of this test was to determine if increasing the number of cubes per Fuxture vould provide the required acquisition distance of $4-6$ telles for USA Utititary Airlift Comand (Mac) use. The tuxtures used for threshold landing and touchdown zone lights vere non-reflectorized and contained muttiple tubes. The runway edge lights were reflectorized and contalned one tube for each fixture. The 1ights were deployed as depicted on page 5-10 MACR 55-130 (Inal ha) winus the rad lights to thark the end of the runway.

4. Tearing at Macka11 conf1rmed that increasing the number of tubes does increase the acquisition distance of the 1ights. Distances in excess of 6 miles were identiFled for acquiring the lights and in excess of 4 miles for identifying "breaks" in the lights (see Incls $2,5,6,5$ ) for cest results). The runway edge marker 11 ghts (reflectorized one tube) were not adequate to provide the destred "defintcton" For Funway identifleation. The tour tube round oblong container used in Alaska tests

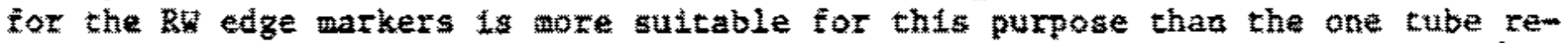
flectorized wht.

5. Pertinent weather for this test was $20.000^{\prime}$ scatcered visibility of 7 miles, no woon, and relative humidty of $55 \%$.

6. The following conclusions were determined regarding the nights testing:

a. By tncreasing the aumber of tubes, acquistition and ideatification distances can be obtained weli with the stated needs of kac of $4-6$ miles.

b. The parabolic reflector containing one tube provides insufticient runzay edge Hghting to provide early runiay definition. 
AASF \#1

15 September 1983

SUBJECT: Test and Evaluation Profect F1refly 7-8 Sep 83 at Camp Mackall

c. The round oblong lighting flxture containing 4 tubes per fixture used in Alaska is belleved to be sufficlent for RW edge markers to provide early RW definition.

d. Additional work is required regarding engineering and hardware (human factor considerations) in constructing the fixtures, mounting apparatus, and shipping contalners.

e. More techniclans from Oaik RIdge must be dedicated to field testing for required support.

f. In that the purpose of the tritium lights was not intended as a navigatlonal ald but a landing ald, the committee should evaluate the use of a "beacon" or other light to be used as an aid to provide early acquisition of the airport environment.

7. A weeting was held on 8 Sep 83 wth the TWG commitee and other participating personnel in whtch the above conclustons were reached and generally agreed upon. (See Incl 13 for list of attendees and participating personnel.) The following Items were discussed and evaluated/agreed upon:

a. Mr. Realni, DOE, directed the following:

(1) ORNL is to obtaln two TEG's for powering strobe lights (beacon) and have both fully operational prior to the next fleld test.

(2) ORNL is to evaluate number needed and provide ORNL technicians in sufficlent numbers to support future fleld tests.

(3) ORNL is to inspect and 1nventory all hardware, supplies, fixtures, etc., prior to shlpment to verify contents and condition.

(4) Make coordination with Alaskan personnel to bring RW edge marker lights from Alaeka to kackall for next fleld test. George Jensen, BATTLIE volunteered to infliate coordination for same. meetings.

(5) LTC Everett, test director, to publish officlal minutes of test and

(6) ORNL is to coordinate/1nltiate time gotion study to determine number manhours to establish and have operational the alrfield lighting system. Also to deternine time required to "tear down" and prepare for movement/sh1pment. Study to include the optimum number of personnel to accomplish these actions.

(7) ORNL ts to maximlze efforts to improve and simplify all hardware, shipping containers, flxtures, mounting apparatus, etc., associated and needed with the lighting system.

(8) ORNL, time and resources permytting, is to engineer and construct red tritlum lights for marking end of $\mathrm{RW}$ use. Committee needs were identified to be four red fixtures (two for each side of runway) with 10 tubes per fixture (total of forty (40) red tubes). 
AASF औ 1

15 September 1983

SUBJECT: Test and Evaluation Project Firefly 7-8 Sep 83 at Camp Mackall

b. Visual Approach Slope Indicator (VASI) 11ghts are to be Included and evaluated at the next field test. VASI lights presently in Alaska are to be used in the event ORNL does not have time to construct the new tubes.

c. USAF Europe In Tw1x Message \#R301445Z Aug 83 to AFESC Tyadall AFB expressed interest in the tritium lighting system speciflcally for edge, threshold, and approach slope indicator lighting.

d. Mr. G. Grandy, an employee of Dupont with the Savannah Nuclear plant under government contract with DOE, attended briefings and testing of the 11ghts at Mackall. His interest was seeking a reliable, no external power supply lighting solution for marking obstructions to low level flight; 1.e., putting lights on top of poles, wires, towers, etc.

e. Mr. Remini and Mr. Hardy noted that AFESC, TAFB, had transmitted to DOE a military interdepartmental purchase request (MIPR) in the amount of $\$ 400,000.00$ to support continued development of the design prototype fabrication and the deployment/ evaluation of the radioluminescent airfield iights. A statement of work (SOW) spelling out testing in Alaska was Included.

8. In summary the test at Mackall validated the 4-6 mile acquisition distance needed by the USAF. The reflectorized one tube fixture is insufficient to provide early runway definition. The first generation RW edge lights used in Alaska will be used In the next test at Macka11. Target date for the pre-Alaska test is still tentatively scheduled for 2-3 Nov 83 at Mackall. A test plan for 2-3 Nov will be developed and distributed on or about 6 oct 83 . A VASI system will be incorporated into the next test.

7 Incls

1. Camp Mackall Alrfield Layout

2. Test Results Recap

3. List of Attendees/Participants

4. MACR 55-130 Extract

5. Tests $1-7$

6. Test 8

7. Test 9

DISTRIBUTION :

Mr. Remini

Mr. Case (2)

Mr. Nelson

MAJ Bell

Mr. Hardy

COL West

Mr. Jensen

MAJ Hobbs

MAJ Hult (2)

MAJ Olson

COL Guard

Mr. Gale

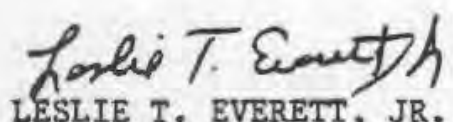

LESLIE T. EVERETT, JR.

LTC, AR, NCARNG

Commander, AASF 非 
VOnde' $/ D M E-B$
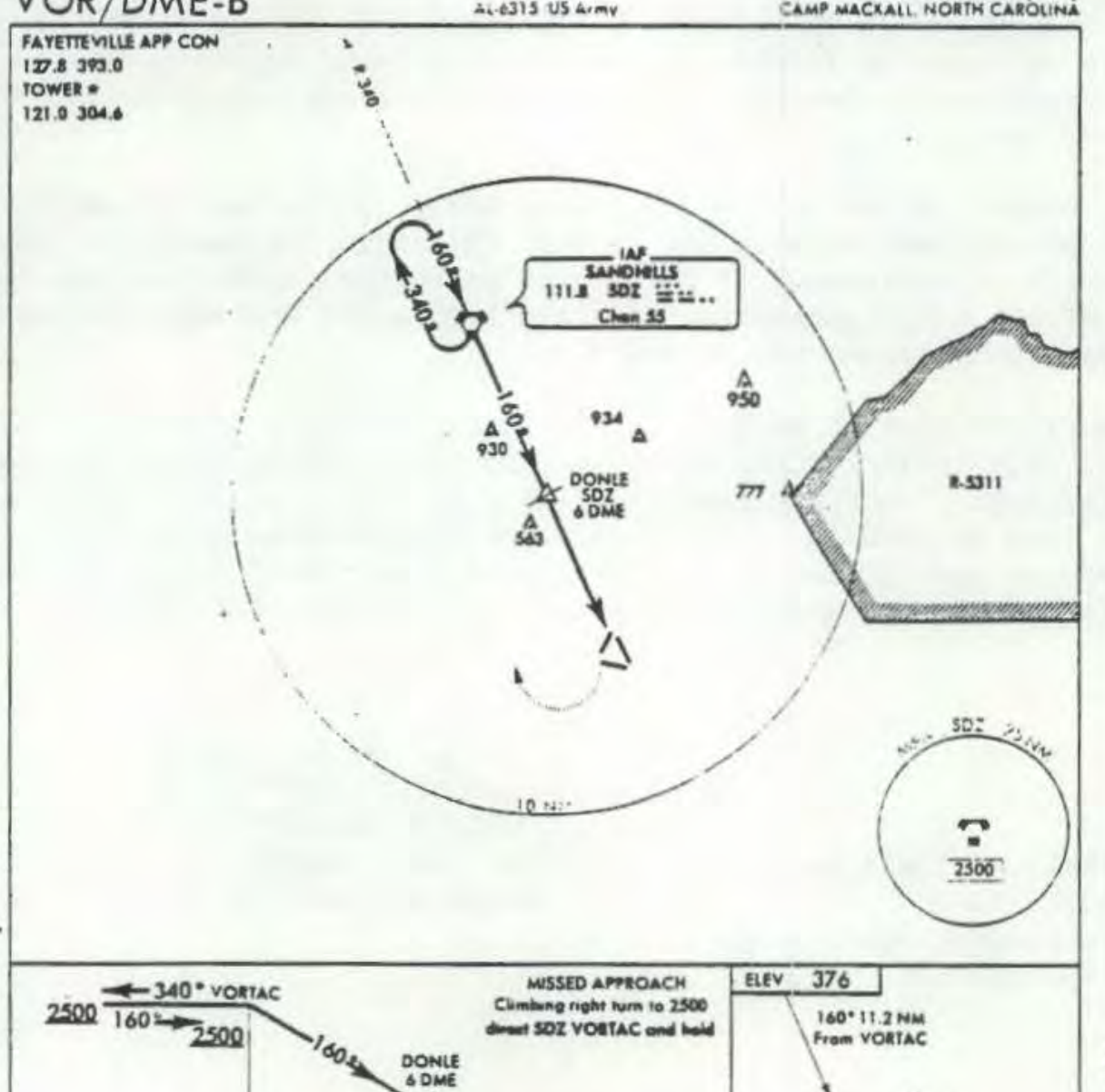

hoodure Nm NA

\begin{tabular}{|c|c|c|c|c|c|}
\hline CATEGORY & A & 1 & $B$ & $\bar{c}$ & $\bar{D}$ \\
\hline CARCunge & 8.40 .1 & 464 & $(30011)$ & $\begin{array}{l}840.1 \% / 2 \\
\text { 1500.1\%! }\end{array}$ & $\begin{array}{c}940-2 \\
\text { sed } 1600.21\end{array}$ \\
\hline
\end{tabular}

- Proesdure ner cuthorimed at night. When locei alinmeter not arsilabie. vee SimuONS Nef attimater sething and inereane all MOA's 120 toet.

$\Delta \mathrm{Na}$
100

* Lightirig syster SET up ON RW 4 AND
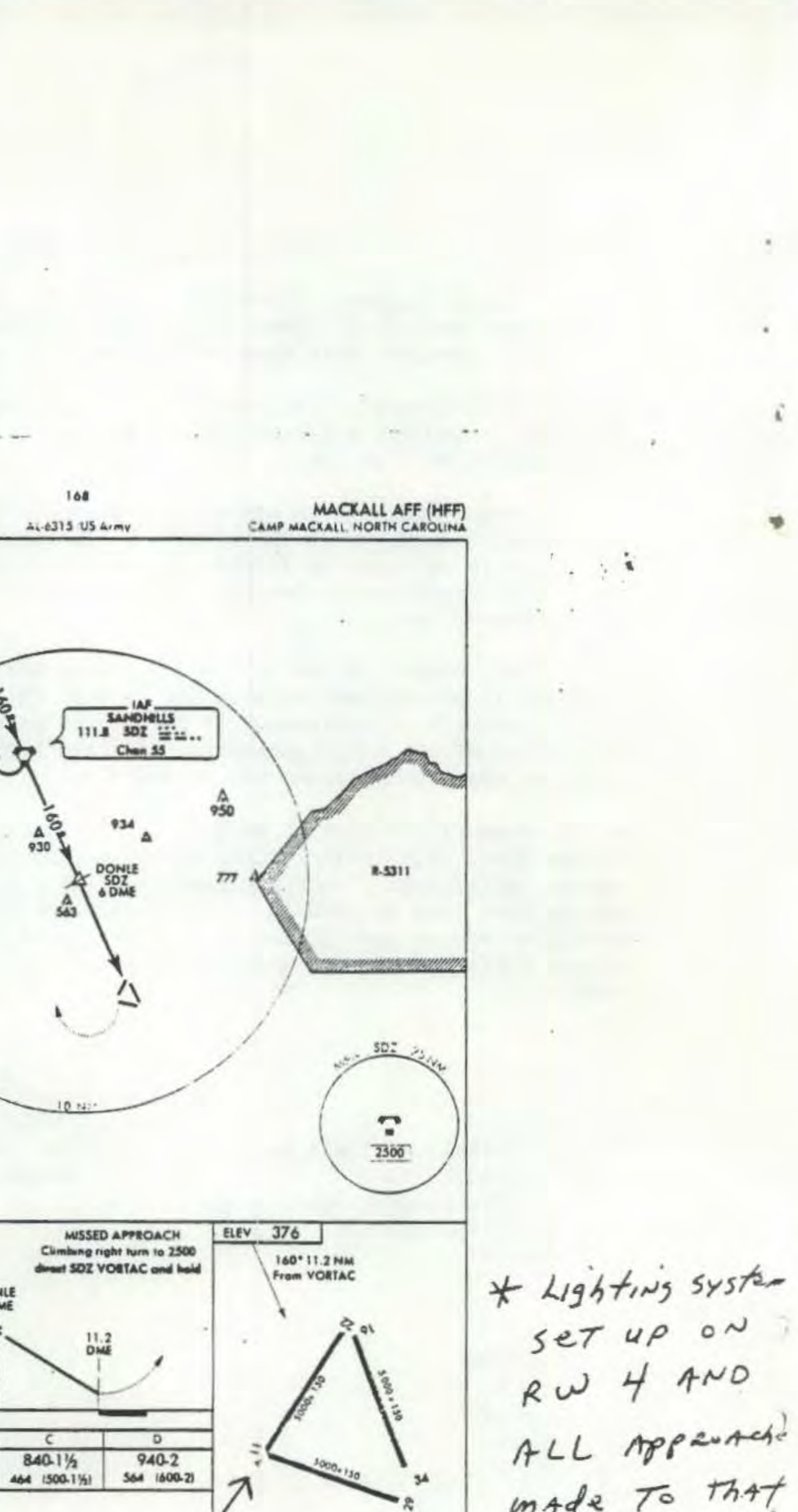
TEST DATA FOR ALL TESTS

TEST 41: (Altitude 1800'; 11ghts 18" above ground)

Trained eye acquired lights at 4.5 miles.

TEST 12: (Alt1tude 2000')

Trained eye acquited 11ghts at 6.0 miles; identifled at 4.5 miles.

Untrained eye acquired 3.5 miles; identified 3.5 .

TEST \#3: (Alt1tude 2500')

Trained eye acquired 6.0 miles; identified 4.0 .

Untrained eye acquired 5.25 miles; Identified 4.0 .

Untrained eye acquired 5.0 miles; identified 4.0 .

* No signif1cant improvement on ralsed 11ghts.

\section{TEST \#4: (Alt1tude 3000')}

Trained eye acquired 11ghts at 5.5 miles; identified 3.5.

Untrained eye acquired 11ghts at 5.5 miles; identified 3.5 .

Untra1ned eye acquired lights at 5.5 miles; 1dentified 3.5 .

All acquired runway edge 11ghts at 2.5 mlles.

\section{TEST \#5: (Alt1tude 2700')}

Trained eye acquired lights at 5.5 miles; 1dentified 3.5 .

Untralned eye acquired lights at 5.0 miles; identified 3.5 .

Untrained eye acquired lights at 5.0 miles; 1dentified 3.5 .

TEST \#6: (Altitude 3000')

Trained eye acquired 11ghts at 5.5 miles; 1dentifled 4.5.

Untained eye acquired lights at 5.5 miles, identified 4.5.

Untrained eye acquired lights at 5.5 miles, identfied 4.5

* 1st row of lights appeared dimmer.

2nd \& 3 rd rows of 11 ghts appeared brighter.

Helghts of lights were $18^{\prime \prime}, 36^{\prime \prime}$, and $60^{\prime \prime}$. Overall acquisition appeared to slightly increase. Lights appeared to be stacked optically at 4.5 miles. 
TEST \#7: (Alt1tude 3000')

Trained eye acquired lights at 5.5 miles; identified 3.5 .

Trained eye acquired lights at 5.5 miles; identified 3.5 .

Untrained eye acquired lights at 4.5 miles; identified 3.0 .

Untrained eye acquired lights at 5.0 miles; 1dentified 3.0

trained eyes acquired runway edge lights at 2.5 miles.

untrained eyes acquired runway edge lights at 1.5 miles.

TEST \#8: (Plan E) (Altitude 2500')

trained eyes acquired lights at 6 miles; identified at 4.5.

untrained eyes acquired 11ghts at 4.5 miles; 1dentified at 3.5 .

TEST \#9: (Plan F) (Altitude 2500')

trained eye acquired 11ghts at 6 miles.

untrained eye acquired 11 ghts at 5.5 miles.

untrained eye acquired lights at 5.0 miles.

All eyes identified at 3.5 miles at $2100^{\prime}$.

At 3.5 miles 3 rd set of lights were noted visually as being raised. 


\section{LIST OF ATTENDEES/PARTICIPANTS}

7-8 SEPTEMBER 1983

Mr. B111 Remint

Mr. Ne11 Case

Mr. Tom Hardy

LTC Les Everett

CPT James B. Stokes

CPT L.A. Mauro

CW3 Bob Wehrenbers

Mr. George Jensen

Mr. Andy Thompkins

Mr. Tom Anderson

Mr. G. Grandy 


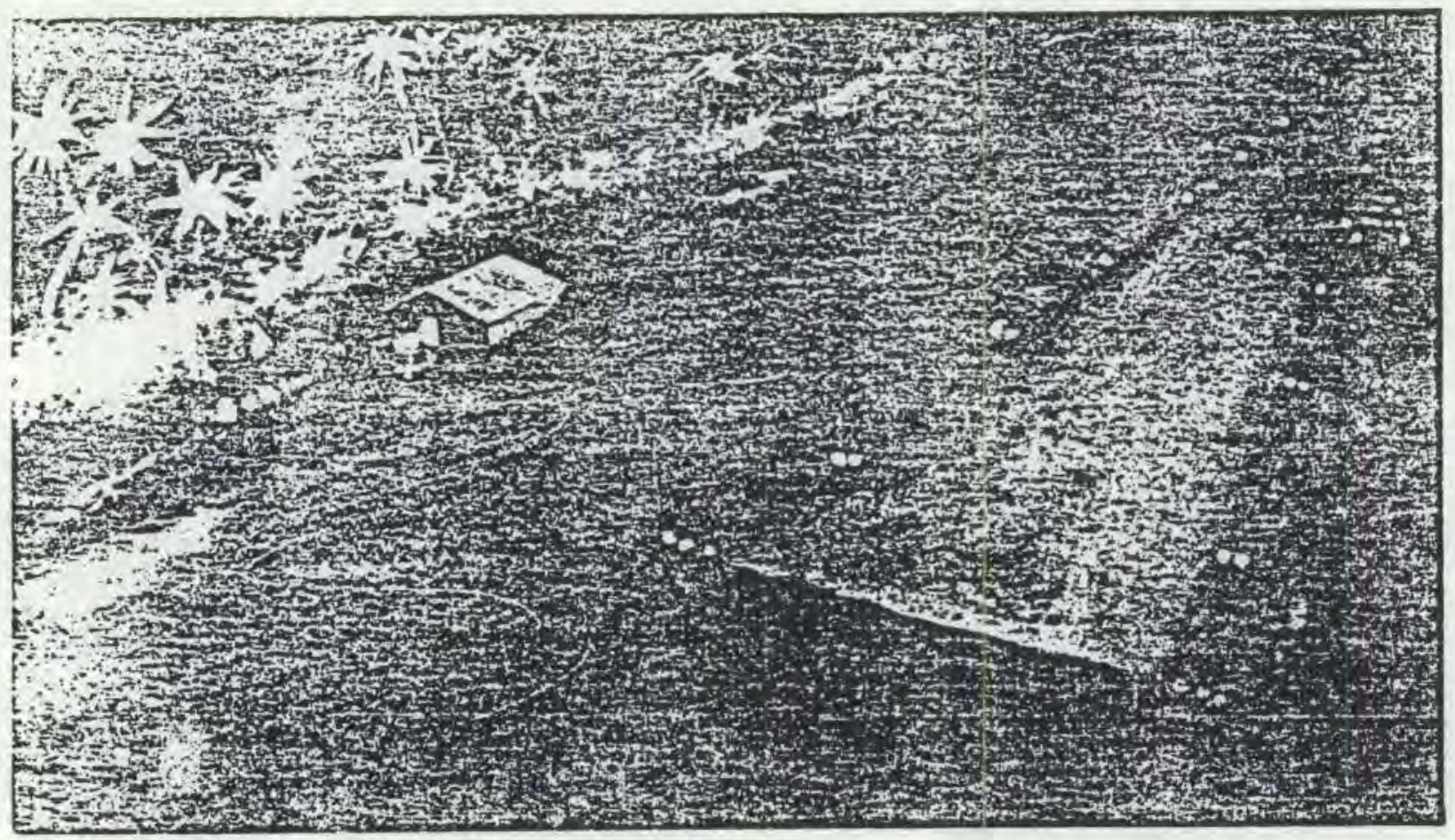

Six green lights define the end of the

usable runway. The lights are placed at

each corner and are spaced six feet apart.

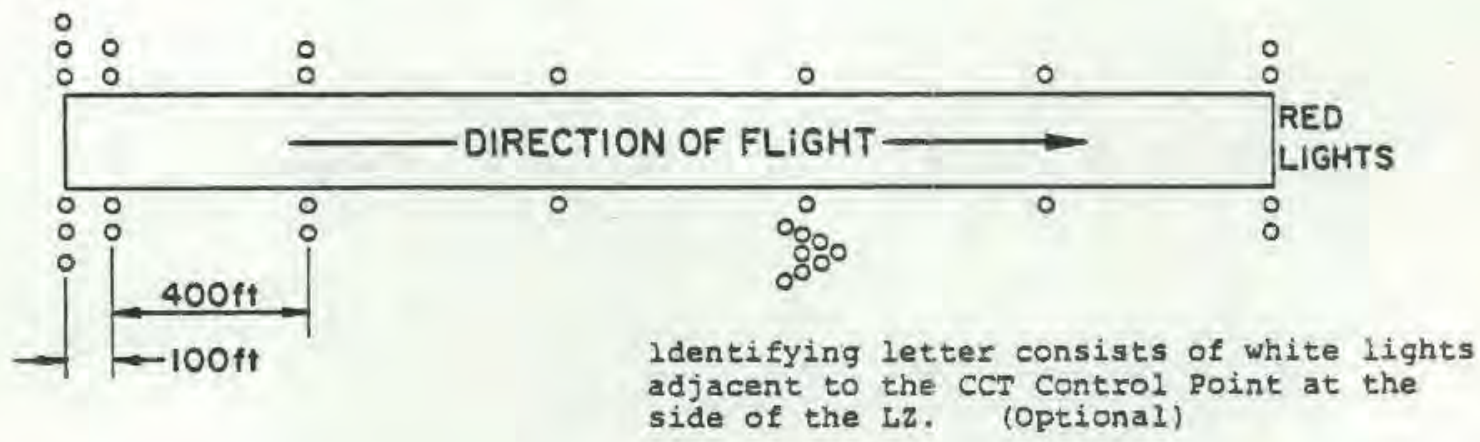

First white lights are dual and 100 feet down from the approach end of usable runway. The second white lights are dual and 400 feet down from the first. All subsequent white lights are single and 500 feet apart.

\section{NOTE}

All obstructions are marked with red lights. All taxiways and loading areas are marked with blue lights.

Figure 5-5. Landing Zone Markings (Night). 


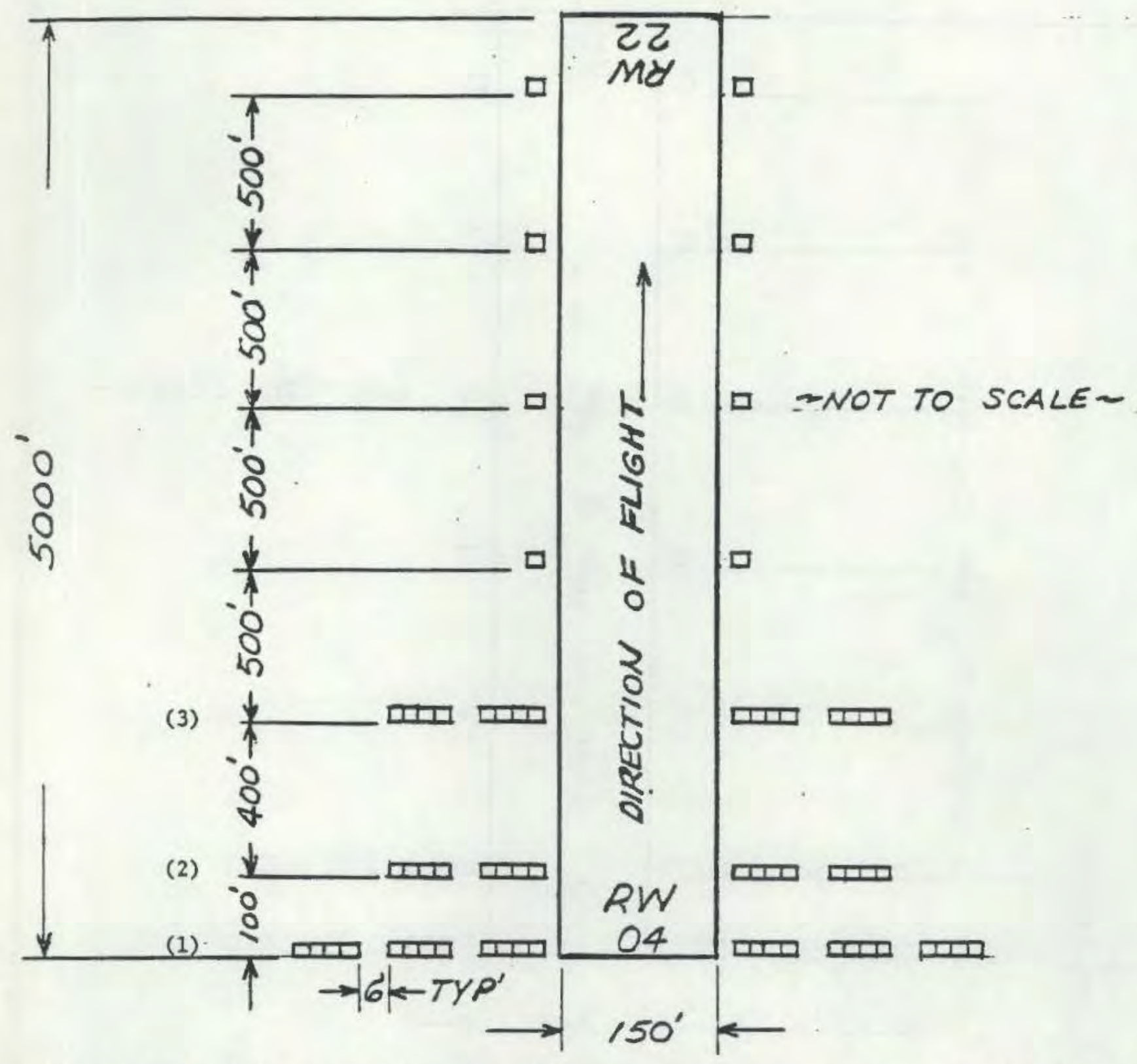

Each set of lights in the threshold and landing zone system contains 4 each 12 " $x 12$ " fixtures containing 7 tritium lights each fixture $=28$ tubes per set of lights. Tubes were mounted vertically for all tests.

TEST \#2:. Edge lights were added every $250^{\prime}$ with no significant improvement.

TEST \#3: Lights in Row \#3 were raised $2^{\prime}$ with no significant improvement.

TEST \#6: Lights in Row \#2 \& \#3 raised. Changes noted in configuration and overall acquisition appeared to slightly increase. Height of 3 sets 18", 36", 60". Lights appeared to be stacked optically. 


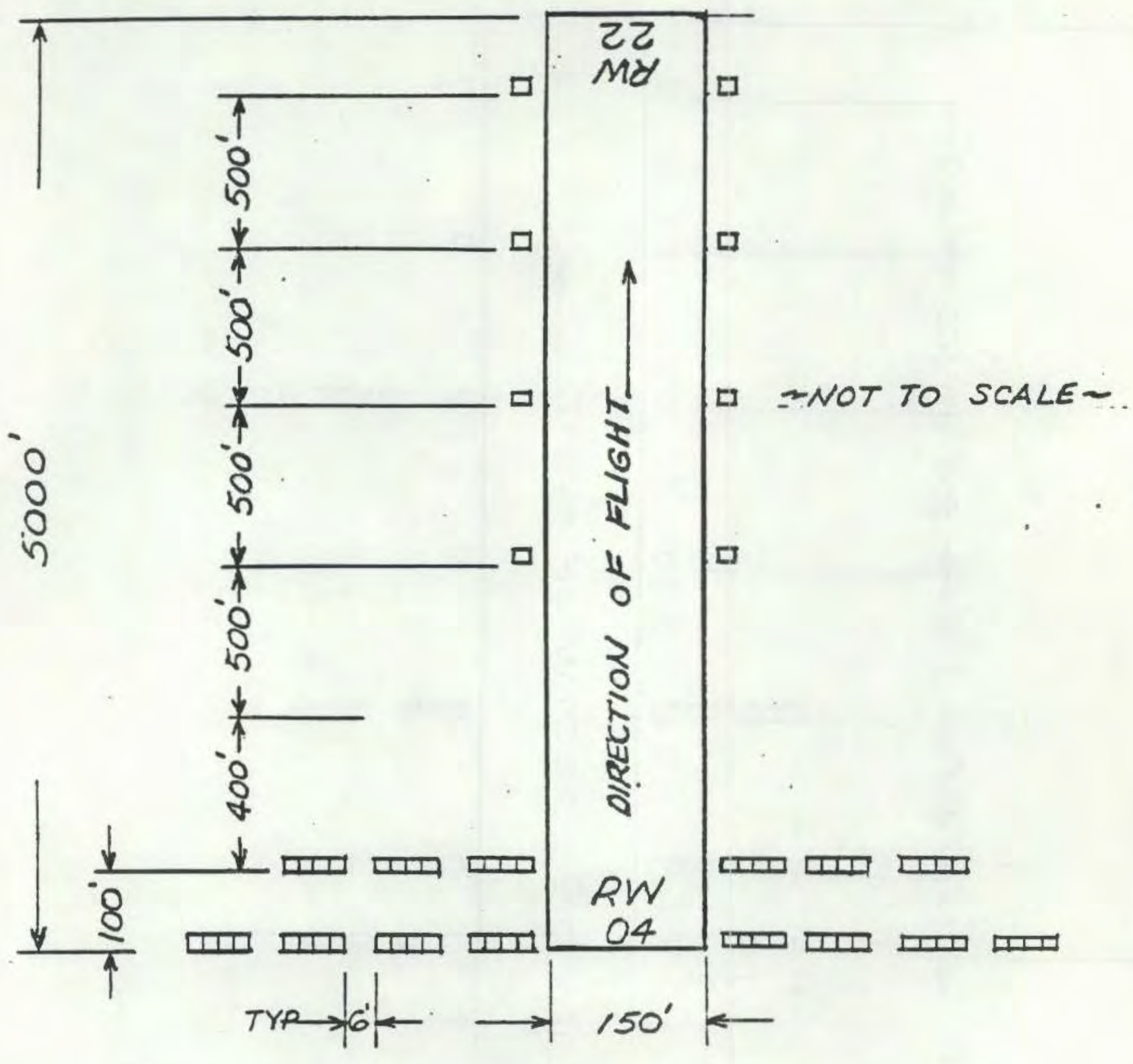

Light sets ( 4 fixtures each set) were moved from the far end of the landing zone and divided between the bottom end of the landing zone and the threshold lights. See Incl 非 for results. 


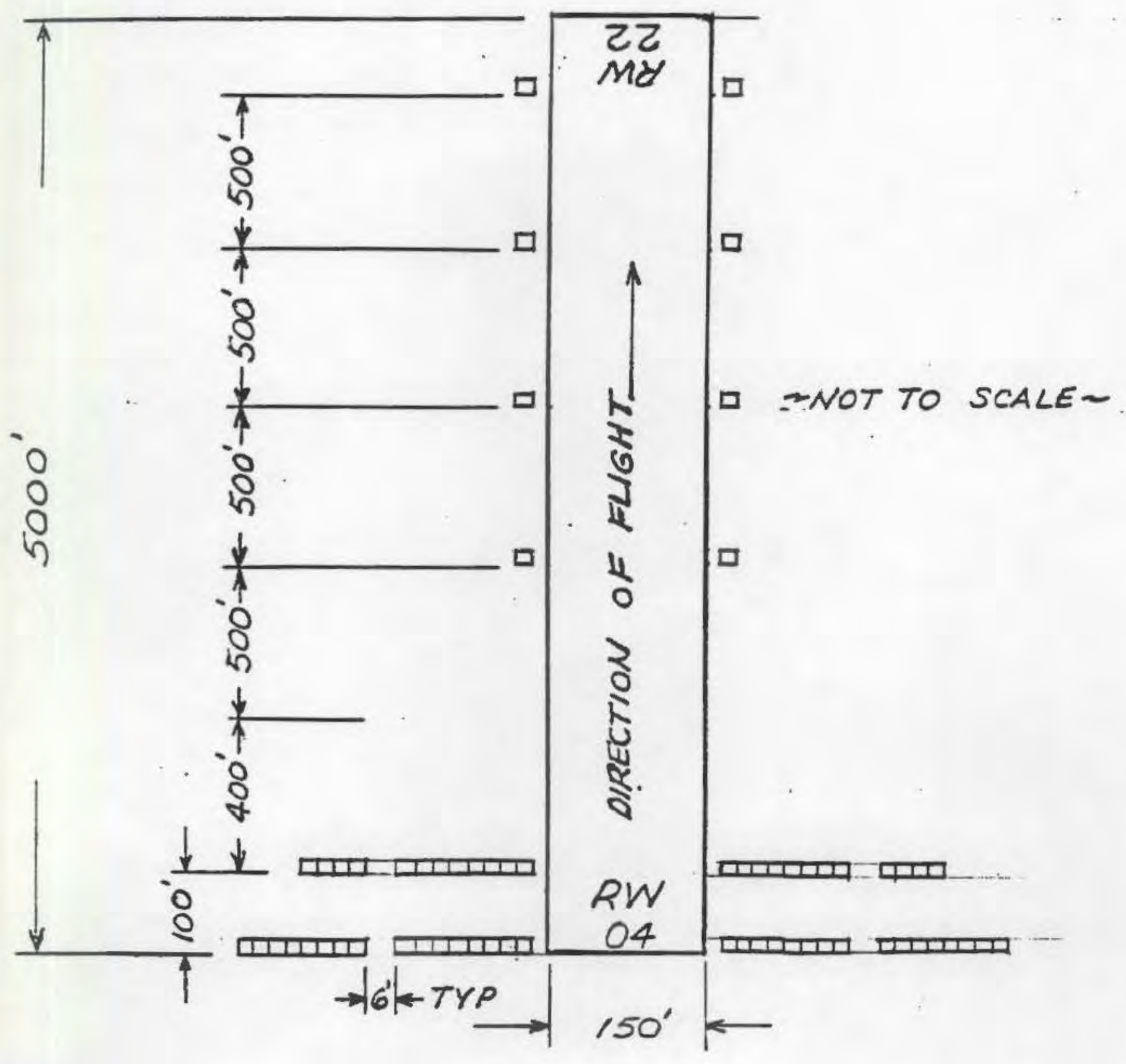

Light sets were moved closer together as depicted to "mass" more lights - see Test \#9 results on Incl $\# 2$. 



\section{DISTRIBUTION}

No. of

Copies

OFFSITE

2 DOE Technical Information Center

ONSITE

2 DOE Richland Operations Office

M. Dayani

H. E. Ransom

2 Battelle Alaska Operations

L. D. Perrigo

37 Pacific Northwest Laboratory

C. R. Hann

P. E. Hart

G. A. Jensen (25)

J. M. Latkovich

J. L. McElroy

G. L. Tingey

Publishing Coordination (2)

Technical Information (5) 
